DAVID CHRISTIAN REGIS PEREIRA GRUBBA

\title{
ESTUDO DO COMPORTAMENTO MECÂNICO DE UM AGREGADO RECICLADO DE CONCRETO PARA UTILIZAÇÃO NA CONSTRUÇÃO RODOVIÁRIA
}

\begin{abstract}
Dissertação apresentada à Escola de Engenharia de São Carlos, da Universidade de São Paulo, como parte dos requisitos para obtenção do Título de Mestre em Engenharia Civil: Transportes
\end{abstract}

Orientador: Prof. Tit. Alexandre Benetti Parreira 
AUTORIZO A REPRODUÇÃO E DIVULGAÇÃO TOTAL OU PARCIAL DESTE TRABALHO, POR QUALQUER MEIO CONVENCIONAL OU ELETRÔNICO, PARA FINS DE ESTUDO E PESQUISA, DESDE QUE CITADA A FONTE.

Ficha catalográfica preparada pela Seção de Tratamento da Informação do Serviço de Biblioteca - EESC/USP

Grubba, David Christian Regis Pereira
Estudo do comportamento mecânico de um agregado
reciclado de concreto para utilização na construção
rodoviária / David Christian Regis Pereira Grubba;
orientador Alexandre Benetti Parreira. -- São Carlos,
2009.
Dissertação (Mestrado-Programa de Pós-Graduação em
Engenharia de Transportes e Área de Concentração em
Infra-Estrutura de Transportes -- Escola de Engenharia de
São Carlos da Universidade de São Paulo, 2009.
1. Resíduos de construção e demolição. 2. Agregados
reciclados de concreto. 3. Módulo de resiliência.
4. Pavimentos. 5. Meio ambiente. I. Título.


FOLHA DE JULGAMENTO

Candidato: Engenheiro DAVID CHRISTIAN REGIS PEREIRA GRUBBA.

Dissertação defendida e julgada em 25/09/2009 perante a Comissão Julgadora:

Alx B Parvira

APROVADO

Prof. Titular ALEXANDRE BENETTI PARREIRA (Orientador) (Escola de Engenharia de São Carlos/USP)

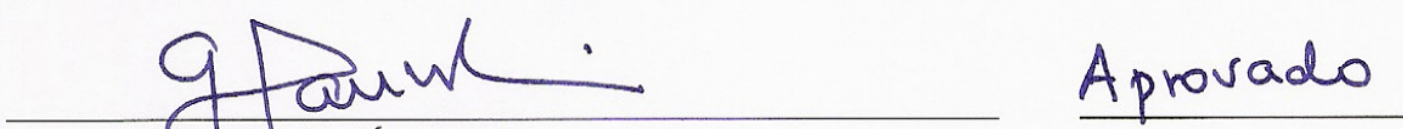

Prof. Dr. GLAAUCO TÚLIO PESSA FABBRI (Escola de Engenharia de São Carlos/USP)

Lauva Maricu Goretti da /Nota

Aprovado Prof. Dria LAURA MARIA GORETTI DA MO
(Universidade Federal do Rio de Janeiro/UFRJ)

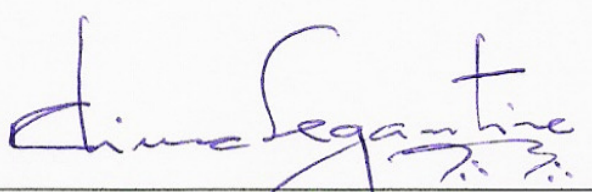

Prof. Associado PAULO/CESAR LIMA SEGANTINE

Coordenador do Programa de Pós-Graduação em Engenharia de Pransportes

Prof. Titular GERALDO ROBERTO MARTINS DA COSTA Presidente da Comissão da Pós-Graduação da EESC 



\section{DEDICATÓRIA}

\section{"Deus de promessas"}

Ministério Apascentar de Nova Iguaçu

(Davi Sacer, Verônica Sacer e Ronald Fonseca)

"Sei que os teus olhos

Sempre atentos permanecem em mim

E os teus ouvidos

Estão sensíveis para ouvir meu clamor

Posso até chorar...

Mas a alegria vem de manhã

És Deus de perto e não de longe

Nunca mudaste, tu és fiel

Deus de aliança, Deus de promessas

Deus que não é homem pra mentir

Tudo pode passar, tudo pode mudar

Mas tua palavra vai se cumprir

Posso enfrentar o que for

Eu sei quem luta por mim

Seus planos não podem ser frustrados

Minha esperança está

Nas mãos do grande Eu sou

Meus olhos vão ver o impossível

Acontecer..."

Dedico este trabalho à minha mãe, Maria

Lygia Rodrigues Pereira. 


\section{AGRADECIMENTOS}

Ao Senhor Jesus Cristo por escrever o meu nome no Livro da Vida e por me ajudar em todos os momentos, sem Ele nada seria possível.

À minha família, em especial à minha mãe, Maria Lygia, pela ajuda incondicional e pelo seu amor altruísta, ao meu irmão, Marcelo, por ser um presente de Deus, aos meus tios, Dena, Mita e Aloísio, e a minha avó, Lygia, pelo carinho.

À Paula, pelo seu amor, companheirismo e amizade. À sua família, Eliéte, Jair e Guilherme, que passaram a ser a minha segunda família, pela amizade e ajuda.

Ao Pastor Nelson e à irmã Solange, da Igreja Presbiteriana Renovada, pelo amor e orações, que me fortaleceram e me edificaram.

Ao Dr. Verzola pelo exemplo de caráter, seriedade e competência.

Ao meu orientador, Prof. Alexandre Benetti Parreira, pelos ensinamentos, apoio, conselhos, críticas, elogios e, em especial, pela confiança depositada no desenvolvimento deste trabalho.

Ao Prof. José Leomar Fernandes Júnior pelos ensinamentos durante o Programa de Aperfeiçoamento de Ensino (PAE), pelo incentivo e, principalmente, pela amizade sincera demonstrada em diversas ocasiões através de palavras e atos.

Ao Prof. Glauco Túlio Pessa Fabbri pelas diversas contribuições feitas durante a elaboração deste trabalho

Aos demais professores do Departamento de Transportes da Escola de Engenharia de São Carlos - USP pelos conhecimentos transmitidos.

Aos funcionários do Laboratório de Estradas, João, Paulo e Gigante pela participação na execução dos ensaios desta pesquisa e também por alguns conselhos.

Aos secretários do Departamento de Transportes, Alexandre, Heloísa, Beth, pela constante atenção e cordialidade e a Magali pelas palavras sempre amorosas. 
Aos meus amigos Alex, Wallace, Francis, Hellem, Rodrigo, Candido, Mauro, entre outros, pelas contribuições e pela amizade. Em especial, a dois grandes amigos, Walter e Sérgio, pelo apoio constante e pela agradável convivência, marcada por "leves" discussões e por muitos momentos divertidos.

À Usina de Reciclagem de Resíduos de Construção Civil de São Carlos Secretaria de Progresso e Habitação (PROHAB), nas figuras do Eng. Samir Costa Fagury e do encarregado Dirceu, pela disponibilização do agregado reciclado de concreto empregado para o desenvolvimento desta pesquisa e, também, a Pedreira Bandeirantes pelo fornecimento do agregado natural.

À Coordenadoria de Aperfeiçoamento de Pessoal de Ensino Superior (CAPES) pela bolsa de mestrado.

Aos que me ajudaram durante a minha faculdade na Universidade Federal de Juiz de Fora. Aos meus amigos de engenharia, Flávio, Tiago, Thiago, Paulo, Daniel e Eduardo, pela amizade que vamos levar para o resto da vida. Aos professores Alfredo Chaobach, Antônio de Pádua Pascini e Marcos Guerra, com os quais tive o prazer de trabalhar durante a faculdade. Em especial, ao Prof. Geraldo Luciano de Oliveira Marques pela orientação na iniciação científica e pela amizade.

Por fim, aos que me deram condições de ingressar na faculdade, Dra. Vera Amaral, Dr. Tarcísio Delgado e Colégio Cave pela concessão da bolsa de estudos integral para o terceiro ano do ensino médio. 


\section{RESUMO}

GRUBBA, D. C. R. P., Estudo do comportamento mecânico de um agregado reciclado de concreto para utilização na construção rodoviária. 139p. Dissertação (Mestrado) Escola de Engenharia de São Carlos, Universidade de São Paulo. 2009.

Os resíduos de construção e demolição $(R C D)$ representam cerca da metade dos resíduos sólidos urbanos. No Brasil, sua geração anual corresponde a aproximadamente 68 milhões de toneladas. Uma forma de se mitigar os impactos ambientais oriundos da disposição desses resíduos sobre o meio ambiente é o seu beneficiamento na forma de agregados reciclados. Os agregados reciclados podem ser classificados em dois grupos, agregados reciclados mistos e agregados reciclados de concreto (ARC). Entre as diversas formas de aplicação dos agregados reciclados, destaca-se a construção rodoviária por utilizar quantidade expressiva tanto de materiais graúdos, quanto de miúdos. No Brasil, ainda existem poucos relatos científicos sobre o desempenho de agregados reciclados de concreto em camadas de pavimentos. Assim, o objetivo desta pesquisa é estudar as propriedades físicas e o comportamento mecânico, através da análise de resultados de ensaios laboratoriais, do agregado reciclado de concreto proveniente da Usina de Reciclagem de Resíduos da Construção Civil de São Carlos-SP, visando seu emprego em camadas de base e sub-base de pavimentos. Foram realizados ensaios de caracterização física, lixiviação, solubilização, compactação, Índice de Suporte Califórnia (CBR), compressão simples, compressão diametral e triaxial cíclico. A título de comparação, foram pesquisados, também, um agregado natural, um solo de comportamento laterítico e uma mistura deste solo com o agregado reciclado de concreto. Observou-se que o ARC apresentou um comportamento mecânico muito próximo ao do agregado natural, material convencionalmente utilizado em camadas de pavimento na região. Destaca-se ainda que o agregado reciclado de concreto apresentou um ganho considerável de resistência e rigidez com o decorrer do tempo de cura. No tocante à energia de compactação, este parâmetro teve influência significativa sobre o comportamento do ARC para os tempos iniciais de cura, sendo que para os maiores períodos de cura, essa influência diminuiu. Finalmente, com base na avaliação dos resultados obtidos nesta pesquisa, concluiu-se que o agregado reciclado de concreto pode ser empregado na construção de camadas de sub-base e base de pavimentos.

Palavras Chaves: Resíduos de Construção e Demolição, Agregados Reciclados de Concreto, Módulo de Resiliência, Pavimentos e Meio Ambiente. 


\section{ABSTRACT}

GRUBBA, D. C. R. P., Study of the mechanical behavior of a recycled concrete aggregate for use in the road construction. 139p. Master's thesis. - Escola de Engenharia de São Carlos, Universidade de São Paulo. 2009.

The construction and demolition wastes (C \& D) represent about half of municipal solid wastes. There are estimative that, In Brazil, are produced approximately 68 million tons annually. One way to reduce the environmental impacts caused by theirs disposal is processing to obtain recycled aggregates. The recycled aggregate can be classified into two groups according their composition: mixed recycled aggregates and recycled concrete aggregates (RCA). Among different forms of application, roadway construction deserves prominence because of its singular characteristic to use considerable amounts or materials. In Brazil, there are few researches about behavior of recycled concrete aggregate in pavement layers. Thus, the objective of this research is to study the physical and mechanical behavior of recycled concrete aggregate (RCA) from São Carlos - SP, in order to investigate its utilization in base and subbase pavements layers. The laboratorial tests included in this research were physical characterization, leaching, dissolution, moisture-density relationships, California Bearing Ration (CBR), unconfined compressive strength, diametral compression and cyclic loading triaxial tests. Even, tests were conducted to compare the behavior of a natural aggregate, a lateritic soil and a mixture of this soil with the recycled concrete aggregate. It was observed that the RCA had similar mechanical behavior when compared to natural aggregate, material usually used in pavements layers of highways around São Carlos. Besides, the recycled concrete aggregate showed a considerable gain in strength and stiffness over time. About the energy compaction, this parameter had significant influence on RCA behavior for initial curing and decreased for the more periods of curing. Finally, based on evaluation of research results it was concluded that the RCA can be used in construction of base and subbase of pavements layers.

Key words: Construction and Demolition Wastes, Recycled Concrete Aggregate, Resilient Modulus, Pavements e Environment. 


\section{SUMÁRIO}

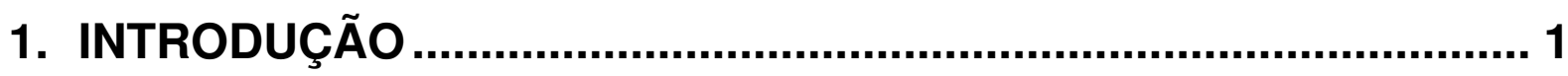

1.1. OBJETIVO

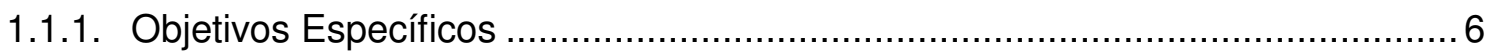

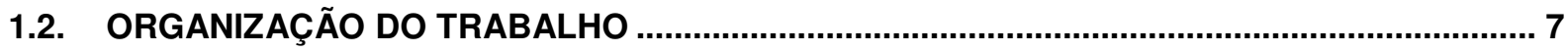

2. REVISÃO BIBLIOGRÁFICA ....................................................... 8

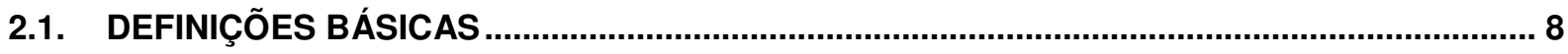

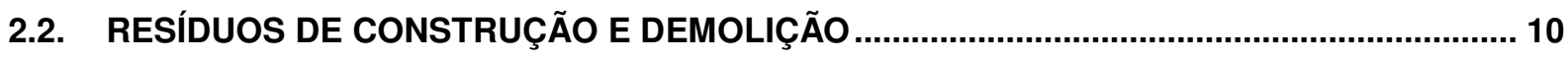

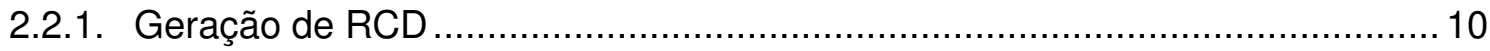

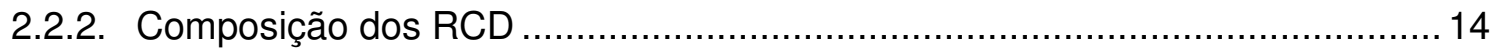

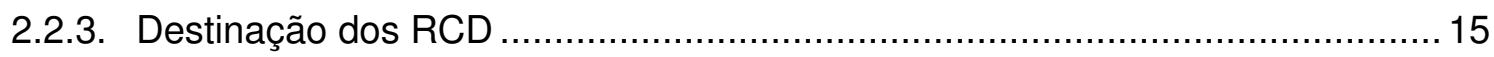

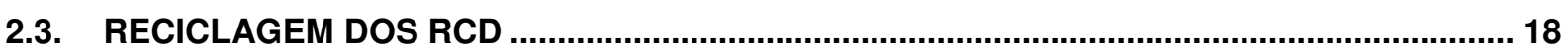

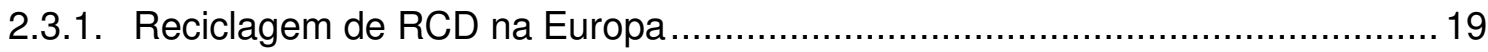

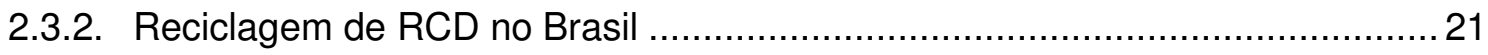

2.3.3. Aplicações de Agregados Reciclados de RCD ........................................ 24

2.4. EMPREGO DE AGREGADOS RECICLADOS DE RCD EM PAVIMENTAÇÃO ..................... 24

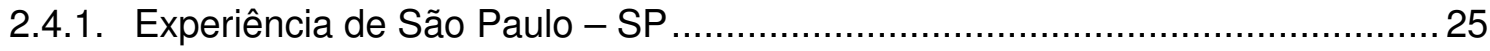

2.4.2. Experiência de Belo Horizonte - MG ....................................................... 27

2.4.3. Pista experimental de Goiânia - GO................................................ 28

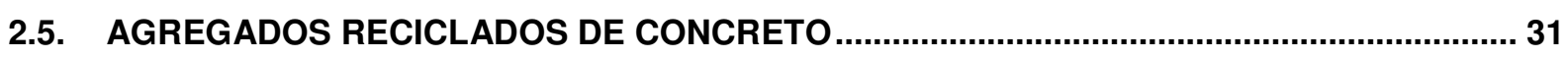

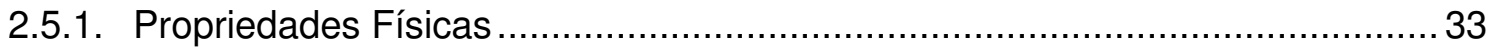

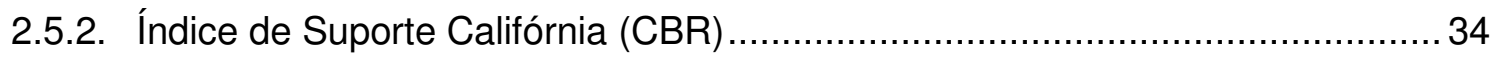

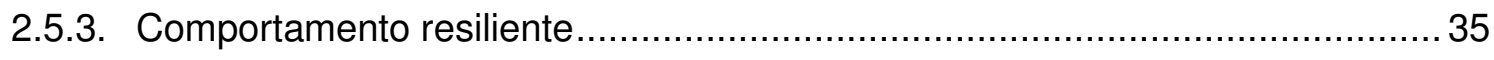

2.5.4. Efeito da cimentação própria ............................................................ 39 


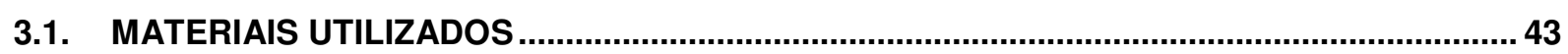

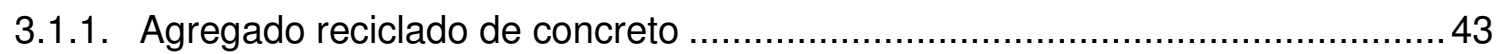

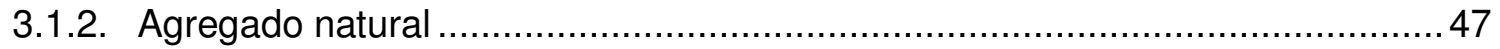

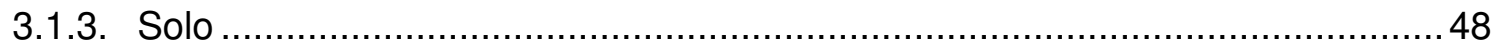

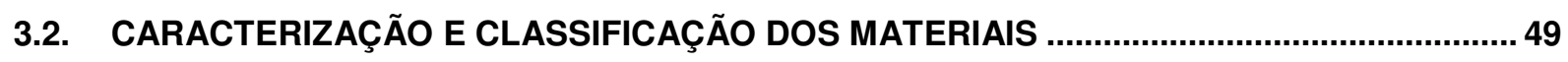

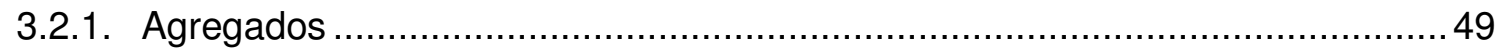

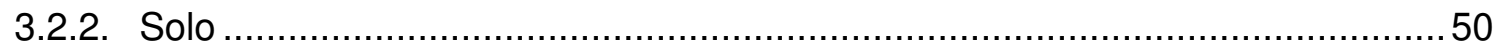

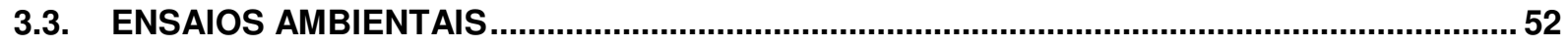

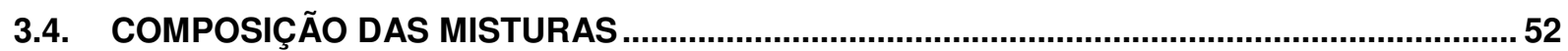

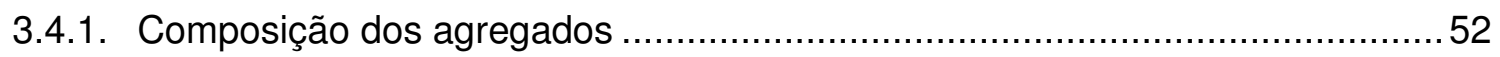

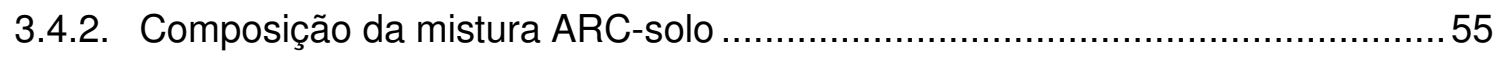

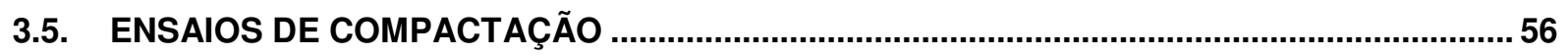

3.6. DEGRADAÇÃO DO AGREGADO RECICLADO DE CONCRETO ….......................................57

3.7. ENSAIOS DE CBR E DE COMPORTAMENTO MECÂNICO …...........................................57

3.7.1. Ensaio de Índice de Suporte Califórnia (CBR) …....................................... 57

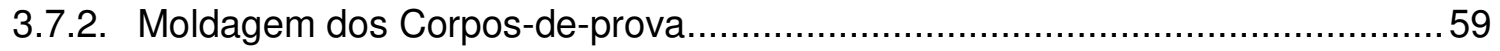

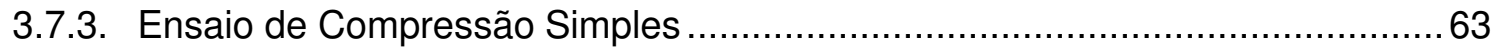

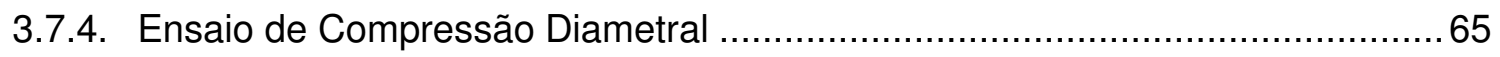

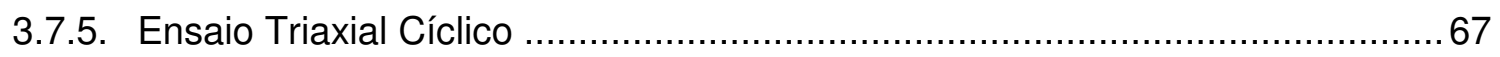

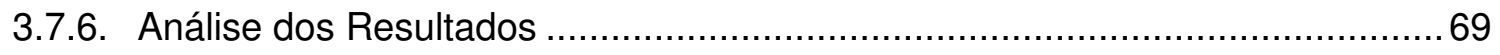

4. APRESENTAÇÃO E ANÁLISE DOS RESULTADOS.................... 71

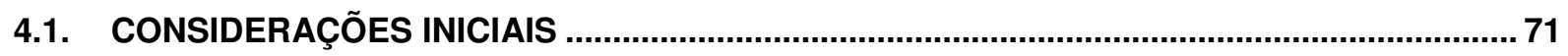

4.2. CARACTERIZAÇÃO FÍSICA DOS AGREGADOS

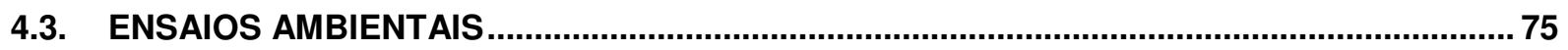

4.4. ENSAIOS DE COMPACTAÇÃO 
4.4.1. Desvio de umidade versus grau de compactação.

4.4.2. Resumo dos resultados dos ensaios de compactação

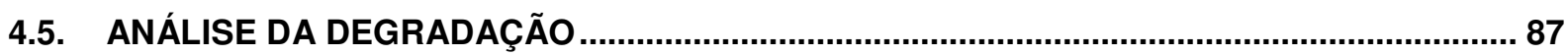

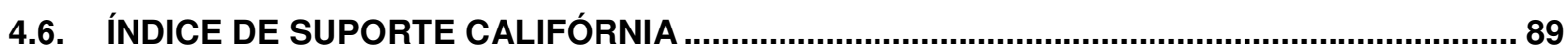

4.6.1. Análise da Influência da Energia de Compactação no CBR do ARC ...............92

4.6.2. Análise da Influência da Adição de Solo nos Valores de CBR ......................... 93

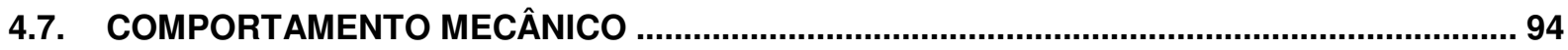

4.7.1. Ensaio de Compressão Simples .......................................................... 94

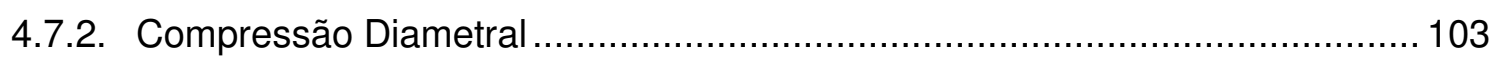

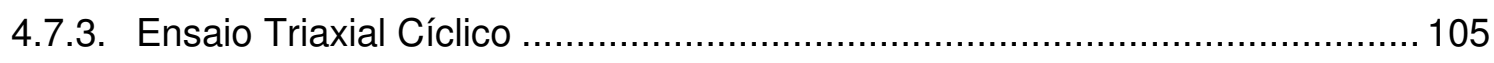

5. CONCLUSÕES ................................................................. 121

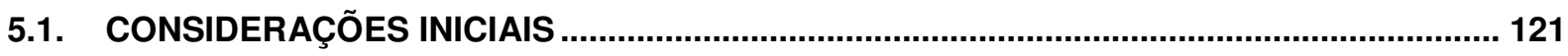

5.2. CARACTERIZAÇÃO, CLASSIFICAÇÃO AMBIENTAL E COMPACTAÇÃO........................121

5.3. DESEMPENHO DOS MATERIAIS COMPACTADOS NA ENERGIA MODIFICADA, ENSAIADOS SEM CURA

5.4. AVALIAÇÃO DO TEMPO DE CURA E DA ENERGIA DE COMPACTAÇÃO SOBRE O DESEMPENHO DO ARC

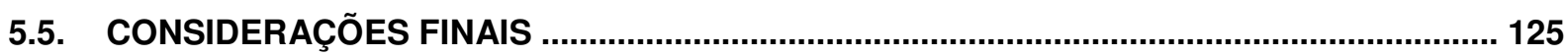

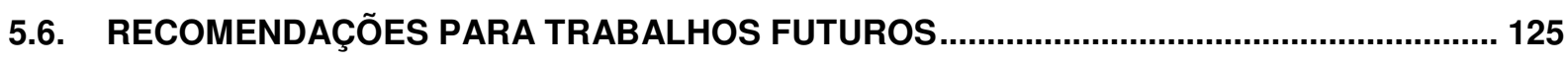

REFERÊNCIAS BIBLIOGRÁFICAS ............................................. 127

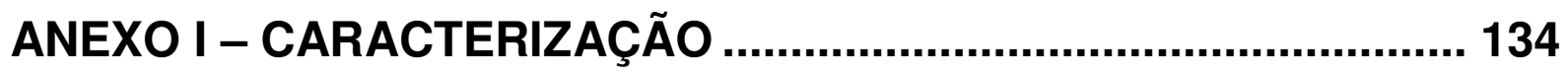

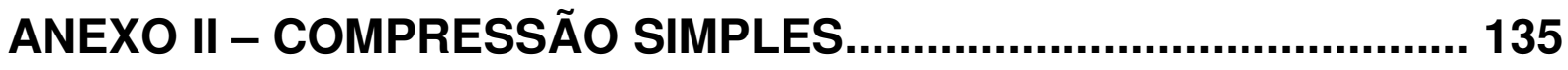

ANEXO III - COMPRESSÃO DIAMETRAL .................................... 138 


\section{LISTA DE FIGURAS}

Figura 2.1 - Composição média dos RCD de Salvador-BA (CARNEIRO et al., 2001).........14

Figura 2.2 - Disposição irregular de RCD próximo à Usina de Reciclagem de Resíduos da Construção Civil de São Carlos.

Figura 2.3 - Local de descarte clandestino na Avenida da Integração junto ao córrego da Água Quente - São Carlos-SP (MARQUES, 2005).

Figura 2.4 - Unidades de reciclagem de entulho de Belo Horizonte (CATAPRETA et al., 2008).

Figura 2.5 - Emprego de agregados reciclados de RCD em Belo Horizonte.

Figura 2.6 - Corte de um pavimento executado com base de agregados reciclados de RCD em Belo Horizonte (PINTO, 1999).

Figura 2.7 - Detalhes construtivos da execução da pista experimental de Goiânia (OLIVEIRA, 2007). 30

Figura 2.8 - Utilização de ARC em camadas de base e sub-base de pavimentos nos EUA (FHWA, 2004).

Figura 2.9 - Avaliação do CBR do ARC de Nova York (PETRARCA; GALDIERO, 1984). 35

Figura 2.10 - Módulo de resiliência de agregados de Nova Jersey (BENNERT et. al., 2000).

Figura 2.11 - Resultados de RCS do ARC (BLANKENAGEL, 2005).

Figura 2.12 - Módulos de resiliência de agregados reciclados de concreto para tempos de cura de 1 e 60 dias (ARM, 2001)...

Figura 2.13 - Módulos de resiliência de agregados naturais para 1 e 90 dias de cura (ARM, 2001).

Figura 2.14 - Comparação do MR do agregado natural com os do ARC (ARM, 2001).

Figura 3.1 - Seqüência de algumas atividades realizadas na Usina de Reciclagem de Resíduos de Construção Civil de São Carlos-SP (FAGURY; GRANDE, 2007).

Figura 3.2 - Pilhas de agregado reciclado de concreto.

Figura 3.3 - Distribuições granulométricas das três graduações de ARC.

Figura 3.4 - Distribuições granulométricas das duas graduações de agregado natural. 48

Figura 3.5 - Distribuição granulométrica do solo. 
Figura 3.6 - Resultado da classificação MCT para o solo pesquisado. 51

Figura 3.7 - Distribuições granulométricas das misturas proporcionadas............................. 54

Figura 3.8 - Distribuição granulométrica da mistura ARC-solo. .......................................... 56

Figura 3.9 - Compactação de corpos-de-prova de CBR ...................................................... 58

Figura 3.10 - Imersão de corpos-de-prova de CBR........................................................... 58

Figura 3.11 - Prensa empregada para penetração dos corpos-de-prova de CBR. ................... 58

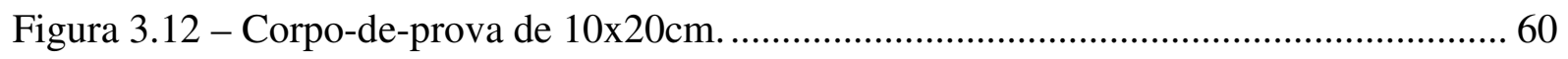

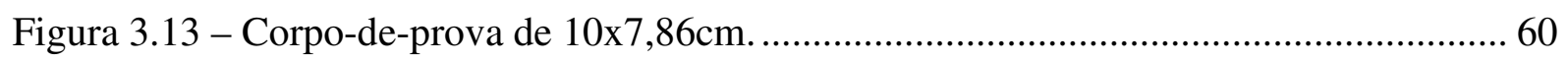

Figura 3.14 - Prensa empregada para moldagem dos corpos-de-prova. ................................ 61

Figura 3.15 - Cilindros empregados na moldagem dos corpos-de-prova de 10x20cm......... 61

Figura 3.16 - Cilindros empregados na moldagem dos corpos-de-prova de $10 \times 7,86 \mathrm{~cm}$....... 61

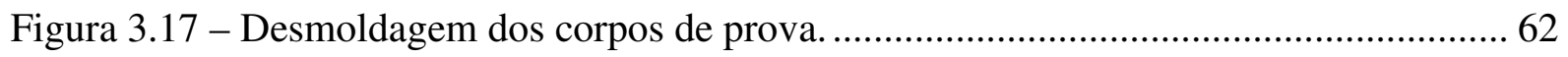

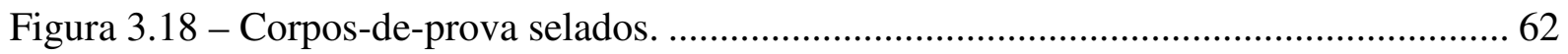

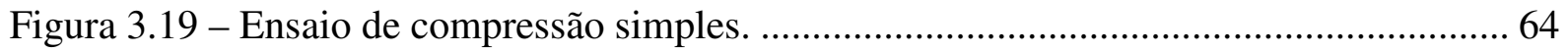

Figura 3.20 - Parâmetros avaliados no ensaio de compressão simples................................. 64

Figura 3.21 - Rompimento de um corpo-de-prova no ensaio de compressão diametral......... 65

Figura 3.22 - Prensa empregada no ensaio de compressão diametral.................................... 66

Figura 3.23 - Equipamento triaxial cíclico - Laboratório de Estradas da EESC/USP............ 68

Figura 3.24 - Detalhe da saída do programa de aquisição de dados do ensaio triaxial cíclico.

Figura 4.1 - Avaliação da presença de argamassa aderida aos grãos antes e depois do ensaio de abrasão Los Angeles.

Figura 4.2 - Curvas de compactação do ARC para as energias intermediária e modificada. . 78

Figura 4.3 - Curva de compactação solo (energia modificada)........................................... 81

Figura 4.4 - Curvas de compactação do ARC-solo e do ARC (energia modificada)............... 81

Figura 4.5 - Curva de compactação do agregado natural (energia modificada)...................... 82

Figura 4.6 - Grau de compactação versus desvio de umidade do ARC. ................................. 84

Figura 4.7 - Grau de compactação versus desvio de umidade do ARC e do ARC-solo. ......... 85 
Figura 4.8 - Grau de compactação versus desvio de umidade do ARC e do agregado natural.

Figura 4.9 - Degradação do agregado reciclado de concreto. 88

Figura 4.10 - Variação do CBR do ARC e do agregado natural em função do teor de umidade.

Figura 4.11 - Exemplos de curva tensão-deformação obtida de RCS do ARC e do solo........94

Figura 4.12 - Aspectos de corpos-de-prova do ARC e do solo. ...........................................95

Figura 4.13 - RCS dos materiais compactados na energia modificada..................................96

Figura 4.14 - Módulo tangente dos materiais compactados na energia modificada...............97

Figura 4.15 - Variação da RCS do agregado reciclado de concreto ao longo do tempo.........99

Figura 4.16 - Variação do módulo tangente do ARC ao longo do tempo de cura..................101

Figura 4.17 - Evolução da resistência à tração do ARC ao longo tempo. .............................. 104

Figura 4.18 - Representação tridimensional do modelo composto para o agregado natural. 109

Figura 4.19 - Representação tridimensional do modelo composto para ARC com 0 dia de cura e compactado na energia intermediária. .............................................................. 109

Figura 4.20 - Representação tridimensional do modelo composto para ARC com 0 dia de cura e compactado na energia modificada............................................................ 110

Figura 4.21 - Representação tridimensional do modelo composto para ARC com 90 dia de cura e compactado na energia intermediária.

Figura 4.22 - Representação tridimensional do modelo composto para ARC com 90 dia de cura e compactado na energia modificada.....

Figura 4.23 - Representação tridimensional do modelo composto para ARC-solo com 0 dia de cura e compactado na energia modificada...................................................... 111

Figura 4.24 - Representação tridimensional do modelo composto para solo com 0 dia de cura e compactado na energia modificada.............................................................. 112

Figura 4.25 - Variação do MR com a tensão confinante para os materiais granulares compactados na energia modificada.......................................................... 114

Figura 4.26 - Variação do MR do ARC com a tensão confinante. ....................................... 115

Figura 4.27 - Estrutura do pavimento hipotético considerada na análise do MR................. 117

Figura 4.28 - MR dos materiais compactados na energia modificada................................ 118

Figura 4.29 - MR dos agregados reciclados de concreto para os tempos de cura de 0 e 90 dias. 


\section{LISTA DE TABELAS}

Tabela 2.1 - Geração de RCD em alguns países membros da União Européia (EC, 2000)... 11

Tabela 2.2 - Estimativa da geração de RCD em alguns municípios paulistas (SINDUSCONSP, 2005).

Tabela 2.3 - Porcentagem reutilizada ou reciclada de RCD em alguns países membros da União Européia (SYMONDS, 1999).

Tabela 2.4 - Custo unitário de execução de bases e sub-bases de pavimentos. Fonte: Tabela de custos unitários PMSP - Julho de 2008 (PMSP, 2008).

Tabela 2.5 - Características da pista experimental de Goiânia (Adaptado de Mendes et al., 2004).

Tabela 2.6 - Resumo das deflexões características e admissíveis da pista experimental de Goiânia (OLIVEIRA, 2007).

Tabela 2.7 - Abrasão Los Angeles de agregados reciclados de concreto. .34

Tabela 3.1 - Resultados dos ensaios de massa específica dos grãos e limites de liquidez. .....50

Tabela 3.2 - Aspectos normativos referentes à granulometria de agregados reciclados (NBR 15115).

Tabela 3.3 - Distribuições granulométricas das misturas proporcionadas..............................54

Tabela 3.4 - Parâmetros obtidos da distribuição granulométrica do ARC. …..........................55

Tabela 3.5 - Tensões empregadas no ensaio triaxial cíclico (AASHTO T 307-99)................68

Tabela 4.1 - Características físicas dos agregados......................................................... 71

Tabela 4.2 - Comparação de resultados de abrasão Los Angeles de agregados reciclados de concreto com agregados reciclados mistos........................................................ 74

Tabela 4.3 - Resultados do ensaio de lixiviação do agregado reciclado de concreto...............75

Tabela 4.4 - Resultados do ensaio de solubilização do agregado reciclado de concreto..........75

Tabela 4.5 - Resultados de solubilização acima dos prescritos por norma de um solo do interior paulista (SILVA JÚNIOR, 2009). ................................................... 77

Tabela 4.6 - Umidade ótima e massa específica seca máxima dos ARC. .............................. 79

Tabela 4.7 - Quadro resumo dos resultados dos ensaios de compactação.............................. 87

Tabela 4.8 - Degradação do agregado reciclado de concreto. ............................................. 87 
Tabela 4.9 - Limites de CBR e expansão preconizados pela norma NBR 15115.

Tabela 4.10 - Resultados de CBR do ARC - energia modificada ....................................... 91

Tabela 4.11 - Resultados de CBR do ARC - energia intermediária ..................................... 92

Tabela 4.12 - Resultados de CBR e expansão obtidos para o ARC-solo e para o solo........... 93

Tabela 4.13 - Resistência e rigidez imediata dos materiais pesquisados. ............................. 96

Tabela 4.14 - Resultados de compressão simples do agregado reciclado de concreto ........... 98

Tabela 4.15 - Resultados de módulo tangente à 50\% da tensão de ruptura do agregado

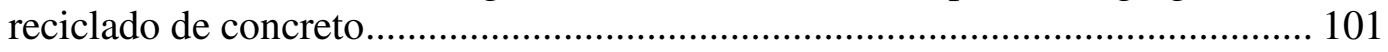

Tabela 4.16 - Resultados de resistência à tração por compressão diametral imediata........... 103

Tabela 4.17 - Evolução da resistência à tração do ARC ao longo do tempo. ....................... 104

Tabela 4.18 - Constantes de regressão e $\mathrm{R}^{2}$ para o agregado reciclado de concreto.............. 107

Tabela 4.19 - Constantes de regressão e $\mathrm{R}^{2}$ para o ARC-solo, solo e agregado natural. ...... 107

Tabela 4.20 - Características da estrutura do pavimento hipotético.................................... 117

Tabela 4.21 - Valores de MR calculados para o centro da camada de base da estrutura proposta. 


\section{LISTA DE ABREVIATURAS E SIGLAS}

AASHTO American Association of State Highway and Transportation Officials

ABNT Associação Brasileira de Normas Técnicas

ARC Agregado(s) Reciclado(s) de Concreto

c' Coeficiente de deformabilidade da classificação MCT

CBR California Bearing Ratio

CONAMA Conselho Nacional de Meio Ambiente

DNER Departamento Nacional de Estradas de Rodagem

DNIT Departamento Nacional de Infra-Estruturas de Transportes

e' I Índice da classificação MCT

EC European Commission

EESC Escola de Engenharia de São Carlos

EPA Environment Protection Agency

FHWA Federal Highway Administration U.S. Department of Transportation

GC Grau de Compactação

HRB Highway Research Board

ISC Índice de Suporte Califórnia

LG' Solo argiloso de comportamento laterítico

MCT Miniatura Compactado Tropical

MCV Moisture Condition Value

MR Módulo de Resiliência

NBR Norma Brasileira Registrada

PMBH Prefeitura Municipal de Belo Horizonte 


\begin{tabular}{|c|c|}
\hline PMSP & Prefeitura Municipal de São Paulo \\
\hline $\mathrm{RCD}$ & Resíduos de Construção e Demolição \\
\hline RCS & Resistência à Compressão Simples \\
\hline RTCD & Resistência à Tração por Compressão Diametral \\
\hline TRB & Transportation Research Board \\
\hline USP & Universidade de São Paulo \\
\hline$\Delta \sigma$ & Desvio de tensão \\
\hline$\Delta \omega$ & Desvio de umidade \\
\hline$\varepsilon$ & Deformação \\
\hline$\theta$ & Tensão volumétrica ou Primeiro invariante de tensões \\
\hline$\rho_{\mathrm{d}}$ & Massa específica seca \\
\hline$\rho_{\mathrm{d}, \text { máx }}$ & Massa específica seca máxima \\
\hline$\omega$ & Teor de umidade \\
\hline$\omega_{\text {ót. }}$ & Teor de umidade Ótima \\
\hline$\tau$ & Tensão cisalhante \\
\hline$\sigma_{1}$ & Tensão principal maior \\
\hline$\sigma_{3}$ & Tensão principal menor \\
\hline$\sigma_{\mathrm{c}}$ & Tensão confinante \\
\hline$\sigma_{\mathrm{d}}$ & Tensão desvio \\
\hline
\end{tabular}




\section{INTRODUÇÃO}

O setor de construção civil é de grande importância estratégica para qualquer país, principalmente para os em desenvolvimento, como o Brasil, onde este se destaca no processo de crescimento econômico e na redução de desemprego, dada sua capacidade de gerar vagas diretas e indiretas no mercado de trabalho. Entretanto, observa-se que esse setor provoca significativos impactos ambientais, sendo um grande consumidor de recursos naturais e gerador de resíduos.

Os resíduos da construção e demolição (RCD), comumente chamados de entulho ou caliça, são aqueles provenientes de construções, reformas, reparos e demolições de obras de construção civil, e os resultantes da preparação e da escavação de terrenos (CONAMA, 2002). Geralmente, esses resíduos são considerados como sendo inertes e pertencentes à classe de resíduos sólidos urbanos.

De acordo com Rao et al (2007), os resíduos de construção e demolição constituem a maior porção, em massa, dos resíduos sólidos gerados no mundo. Estima-se que sejam geradas a cada ano cerca de 180 milhões de toneladas desses resíduos na União Européia (EC, 2000), 136 milhões nos EUA (EPA, 1998) e 68,5 milhões no Brasil (ANGULO, 2005). A deposição dessa imensa quantidade de 
material sobre o meio ambiente urbano tem causado diversos transtornos às sociedades.

No Brasil, os impactos acarretados por esses resíduos ainda são agravados pelo alto índice de descarte irregular. De acordo com o SINDUSCON-SP (2005), essa forma de descarte provoca a degradação das áreas de mananciais e de preservação permanente; o assoreamento de rios e córregos; a erosão de encostas; a proliferação de agentes transmissores de doenças; e a ocupação de vias, terrenos e praças por entulhos, com prejuízo à circulação de pessoas e veículos.

Além disso, os constantes alagamentos, observados durante os períodos chuvosos em cidades de médio e grande porte, como São Paulo, são provocados, em grande parte, pela obstrução dos sistemas de drenagem pelos resíduos sólidos urbanos, dentre os quais os RCD correspondem a cerca da metade. Nestas situações, a água sem ter por onde escoar deixa ruas intransitáveis, provocando muitas vezes acidentes, invade residências e contribui para a deterioração precoce dos pavimentos urbanos.

A deposição dos resíduos de construção e demolição em aterros sanitários também não é uma alternativa adequada. Essa forma de gestão dos RCD contribui de forma significativa para o constante esgotamento destes locais. Observa-se ainda que áreas próprias para a construção de novos aterros estão localizadas cada vez mais distantes dos centros urbanos, acarretando um acréscimo nos custos de transporte de resíduos. Analisando-se de forma crítica, chega a ser um contra-senso 
ocupar espaço destinado a resíduos não recicláveis com um material com um alto potencial de reciclagem.

Assim, com o propósito de minimizar os impactos ambientais provocados pela construção civil, com base em critérios de desenvolvimento sustentável, diversos países, como Holanda, Bélgica, França, Estados Unidos e Japão, estão investindo em pesquisas que visam à quantificação e a reciclagem dos resíduos de construção e demolição. As sociedades e os governantes dessas nações têm despertado para o fato de que o desenvolvimento deve ser alcançado de forma sustentável, isto é, que o atendimento das necessidades da geração atual não pode impossibilitar que as gerações futuras atendam suas próprias necessidades.

A reciclagem dos resíduos de construção e demolição, além de minimizar os impactos gerados por sua deposição sobre o meio ambiente, permite que uma quantidade significativa de materiais possa ser reutilizada de forma racional (EC, 2000), transformando um produto, antes descartado, em uma matéria prima de qualidade.

Os RCD podem ser reciclados na forma de agregados reciclados através de um beneficiamento, constituído basicamente de operações de triagem, britagem e peneiramento. Geralmente, os agregados reciclados são classificados, de acordo com sua constituição predominante, em dois grupos: agregados reciclados de concreto e agregados reciclados mistos. 
Os agregados reciclados de concreto (ARC), considerados como mais nobres e homogêneos do que os mistos, apresentam em sua constituição mais de $90 \%$ de resíduos de concreto, argamassa e materiais pétreos. Esses agregados podem ser empregados em diversas aplicações, como por exemplo, na confecção de argamassas, elementos pré-moldados de concreto e calçadas. Na pavimentação, os ARC podem ser utilizados tanto na massa asfáltica dos pavimentos flexíveis quanto no concreto dos pavimentos rígidos, contudo sua destinação mais usual é para construção de camadas de sub-base e base.

Nos Estados Unidos, o aproveitamento de agregados reciclados de concreto em pavimentação é bem intenso. De acordo com FHWA (2004), dos 50 estados norte-americanos, 38 já empregam esse tipo de agregado para construção de camadas de base e sub-base de pavimentos. Estima-se que $85 \%$ de todos os resíduos de concreto que são reciclados são utilizados com esta finalidade (WILBURN; GOONAN, 1998).

Os agregados reciclados de concreto apresentam um excelente comportamento mecânico. De acordo com Saeed et al(2007), o Índice de Suporte Califórnia (CBR) deste tipo de agregado varia de $94 \%$ a $184 \%$. O seu módulo de resiliência é similar ao dos agregados naturais e em alguns casos, como relatado por Bennert et. al. (2000), chega a ser até superior. Outro aspecto interessante, observado em algumas pesquisas internacionais, é a melhoria de seu desempenho ao longo do tempo. 
Além disso, devido à substituição dos agregados convencionais por reciclados, sua utilização propicia a preservação de jazidas minerais, protegendo o meio ambiente. Em locais onde essas jazidas se encontram escassas ou distantes, seu emprego pode aumentar a disponibilidade de matéria-prima.

Em alguns casos, verifica-se que o custo do agregado reciclado é inferior ao dos agregados convencionais, acarretando uma diminuição dos custos decorrentes de obras de pavimentação. Assim, nestas circunstâncias, para um mesmo orçamento, poderia se construir uma maior extensão de vias pavimentadas.

No Brasil, o aumento da porcentagem de vias pavimentadas seria particularmente importante. Em 2005, de acordo com os indicadores de transporte rodoviário apresentados em COPPEAD (2007), havia 1.413.982 quilômetros de trechos não pavimentados, representando aproximadamente $88 \%$ da malha rodoviária brasileira. Essa situação contribui para o alto índice de perda de produção e aumento do custo operacional dos veículos, sendo um obstáculo ao crescimento econômico brasileiro.

No ambiente urbano, também é observado que uma parcela significativa das vias ainda permanece sem pavimentação. Até mesmo na maior cidade do país, São Paulo, em 1998, havia ainda 2937 km de via públicas não pavimentadas, o que correspondia na época a quase de 18\% da malha existente (PMSP, 1998).

Por fim, acredita-se que o emprego de agregados reciclados de concreto na construção de camadas de sub-bases e bases de pavimentos pode ser uma 
alternativa interessante sob aspectos técnicos, ambientais, econômicos e sociais. Contudo, mesmo observando-se a grande carência de vias pavimentadas e os benefícios promissores relativos ao emprego desse material, sua utilização é pouco difundida no Brasil. Ressalta-se também, que ainda existem poucos relatos de pesquisas nacionais realizadas sobre o comportamento mecânico deste agregado reciclado.

\subsection{OBJETIVO}

Esta pesquisa tem como objetivo estudar as propriedades físicas e o comportamento mecânico, através da análise de resultados de ensaios laboratoriais, do agregado reciclado de concreto proveniente da Usina de Reciclagem de Resíduos da Construção Civil de São Carlos-SP, visando seu emprego em camadas de base e sub-base de pavimentos.

\subsubsection{Objetivos Específicos}

Caracterizar o agregado reciclado de concreto de São Carlos através de ensaios de peneiramento, abrasão Los Angeles, absorção e densidade aparente.

Avaliar o comportamento mecânico do agregado reciclado in natura e misturado a um solo através dos ensaios de índice de Suporte Califórnia, compressão simples, compressão diametral e triaxial cíclico. 
Analisar o efeito de cimentação própria do agregado reciclado de concreto ao longo do tempo através dos ensaios de compressão simples, compressão diametral e triaxial cíclico.

Avaliar a influência da energia de compactação no desempenho mecânico imediato e ao longo do tempo do agregado reciclado de concreto in natura.

Comparar os resultados de caracterização e de comportamento mecânico do agregado reciclado com o de um agregado natural, usualmente empregado em serviços de pavimentação.

\subsection{ORGANIZAÇÃO DO TRABALHO}

Esse texto está dividido em cinco capítulos. O primeiro apresenta uma breve justificativa sobre a relevância do tema, o objetivo do trabalho e como esse foi organizado. O segundo apresenta a pesquisa bibliográfica dos principais assuntos que dão suporte ao trabalho, tais como geração e reciclagem dos resíduos de construção e demolição, aplicações dos agregados reciclados de concretos e empregos destes materiais em camadas de bases e sub-bases de pavimentos. No terceiro, são descritos os materiais escolhidos, os procedimentos laboratoriais e as técnicas de análise de resultados utilizados para a realização desta pesquisa. No quarto, são apresentados e analisados os resultados laboratoriais. Por último, no quinto capítulo, são relatadas as principais conclusões obtidas nesta pesquisa e feitas algumas sugestões para trabalhos futuros. 


\section{REVISÃO BIBLIOGRÁFICA}

\subsection{DEFINIÇÕES BÁSICAS}

Resíduo, oriundo do termo em latim residuu, significa aquilo que sobra de qualquer substância. Este vocábulo passou a ser largamente utilizado pelos engenheiros sanitaristas em substituição ao termo lixo a partir da década de 1960 (MARQUES, 2005).

Os resíduos sólidos podem ser classificados com base em vários critérios. De acordo com sua origem, podem ser divididos em urbanos, industriais, de serviços de saúde e radioativos. Segundo o seu grau de degrabilidade, podem ser classificados em: a) facilmente degradáveis, como por exemplo, a matéria orgânica presente nos resíduos sólidos de origem urbana; b) moderadamente degradáveis, tais como papéis e papelão; c) dificilmente degradáveis, como borracha, madeira e pedaços de pano; d) não-degradáveis, incluem-se os metais, plásticos, pedras, entre outros. (BIDONE; POVINELLI, 1999).

A classificação proposta na NBR 10004 (ABNT, 2004a) considera a periculosidade dos resíduos sólidos e fornece procedimentos que viabilizam a identificação quanto aos riscos potenciais que esses oferecem ao meio ambiente e à saúde pública. Essa norma enquadra os resíduos em dois grupos: classe I - 
perigosos e classe II - não-perigosos. A classe II ainda é dividida em dois subgrupos: classe II A - não inertes e classe II B - inertes.

Os resíduos de construção e demolição (RCD) são aqueles provenientes de construções, reformas, reparos e demolições de obras de construção civil, e os resultantes da preparação e da escavação de terreno, comumente chamados de entulho ou caliça. Os RCD podem ser constituídos de diversos tipos de materiais, tais como: tijolos, blocos cerâmicos, telhas, concreto em geral, argamassa, solos, rochas, metais, entre outros (CONAMA, 2002). Esses resíduos são geralmente considerados como inertes e pertencentes à classe de resíduos sólidos urbanos.

A resolução do Conselho Nacional do Meio Ambiente Nº 307 (CONAMA, 2002) classifica os resíduos da construção civil em quatro classes, A, B, C e D, com base no seu potencial de reciclagem ou reuso. A classe A engloba os resíduos reutilizáveis ou recicláveis como agregados, tais como: tijolos, blocos, telhas, argamassa e concreto. A classe B incorpora os resíduos que são recicláveis, mas não para produção de agregados, como papel, plásticos, metais, vidros, madeiras, entre outros. A classe $C$ abrange os resíduos para os quais ainda não foram desenvolvidas tecnologias ou aplicações economicamente viáveis que permitam sua reciclagem, como exemplo, os produtos oriundos do gesso. Por último, a classe D é representada pelos resíduos perigosos, provenientes de processos construtivos. Os principais materiais contidos nesta classe são tintas, óleos, e aqueles originários de demolições e reparos de clínicas radiológicas, instalações industriais e outros. 
Agregados reciclados, segundo a norma NBR 15114 (ABNT, 2004d), são os materiais granulares provenientes do beneficiamento de resíduos de construção da classe A que apresentam características técnicas para a aplicação em obras de edificação, de infra-estrutura, de aterros sanitários ou outras obras de engenharia.

Os agregados reciclados são geralmente classificados em mistos e de concreto. Os agregados reciclados de concreto (ARC), de acordo com a norma NBR 15116 (ABNT, 2004f), são aqueles obtidos do beneficiamento de resíduos da construção civil da classe A, composto em sua fração graúda de no mínimo 90\%, em massa, de fragmentos à base de cimento Portland e rochas. Os agregados mistos são aqueles provenientes do beneficiamento de resíduos da construção civil da classe A que possuem menos de $90 \%$ de materiais cimentícios e rochas.

\subsection{RESÍDUOS DE CONSTRUÇÃO E DEMOLIÇÃO}

\subsubsection{Geração de RCD}

Os resíduos de construção e demolição constituem a maior porção em massa dos resíduos sólidos gerados no mundo (RAO et al., 2007). Em 1994, estimativas apontavam para uma geração mundial anual desses resíduos compreendida entre 2 e 3 bilhões de toneladas (LAURITZEN, 1994).

Nos Estados Unidos, estima-se que foram geradas mais de 136 milhões toneladas de resíduos de construção e demolição no ano de 1996, sendo que nesses cálculos não estão incluídos os materiais procedentes de obras rodoviárias e 
de escavações (EPA, 1998). Nesse país, a maior parte dos RCD gerada, cerca de $50 \%$, é proveniente do setor de demolição, em seguida, vem as atividades de manutenção e reformas que abrangem 40\%, e em último, o setor de novas construções que gera a menor parcela, aproximadamente 10\% (SANDLER, 2003).

$\mathrm{Na}$ União Européia, de acordo com o relatório "Management of Construction and Demolition Waste" publicado pela Comissão Européia, calculava-se, em 2000, que eram produzidas anualmente cerca de 180 milhões de toneladas de resíduos de construção e demolição (EC, 2000). A Tabela 2.1 mostra a taxa anual de geração de RCD em alguns países membros desse bloco econômico.

Tabela 2.1 - Geração de RCD em alguns países membros da União Européia (EC, 2000).

\begin{tabular}{cc}
\hline PAís & $\begin{array}{c}\text { GERAÇÃo DE RCD } \\
\text { (milhões de } \\
\text { ton./ano) }\end{array}$ \\
\hline Alemanha & 59 \\
Reino Unido & 30 \\
França & 24 \\
Itália & 20 \\
Espanha & 13 \\
Holanda & 11 \\
Bélgica & 7 \\
Áustria & 5 \\
Portugal & 3 \\
Dinamarca & 3 \\
Grécia & 2 \\
Suécia & 2 \\
Finlândia & 1 \\
Irlanda & 1 \\
\hline
\end{tabular}

Analisando-se a Tabela 2.1, observa-se que a geração anual de resíduos de construção e demolição varia consideravelmente nos países membros citados. A Alemanha apresenta a maior taxa de produção de RCD, 59 milhões de toneladas por ano, o que corresponde a quase 1/3 do total produzido na União Européia, enquanto a Finlândia, por exemplo, gera apenas um milhão de tonelada por ano. 
Essas diferenças são decorrentes de vários fatores, tais como técnicas construtivas, tamanho do país e população.

A disposição dos resíduos de construção e demolição é também um grave problema no continente asiático. Em Hong-Kong, somente em 2004, foram produzidas mais de 20 milhões de toneladas de RCD (POON et al, 2006). Acreditase que essa elevada produção seja devida ao fenômeno do "crescimento vertical" ocorrido nas últimas décadas. Esse fenômeno é bem comum em metrópoles, nas quais a falta de terrenos livres acarreta a demolição de muitas edificações antigas para a construção de edifícios altos.

No Brasil, não existem informações oficiais sobre a quantidade de resíduos proveniente dos setores de construção e demolição. Segundo Pinto (2001), há um profundo desconhecimento por parte dos administradores públicos quanto aos volumes gerados desses resíduos, dos impactos que esses causam e de seus custos sociais. Contudo, estima-se que os RCD representem cerca da metade dos resíduos sólidos urbanos (RSU) gerados no país, o que corresponde a uma produção anual aproximada de 68,5 milhões de toneladas (ANGULO, 2005).

No Estado de São Paulo, o setor de construção civil também é considerado como o principal gerador de resíduos sólidos urbanos. A Tabela 2.2 apresenta a quantidade de RCD produzida diariamente em alguns municípios paulistas e sua participação em relação ao total de resíduos sólidos urbanos. Analisando-se essa tabela, verifica-se que somente no município de São Paulo são produzidas em torno de 17 mil toneladas diariamente de RCD, o que corresponde a mais de 5,3 milhões 
de toneladas anualmente. Nesta tabela, é possível observar que em todas as cidades citadas a proporção dos resíduos de construção e demolição em relação ao total de resíduos sólidos urbanos é maior do que 50\%.

Tabela 2.2 - Estimativa da geração de RCD em alguns municípios paulistas (SINDUSCON-SP, 2005).

\begin{tabular}{cccc}
\hline MUNICÍPIO & $\begin{array}{c}\text { ANO DE } \\
\text { REFERÊNCIA }\end{array}$ & $\begin{array}{c}\text { GERAÇÃo } \\
\text { DIÁRIA (ton.) }\end{array}$ & $\begin{array}{c}\text { RCD/ RSU } \\
\text { (\%) }\end{array}$ \\
\hline São Paulo & 2003 & 17340 & 55 \\
Campinas & 1996 & 1800 & 64 \\
Guarulhos & 2001 & 1308 & 50 \\
Ribeirão Preto & 1995 & 1023 & 70 \\
Santo André & 1997 & 1013 & 54 \\
São José dos Campos & 1995 & 733 & 67 \\
São José do Rio Preto & 1997 & 687 & 58 \\
\hline
\end{tabular}

Além da geração inerente às atividades do setor de construção civil, as guerras e os desastres naturais produzem milhões de toneladas desses resíduos. A Segunda Guerra Mundial, por exemplo, gerou apenas na Alemanha um volume compreendido entre 400 e 600 milhões de metros cúbicos de entulhos (HANSEN, 1992).

Em Taiwan, a questão dos resíduos da construção e demolição recebeu uma atenção especial devido a um terremoto que atingiu o país em 21 de setembro de 1999. Segundo Huang et al. (2002), esse desastre provocou danos estruturais em mais de 100.000 edificações que necessitaram ser reformadas ou totalmente reconstruídas, resultando em mais de 30 milhões de toneladas de entulhos, apenas na região do epicentro. 


\subsubsection{Composição dos RCD}

A composição dos resíduos de construção é dependente das características específicas de cada região, como técnicas construtivas e matérias-primas disponíveis. No Brasil, a maior parte desses resíduos é composta por materiais inertes e recicláveis, como restos de argamassas, concretos, agregados pétreos e materiais cerâmicos.

A título de exemplificação, a Figura 2.1 apresenta a constituição dos RCD da cidade de Salvador-BA. De acordo com Carneiro et al. (2001), os resíduos de construção e demolição dessa cidade apresentam em sua composição $94 \%$ de materiais com alto potencial de reciclagem.

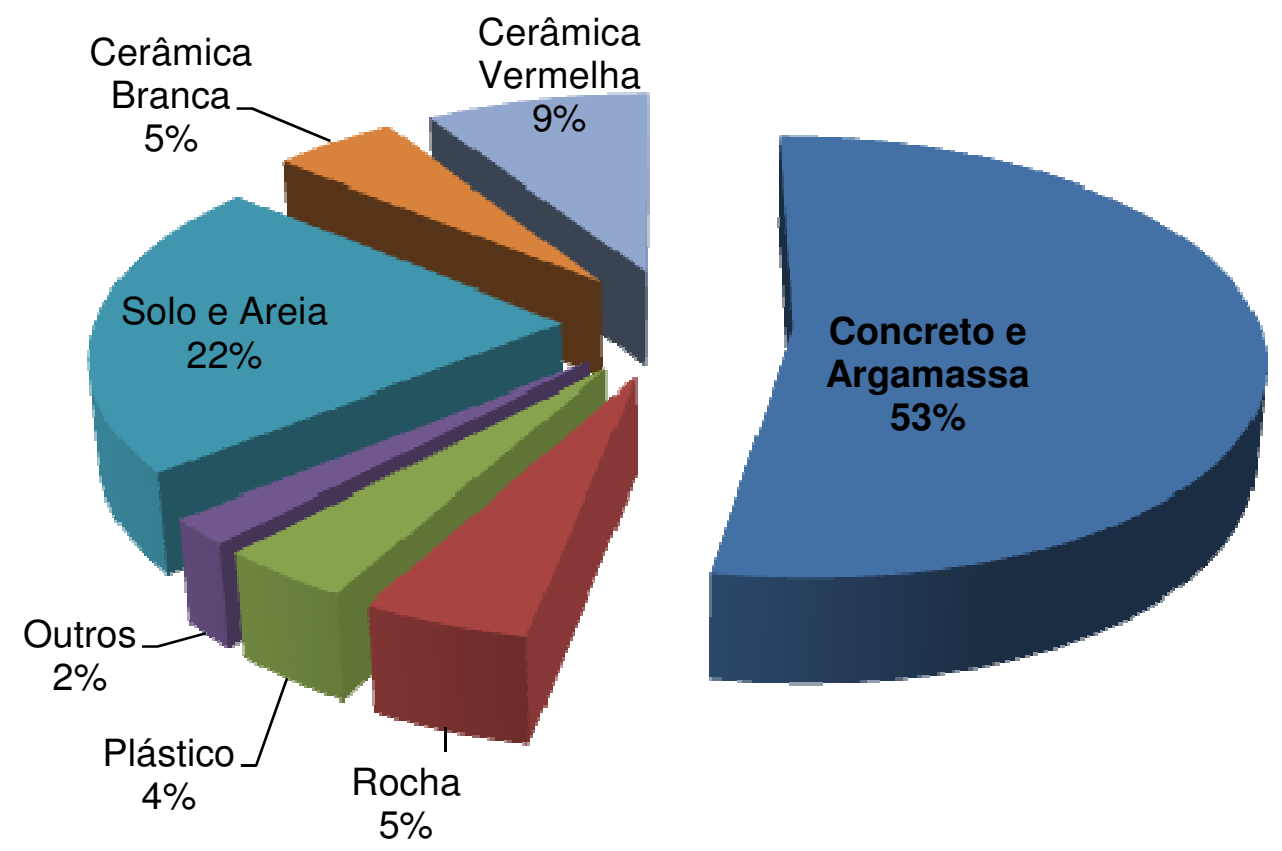

Figura 2.1 - Composição média dos RCD de Salvador-BA (CARNEIRO et al., 2001). 
Analisando-se a Figura 2.1, observa-se que a maior parte dos resíduos de construção e demolição da cidade de Salvador-BA era composta por resíduos de concreto e argamassa em 2001.

\subsubsection{Destinação dos RCD}

No Brasil, a disposição dos resíduos de construção e demolição deve atender a critérios específicos determinados segundo a Resolução no 307 do CONAMA (CONAMA, 2002). De acordo com essa resolução, a destinação dos RCD é de responsabilidade do gerador.

Ainda segundo essa resolução, os resíduos da construção civil não podem ser dispostos em aterros de resíduos domiciliares, em áreas de "bota fora", em encostas, corpos d’água, lotes vagos e em áreas protegidas por lei. Os RCD devem ser reutilizados ou reciclados na forma de agregados, ou encaminhados a áreas de aterro de resíduos da construção civil, sendo dispostos de modo a permitir a sua utilização ou reciclagem futura. Entretanto, de acordo com Pinto (2001), em nosso país, a deposição de grandes volumes de RCD é feita geralmente em "bota-foras".

A deposição dos resíduos de construção e demolição em aterros provoca o constante esgotamento desses locais, aumentando os gastos públicos com desapropriações necessárias para a criação de novas áreas destinadas ao armazenamento de resíduos. Verifica-se ainda que em cidades de médio e grande porte, as áreas próprias para a construção de aterros sanitários estão cada vez mais distantes dos centros urbanos, o que tem causado uma elevação dos custos de 
transporte dos resíduos. Essa situação contribui para que os gastos com limpeza pública absorvam uma parcela significativa dos orçamentos. De acordo com o Instituto de Pesquisas Tecnológicas (IPT, 2000), esses custos consomem de 7 a $15 \%$ dos orçamentos municipais, dos quais cerca de 50 a $70 \%$ são destinados somente à coleta e transporte dos resíduos.

Na União Européia, vários países membros vêm tomando medidas para restringir ou proibir a deposição de resíduos da construção e demolição em aterros sanitários, incentivando assim, sob o ponto de vista econômico a reciclagem. Em 1996, o Reino Unido introduziu uma tarifa sobre a deposição de resíduos inertes em aterro. Em primeiro de janeiro de 1997, a Holanda proibiu a deposição de RCD em aterros sanitários (EC, 2000).

No Brasil, a situação da gestão dos resíduos de construção e demolição é agravada pelos altos índices de disposição irregular desses materiais em vias públicas, terrenos baldios, praças, calhas de rios e encostas. Segundo SINDUSCON-SP (2005), essa forma de destinação dos RCD provoca diversos impactos ao meio ambiente e à sociedade, como a degradação das áreas de mananciais e de preservação permanente; a proliferação de agentes transmissores de doenças; o assoreamento de rios e córregos; a obstrução dos sistemas de drenagem; e a ocupação de vias e logradouros públicos por resíduos.

Observa-se que na maioria das cidades brasileiras existem diversos locais onde ocorrem disposição irregular de resíduos da construção e demolição. Em São Carlos-SP, por exemplo, a presença de entulhos é verificada até no acesso à Usina 
de Reciclagem de Resíduos da Construção Civil da cidade, conforme mostrado na Figura 2.2. Segundo Marques (2005), a maior parte das disposições irregulares desse município se concentra nas encostas dos córregos que cortam a cidade. A Figura 2.3 apresenta um flagrante de descarte clandestino de RCD junto a um córrego.

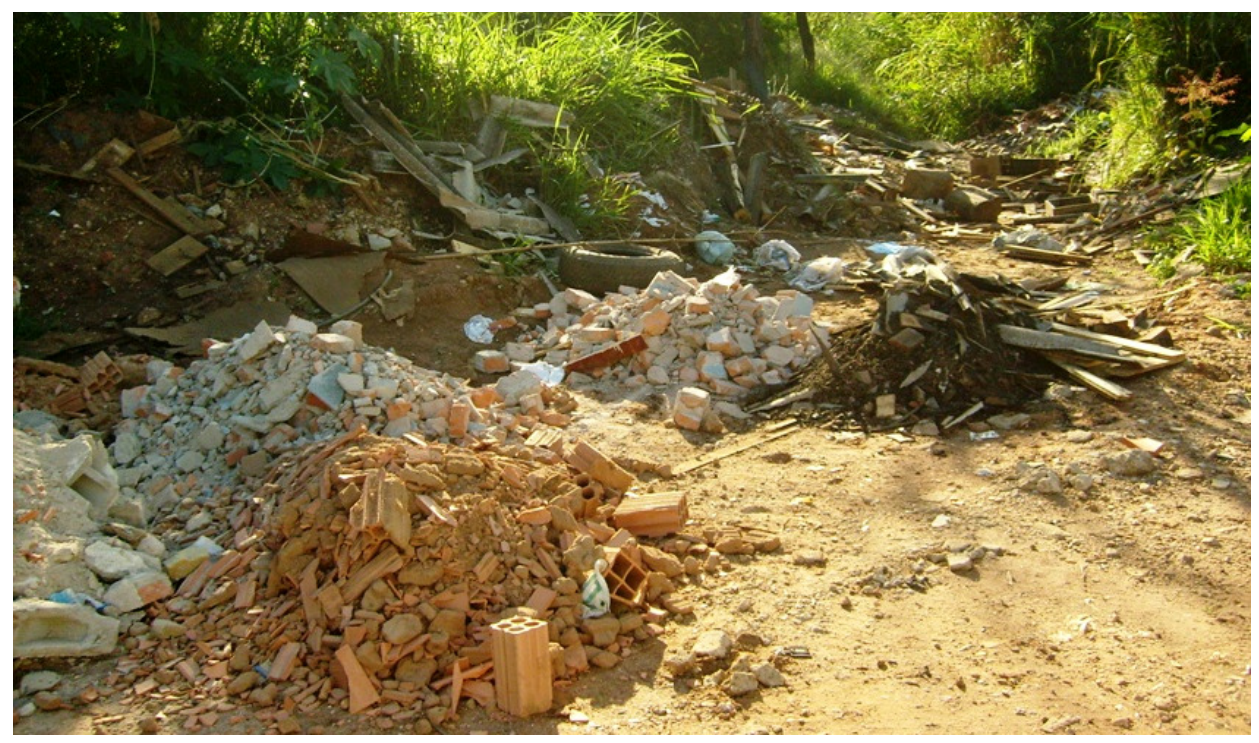

Figura 2.2 - Disposição irregular de RCD próximo à Usina de Reciclagem de Resíduos da Construção Civil de São Carlos.

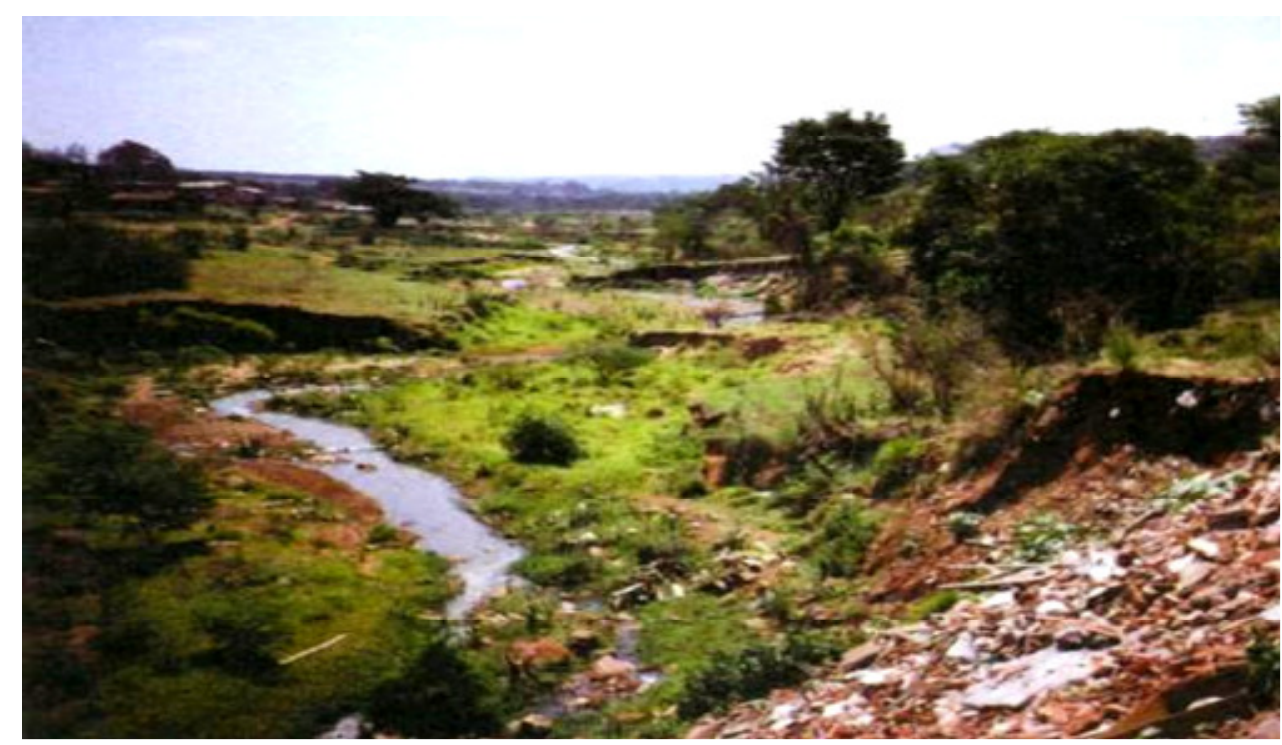

Figura 2.3 - Local de descarte clandestino na Avenida da Integração junto ao córrego da Água Quente - São Carlos-SP (MARQUES, 2005). 
Em relação à gestão dos $\mathrm{RCD}$, verifica-se que a maioria das prefeituras municipais realiza apenas medidas corretivas, isto é, de tempos em tempos, suas equipes de limpeza realizam operações de coleta de entulhos em pontos de disposição irregular. Contudo, esse tipo de solução não resolve o problema, a população sem acesso a dispositivos adequados de coleta acaba dispondo novamente seus resíduos no mesmo local.

\subsection{RECICLAGEM DOS RCD}

A reciclagem dos resíduos de construção e demolição consiste no processo de reaproveitamento desses materiais após sua transformação. Essa permite que grandes quantidades de entulhos sejam utilizadas de forma racional (EC, 2000), representando uma forma de converter um produto descartado em um material de alta qualidade. De acordo com Wilburn e Goonan (1998), a reciclagem também tem o potencial de estender a vida útil dos recursos naturais, completando o abastecimento dos recursos, reduzindo os impactos ambientais e promovendo o desenvolvimento sustentável.

Os resíduos de construção e demolição podem ser reciclados na forma de agregados por meio de um beneficiamento, constituído de operações de triagem, britagem, peneiramento e armazenamento. Geralmente, os agregados reciclados são classificados de acordo com sua constituição predominante em dois grupos, agregados reciclados de concreto e agregados reciclados mistos. 


\subsubsection{Reciclagem de RCD na Europa}

A primeira utilização significativa de agregados reciclados provenientes de entulhos aconteceu após a Segunda Guerra Mundial. Durante o período de reconstrução da Europa, era necessário, por um lado, satisfazer a enorme demanda por materiais de construção e, por outro lado, remover a grande quantidade de escombros das cidades destruídas. A reciclagem desses resíduos possibilitou na época não só uma redução nos custos de limpeza, mas também contribuiu para o abastecimento de materiais de construção (HANSEN, 1992). Desde o final dessa guerra, os europeus assumiram a liderança no desenvolvimento de técnicas de reciclagem de resíduos da construção (WILBURN; GOONAN, 1998).

De acordo com o relatório "Recycled Materials in European Highway Environments: Uses, Technologies, and Policies" (FHWA, 2000), uma gama de fatores influencia o sucesso da reciclagem dos países europeus, tais como a falta de material virgem, a oposição pública à exploração de jazidas minerais e à deposição de resíduos em aterros, e os custos elevados de transporte de matéria-prima.

Em relação à questão cultural, a opinião pública européia possui uma conscientização sobre a importância da reciclagem que vêm se consolidando ao longo das últimas décadas. Além disso, existe um grande esforço dos governos em informar e educar a população sobre os programas que promovem a reciclagem. Essa divulgação é considerada como um elemento-chave para estimular a reciclagem (FHWA, 2000). A Tabela 2.3 apresenta a porcentagem reciclada ou reutilizada de RCD em alguns países membros da União Européia. 
Tabela 2.3 - Porcentagem reutilizada ou reciclada de RCD em alguns países membros da União Européia (SYMONDS, 1999).

\begin{tabular}{cc}
\hline PAís & $\begin{array}{c}\text { TAXA DE RECICLAGEM } \\
\text { DE RCD (\%) }\end{array}$ \\
\hline Holanda & 90 \\
Bélgica & 87 \\
Dinamarca & 81 \\
Finlândia & 45 \\
Reino Unido & 45 \\
Áustria & 41 \\
Suécia & 21 \\
Alemanha & 17 \\
França & 15 \\
Itália & 9 \\
Espanha & $<5$ \\
Grécia & $<5$ \\
Portugal & $<5$ \\
Irlanda & $<5$ \\
\hline
\end{tabular}

Analisando-se a Tabela 2.3, verifica-se que as taxas de reciclagem diferem consideravelmente nos países membros da União Européia. Os países do sul da Europa (Itália, Espanha, Portugal, Grécia) possuem baixos níveis de reciclagem, enquanto Holanda, Bélgica e Dinamarca apresentam maiores taxas. Segundo o relatório da Comissão Européia "Management of Construction and Demolition Waste" (EC, 2000), os métodos empregados pelos países para a gestão dos resíduos da construção e demolição variam consideravelmente, bem como os níveis de proteção ambiental, os quais se refletem diretamente na taxa de reciclagem.

$\mathrm{Na}$ Holanda, a alta taxa de reciclagem, maior da União Européia, está relacionada com avanços em alguns aspectos do modelo de sustentabilidade. $O$ governo desse país tem uma política que minimiza o uso de materiais naturais e promove a utilização de materiais reciclados dentro de um sistema de mercado (FHWA, 2000). 
A Dinamarca é outro exemplo de sucesso na reciclagem de resíduos de construção e demolição. Segundo EC (2000), os municípios desse país são os responsáveis pelo recolhimento do $R C D$, sendo que mais da metade deles já possuem regulamentação específica para classificação deste tipo de material. De acordo com FHWA (2000), os dinamarqueses utilizam incentivos financeiros, como impostos, taxas e subsídios, para gestão de resíduos. Esses recursos são utilizados de forma a promover o uso de tecnologias mais limpas e a reciclagem dos resíduos.

Já na Itália, Espanha, Portugal e Grécia, os recursos naturais estão disponíveis em qualidade e quantidade suficiente para atender à demanda de materiais de construção a um custo moderado. Assim, os agregados reciclados não conseguem concorrer com baixos custos dos agregados naturais, e conseqüentemente seu mercado não se desenvolve (EC, 2000).

\subsubsection{Reciclagem de RCD no Brasil}

Em 2002, diante da necessidade de se reduzir os impactos dos resíduos da construção civil, foi publicada Resolução CONAMA n 307 (CONAMA, 2002) que determina diretrizes, critérios e procedimentos para a gestão deste tipo de resíduo. Segundo esta resolucão, os geradores são responsáveis por seus resíduos e devem ter como objetivo prioritário a não geração e, secundariamente, a redução, a reutilização, a reciclagem e a destinação final.

Outro avanço no tocante à reciclagem de resíduos de construção e demolição no país é decorrente da publicação pela Associação Brasileira de Normas Técnicas 
(ABNT), em 2004, de normas específicas relativas à sua gestão e seu emprego, as quais são citadas a seguir:

- NBR 15112 - Resíduos da construção civil e resíduos volumosos Áreas de transbordo e triagem - Diretrizes para projeto, implantação e operação;

- NBR 15113 - Resíduos sólidos da construção civil e resíduos inertes Aterros - Diretrizes para projeto, implantação e operação;

- NBR 15114 - Resíduos sólidos da construção civil - Áreas de reciclagem - Diretrizes para projeto, implantação e operação;

- NBR 15115 - Agregados reciclados de resíduos sólidos da construção civil - Execução de camadas de pavimentação - Procedimentos;

- NBR 15116 - Agregados reciclados de resíduos sólidos da construção civil - Utilização em pavimentação e preparo de concreto sem função estrutural - Requisitos.

Mesmo com a publicação de legislações e normas técnicas específicas do assunto, o Brasil ainda se mostra aquém do ideal no que se diz respeito à reciclagem de resíduos de construção e demolição. Em um país com mais de 5560 municípios (IBGE, 2001), havia em 2004 apenas 14 usinas de reciclagem de RCD, espalhadas em 12 cidades (NUNES, 2004). Em 2007, de acordo com Moreira et al. (2007), esse número aumentou para 16 unidades.

A primeira central de reciclagem de resíduos de construção e demolição do Brasil foi instalada na cidade de São Paulo em novembro de 1991. Essa localizavase em uma área de $20.000 \mathrm{~m}^{2}$ em Itatinga, zona sul do município, e tinha uma 
capacidade inicial de 100 t/h. Após dez anos, em 2001, essa usina foi transferida para a área de aterro de inertes de Itaquera (NUNES, 2004).

Mesmo não tendo sido a primeira cidade brasileira a aderir à reciclagem, Belo Horizonte é uma referência fundamental na gestão dos resíduos de construção e demolição. Atualmente, a prefeitura municipal deste município disponibiliza à população três estações de reciclagem de entulho. A primeira, a do Estoril, começou a funcionar em novembro de 1995, a segunda, a da Pampulha, foi implantada em 1996 e a terceira, a da Central de Tratamento de Resíduos Sólidos - CTRS, iniciou suas operações em 2006. De acordo com Catapreta et al. (2008), essas unidades juntas têm capacidade nominal para reciclar aproximadamente 1.000 toneladas de resíduos por dia. As fotos dessas usinas são apresentadas na Figura 2.4.

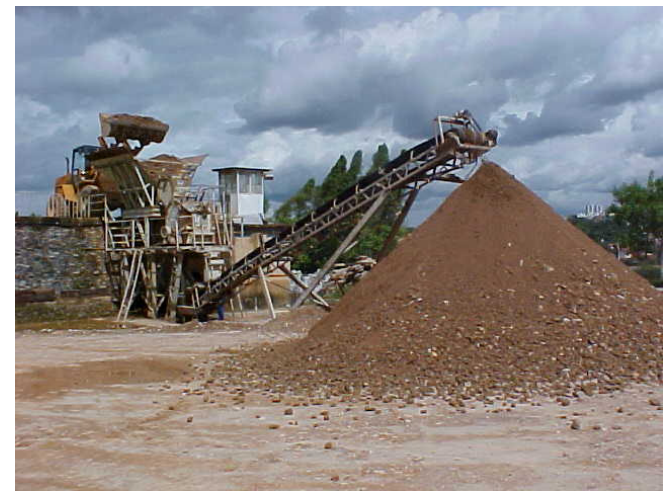

(a) Unidade de reciclagem da Pampulha

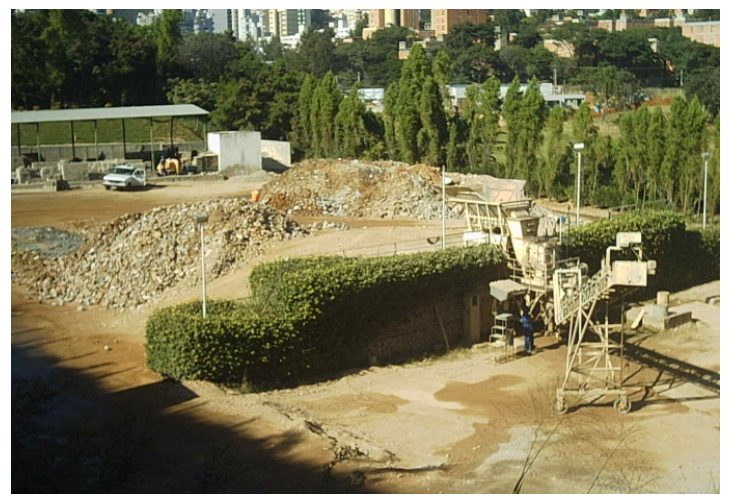

(b) Unidade de reciclagem do Estoril

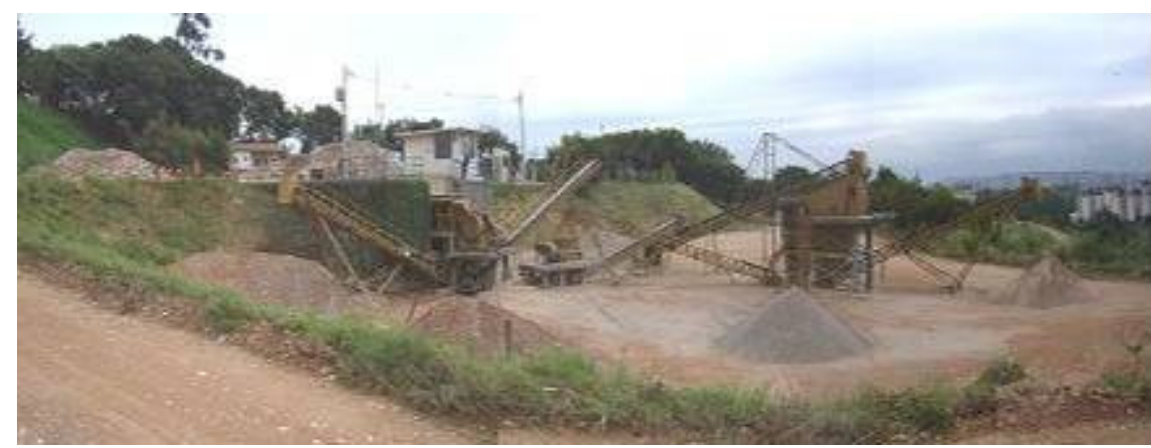

(c) Unidade de reciclagem da CTRS

Figura 2.4 - Unidades de reciclagem de entulho de Belo Horizonte (CATAPRETA et al., 2008). 


\subsubsection{Aplicações de Agregados Reciclados de RCD}

Os agregados reciclados de resíduos de construção e demolição podem ser empregados em diversas aplicações, tais como em serviços de drenagem, na construção de aterros e de camadas de pavimentos, na confecção de argamassa e concreto, na fabricação de pré-moldados (blocos, meio-fio e outros), entre outros. A Figura 2.4 ilustra algumas dessas aplicações no Município de Belo Horizonte - MG.

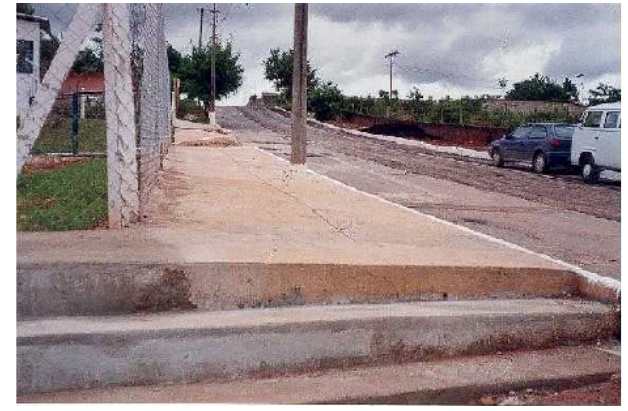

(a) Calçada (PINTO, 1999)

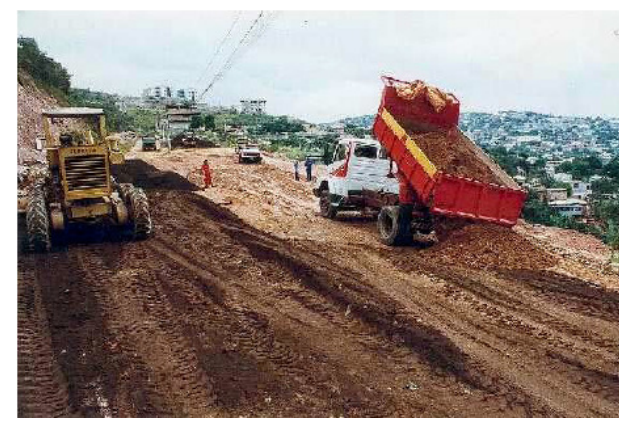

(c) Execução de aterro (PINTO, 1999)

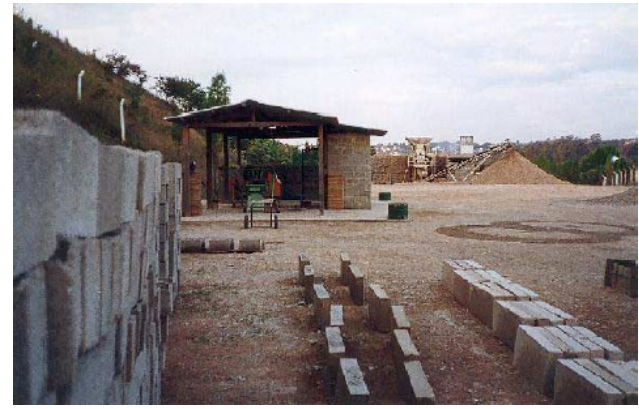

(b) Produção de pré-moldados (PINTO, 1999)

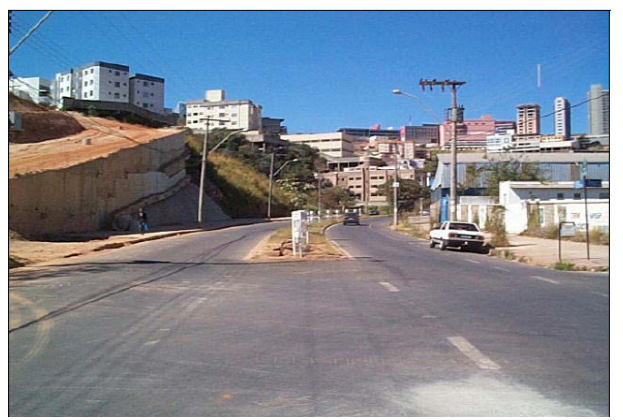

(d) Via pública pavimentada - Av. Mário Werneck (FERNANDES, 2004)

Figura 2.5 - Emprego de agregados reciclados de RCD em Belo Horizonte.

\subsection{EMPREGO DE AGREGADOS RECICLADOS DE RCD EM PAVIMENTAÇÃO}

A utilização de agregados reciclados provenientes de resíduos de construção e demolição em camadas de base e sub-base apresenta diversas vantagens às 
administrações municipais. Segundo Motta (2005), o maior atrativo para emprego de agregados reciclados em camadas de pavimento é o fator econômico, uma vez que esses materiais têm sido vendidos, geralmente, a preços inferiores aos dos convencionalmente utilizados em pavimentação. De acordo com Carneiro et al. (2001), a utilização de RCD dessa forma é a maneira mais simples de aproveitamento por exigir processos de reciclagem menos sofisticados.

\subsubsection{Experiência de São Paulo - SP}

No Município de São Paulo, mesmo antes da instalação da usina de reciclagem, os resíduos de construção e demolição já eram utilizados para o revestimento primário de subleito de vias urbanas, visando minimizar a ocorrência de lama nos períodos chuvosos ou poeira nos períodos de estiagem. É importante destacar que apesar dessas ruas não terem recebido uma pavimentação definitiva, esses locais passaram a requerer menores atividades de manutenção. Entretanto, a primeira obra com acompanhamento técnico ocorreu em 1984, na Rua Gervásio da Costa, região oeste da cidade São Paulo. Nesta via, o RCD foi empregado no reforço do subleito. Esse pavimento, executado pela Prefeitura Municipal de São Paulo (PMSP) e monitorado pelo Instituto de Pesquisas Tecnológicas (IPT), apresentou um excelente desempenho (BODI et al., 1995).

A Prefeitura Municipal de São Paulo incentiva a utilização de agregados reciclados de RCD na construção de camadas de pavimentos de diversas formas. Em 2003, a PMSP publicou a especificação de serviço PMSP/SP ETS - 001/2003 que define os critérios para a execução de camadas de reforço de subleito, sub-base 
ou base de pavimentos com agregados reciclados da construção civil. No final de 2006, por meio de um decreto, as contratações de obras e serviços de pavimentação de vias públicas passaram a contemplar de modo preferencial o emprego de agregados reciclados. A partir de julho de 2007 , os projetos prevendo materiais reciclados começaram a ser obrigatórios, nos casos onde há viabilidade técnica (PMSP, 2008).

No tocante ao aspecto econômico, verifica-se que os custos unitários de construção de camadas de bases e sub-bases neste município utilizando agregados reciclados de RCD são menores do que os empregando brita graduada. Esses custos podem ser comparados na Tabela 2.4 .

Tabela 2.4 - Custo unitário de execução de bases e sub-bases de pavimentos. Fonte: Tabela de custos unitários PMSP - Julho de 2008 (PMSP, 2008).

\begin{tabular}{cc}
\hline DESCRIÇÃO & CUSTO UNITÁRIO $\left(\mathbf{R} \$ \mathbf{m}^{\mathbf{3}}\right)$ \\
\hline Base de brita graduada & 66,34 \\
Base de agregado reciclado & 55,42 \\
Sub-base de solo melhorado & 36,80 \\
$\quad$ com brita (60\% em volume) & 31,56 \\
Sub-base de solo melhorado com & agregado reciclado (60\% em volume)
\end{tabular}

Analisando-se a Tabela 2.4, é possível observar que o custo unitário de execução de uma base de agregado reciclado é $16 \%$ menor do que o de uma base com brita graduada. Já para camadas de sub-bases melhoradas com agregado, a utilização de agregados reciclados apresenta um custo unitário 14\% inferior ao praticado quando se emprega brita. 


\subsubsection{Experiência de Belo Horizonte - MG}

A Prefeitura Municipal de Belo Horizonte (PMBH) emprega resíduos de construção e demolição na construção de camadas de bases e sub-bases de pavimentos desde 1996. Segundo Dias (2004), de 1996 até 2001, foram utilizadas quase 137.000 toneladas de RCD na implantação ou reconstrução de 271 vias, totalizando cerca $400 \mathrm{~km}$ de ruas.

Um aspecto interessante sobre o emprego de agregados reciclados de RCD em pavimentação foi observado pelos engenheiros deste município. De acordo com Pinto (1999), após a reabertura de uma base, meses depois de sua execução, os técnicos se surpreenderam com a "coesão" apresentada por essa camada. A reabertura permitiu observar que, diferentemente das bases com agregados naturais, nas quais ocorre travamento mecânico entre partículas e uma desagregação quando o material é desconfinado, as bases com RCD reciclado apresentaram-se consolidadas, demonstrando a ocorrência de componentes reativos no RCD que agiram com a exposição à umidade na execução e umidade natural dos solos locais (PINTO, 1999). A Figura 2.6 mostra o corte feito nessa base. 


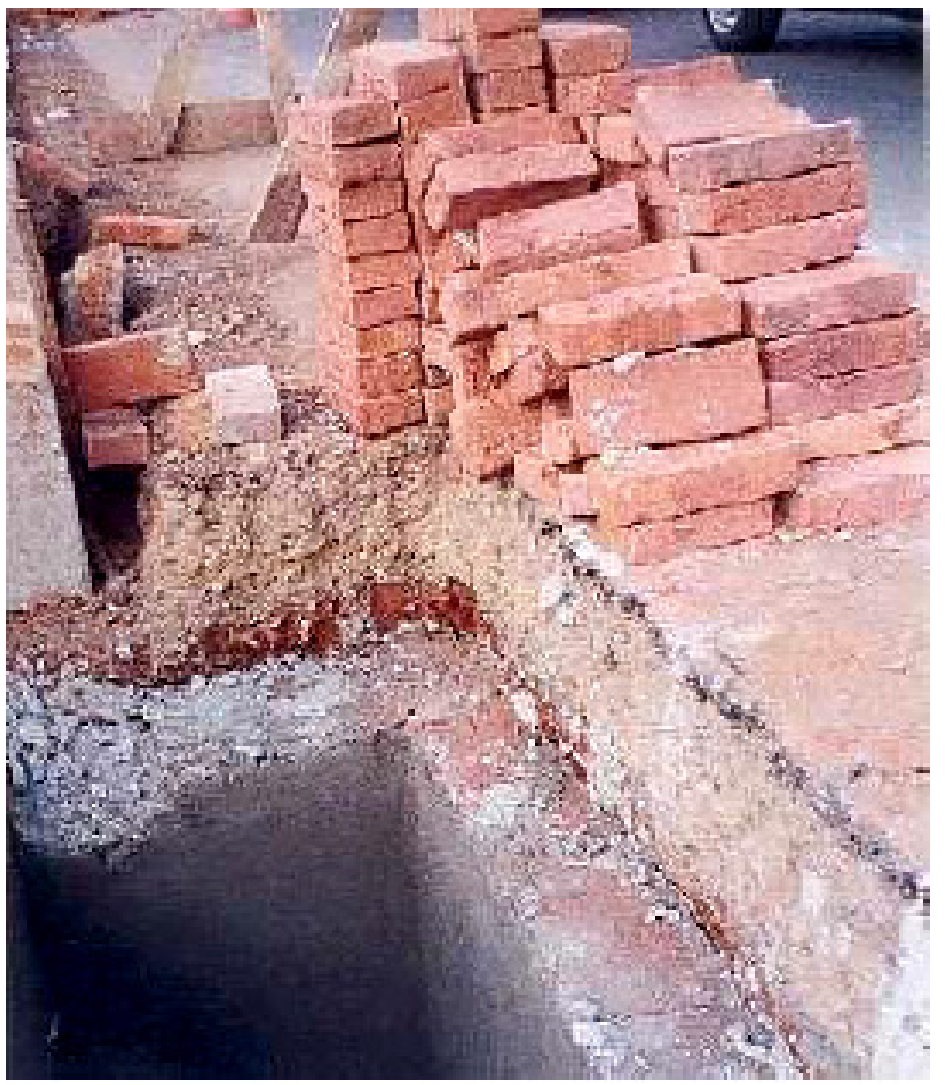

Figura 2.6 - Corte de um pavimento executado com base de agregados reciclados de RCD em Belo Horizonte (PINTO, 1999).

\subsubsection{Pista experimental de Goiânia - GO}

No final de 2003, foi construída, na Rua dos Ciprestes em Goiânia, uma pista experimental empregando uma mistura de agregados reciclados de resíduos de construção e demolição com um solo argiloso em suas camadas de base e subbase. A construção foi realizada através de uma parceria entre a Prefeitura Municipal de Goiânia, Universidade de Brasília, Universidade Federal de Goiás e empresas da região, como parte integrante do programa municipal de gerenciamento de resíduos sólidos da construção civil (OLIVEIRA, 2007). 
Os resíduos empregados na construção desta pista foram processados em agregados reciclados de três frações granulométricas, denominadas de brita de 19 $\mathrm{mm}$, brita de $9,5 \mathrm{~mm}$ e areia. A mistura foi proporcionada combinando essas frações com um solo argiloso retirado do próprio local. A distribuição granulométrica da mistura foi enquadrada na faixa $D$ da especificação do DNER de bases estabilizadas granulometricamente (MENDES et al., 2004). O solo utilizado foi classificado segundo a classificação MCT, como sendo do grupo LG' - solo argiloso de comportamento laterítico.

De acordo com Mendes et al. (2004), a pista experimental tem um comprimento de 100 metros, sendo que a parte construída com RCD tem cerca de 50 metros. As características das camadas do pavimento são apresentadas na Tabela 2.5 e alguns aspectos construtivos desta pista são apresentados na Figura 2.7.

Tabela 2.5 - Características da pista experimental de Goiânia (Adaptado de Mendes et al., 2004).

\begin{tabular}{cccc}
\hline CAMADA & $\begin{array}{c}\text { ENERGIA DE } \\
\text { COMPACTAÇÃO }\end{array}$ & $\begin{array}{c}\text { ESPESSURA } \\
\text { (cm) }\end{array}$ & COMPOSIÇÃO \\
\hline Revestimento & - & 5 & CBUQ \\
Base & Intermediária & 15 & $\begin{array}{c}25 \% \text { de brita } 19 \mathrm{~mm}, 25 \% \text { de brita } 9,5 \\
\mathrm{~mm}, 25 \% \text { de areia e } 25 \% \text { de argila }\end{array}$ \\
Sub-base & Intermediária & 15 & $\begin{array}{c}33 \% \text { de brita } 19 \mathrm{~mm}, 33 \% \text { de brita } 9,5 \\
\mathrm{~mm}, 17 \% \text { de areia e } 17 \% \text { de argila }\end{array}$ \\
\hline
\end{tabular}

Em novembro de 2004, a pista experimental foi liberada para o tráfego e o monitoramento de campo foi iniciado. Para o acompanhamento do desempenho do pavimento, foram realizadas medidas de deflexão com a viga Benkelman e de penetração com o penetrômetro dinâmico de cone. Além disso, foram feitos ensaios pressiométricos e de prova de carga (OLIVEIRA, 2007). 


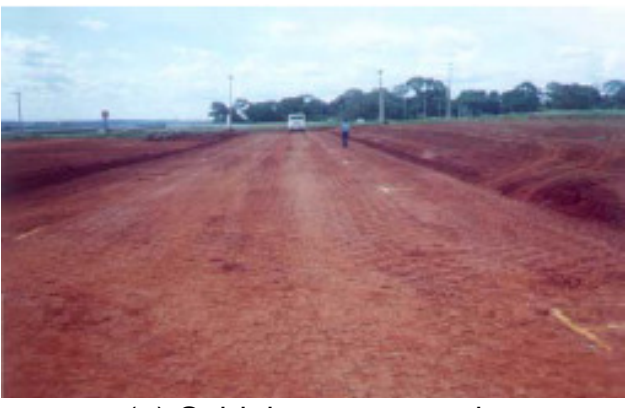

(a) Subleito compactado

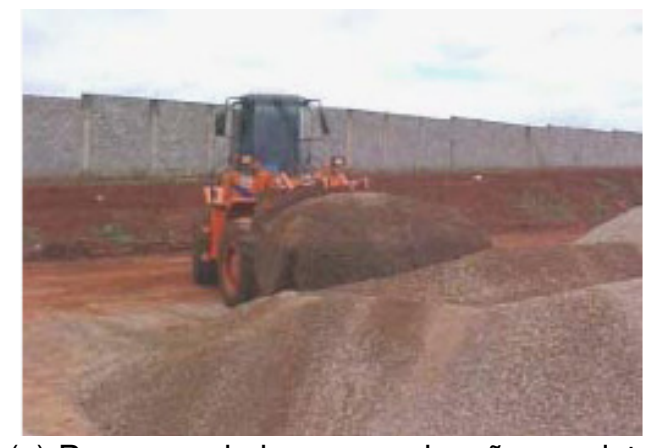

(c) Processo de homogeneização na pista

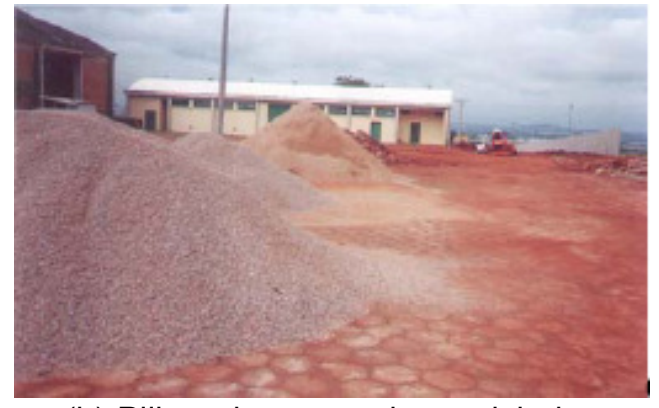

(b) Pilhas de agregados reciclados

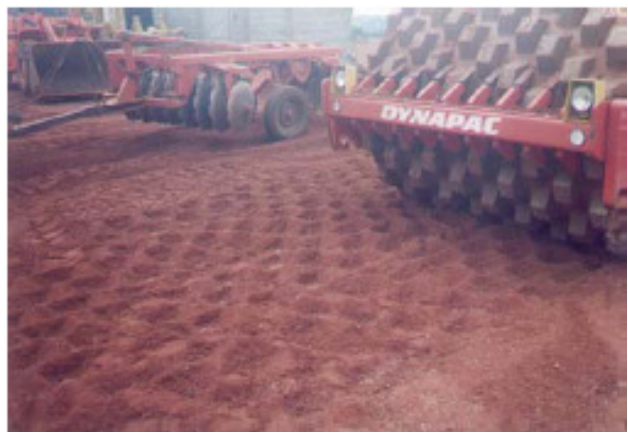

(d) Compactação da sub-base

Figura 2.7 - Detalhes construtivos da execução da pista experimental de Goiânia (OLIVEIRA, 2007).

A título de exemplificação, a Tabela 2.6 apresenta os valores das deflexões características determinadas para as cinco etapas de ensaios de medidas de deflexões com a viga Benkelman realizadas sobre o revestimento asfáltico da pista experimental, entre os meses de janeiro de 2004 a maio de 2006. De acordo com Oliveira (2007), os cálculos das deflexões características $\left(D_{c}\right)$ e das deflexões máximas admissíveis $\left(D_{a d m}\right)$ foram realizados conforme as recomendações das normas DNER PRO 011/79 e DNER PRO 269/94. Para o cálculo das deflexões admissíveis foi utilizado um número $\mathrm{N}$ igual a $10^{6}$ repetições do eixo padrão.

Tabela 2.6 - Resumo das deflexões características e admissíveis da pista experimental de Goiânia (OLIVEIRA, 2007).

\begin{tabular}{|c|c|c|c|}
\hline DATA & $D_{c}\left(10^{-2} \mathrm{~mm}\right)$ & $\mathrm{D}_{\mathrm{adm}}$ PRO $011\left(10^{-2} \mathrm{~mm}\right)$ & $\mathrm{D}_{\mathrm{adm}}$ PRO $269\left(10^{-2} \mathrm{~mm}\right)$ \\
\hline Jan/ 2004 & 57 & 90 & 105 \\
\hline Set/ 2004 & 52 & 90 & 105 \\
\hline Mai/ 2005 & 78 & 90 & 105 \\
\hline Nov/2005 & 78 & 90 & 105 \\
\hline Mai/ 2006 & 71 & 90 & 105 \\
\hline
\end{tabular}


Analisando-se a Tabela 2.6, é possível observar que as deflexões características da pista experimental no decorrer do tempo foram menores que as deflexões máximas admissíveis, contudo foram crescentes.

Oliveira (2007) ainda relata que depois de decorridos dois anos e nove meses da ação do tráfego, a pista experimental não apresentou defeitos superficiais aparentes, nem deformações que comprometam sua estrutura e funcionalidade.

Dessa forma, este pesquisador concluiu que os resultados apresentados para o trecho experimental indicam que os agregados reciclados de resíduos sólidos da construção civil com características semelhantes às estudadas são apropriados para o emprego em camadas de base e sub-base de estruturas de pavimentos.

\subsection{AGREGADOS RECICLADOS DE CONCRETO}

Neste item, são apresentadas informações mais detalhadas sobre o emprego de agregados reciclados de concreto (ARC) na construção de camadas de base e sub-base de pavimentos, tema deste trabalho, bem como suas propriedades físicas e seu comportamento mecânico.

Nos Estados Unidos, a utilização de agregados reciclados de concreto para construção de camadas de base de pavimentos é bem intensa. Estima-se que $85 \%$ de todos os resíduos de concreto reciclados são empregados como bases de pavimentos rodoviários, com pequenas quantidades usadas em concretos asfálticos (WILBURN; GOONAN, 1998). De acordo com o relatório do FHWA “Transportation Applications of Recycled Concrete Aggregate" (FHWA, 2004), dos 50 Estados 
americanos, 38 já utilizam ARC para construção de camadas de base e sub-base de pavimentos, conforme ilustrado na Figura 2.8.

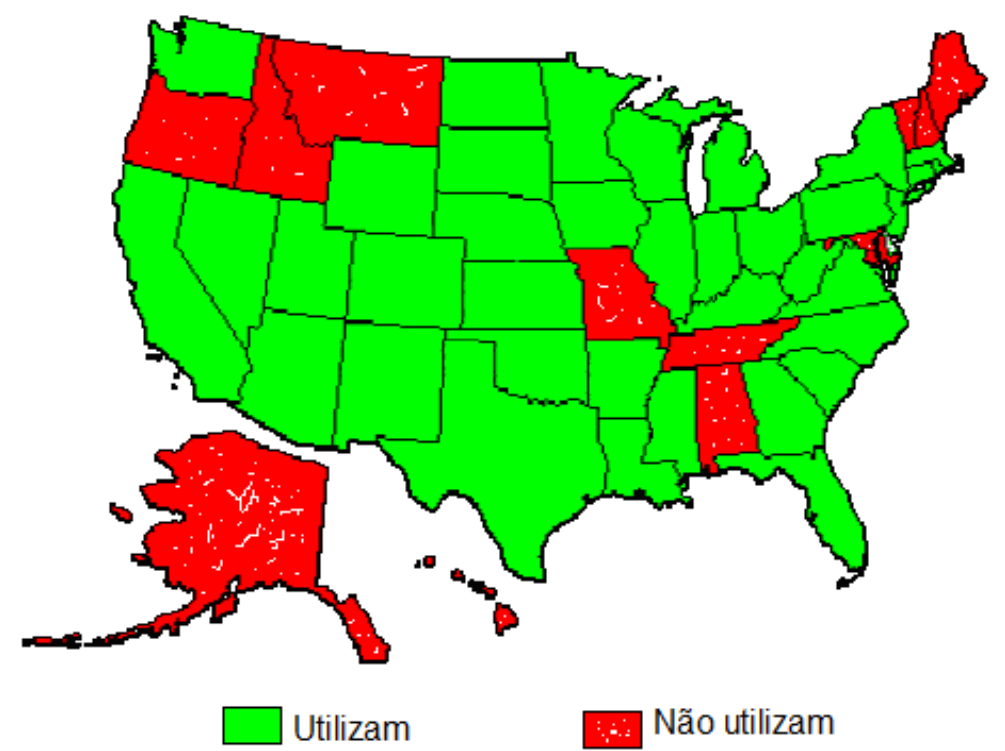

Figura 2.8 - Utilização de ARC em camadas de base e sub-base de pavimentos nos EUA (FHWA, 2004).

Um dos motivos para o aumento da utilização de ARC nos Estados Unidos em camadas de base é que a disponibilidade de agregados virgens, em diversos locais, está começando a ficar limitada. Nestas áreas, o uso de agregados reciclados, além de ser ambientalmente correto, é considerado como economicamente atrativo (FHWA, 2004).

No Brasil, os resíduos de concreto correspondem a uma parcela significativa dos resíduos de construção e demolição, conforme visto no item 2.2.2. Sua reciclagem na forma de agregados é uma alternativa interessante para aumentar a oferta de materiais de construção. Esses podem ser empregados na construção de camadas de base e sub-base de pavimentos como substitutos aos agregados 
convencionais, com conseqüente redução na exploração de recursos naturais não renováveis.

\subsubsection{Propriedades Físicas}

Para o emprego de um material em camadas de pavimentos, diversos ensaios de caracterização são importantes. Assim, neste tópico, será apresentada uma visão geral das principiais características físicas dos agregados reciclados de concreto, como absorção, densidade, e abrasão Los Angeles.

O agregado reciclado de concreto apresenta maior absorção do que os agregados naturais devido à presença de argamassa aderida a seus grãos (POON et al, 2006). Segundo Carneiro et al. (2001), "a absorção de água é uma das diferenças mais marcantes entre agregado natural e agregado reciclado". A faixa de valores típicos de absorção dos ARC, de acordo com Saeed et al(2007), varia de $2 \%$ a $6 \%$ para agregados reciclados graúdos e de $4 \%$ a $8 \%$ para agregados miúdos.

A massa específica dos agregados reciclados de concreto é, em geral, inferior a dos agregados naturais (POON et al, 2006; SAEED et al 2007). Segundo Hansen (1992), a massa específica do ARC é de 5 a $10 \%$ mais baixa do que os agregados que os originaram devido à significativa presença de argamassa.

Geralmente, a abrasão Los Angeles dos agregados reciclados do concreto é maior do que a dos agregados naturais, porém bem inferior aos valores observados em agregados reciclados mistos. De acordo com FHWA (1997), os valores típicos 
deste parâmetro variam entre 20 e $45 \%$. A Tabela 2.7 mostra alguns valores de abrasão Los Angeles de ARC encontrados na bibliografia consultada.

Tabela 2.7 - Abrasão Los Angeles de agregados reciclados de concreto.

\begin{tabular}{ccc}
\hline PROCEDÊNCIA & FONTE & ABRASÃO LOS ANGELES (\%) \\
\hline Austrália & Nataatmadja et al. (2001) & 21 a 30 \\
Taiwan & Huang et al. (2002) & 29 \\
EUA & Kuo et al. (2002) & 42 a 48 \\
EUA & Blankenagel et al. (2006) & 31 \\
Brasil & Fernandes (2004) & 52 \\
Brasil & Oliveira (2007) & 33 a 38 \\
\hline
\end{tabular}

\subsection{2. Índice de Suporte Califórnia (CBR)}

Petrarca e Galdiero (1984) realizaram uma avaliação contínua ao longo de seis anos sobre a utilização do ARC produzido de uma única usina de reciclagem em bases de pavimentos no Estado de Nova York (EUA). Segundo estes pesquisadores, após uma quantidade expressiva de testes, o ARC se mostrou consistente ao longo do tempo e cumpriu todos os requisitos necessários para um excelente desempenho, bem acima das especificações mínimas para emprego de materiais para bases granulares densas. Esse material exibiu uma alta capacidade de suporte, a média dos 157 testes de CBR foi de 148\%. A Figura 2.9 apresenta a variação do CBR do ARC de Nova York ao longo dos seis anos de análise.

Segundo FHWA (1997), o Índice de Suporte Califórnia típico dos agregados reciclados de concreto varia de $94 \%$ a 148\%. Já de acordo com Saeed et al (2007), este parâmetro varia de $94 \%$ a $184 \%$. 


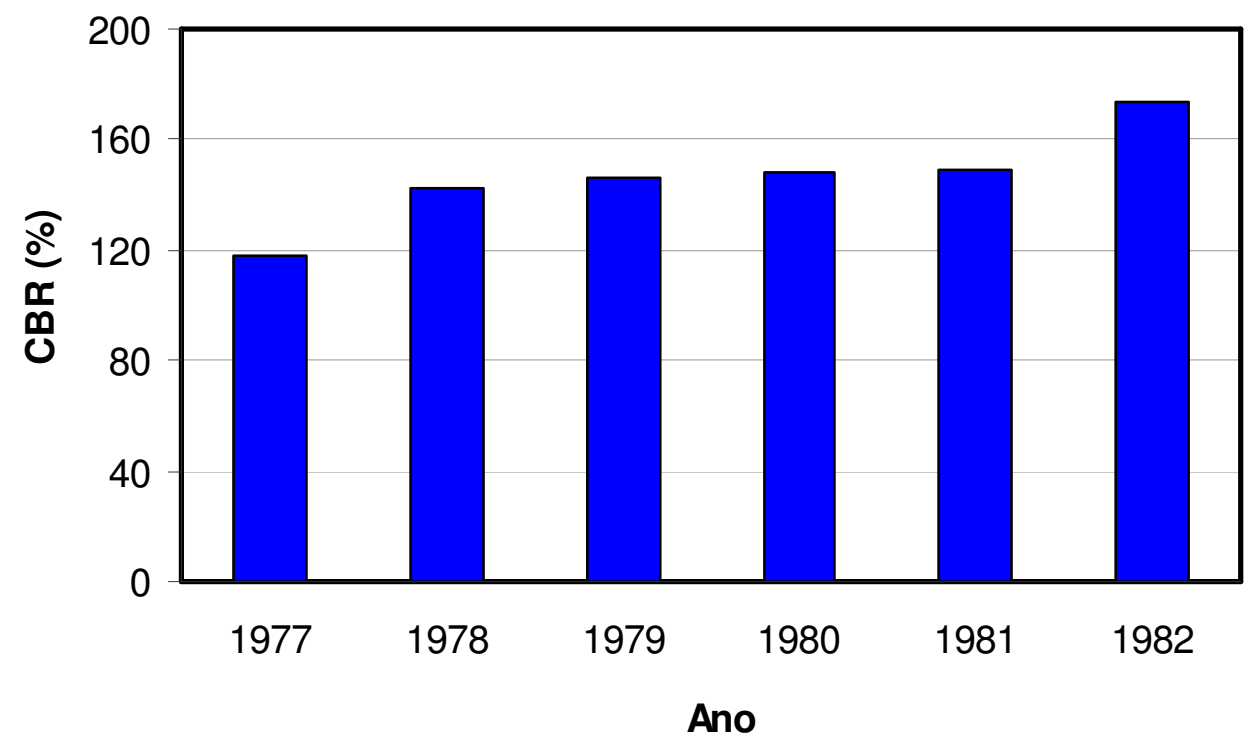

Figura 2.9 - Avaliação do CBR do ARC de Nova York (PETRARCA; GALDIERO, 1984).

\subsubsection{Comportamento resiliente}

\subsubsection{Considerações básicas}

O primeiro a estudar o comportamento resiliente dos materiais empregados em pavimentação foi Francis Hveem, na década de 1930. Este entendeu que o trincamento por fadiga nos revestimentos asfálticos, principal defeito dos pavimentos, estava relacionado com as deformações recuperáveis (resilientes) das camadas subjacentes do pavimento.

A determinação do módulo de resiliência é considerada como uma das formas mais adequadas de avaliar o comportamento mecânico de um material empregado em pavimentação. 
O módulo de resiliência (MR) é definido como a relação entre a tensão desvio $\left(\sigma_{d}=\sigma_{1}-\sigma_{3}\right)$, aplicada no ensaio triaxial cíclico, pela deformação resiliente axial vertical $\left(\varepsilon_{r}\right)$, conforme visto na Equação 2.1.

$$
M_{R}=\frac{\sigma_{d}}{\varepsilon_{r}}
$$

No caso de solos e britas, o módulo de resiliência é obtido através do ensaio triaxial cíclico. De acordo com Medina e Motta (2005), o ensaio triaxial cíclico foi introduzido nas pesquisas de pavimentação somente a partir da década de 1950 pelo Prof. H. Bolton Seed da Universidade de Califórnia, Berkeley. Neste ensaio, o corpo-de-prova é submetido a cargas repetidas, de baixa intensidade, por um intervalo de tempo curto, que procuram simular em laboratório as condições de carregamentos impostas pelo tráfego na estrutura do pavimento. Um ciclo de carregamento é o somatório do tempo de aplicação da carga, $0,1 \mathrm{~s}$, e do tempo de repouso entre aplicações sucessivas, 0,9s.

Além disso, o módulo de resiliência é empregado em métodos mecanísticos de dimensionamento de pavimentos que permitem a previsão do comportamento dos pavimentos através do cálculo de tensões, deformações e deslocamentos. Nos Estados Unidos, o método de dimensionamento de pavimentos estabelecido pela AASHTO em 1986, revisado em 1993, substituiu o Índice de Suporte Califórnia (CBR) pelo módulo de resiliência do subleito na expressão de dimensionamento das estruturas.

Uma vez que a maioria dos materiais empregados em pavimentação não são materiais elásticos lineares, os módulos de resiliência dependem do estado de 
tensão atuante. Assim, vários modelos matemáticos que representem sua variação em função do estado de tensão têm sido propostos. Além do estado de tensões, outros fatores influenciam no módulo de resiliência, como a natureza do material e seu estado físico, como por exemplo sua umidade e densidade.

\subsubsection{Módulo de resiliência de ARC}

O comportamento resiliente dos agregados reciclados de concreto é influenciado por diversos fatores, tais como graduação, composição, grau de compactação e resistência à compressão do concreto de origem.

A influência da graduação, da composição e do grau de compactação sobre o comportamento mecânico de agregados reciclados foi relatada por Molenaar e Van Niekerk (2002). Segundo esses pesquisadores, a análise dos valores de módulo de resiliência indicou que a graduação foi o fator que menos influenciou na rigidez dos agregados reciclados, enquanto que o grau de compactação foi o fator mais importante. A composição dos agregados reciclados também influenciou expressivamente nos resultados, observou-se que os agregados que eram constituídos com maiores porcentagens de concreto apresentaram módulos de resiliência mais altos.

Fernandes (2004) também constatou que a composição do agregado reciclado foi o fator que mais exerceu influência sobre os valores do módulo de resiliência. Os agregados reciclados de concreto apresentaram módulos de resiliência maiores do que os mistos. Ainda de acordo com esse autor, a 
granulometria, a energia de compactação e a origem geográfica do agregado exerceram pouca influência sobre este parâmetro.

Nataatmadja e Tan (2001) investigaram o comportamento resiliente de agregados reciclados de concreto empregados na construção de camadas de base e sub-base de pavimentos. Nessa pesquisa, foram analisadas quatro amostras de agregados reciclados provenientes de concretos com resistência à compressão simples de 15; 18, 49 e $75 \mathrm{MPa}$. Com base nos resultados obtidos, esses pesquisadores concluíram que quanto maior a resistência do concreto de origem do resíduo maior são os valores de módulo de resiliência dos agregados reciclados. Além disso, os autores afirmaram que o ARC apresentou um comportamento resiliente semelhante ao dos agregados convencionais utilizados em pavimentação.

A Figura 2.10 apresenta os módulos de resiliências de um agregado reciclado de concreto e de uma brita graduada, ambos oriundos do Estado de Nova Jersey, nos Estados Unidos, pesquisados por Bennert et. al. (2000). 


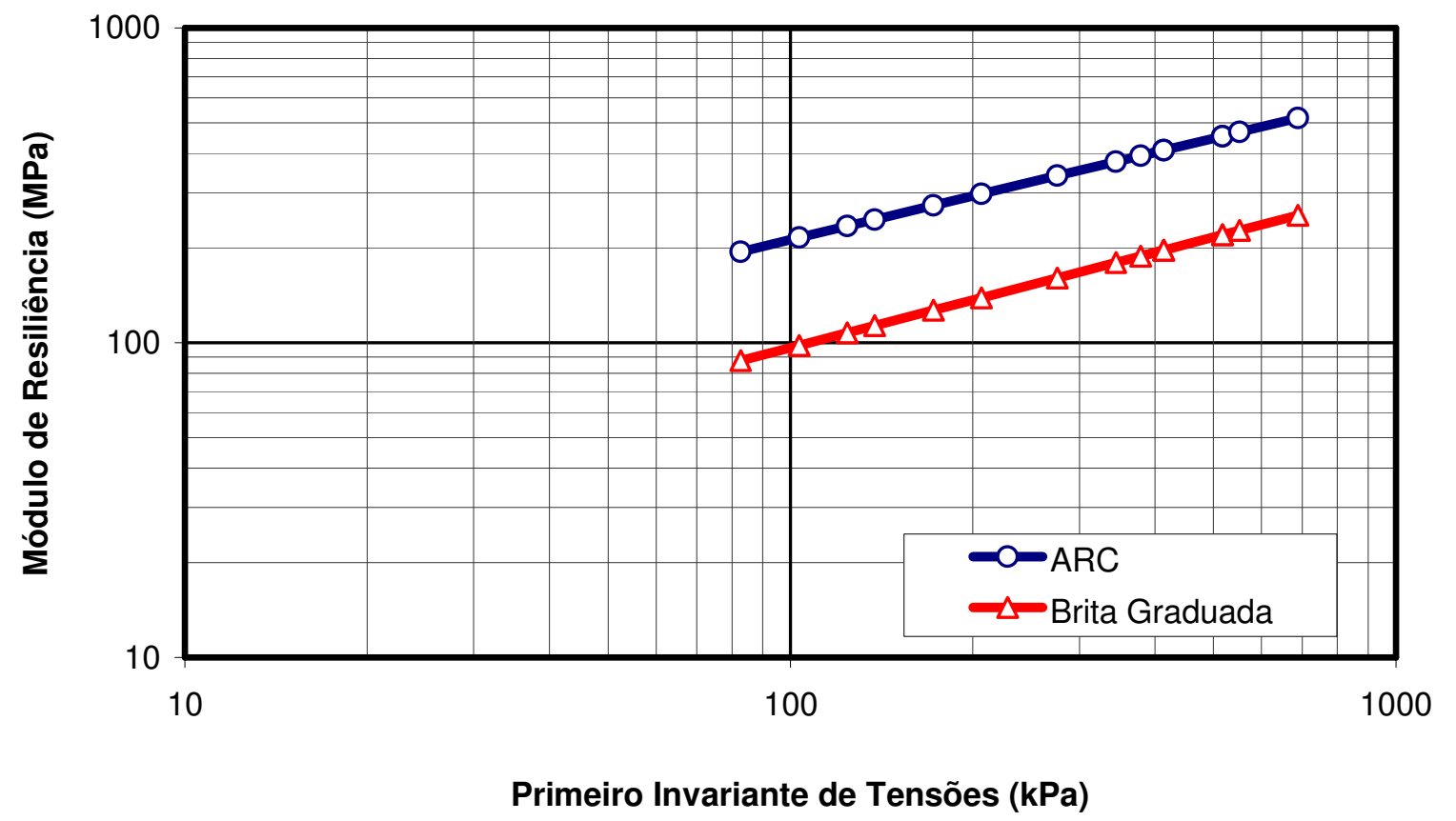

Figura 2.10 - Módulo de resiliência de agregados de Nova Jersey (BENNERT et. al., 2000).

Analisando-se a Figura 2.10, observa-se que os valores de módulo de resiliência do agregado reciclado de concreto foram superiores aos da brita graduada para todos os níveis de tensão testados.

\subsubsection{Efeito da cimentação própria}

Algumas pesquisas, como as desenvolvidas por Arm (2001), Blanknagel (2005) e Poon et al (2006), mencionam o efeito da cimentação própria do agregado reciclado de concreto quando empregado em camadas de base e sub-base. Este fenômeno proporciona um ganho de resistência e rigidez do material reciclado com o tempo. 
Blankenagel (2005) avaliou diariamente a resistência à compressão simples de um agregado reciclado de concreto, proveniente de obras de demolição do Estado de Utah (EUA), por um período de sete dias, sendo que para cada tempo de cura foram testados três corpos-de-prova. Os resultados deste estudo podem ser vistos na Figura 2.11. Analisando-se essa figura, verifica-se que os resultados apresentaram uma grande dispersão, contudo é possível observar um aumento de resistência à compressão simples do agregado reciclado de concreto no decorrer do tempo. A RCS imediata média foi em torno de $750 \mathrm{kPa}$, enquanto a com sete dias de cura foi cerca de $1250 \mathrm{kPa}$.

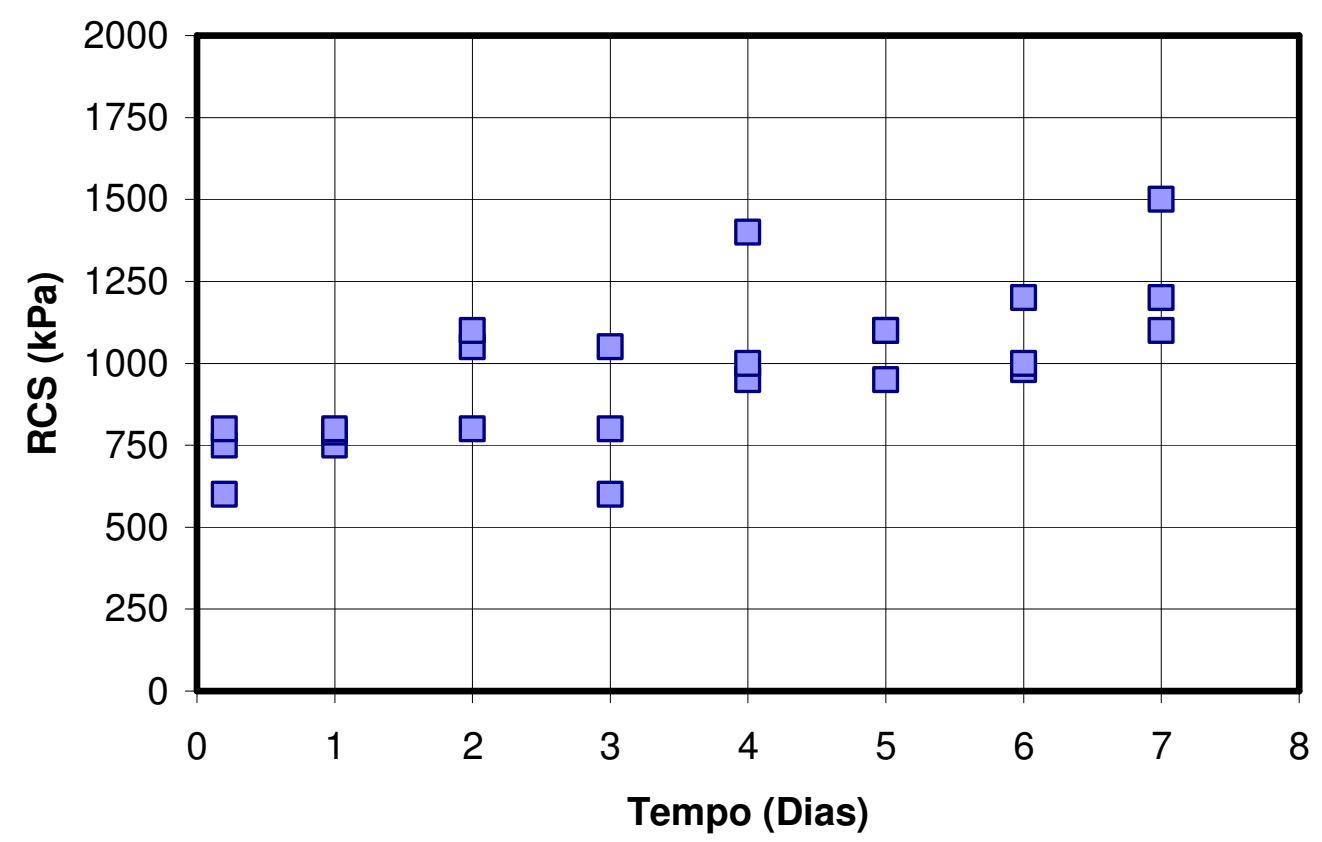

Figura 2.11 - Resultados de RCS do ARC (BLANKENAGEL, 2005).

No tocante ao trabalho de Blankenagel (2005), uma crítica pode ser feita, acredita-se que o intervalo de um dia seja um período muito curto para se avaliar a variação da resistência à compressão simples do ARC. 
A avaliação da melhoria do comportamento mecânico dos agregados reciclados de concreto ao longo do tempo também pode ser feita a partir da determinação da variação do módulo de resiliência, conforme o relatado por Arm (2001). Essa pesquisadora analisou um agregado reciclado de concreto e um agregado natural, empregado como material de controle. No caso do ARC, os ensaios de módulo de resiliência foram realizados para os tempos de cura de 1 e 60 dias, enquanto que para o agregado natural, os períodos foram 1 e 90 dias. Esses resultados são apresentados nas Figuras 2.12, 2.13 e 2.14.

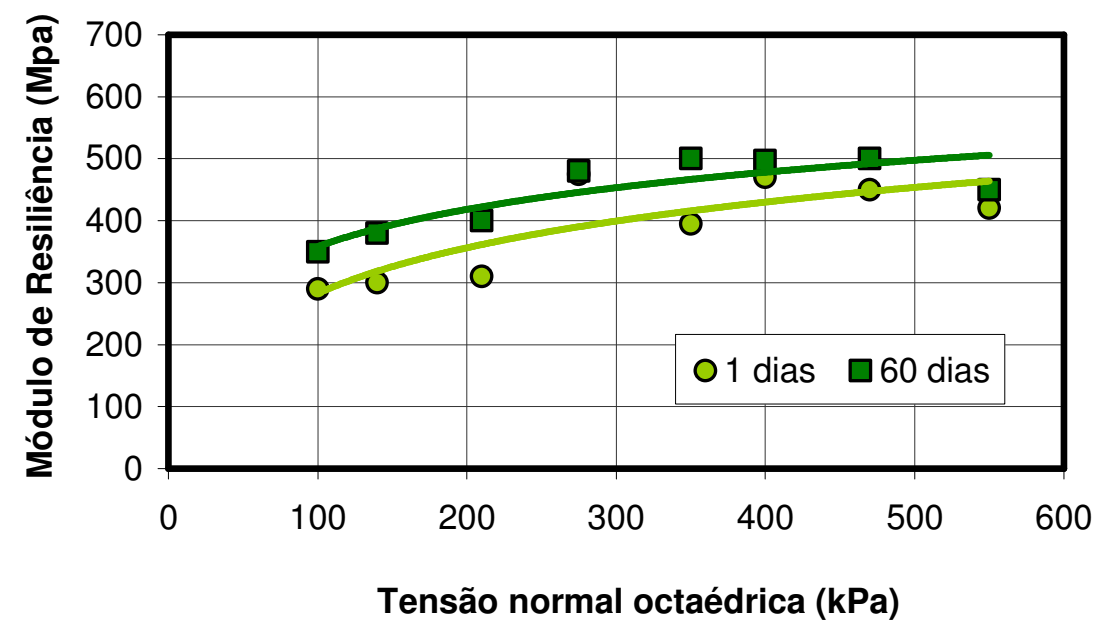

Figura 2.12 - Módulos de resiliência de agregados reciclados de concreto para tempos de cura de 1 e 60 dias (ARM, 2001).

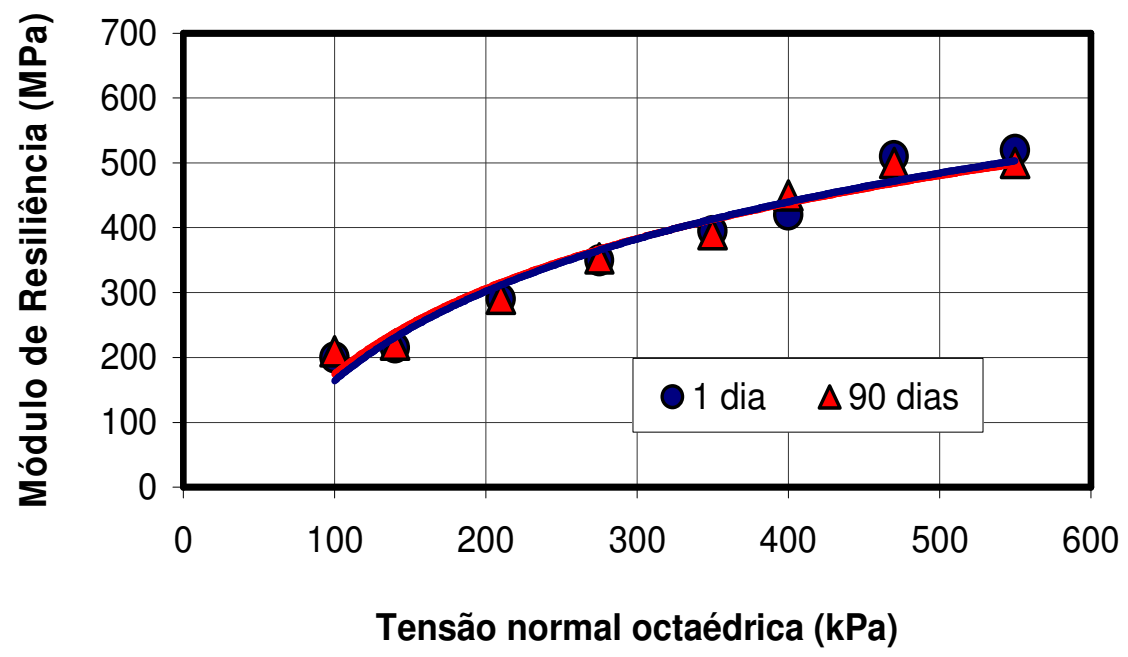

Figura 2.13 - Módulos de resiliência de agregados naturais para 1 e 90 dias de cura (ARM, 2001). 


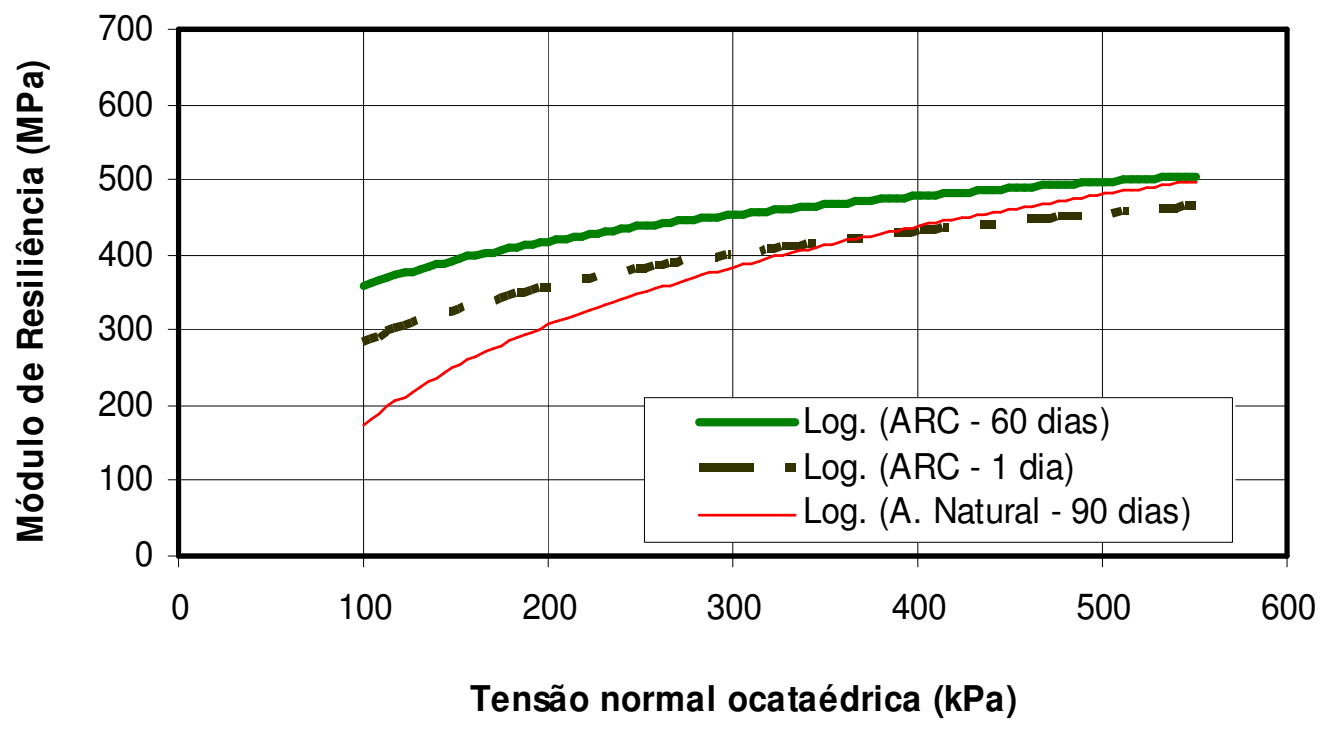

Figura 2.14 - Comparação do MR do agregado natural com os do ARC (ARM, 2001).

Analisando-se a Figura 2.12, verifica-se que o agregado reciclado de concreto apresentou um aumento de módulo de resiliência com o tempo para todos os níveis de tensão examinados. Observando-se a Figura 2.13, constata-se que o agregado natural, mesmo para um período de observação maior, noventa dias, não mostrou nenhum ganho de rigidez.

Na Figura 2.14, verifica-se que os valores de módulo de resiliência do agregado reciclado de concreto para o tempo de cura de 1 dia foram superiores ao do agregado natural (90 dias de cura) para tensões normais octaédricas inferiores a cerca de $350 \mathrm{kPa}$, já para tensões superiores, o agregado reciclado apresentou valores ligeiramente inferiores. Porém, quando se compara o ARC com 60 dias de cura com o agregado natural com 90 dias, observa-se que o agregado reciclado mostrou um comportamento resiliente superior para todos os níveis de tensão analisados. 


\section{MATERIAIS E MÉTODOS}

Neste capítulo são descritas as origens do agregado reciclado de concreto, do agregado natural e do solo, bem como os procedimentos de caracterização física e compactação utilizados para o desenvolvimento desta pesquisa. Em seguida, justificam-se a escolha das composições das misturas (ARC, ARC-solo, agregado natural) e a metodologia observada na preparação dos corpos-de-prova a serem ensaiados para determinação do comportamento mecânico. São também descritos os equipamentos e as técnicas que serão empregadas para execução dos ensaios de Î́ndice de Suporte Califórnia (CBR), Compressão Simples, Compressão Diametral e Triaxial Cíclico. Ao final, apresenta-se a metodologia para análise dos resultados experimentais.

\subsection{MATERIAIS UTILIZADOS}

\subsubsection{Agregado reciclado de concreto}

O agregado reciclado de concreto, também denominado por ARC, foi fornecido pela Usina de Reciclagem de Resíduos da Construção Civil de São Carlos - SP. Esta usina é administrada pela autarquia municipal PROHAB (Progresso e Habitação de São Carlos). 


\subsubsection{Operações da Usina de Reciclagem de São Carlos - SP}

As informações sobre as operações da Usina de Reciclagem de Resíduos da Construção Civil de São Carlos - SP descritas neste tópico foram baseadas no relatado por Fagury e Grande ( 2007).

O transporte dos resíduos de construção e demolição até a central de moagem é feito por caminhões com caçambas estacionárias. Os resíduos recebidos na usina são descarregados em montes de acordo com uma pré-seleção quanto à sua natureza, posteriormente passam por uma triagem manual, na qual são retirados os materiais contaminantes, como vidros, plásticos e metais.

Os resíduos de construção e demolição já triados, isto é, agrupados segundo sua constituição predominante em duas classes de resíduos, mistos e de concreto, são removidos e transportados com o auxílio de uma pá carregadeira até a primeira etapa da moagem que é feita por meio de um britador de mandíbulas. Depois da primeira etapa de britagem, esses resíduos são transportados por uma correia e depositados na parte superior de um silo metálico. Em seguida, os resíduos são britados novamente em um moinho de martelos. Por fim, os agregados constituídos predominante por resíduos de concreto e argamassa seguem por correias até um conjunto de peneiras, nas quais são separados de acordo com sua distribuição granulométrica em frações denominadas como "areia", "pedrisco", "brita 1". Observase que os resíduos mistos são apenas britados e lançados em uma pilha, sem passarem pela etapa de peneiramento, ou seja, são disponibilizados apenas na forma de "brita-corrida". A Figura 3.1 apresenta a seqüência das atividades 
executadas para a reciclagem dos resíduos de construção e demolição na usina de

São Carlos.

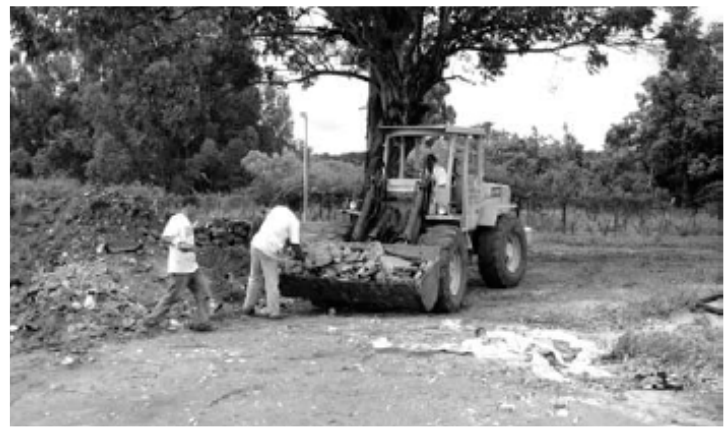

a) Atividade em área de triagem

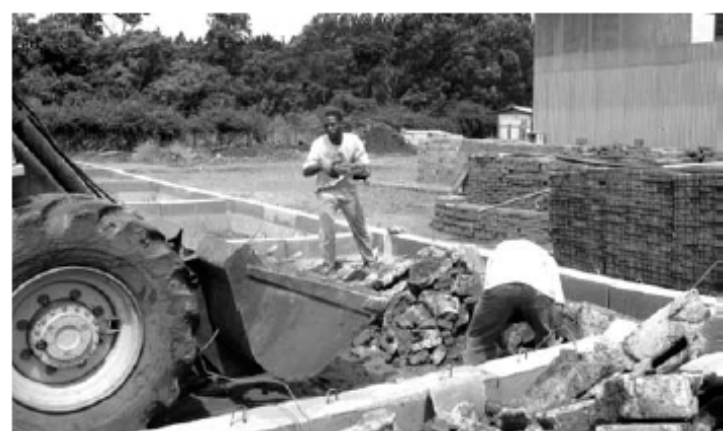

c) Detalhe das baias de material triado

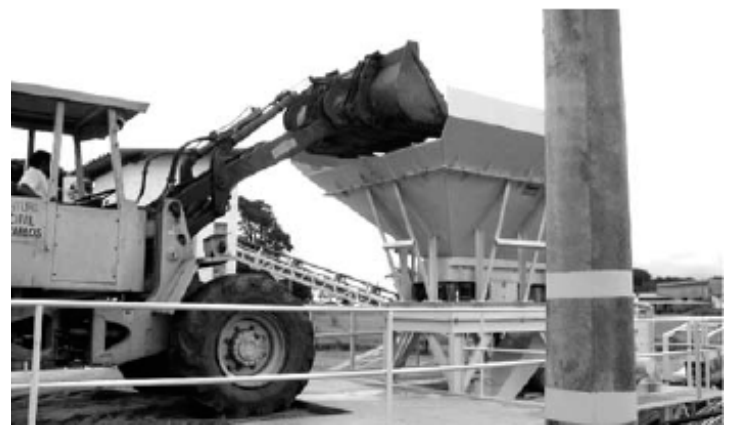

e) Lançamento de resíduos no alimentador

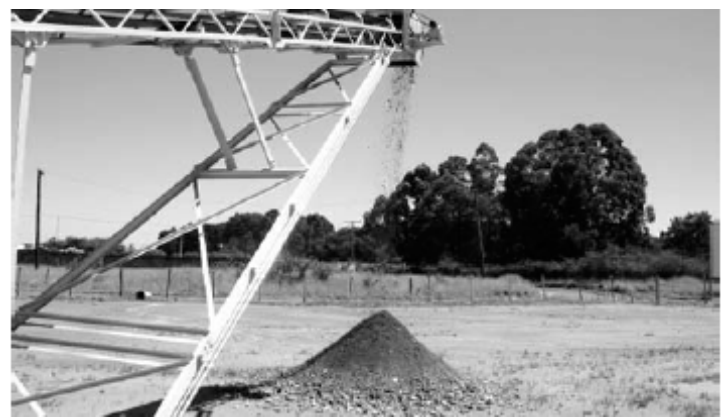

g) Lançamento do material britado sem peneiramento - "Brita Corrida"

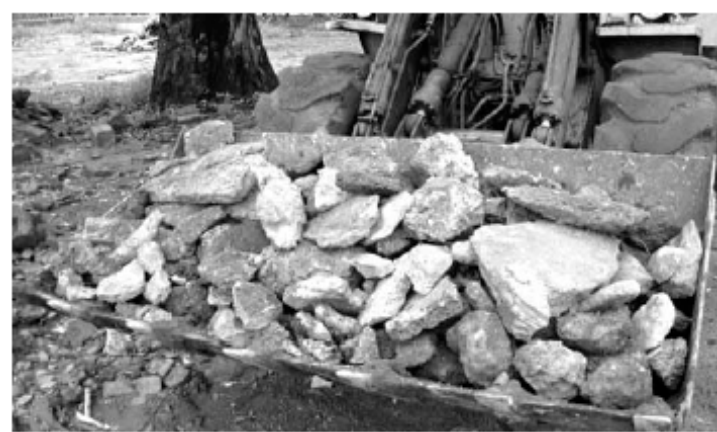

b) Detalhe do material triado

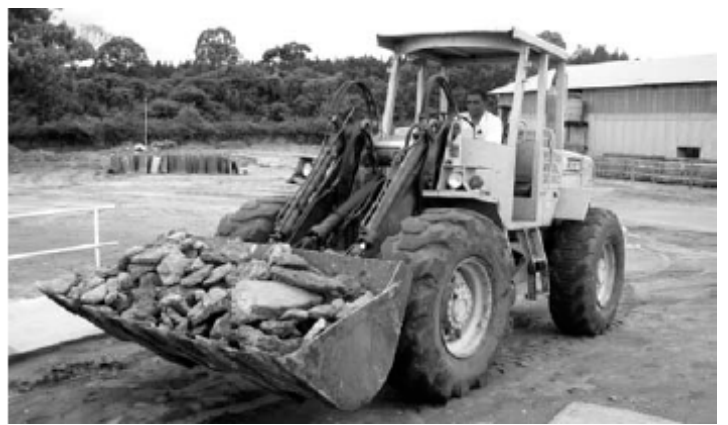

d) Transporte do material selecionado

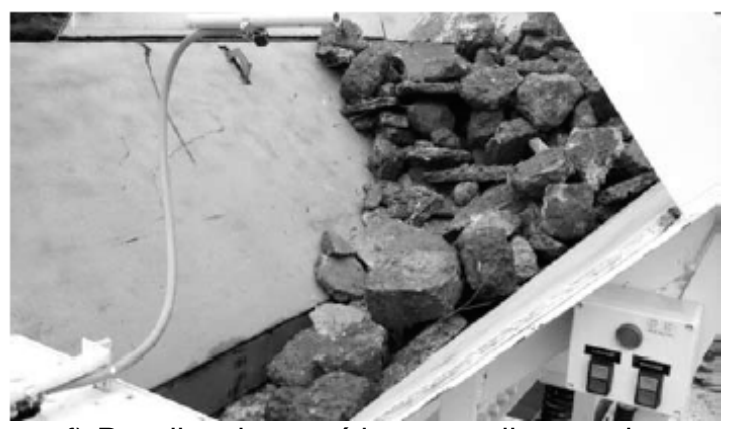

f) Detalhe dos resíduos no alimentador

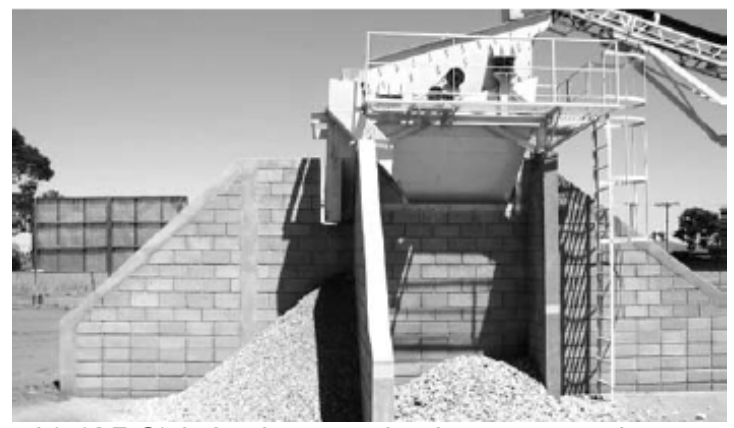

h) (ARC) britado, peneirado e separado em diferentes faixas granulométricas

Figura 3.1 - Seqüência de algumas atividades realizadas na Usina de Reciclagem de Resíduos de Construção Civil de São Carlos-SP (FAGURY; GRANDE, 2007). 
A produção da usina é de 20 toneladas por hora. Ao final de um ano são produzidas 36.960 toneladas de agregados reciclados, considerando uma jornada de 7 horas diária e 22 dias de trabalho por mês.

\subsubsection{Coleta}

A coleta do agregado reciclado de concreto foi realizada de acordo com a norma DNER PRO 120/97 “Coleta de Amostra de Agregados". Devido à possível variabilidade de sua composição ao longo do tempo, optou-se por coletar todo o material, cerca de duas toneladas, em um único dia. Após a coleta, o material foi transportado em sacos de $40 \mathrm{~kg}$ ao Laboratório de Estradas da EESC/USP.

\subsubsection{Distribuição granulométrica}

O agregado reciclado de concreto foi disponibilizados pela usina em três granulometrias distintas, denominadas por "brita 1", "pedrisco" e "areia". A análise granulométrica desses materiais foi realizada segundo o descrito na norma NBR 7181 "Solo - Análise granulométrica". A Figura 3.2 mostra as pilhas dos agregados na usina de reciclagem, enquanto a Figura 3.3 apresenta suas distribuições granulométricas. 


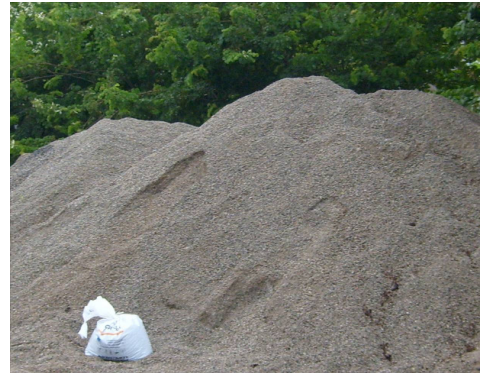

a) Pedrisco

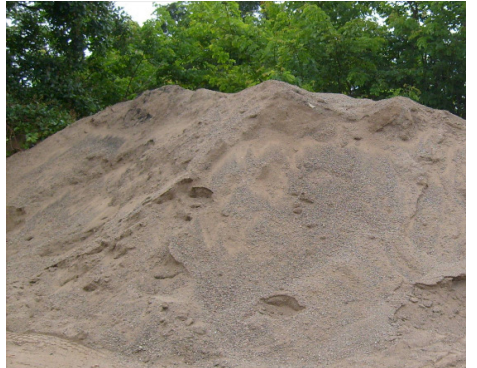

b) Areia

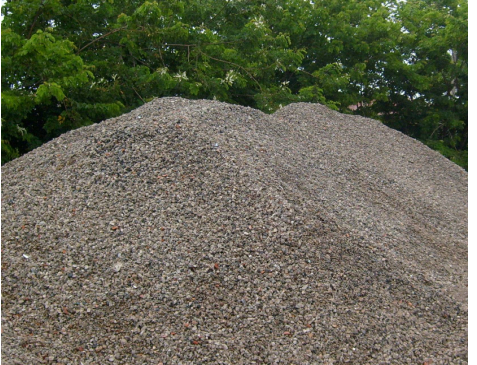

c) Brita 1

Figura 3.2 - Pilhas de agregado reciclado de concreto.

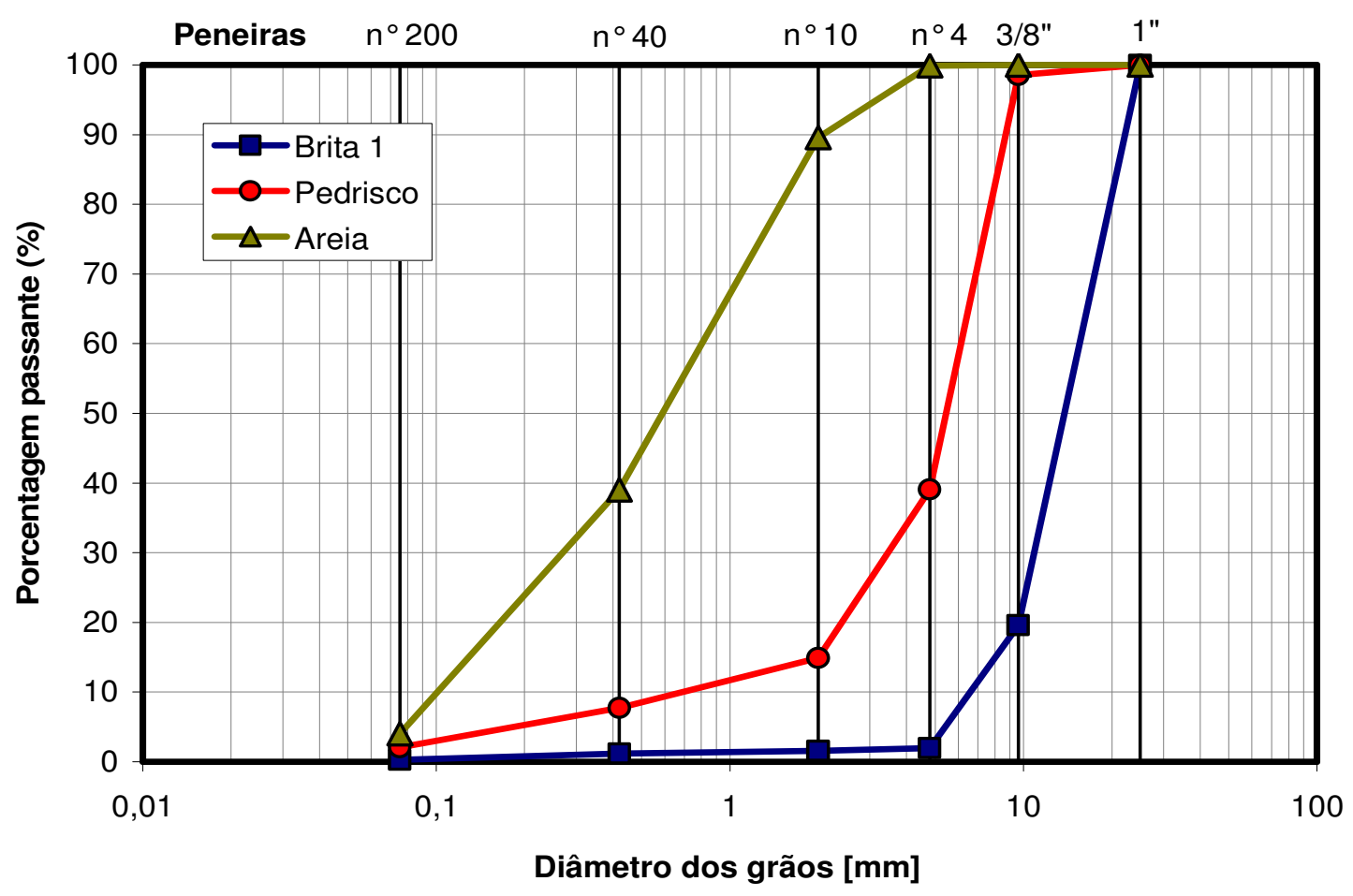

Figura 3.3 - Distribuições granulométricas das três graduações de ARC.

\subsubsection{Agregado natural}

O agregado natural, de origem basáltica, foi disponibilizado pela Pedreira Bandeirantes, localizada no município de São Carlos-SP, em duas granulometrias distintas, denominadas por "brita-corrida" e "pedrisco". Os procedimentos de coleta e 
de análise granulométrica foram semelhantes aos realizados para o agregado reciclado. A Figura 3.3 mostra as distribuições granulométricas destes agregados.

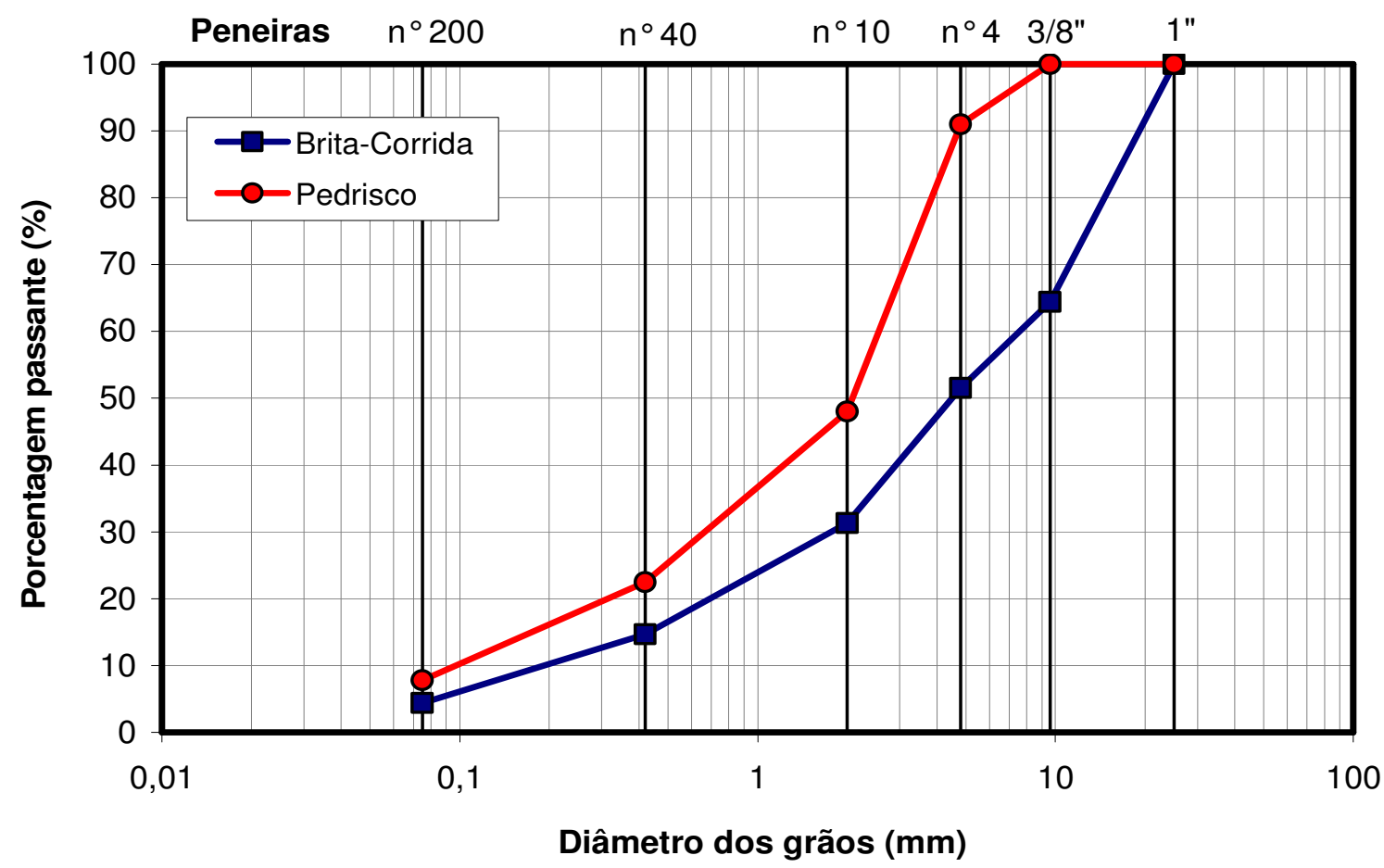

Figura 3.4 - Distribuições granulométricas das duas graduações de agregado natural.

\subsubsection{Solo}

O solo escolhido é proveniente de uma região próxima ao Município de São Carlos - SP. Este foi coletado de um talude da rodovia SP-304 (Rod. Dep. Leonidas Pacheco Ferreira), entre as cidades de Borborema e Ibitinga, no quilometro $384+$ $600 m$, acima da linha de seixos. A curva de distribuição granulométrica do solo é mostrada na Figura 3.5. 


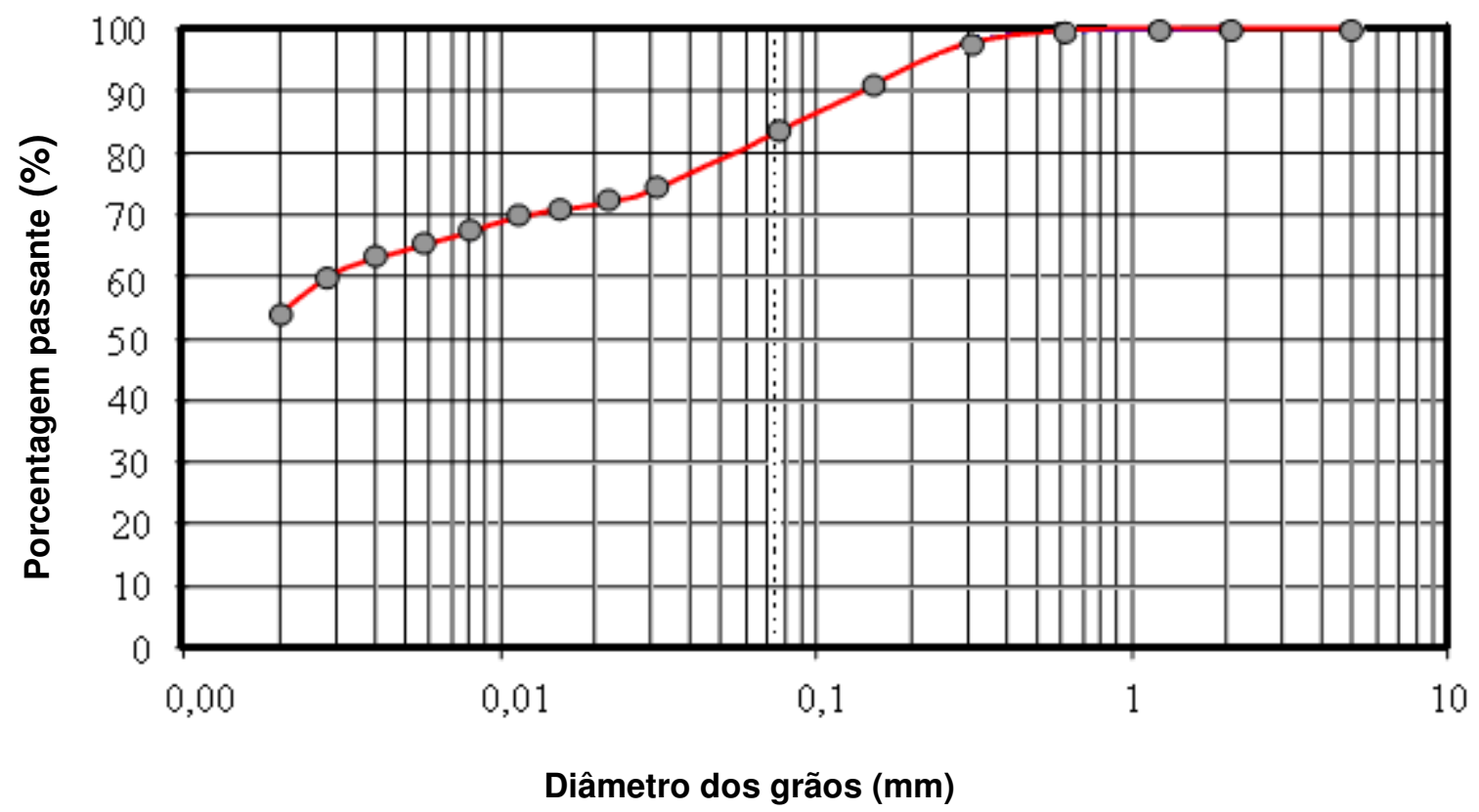

Figura 3.5 - Distribuição granulométrica do solo.

Após a coleta, o solo foi destorroado, peneirado e seco ao ar para depois ser homogeneizado e armazenado em sacos plásticos devidamente identificados.

\subsection{CARACTERIZAÇÃO E CLASSIFICAÇÃO DOS MATERIAIS}

\subsubsection{Agregados}

As características físicas dos materiais empregados em pavimentação estão intrinsecamente relacionadas à estabilidade que estes apresentarão quando sujeitos à ação imposta pelo clima e pelo tráfego de veículos. Nesta pesquisa, a caracterização dos agregados foi realizada com base nos ensaios de abrasão Los Angeles (DNER-ME 035/98) e absorção e densidade aparente de agregado graúdo (DNER-ME 81/98). Como um dos objetivos deste estudo é avaliar as características 
físicas do agregado reciclado de concreto e compará-las com as obtidas para 0 agregado natural, os resultados destes ensaios serão apresentados e discutidos no Capítulo 4.

\subsubsection{Solo}

O solo foi classificado de acordo com as classificações tradicionais, HRB (Highway Research Board) e USCS (Unified Soil Classification System), através de ensaios de análise granulométrica (NBR 7181/84), de limite liquidez (DNER-ME 122/94) e de limite de plasticidade (DNER-ME 82/94). Além disso, a massa específica dos sólidos foi determinada segundo o descrito na norma DNER-ME 93/64. Os resultados desses ensaios são mostrados na Tabela 3.1.

Tabela 3.1 - Resultados dos ensaios de massa específica dos grãos e limites de liquidez.

\begin{tabular}{cc}
\hline CARACTERÍSTICA & RESULTADO \\
\hline Limite de liquidez $(\%)$ & 50 \\
Índice de plasticidade $(\%)$ & 13 \\
Massa específica dos sólidos $\left(\mathrm{g} / \mathrm{cm}^{3}\right)$ & 2,928 \\
\hline
\end{tabular}

O solo foi classificado de acordo com a HRB como sendo um A-7-5, enquanto que pela USCS foi considerado como um ML.

Além de ser classificado pelas metodologias tradicionais, esse solo foi classificado segundo a metodologia MCT através dos ensaios de Mini-MCV e perda de peso por imersão de acordo com as normas descritas a seguir: 
- DNER-ME 256/94 - "Solos Compactados com Equipamento Miniatura

- Determinação da Perda de Massa por Imersão";

- DNER-ME 254/94 - "Solos Compactados em Equipamentos Miniatura - Mini-CBR e Expansão"

- DNER-CLA 259/96 - "Classificação de solos tropicais para finalidades rodoviárias utilizando corpos-de-prova compactados em equipamento miniatura".

O solo foi classificado pela metodologia MCT, conforme o apresentado na Figura 3.6, como sendo um solo de comportamento laterítico argiloso (LG').

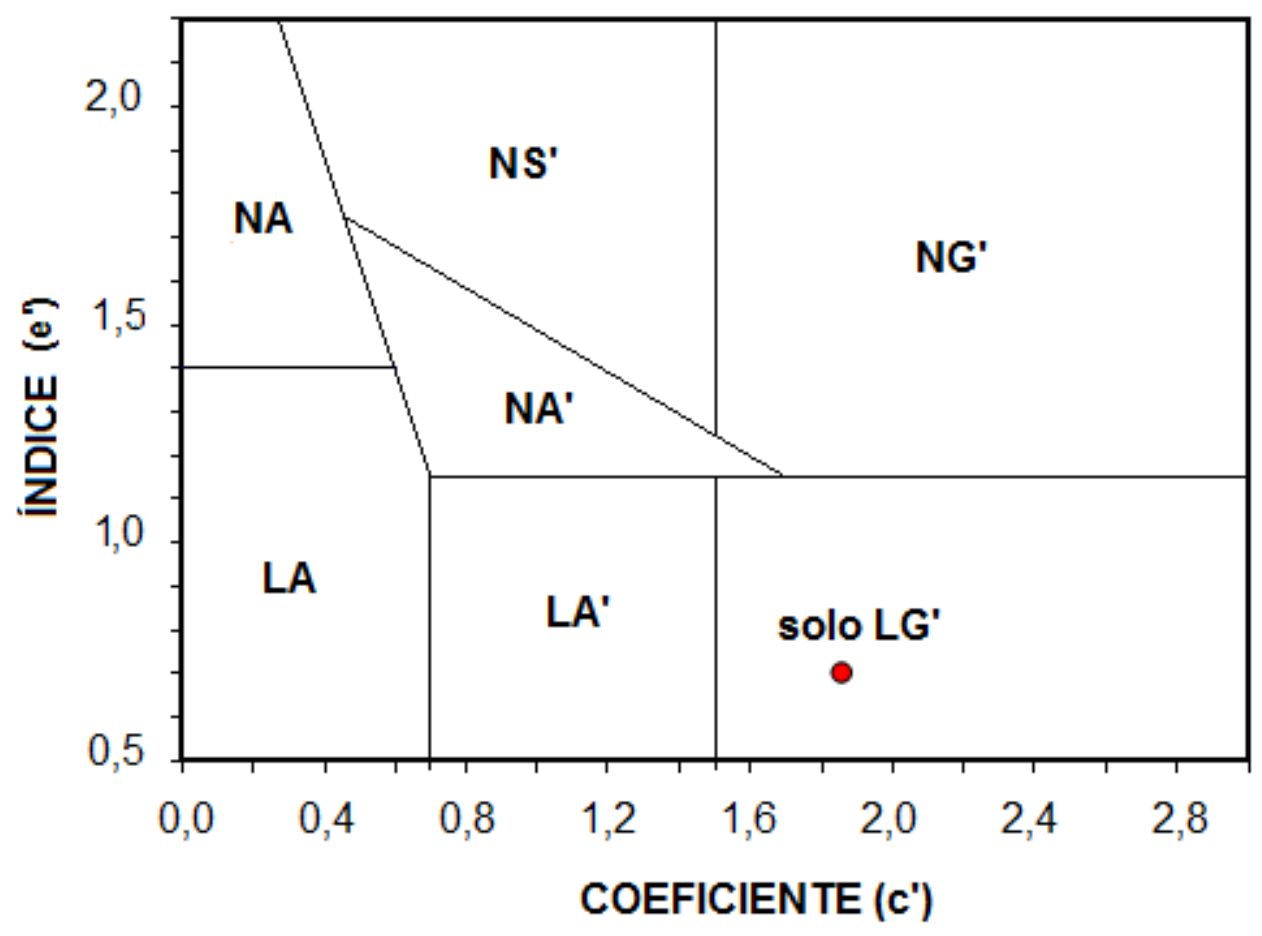

Figura 3.6 - Resultado da classificação MCT para o solo pesquisado. 


\subsection{ENSAIOS AMBIENTAIS}

Os ensaios de lixiviação e solubilização foram realizados, no Laboratório de Saneamento da EESC/USP, de acordo com normas NBR 10005/2004 "Lixiviação de resíduos sólidos" e NBR 10006/2004 "Solubilização de resíduos sólidos". Observase que o ensaio de lixiviação tem como finalidade identificar a concentração de substâncias que se separam do material por meio de lavagem e percolação, enquanto o ensaio de solubilização identifica a concentração das substâncias solúveis em água presentes no material. Esses dois ensaios são empregados no processo de classificação dos resíduos sólidos.

De acordo com a norma NBR 10004/2004 "Resíduos Sólidos - Classificação", a classificação de resíduos sólidos abrange a identificação do processo ou atividade que Ihes deu origem, de seus constituintes e características, e a comparação destes constituintes com listagens de resíduos e substâncias cujo impacto à saúde e ao meio ambiente é conhecido. Segundo esta norma os resíduos sólidos são classificados em dois grupos, Classe I - perigosos e Classe II - não perigosos, sendo esse último grupo subdivido em Classe II A - não inertes e Classe II B inertes.

\subsection{COMPOSIÇÃO DAS MISTURAS}

\subsubsection{Composição dos agregados}

A norma NBR 15115 "Agregados reciclados de resíduos sólidos da construção civil - Execução de camadas de pavimentação - Procedimentos" (ABNT, 
2004e) não especifica faixas granulométricas para o emprego deste material. Contudo, prevê que alguns aspectos devem ser verificados, tais como porcentagem de material passante na peneira de 0,42mm, dimensão característica máxima dos grãos e coeficiente de uniformidade $\left(C_{u}\right)$, cujos limites são apresentados na Tabela 3.2.

Tabela 3.2 - Aspectos normativos referentes à granulometria de agregados reciclados (NBR 15115).

\begin{tabular}{ccc}
\hline PARÂMETRO & LIMITES & UNIDADE \\
\hline Dimensão característica máxima dos grãos & 63,5 & $\mathrm{~mm}$ \\
Porcentagem passante na peneira de 0,42 $\mathrm{mm}$ & 10 a 40 & $\%$ \\
Cu - Coeficiente de Uniformidade & $\geq 10$ & - \\
\hline
\end{tabular}

A dimensão característica máxima dos grãos é definida como a abertura da peneira em que fica retida uma porcentagem acumulada igual ou imediatamente inferior a 5\%, em massa. Já o coeficiente de uniformidade indica o quão bemgraduado ou mal-graduado é o material, sendo quanto maior seu valor mais bemgraduado é considerado o material. Esse índice pode ser obtido conforme o apresentado na Equação 3.1 .

$$
C_{u}=\frac{d_{60}}{d_{10}}
$$

onde:

$\mathrm{C}_{\mathrm{u}}$ : coeficiente de uniformidade;

$\mathrm{d}_{10}$ : diâmetro correspondente a $10 \%$ de porcentagem passante $(\mathrm{mm})$; $d_{60}$ : diâmetro correspondente a $60 \%$ de porcentagem passante $(\mathrm{mm})$.

Uma vez que a norma de agregados reciclados não preconiza faixas granulométricas, as três frações granulométricas do agregado reciclado de concreto 
foram proporcionadas de maneira que a mistura se enquadrasse o mais próximo possível da faixa C da norma DNER ES 303/97. A composição da mistura de agregados reciclados de concreto, em massa, foi de $40 \%$ de areia, $30 \%$ de pedrisco e $30 \%$ de brita 1 . A mistura de agregados naturais foi dosada de maneira que se enquadrasse dentro da mesma faixa granulométrica, resultando em uma composição, em massa, de $75 \%$ de brita-corrida e $25 \%$ de pedrisco.

As distribuições granulométricas das misturas e os limites especificados pela faixa C são mostrados na Tabela 3.3 e na Figura 3.7.

Tabela 3.3 - Distribuições granulométricas das misturas proporcionadas.

\begin{tabular}{ccccc}
\hline \multirow{2}{*}{$\begin{array}{c}\text { PENEIRAS } \\
(\mathbf{m m})\end{array}$} & \multicolumn{4}{c}{ PORCENTAGEM PASSANTE (\%) } \\
\cline { 2 - 5 } & \multicolumn{2}{c}{ AGREGADO } & \multicolumn{2}{c}{ LIMITES FAIXA C } \\
& RECICLADO & NATURAL & INFERIOR & SUPERIOR \\
\hline 25,0 & 100 & 100 & 100 & 100 \\
9,53 & 75 & 73 & 50 & 85 \\
4,76 & 52 & 61 & 35 & 65 \\
2,00 & 41 & 35 & 25 & 50 \\
0,42 & 18 & 17 & 15 & 30 \\
0,074 & $2^{*}$ & 5 & 5 & 15 \\
\hline
\end{tabular}

${ }^{*}$ Abaixo do valor especificado para faixa C pela norma DNER ES 303/97.

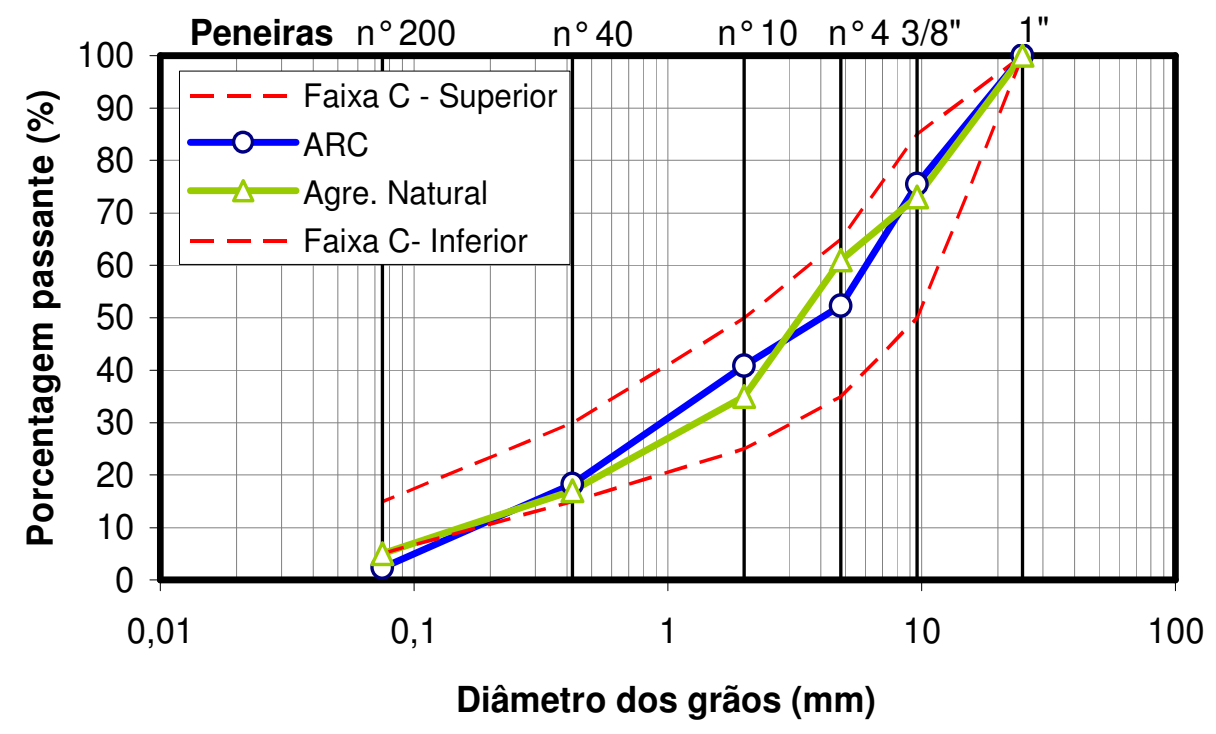

Figura 3.7 - Distribuições granulométricas das misturas proporcionadas. 
A Tabela 3.4 apresenta os parâmetros obtidos da distribuição granulométrica do agregado reciclado de concreto.

Tabela 3.4 - Parâmetros obtidos da distribuição granulométrica do ARC.

\begin{tabular}{cc}
\hline PARÂMETRO & RESULTADO ARC \\
\hline Dimensão máxima característica $(\mathrm{mm})$ & 25 \\
Porcentagem passante na peneira $0,42 \mathrm{~mm}(\%)$ & 18 \\
Coeficiente de uniformidade & 33 \\
\hline
\end{tabular}

Analisando-se a Tabela 3.4 e a Figura 3.7, observa-se que a curva granulométrica de projeto do agregado natural se enquadra na faixa $\mathrm{C}$ especificada pela norma DNER ES 303/97. Já a curva granulométrica do ARC, embora tenha se localizado próxima à região central desta faixa, apresenta uma carência de partículas finas, passantes na peneira de número 200 , apenas $2 \%$, enquanto a norma supracitada preconiza um mínimo passante de 5\%. Entretanto, comparandose os resultados do agregado reciclado de concreto apresentados na Tabela 3.4 com os exigidos pela norma NBR 15115 (Tabela 3.2), constata-se que o ARC atende a todos os requisitos de granulometria.

\subsubsection{Composição da mistura ARC-solo}

As proporções, em massa, do agregado reciclado de concreto e do solo na mistura foram de $75 \%$ e $25 \%$, respectivamente, sendo que o ARC foi composto por 1/3 de cada fração granulométrica (brita 1, pedrisco e areia). Salienta-se que a porcentagem escolhida de solo é um valor usual em misturas solo-agregado. Além disso, observa-se que a curva granulometria da mistura se enquadra na faixa $D$ da norma DNER ES 303/97. Os resultados obtidos da curva de projeto juntamente com os limites especificados pela faixa D são mostrados na Figura 3.8. 


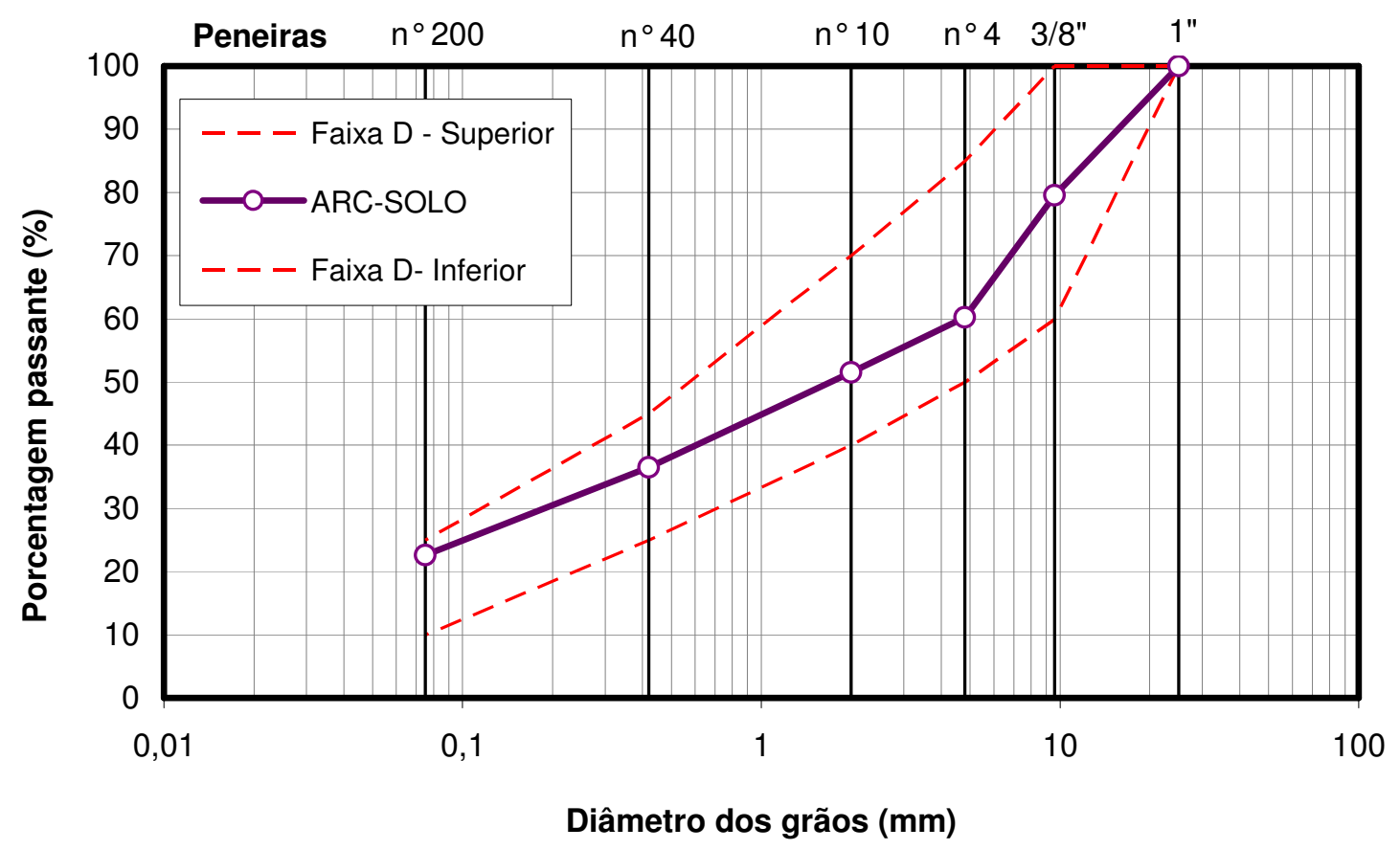

Figura 3.8 - Distribuição granulométrica da mistura ARC-solo.

\subsection{ENSAIOS DE COMPACTAÇÃO}

Os ensaios de compactação foram conduzidos para a determinação dos valores de massa específica seca máxima $\left(\rho_{\mathrm{dmax}}\right)$ e umidade ótima $\left(\omega_{\mathrm{o}}\right)$ das misturas pesquisadas. Esses ensaios foram realizados de acordo com o descrito na norma NBR 7182/84 "Solo - Ensaio de compactação".

O agregado reciclado de concreto foi compactado em duas energias, intermediária e modificada. A opção pela energia intermediária foi devido ao fato da norma NBR 15115 (ABNT, 2004e) recomendar no mínimo essa energia para execução de camadas de bases de pavimentos. Já a energia modificada foi escolhida em função de ser a mais empregada em pesquisas internacionais. Os demais materiais geotécnicos (mistura ARC-solo, solo, agregado natural) foram compactados apenas na energia modificada. Para os agregados reciclados e para 
os naturais, os ensaios foram realizados sem reaproveitamento de material e com escalpe da fração retida na fração de 19 mm, com substituição por igual quantidade de material passante nessa peneira e retido na peneira de $4,8 \mathrm{~mm}$.

\subsection{DEGRADAÇÃO DO AGREGADO RECICLADO DE CONCRETO}

A degradação de um material pode ser analisada através da comparação das curvas granulométricas antes e depois de sua compactação. Para avaliação da degradação do agregado reciclado de concreto, utilizou-se uma amostra compactada na energia modificada, moldada na condição de massa específica seca máxima e umidade ótima. Após a compactação, o corpo-de-prova foi desmoldado suavemente, destorroado e peneirado para a realização do novo ensaio de peneiramento.

\subsection{ENSAIOS DE CBR E DE COMPORTAMENTO MECÂNICO}

A avaliação do desempenho dos materiais empregados nesta pesquisa foi realizada por meio de ensaios de Índice de Suporte Califórnia (CBR), compressão simples, compressão diametral e triaxial cíclico para a determinação do módulo de resiliência, todos realizados no Laboratório de Estradas da EESC/USP.

\subsubsection{Ensaio de Índice de Suporte Califórnia (CBR)}

O ensaio de Índice de Suporte Califórnia, também denominado por CBR (California Bearing Ratio), de maneira resumida, consiste na aplicação de um 
carregamento estático em um corpo-de-prova sob condição saturada. Este ensaio é realizado em três etapas, moldagem do corpo-de-prova, imersão em água por um período de quatro dias, e penetração no corpo-de-prova por um pistão de diâmetro padronizado, em velocidade constante, acompanhado do registro das cargas de reação, conforme ilustram as Figuras 3.9 a 3.11.

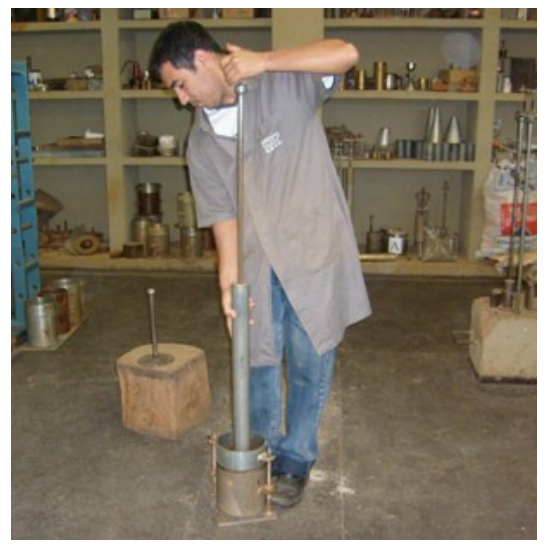

Figura 3.9 - Compactação de corposde-prova de CBR.

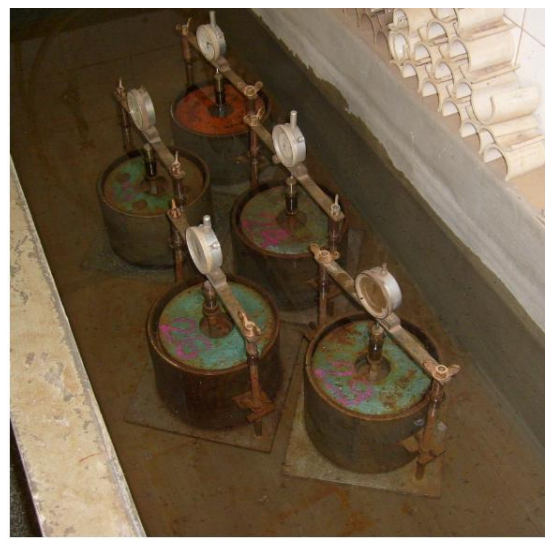

Figura 3.10 - Imersão de corposde-prova de CBR.

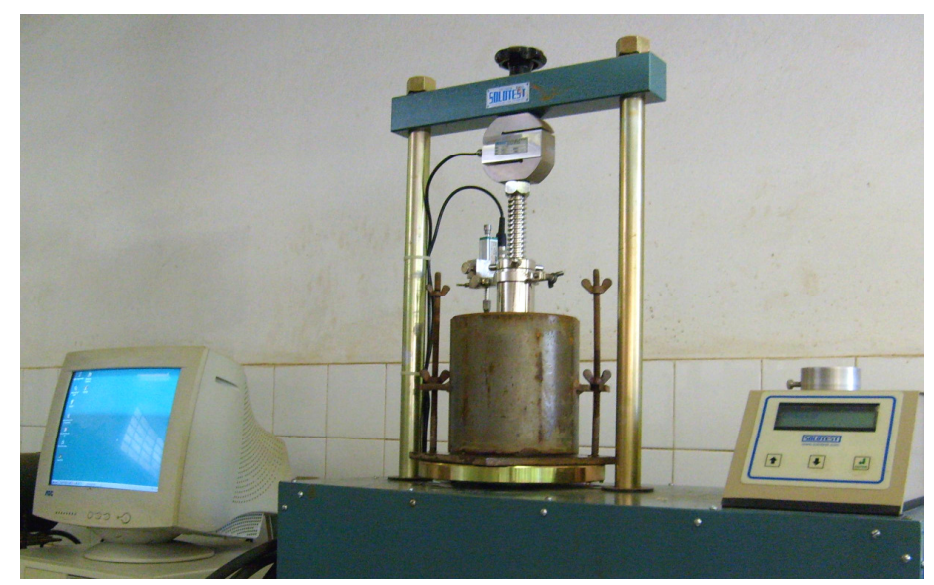

Figura 3.11 - Prensa empregada para penetração dos corpos-de-prova de CBR.

O ensaio de CBR foi realizado conforme o especificado pela norma DNER-ME 049/94. A penetração dos corpos-de-prova foi realizada na prensa apresentada Figura 3.11, cuja capacidade é de $5000 \mathrm{~kg}$ e a velocidade de aplicação de carga é 
controlada. Para o ensaio de CBR, a velocidade de penetração empregada foi de $1,27 \mathrm{~mm} / \mathrm{min}$.

\subsubsection{Moldagem dos Corpos-de-prova}

As amostras de material para moldagem dos corpos-de-prova para os ensaios de compressão simples, compressão diametral e triaxial cíclico foram preparadas conforme as proporções apresentadas no item 3.4. A cada amostra adicionava-se água suficiente para se atingir a umidade desejada, em seguida, o material era homogeneizado e embalado em saco plástico. As amostras úmidas eram deixadas por 24 horas em câmara úmida para uniformização de sua umidade. Após esse período, realizavam-se os procedimentos de compactação.

A escolha das dimensões dos corpos-de-prova do ensaio triaxial e compressão simples foi baseada na granulometria dos materiais empregados nesta pesquisa. De acordo com a norma DNER 131/94 "Solos - Determinação do Módulo de Resiliência", o diâmetro do corpo-de-prova deve ser no mínimo igual a quatro vezes o diâmetro máximo dos grãos a ser ensaiado e sua altura deve ser de no mínimo duas vezes o diâmetro. Em virtude do diâmetro máximo dos agregados ser de $25 \mathrm{~mm}$, as dimensões dos corpos-de-prova empregados nos ensaios de compressão simples e triaxial cíclico foram de $10 \mathrm{~cm}$ de diâmetro por $20 \mathrm{~cm}$ de altura. Os corpos-de-prova utilizados no ensaio de compressão diametral tiveram dimensões próximas às observadas em misturas asfálticas, adotou-se um diâmetro de $10 \mathrm{~cm}$ e uma altura de 7,86 cm. A Figura 3.12 e 3.13 ilustra exemplos de corposde-prova moldados. 


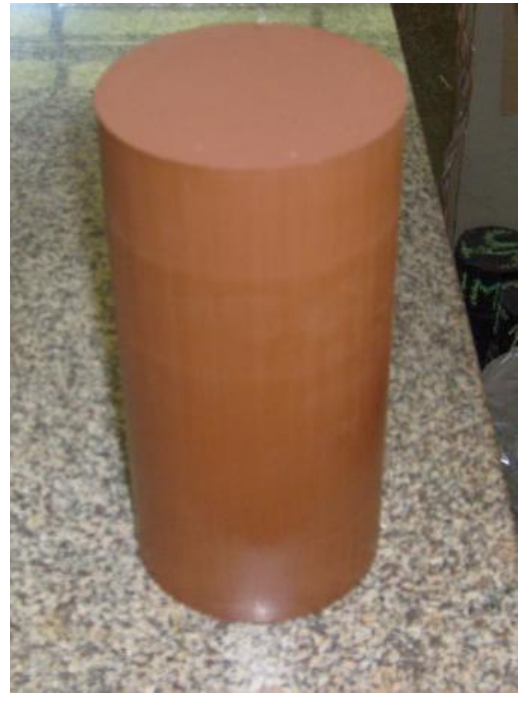

Figura 3.12 - Corpo-de-prova de $10 \times 20 \mathrm{~cm}$.

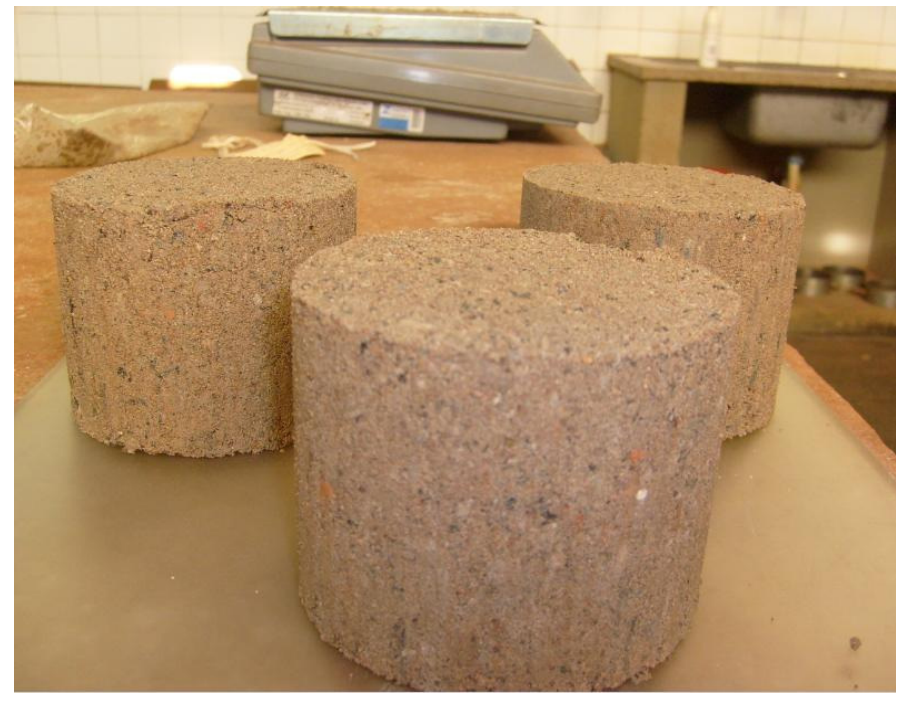

Figura 3.13 - Corpo-de-prova de 10x7,86cm.

A compactação dos corpos-de-prova empregados no ensaio de compressão simples e triaxial foi realizada em cinco camadas, já a compactação dos corpos-deprova empregados no ensaio de compressão diametral foi realizada em apenas uma camada. Observa-se que os corpos-de-prova foram moldados estaticamente na condição de umidade ótima $\left(w_{\circ}\right)$ e massa específica seca máxima $\left(\rho_{d m a x}\right)$. Na Figura 3.14, é apresentada a prensa hidráulica utilizada e nas Figuras 3.15 e 3.16 são mostrados o cilindros empregados para a compactação das amostras de $10 \times 20 \mathrm{~cm}$ e $10 \times 7,86 \mathrm{~cm}$, respectivamente. 


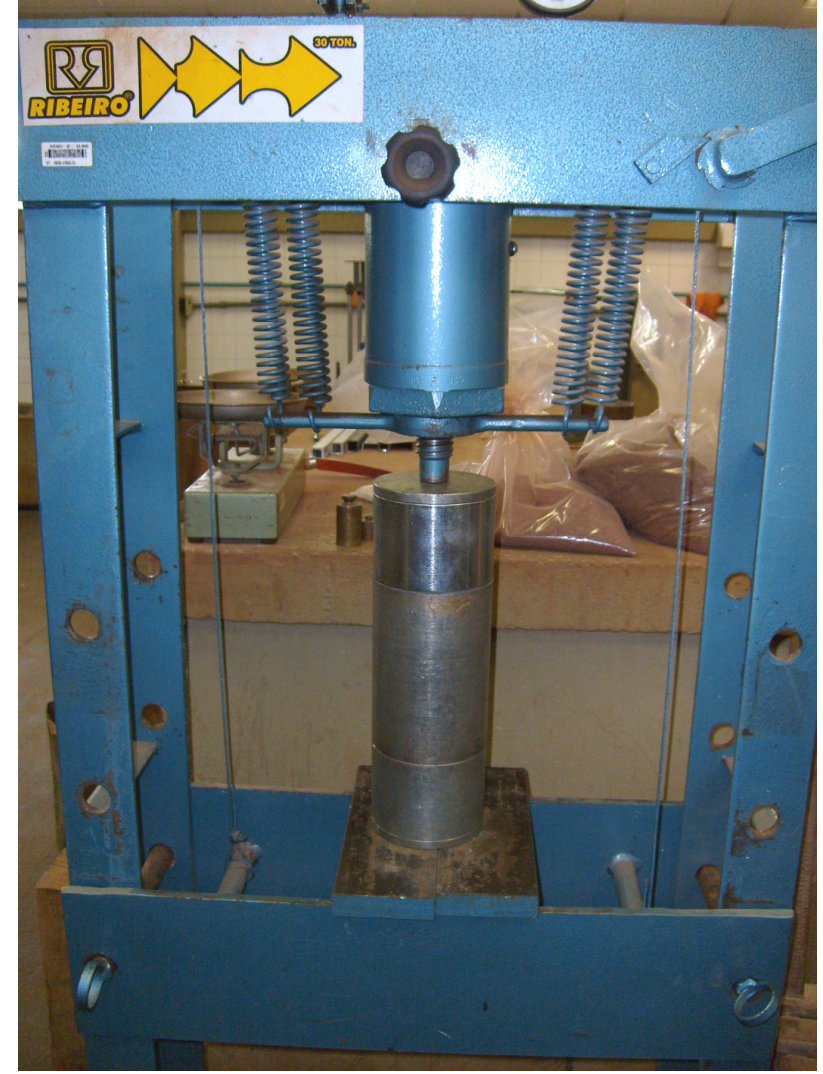

Figura 3.14 - Prensa empregada para moldagem dos corpos-de-prova.

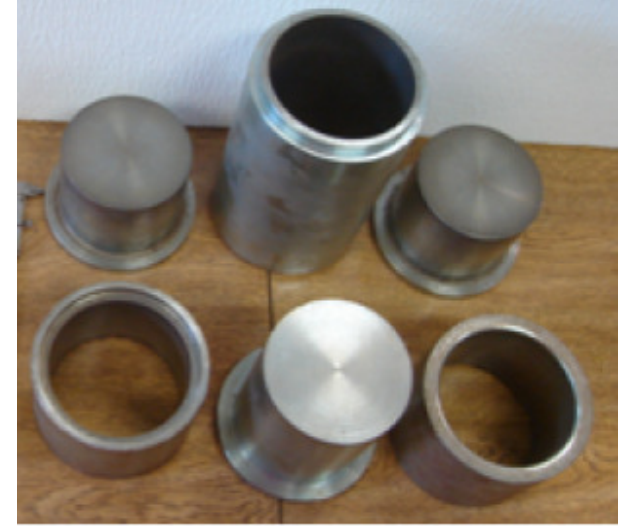

Figura 3.15 - Cilindros empregados na moldagem dos corpos-de-prova de $10 \times 20 \mathrm{~cm}$.

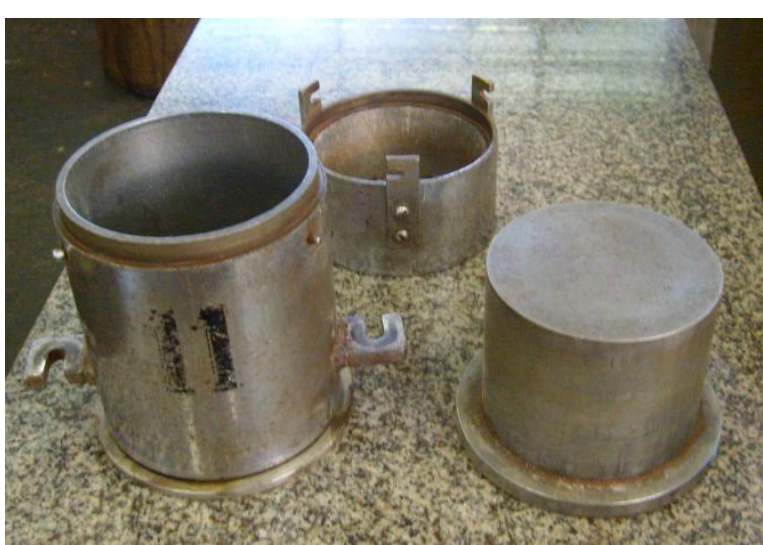

Figura 3.16 - Cilindros empregados na moldagem dos corpos-de-prova de $10 \times 7,86 \mathrm{~cm}$.

A desmoldagem dos corpos-de-prova foi feita com o auxílio de um macaco hidráulico, mostrado na Figura 3.17. Em seguida, determinava-se a massa da amostra para se obter o grau de compactação (GC). Observa-se que foram aceitos corpos-de-prova que apresentaram grau de compactação situado entre 99\% e 
101\%. Posteriormente, os corpos-de-prova eram envolvidos com filme plástico e identificados, conforme ilustrado na Figura 3.18. Por último, esses eram armazenados em câmara úmida até o momento do ensaio para que se evitasse a perda da umidade.

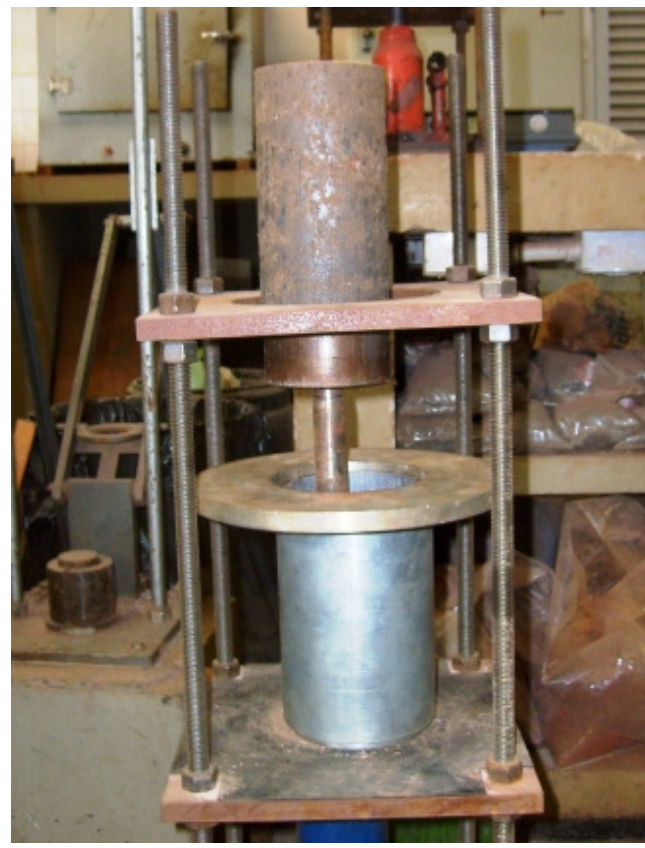

Figura 3.17 - Desmoldagem dos corpos de prova.

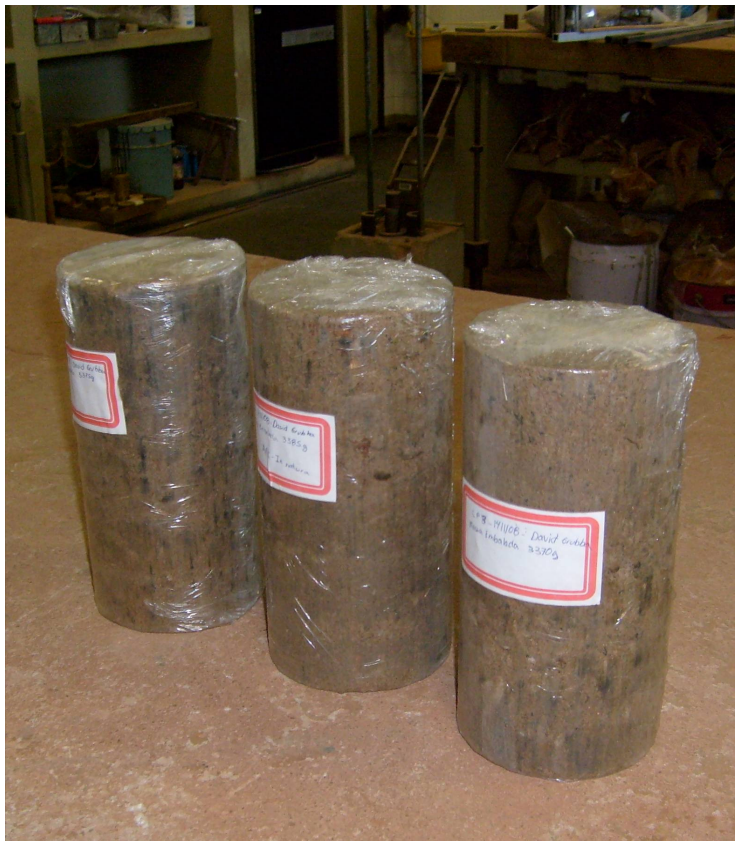

Figura 3.18 - Corpos-de-prova selados.

No tocante ao tempo de cura, os ensaios de compressão simples do agregado reciclado de concreto foram realizados para os tempos de cura de $0,3,7$, 28 e 90 dias, para os ensaios de compressão diametral foram realizados ensaios para os mesmos períodos, com exceção de 90 dias, já para a determinação do módulo de resiliência foram examinados apenas dois tempos de cura, 0 e 90 dias. Observa-se que para os demais materiais não foi analisada a influência do tempo de cura. 
Destaca-se que para os ensaios de compressão simples e diametral foram compactados três corpos-de-prova por condição pesquisada. Já para o ensaio triaxial, em função de sua maior dificuldade de execução, compactou-se apenas um corpo-de-prova por condição. Acredita-se que este procedimento não acarreta problemas de confiabilidade, visto que o ensaio triaxial cíclico apresenta boa repetibilidade tanto para ensaios realizados no mesmo corpo-de-prova quanto para os realizados em corpos-de-prova diferentes (PARREIRA et al., 1998).

Após a realização dos ensaios, os corpos-de-prova eram desmanchados e colocados em estufa para a determinação de suas umidades. Foram aceitos os resultados de corpos-de-prova que apresentaram uma umidade com variação máxima de até $0,5 \%$ em torno da umidade ótima.

\subsubsection{Ensaio de Compressão Simples}

No ensaio de compressão simples, utilizou-se a mesma prensa empregada no ensaio de CBR e a mesma velocidade de aplicação $(1,27 \mathrm{~mm} / \mathrm{min})$. Os deslocamentos dos corpos-de-prova foram medidos com o uso de um LVDT (Linear Variable Differential Transducer). Através de um sistema de aquisição automática, os deslocamentos e as cargas medidos em $\mathrm{mm}$ e em $\mathrm{kgf}$, respectivamente, eram armazenados para uso posterior. Uma vista de um corpo-de-prova sendo ensaiado no equipamento é mostrada na Figura 3.19. 


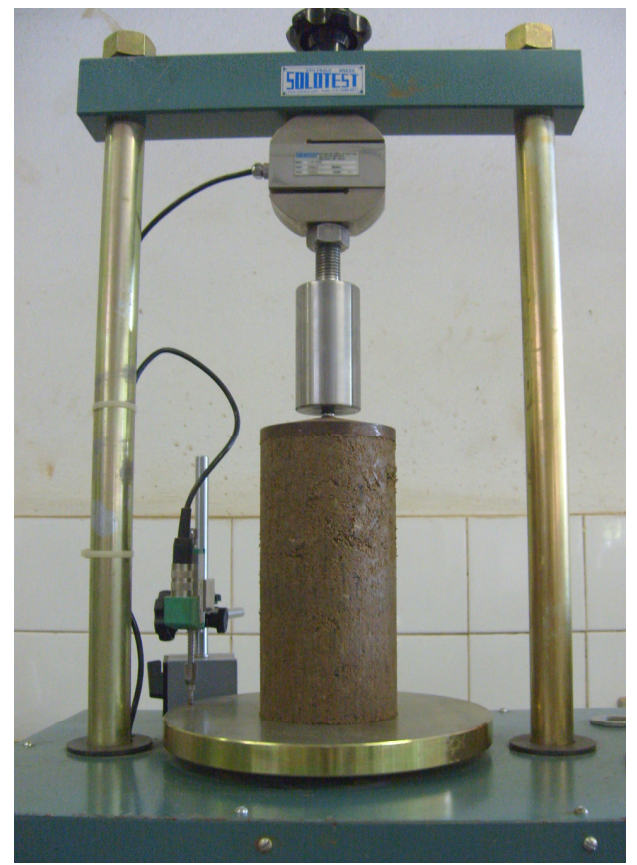

Figura 3.19 - Ensaio de compressão simples.

Por meio deste ensaio, analisou-se a resistência à compressão simples e o módulo tangente a $50 \%$ da tensão de ruptura $\left(\mathrm{E}_{\mathrm{TAN}, 50 \%}\right)$ das amostras, conforme esquematizado na Figura 3.20.

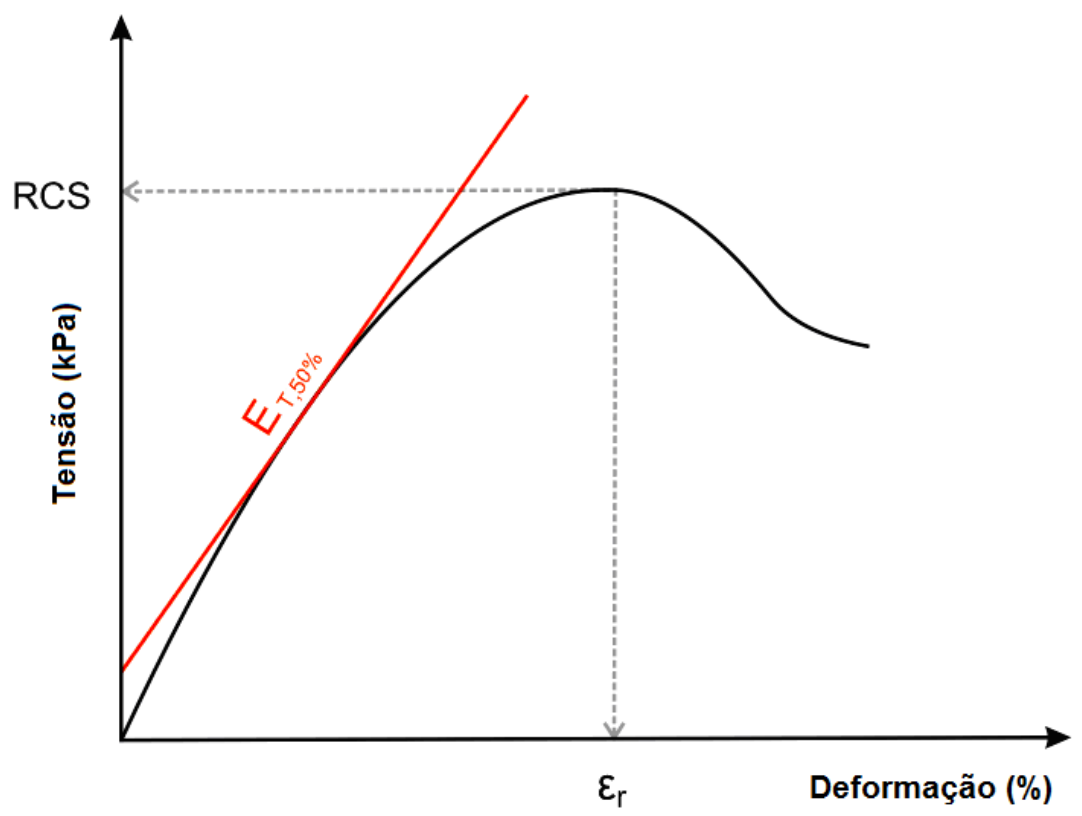

Figura 3.20 - Parâmetros avaliados no ensaio de compressão simples. 


\subsubsection{Ensaio de Compressão Diametral}

O ensaio de compressão diametral, ou tração indireta, foi desenvolvido por Lobo Carneiro e Barcellos, no Brasil, para determinar a resistência à tração de corpos-de-prova de concreto com cimento Portland. Atualmente, esse ensaio é empregado em larga escala na avaliação do comportamento mecânico de misturas asfálticas. Algumas pesquisas utilizam esse ensaio também para avaliar a resistência à tração de misturas de solos/ agregados estabilizados com cimento ou cal. Consiste em ensaiar o corpo-de-prova sem confinamento com uma carga de compressão ao longo de um plano diametral aplicada através de dois frisos de carga opostos, conforme o ilustrado na Figura 3.21.

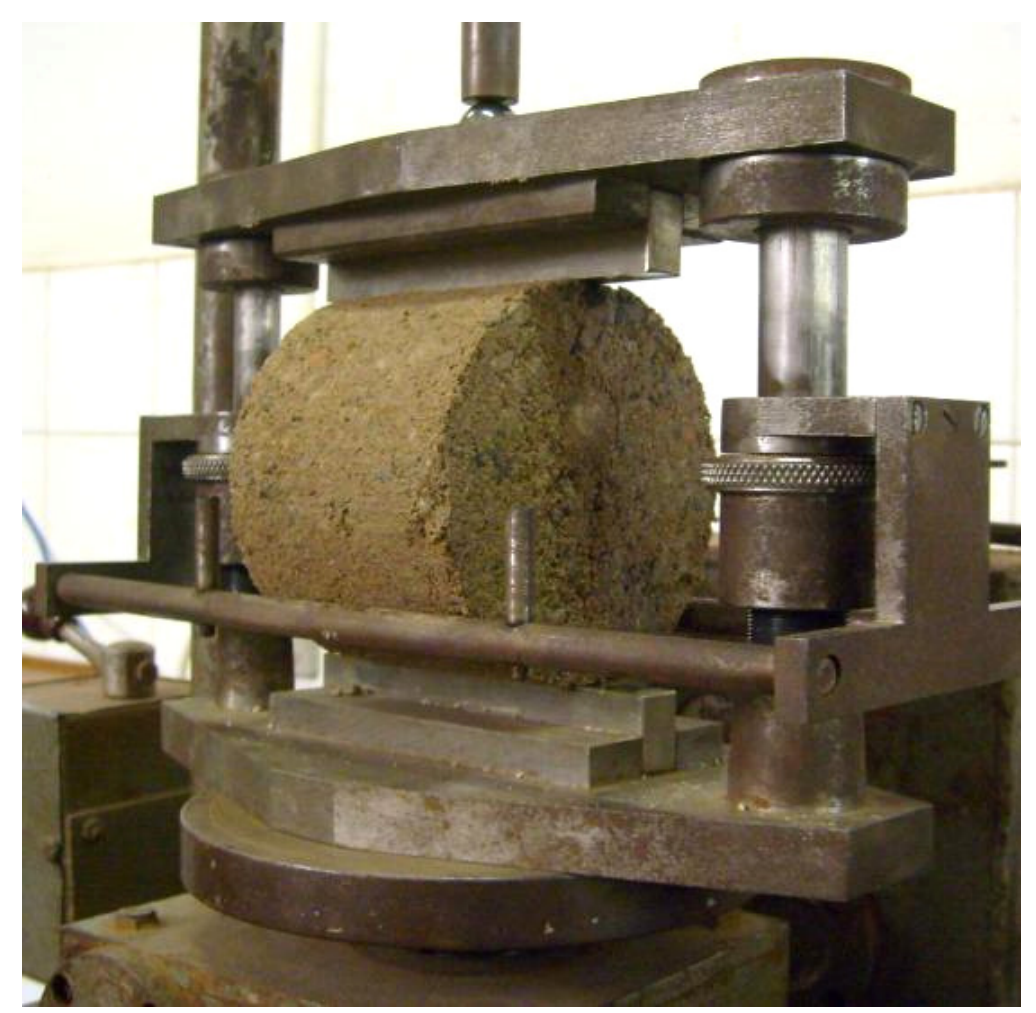

Figura 3.21 - Rompimento de um corpo-de-prova no ensaio de compressão diametral. 
O valor da resistência à tração por compressão diametral (RTCD) é definido como uma relação entre a força de ruptura e as características geométricas do corpo-de-prova (diâmetro e altura). Esse parâmetro pode ser calculado de acordo com a Equação 3.2.

$$
R T C D=\frac{2 \times F}{\pi \times D \times H}
$$

Onde:

RTCD = Resistência à tração por compressão diametral;

$\mathrm{F}=$ Carga de Ruptura;

$\mathrm{D}=$ Diâmetro do corpo-de-prova;

$\mathrm{H}=$ Altura do corpo-de-prova.

Os ensaios foram realizados no equipamento mostrado na Figura 3.22, na mesma velocidade do ensaio de compressão simples e CBR.

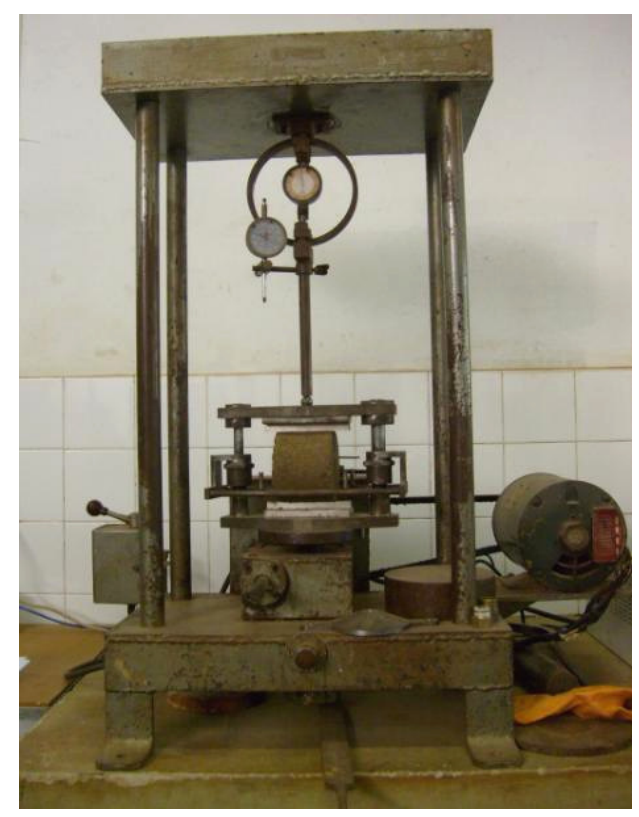

Figura 3.22 - Prensa empregada no ensaio de compressão diametral. 


\subsubsection{Ensaio Triaxial Cíclico}

O ensaio triaxial cíclico foi realizado segundo o descrito na norma "Standart Method of Test for Determining the Resiliente Modulus of Soils and Aggregate Materials" (AASHTO Designation: T 307-99), visando à determinação do módulo de resiliência (MR).

Os ensaios triaxiais cíclicos foram realizados em duas etapas de aplicação de carga. A primeira é a fase de condicionamento da amostra, cuja finalidade é eliminar as deformações permanentes que ocorrem nas primeiras aplicações de carregamento e também reduzir o efeito do histórico de tensões no valor do módulo de resiliência. Já na segunda fase, os deslocamentos resilientes são propriamente medidos.

A norma AASHTO T 307-99 estabelece que o ensaio triaxial cíclico deva ser realizado em 16 fases para materiais empregados em base e sub-base de pavimentos. Na primeira fase de condicionamento, são aplicados entre 500 a 1000 ciclos de carregamento, sendo a tensão desvio $\left(\sigma_{d}\right)$ igual a $93,1 \mathrm{kPa}$ e a tensão de confinamento $\left(\sigma_{3}\right)$ igual a $103,4 \mathrm{kPa}$. As 15 fases seguintes são destinadas às leituras das deformações, com $\sigma_{d}$ variando de 31 a $248,2 \mathrm{kPa}$ e $\sigma_{3}$ variando de 20,7 a 137,9 kPa. A Tabela 3.5 apresenta a seqüência de tensões empregadas por este método. 
Tabela 3.5 - Tensões empregadas no ensaio triaxial cíclico (AASHTO T 307-99).

\begin{tabular}{|c|c|c|c|c|c|}
\hline $\begin{array}{c}\text { SEQÜÊNCIA } \\
\text { No }\end{array}$ & $\begin{array}{c}\text { TENSÃO } \\
\text { CONFINANTE } \\
\sigma_{3}(\mathrm{kPa})\end{array}$ & $\begin{array}{r}\text { TENSÃO } \\
\text { MÁXIMA } \\
\sigma_{\mathrm{a}}(\mathrm{kPa})\end{array}$ & $\begin{array}{c}\text { TENSÃO DE } \\
\text { CONTATO } \\
\sigma_{\mathrm{c}}(\mathrm{kPa})\end{array}$ & $\begin{array}{l}\text { TENSÃO } \\
\text { DESVIO } \\
\sigma_{d}(k P a)\end{array}$ & $\begin{array}{l}\text { NÚMERO DE } \\
\text { APLICAÇÕES } \\
\text { DE CARGA }\end{array}$ \\
\hline 0 & 103,4 & 103,4 & 10,3 & 93,1 & $500-1000$ \\
\hline 1 & 20,7 & 20,7 & 2,1 & 78,6 & 100 \\
\hline 2 & 20,7 & 41,4 & 4,1 & 37,3 & 100 \\
\hline 3 & 20,7 & 62,1 & 6,2 & 55,9 & 100 \\
\hline 4 & 34,5 & 34,5 & 3,5 & 31,0 & 100 \\
\hline 5 & 34,5 & 68,9 & 6,9 & 62,0 & 100 \\
\hline 6 & 34,5 & 103,4 & 10,3 & 93,1 & 100 \\
\hline 7 & 68,9 & 68,9 & 6,9 & 62,0 & 100 \\
\hline 8 & 68,9 & 137,9 & 13,8 & 124,1 & 100 \\
\hline 9 & 68,9 & 206,8 & 20,7 & 186,1 & 100 \\
\hline 10 & 103,4 & 68,9 & 6,9 & 62,0 & 100 \\
\hline 11 & 103,4 & 103,4 & 10,3 & 93,1 & 100 \\
\hline 12 & 103,4 & 206,8 & 20,7 & 196,1 & 100 \\
\hline 13 & 137,9 & 103,4 & 10,3 & 93,1 & 100 \\
\hline 14 & 137,9 & 137,9 & 13,8 & 124,1 & 100 \\
\hline 15 & 137,9 & 275,8 & 27,6 & 248,2 & 100 \\
\hline
\end{tabular}

Neste experimento, foi utilizado o equipamento triaxial cíclico do Laboratório de Estradas da EESC/USP, apresentado na Figura 3.23. Este possui um sistema de carregamento pneumático, no qual a tensão desvio e as tensões confinantes são controladas por computador através de válvulas proporcionais e os deslocamentos do corpo-de-prova são medidos com o auxílio de dois LVDTs. A célula de carga, da marca GEFRAN, com capacidade de carga de $5,0 \mathrm{kN}$, é posicionada internamente à câmara triaxial.

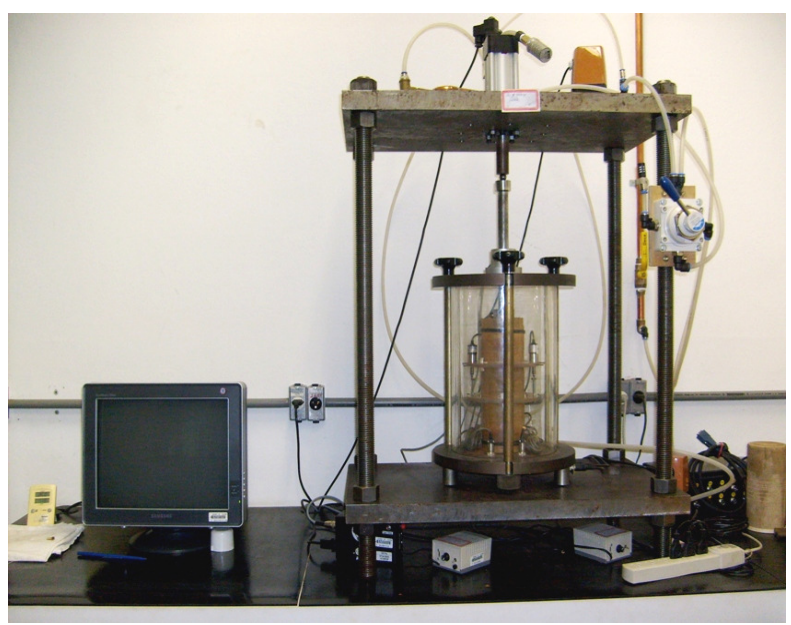

Figura 3.23 - Equipamento triaxial cíclico - Laboratório de Estradas da EESC/USP. 
A obtenção de dados foi realizada por meio de um programa desenvolvido, em plataforma LabView, pelo Prof. Dr. Glauco Tulio Pessa Fabbri. A Figura 3.24 apresenta uma tela fornecida pelo programa. Esse programa permite a leitura de três canais individuais, nos quais são adquiridas as informações sobre os dois deslocamentos e a carga cíclica. Assim, é possível determinar a carga cíclica efetivamente aplicada em cada ciclo do carregamento e os deslocamentos resultantes. O deslocamento resiliente de cada ciclo é obtido pela média dos deslocamentos registrados em cada LVDT.

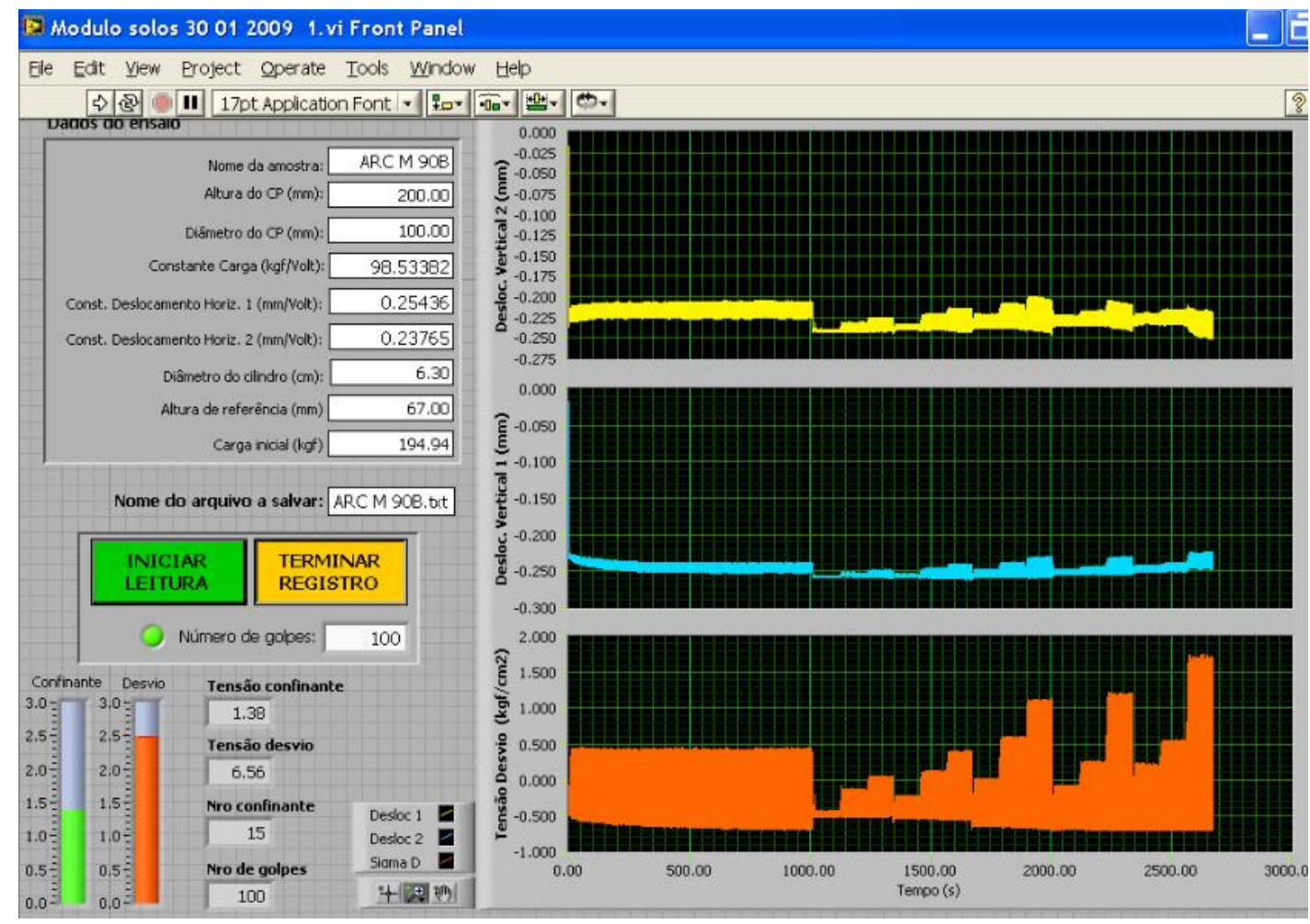

Figura 3.24 - Detalhe da saída do programa de aquisição de dados do ensaio triaxial cíclico.

\subsubsection{Análise dos Resultados}

As análises dos resultados dos ensaios de compressão simples e compressão diametral foram feitas com base nos valores estatísticos de média e desvio padrão; sendo aplicado o teste de Grubbs para identificação de outliers 
(GRUBBS, 1969). No Capítulo 4, serão apresentados apenas os valores médios destes ensaios, enquanto nos Anexos II e III serão apresentados, respectivamente, os resultados completos dos ensaios de compressão simples e compressão diametral.

Para aplicação do teste de Grubbs, deve-se verificar que os dados podem ser razoavelmente representados por uma distribuição normal. O teste de Grubbs é definido pelas seguintes hipóteses: hipótese nula $\left(\mathrm{H}_{0}\right)$, não existe nenhum outlier nos resultados dos ensaios; hipótese alternativa $\left(H_{1}\right)$, existe pelo menos um outlier nos resultados dos ensaios. Este teste pode detectar apenas um outlier a cada vez que é realizado. $\mathrm{O}$ outileir é eliminado dos dados e repete-se o teste até que não sejam detectados outliers. Para a utilização deste teste, deve-se verificar dentre os dados de um mesmo tratamento quais são os valores máximo e mínimo e, a partir destes valores, calcular o valor estatístico G definido pela equação:

$$
G=\max \left(\frac{Y_{i}-\bar{Y}}{s}\right)
$$

Onde:

$Y_{i}=$ valores máximo e mínimo dentro do mesmo conjunto de resultados;

$\bar{Y}=$ média dos resultados de um mesmo tratamento;

$\mathrm{S}=$ desvio padrão dos resultados de um mesmo tratamento.

O valor estatístico $G$ deve ser comparado com o valor $G_{\text {critico }}$ que depende do número de repetições $(\mathrm{N})$ e grau de confiança $(\alpha)$. O resultado é considerado um outlier quando $G>G_{\text {critico. }}$. Para esta pesquisa adotou-se nível de confiança de $95 \%$ e foram feitas três observações para cada ensaio, sendo o $G_{\text {crítico }}$ utilizado 1,15 . 


\section{APRESENTAÇÃO E ANÁLISE DOS RESULTADOS}

\subsection{CONSIDERAÇÕES INICIAIS}

Neste capítulo são apresentados e analisados os resultados dos ensaios de caracterização, compactação, degradação, Índice de Suporte Califórnia, resistência à compressão simples, resistência à compressão diametral e triaxial cíclico a que foram submetidos os materiais estudados nesta pesquisa.

\subsection{CARACTERIZAÇÃO FíSICA DOS AGREGADOS}

A Tabela 4.1 apresenta um resumo das características físicas do agregado reciclado de concreto e do agregado natural empregados nesta pesquisa. Nesta tabela, são relatados apenas os valores médios dos ensaios, enquanto no Anexo I são mostrados todos os resultados.

Tabela 4.1 - Características físicas dos agregados.

\begin{tabular}{cccc}
\hline \multirow{2}{*}{ CARACTERÍstICAS } & \multicolumn{2}{c}{ TIPO DE AGREGADOS } \\
& & ARC & AG. NATURAL \\
\hline \multirow{2}{*}{ Abrasão Los Angeles (\%) } & Graduação B & 35 & 19 \\
Absorção do agregado graúdo (\%) & 33 & 22 \\
Densidade aparente do agregado graúdo & 4,6 & 2,4 \\
\hline
\end{tabular}


Analisando-se a Tabela 4.1, verifica-se que o valor de absorção de água encontrado para o agregado reciclado de concreto nesta pesquisa, 4,6\%, está em conformidade com a faixa de valores típicos relatados por Saeed et al (2007). De acordo com estes pesquisadores, este parâmetro varia entre $2 \%$ e $6 \%$.

Observa-se ainda que a absorção do ARC foi cerca de duas vezes maior do que à do agregado natural. Acredita-se que essa diferença seja devida à presença de argamassa aderida aos grãos, uma vez que a porosidade de argamassas é bem superior a verificada em materiais pétreos. Entretanto, quando se comparam os agregados reciclados de concreto com os agregados mistos, verifica-se que os valores de absorção dos agregados reciclados de concreto são bem inferiores. Por exemplo, Leite (2007) relata que a absorção do agregado reciclado misto oriundo do Município de Santo Andre-SP foi de 12,2\%, enquanto Motta (2005) encontrou uma absorção de 7,8\% para o proveniente do Município de São Paulo-SP.

Analisando-se a densidade aparente dos agregados graúdos, grãos retidos na peneira de $4,8 \mathrm{~mm}$, verifica-se que a densidade do agregado reciclado de concreto, 2,403, é $14 \%$ inferior à observada no agregado natural, 2,783.

No tocante à resistência à abrasão Los Angeles, constata-se que o agregado reciclado de concreto apresentou desgaste superior ao verificado para o natural. Considerando as duas graduações ensaiadas, observa-se que a resistência à abrasão média do ARC foi de $34 \%$, enquanto a do agregado natural foi de $21 \%$. 
A norma NBR 15115 (ABNT, 2004e) não menciona a resistência à abrasão Los Angeles como requisito para a utilização de agregados reciclados de resíduos de construção civil em pavimentação. Porém, a especificação DNER-ES 303/97 especifica que o desgaste de materiais empregados na estabilização granulométrica de bases deve ser inferior a 55\%. Nesta pesquisa, tanto o agregado reciclado de concreto quanto o agregado natural apresentaram valores bem inferiores ao máximo especificado por esta última norma.

A Figura 4.1 (a) ilustra uma amostra molhada de ARC enquadrada na graduação B do ensaio de resistência à abrasão Los Angeles antes da execução do ensaio, enquanto a Figura 4.1 (b) apresenta a mesma amostra após a execução do ensaio. A molhagem das amostras se deu para facilitar a visualização dos diferentes materiais presentes nos agregados reciclados de concreto.

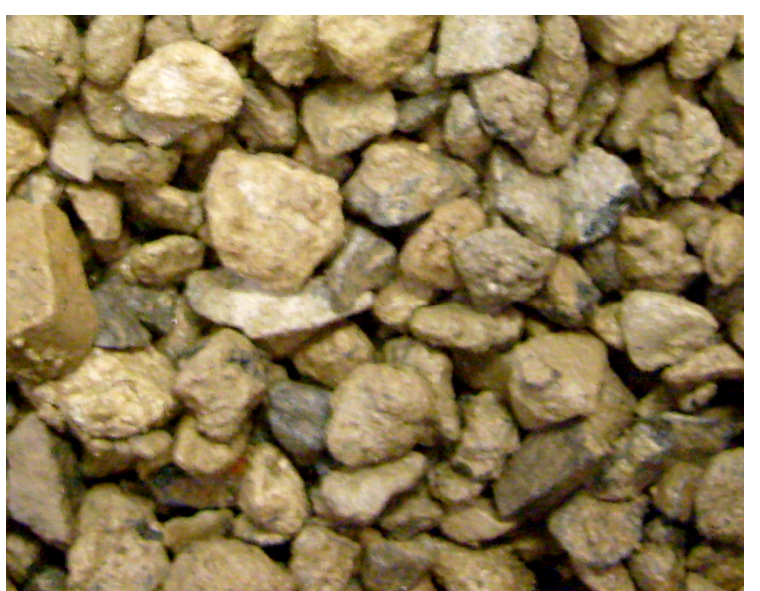

(a) Amostra molhada de ARC antes do ensaio

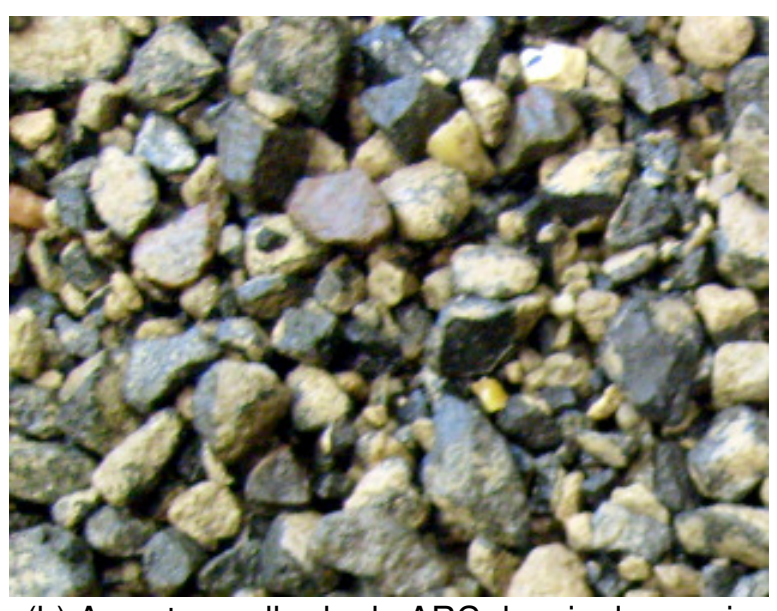

(b) Amostra molhada de ARC depois do ensaio

Figura 4.1 - Avaliação da presença de argamassa aderida aos grãos antes e depois do ensaio de abrasão Los Angeles.

Analisando-se a Figura 4.1, é possível observar que a presença de argamassa/ pasta de cimento recobre boa parcela dos grãos antes da execução do 
ensaio, e depois do ensaio, recobre apenas uma pequena parcela destes. Dessa forma, acredita-se que a diferença de desgaste entre o agregado reciclado e o natural se dê em grande parte em função da presença de argamassa / pasta de cimento, fracamente aderida aos grãos de $A R C$, que durante a execução do ensaio se desprende.

A Tabela 4.2 mostra alguns resultados de ensaios de abrasão Los Angeles de agregados reciclados de concreto e de agregados reciclados mistos encontrados na revisão bibliográfica nacional, confrontados com os resultados determinados nesta pesquisa.

Tabela 4.2 - Comparação de resultados de abrasão Los Angeles de agregados reciclados de concreto com agregados reciclados mistos.

\begin{tabular}{cccc}
\hline $\begin{array}{c}\text { AGREGADO } \\
\text { RECICLADO }\end{array}$ & FONTE & $\begin{array}{c}\text { GRADUAÇÃO } \\
\text { DE ENSAlO }\end{array}$ & $\begin{array}{c}\text { ABRASÃO LOS } \\
\text { ANGELES (\%) }\end{array}$ \\
\hline \multirow{3}{*}{ Misto } & Fernandes (2004) & A & 55 \\
& Fernandes (2004) & B & 66 \\
& Motta (2005) & B & 50 \\
\hline \multirow{4}{*}{ Concreto } & Fernandes (2004) & A & 52 \\
& Oliveira (2007) & B & 33 \\
\cline { 2 - 4 } & Oliveira (2007) & C & 36 \\
\cline { 2 - 4 } & Esta pesquisa & B & 35 \\
\hline
\end{tabular}

Examinando-se a Tabela 4.2, verifica-se que a composição dos agregados reciclados de resíduos de construção e demolição influencia diretamente nos resultados de abrasão Los Angeles. Os agregados reciclados de concreto apresentam, em geral, menor desgaste do que os agregados reciclados mistos. Além disso, é possível observar que os resultados encontrados nesta pesquisa são próximos aos relatados por Oliveira (2007). 


\subsection{ENSAIOS AMBIENTAIS}

Conforme já mencionado no Capítulo 3 - Materiais e Métodos, os ensaios de lixiviação e solubilização foram realizados no Laboratório de Saneamento da EESC/USP, de acordo com o descrito nas normas NBR 10005/2004 "Lixiviação de resíduos de resíduos sólidos" e NBR 1006/2004 "Solubilização de resíduos sólidos".

Os resultados dos ensaios de lixiviação e solubilização são apresentados nas Tabelas 4.3 e 4.4, respectivamente.

Tabela 4.3 - Resultados do ensaio de lixiviação do agregado reciclado de concreto.

\begin{tabular}{ccccc}
\hline PARÂMETRO & UNIDADE & $\begin{array}{c}\text { LIMITE DE } \\
\text { DETECÇÃO (LD) }\end{array}$ & $\begin{array}{c}\text { LIMITE MÁXIMO } \\
\text { NO EXTRATO }\end{array}$ & ARC \\
\hline Arsênio & $\mathrm{mg} \mathrm{As} \cdot \mathrm{L}-1$ & 0,0001 & 1,0 & $<\mathrm{LD}$ \\
Bário & $\mathrm{mg} \mathrm{Ba} \cdot \mathrm{L}^{-1}$ & 0,001 & 70,0 & 15,24 \\
Cádmio & $\mathrm{mg} \mathrm{Cd} \cdot \mathrm{L}^{-1}$ & 0,0006 & 0,5 & $<\mathrm{LD}$ \\
Chumbo & $\mathrm{mg} \mathrm{Pb} \cdot \mathrm{L}^{-1}$ & 0,01 & 1,00 & 0,10 \\
Cromo total & $\mathrm{mg} \mathrm{Cr} \cdot \mathrm{L}^{-1}$ & 0,005 & 5,0 & 0,027 \\
Fluoretos & $\mathrm{mg} \mathrm{F} \cdot \mathrm{L}^{-1}$ & 0,01 & 150,0 & 0,14 \\
Mercúrio & $\mathrm{mg} \mathrm{Hg} \cdot \mathrm{L}^{-1}$ & 0,0001 & 0,1 & $<\mathrm{LD}$ \\
Prata & $\mathrm{mg} \mathrm{Ag} \cdot \mathrm{L}^{-1}$ & 0,001 & 5,0 & 0,008 \\
Selênio & $\mathrm{mg} \mathrm{Se} \cdot \mathrm{L}^{-1}$ & 0,001 & 1,0 & $<\mathrm{LD}$ \\
pH do Lixiviado & - & N.A & 0 & 7,70 \\
\hline
\end{tabular}

Obs. Limite máximo no extrato - anexo normativo (F) - NBR 10004/2004.

Tabela 4.4 - Resultados do ensaio de solubilização do agregado reciclado de concreto.

\begin{tabular}{|c|c|c|c|c|}
\hline PARÂMETRO & UNIDADE & $\begin{array}{c}\text { LIMITE DE } \\
\text { DETECÇÃO (LD) }\end{array}$ & $\begin{array}{l}\text { LIMITE MÁXIMO } \\
\text { NO EXTRATO }\end{array}$ & ARC \\
\hline Alumínio & mg Al . $\mathrm{L}^{-1}$ & 0,01 & 0,2 & 3,62 \\
\hline Cádmio & $\mathrm{mg} \mathrm{Cd} \cdot \mathrm{L}^{-1}$ & 0,0006 & 0,005 & $<\mathrm{LD}$ \\
\hline Chumbo & $\mathrm{mg} \mathrm{Pb} \cdot \mathrm{L}^{-1}$ & 0,01 & 0,01 & $<L D$ \\
\hline Cianetos & $\operatorname{mg~CN} \cdot L^{-1}$ & 0,001 & 0,07 & $<L D$ \\
\hline Cloretos & $\mathrm{mg} \mathrm{Cl} \cdot \mathrm{L}^{-1}$ & 0,01 & 250 & 8,7 \\
\hline Cobre & $\mathrm{mg} \mathrm{Cu} \cdot \mathrm{L}^{-1}$ & 0,003 & 2,0 & 0,027 \\
\hline Cromo total & $\mathrm{mg} \mathrm{Cr} \cdot \mathrm{L}^{-1}$ & 0,005 & 0,05 & 0,041 \\
\hline Fenóis totais & $\mathrm{mg} \mathrm{C}_{6} \mathrm{H}_{5} \mathrm{OH} \cdot \mathrm{L}^{-1}$ & 0,001 & 0,01 & 0,024 \\
\hline Ferro total & $\mathrm{mg} \mathrm{Fe} \cdot \mathrm{L}^{-1}$ & 0,005 & 0,3 & 0,043 \\
\hline Fluoretos & $\mathrm{mg} \mathrm{F} \cdot \mathrm{L}^{-1}$ & 0,01 & 1,5 & 0,05 \\
\hline Manganês & $m g M n \cdot L^{-1}$ & 0,003 & 0,1 & 0,004 \\
\hline Nitratos & $\mathrm{mg} \mathrm{N} \cdot \mathrm{L}^{-1}$ & 0,01 & 10 & 2,39 \\
\hline Prata & $\mathrm{mg} \mathrm{Ag} \cdot \mathrm{L}^{-1}$ & 0,001 & 0,05 & $<\mathrm{LD}$ \\
\hline Sódio & $\mathrm{mg} \mathrm{Na} \cdot \mathrm{L}^{-1}$ & 0,1 & 200 & 17 \\
\hline Sulfatos & $\mathrm{mgSO}_{4}{ }^{2} \cdot \mathrm{L}^{-1}$ & 1 & 250 & 33 \\
\hline Surfactantes & mg LAS . $L^{-1}$ & 0,1 & 0,5 & $<\mathrm{LD}$ \\
\hline Zinco & $m g Z n \cdot L^{-1}$ & 0,02 & 5,0 & $<L D$ \\
\hline pH do Solubilizado & & 0 & Não se aplica & 11,47 \\
\hline
\end{tabular}

Obs. Limite máximo no extrato - anexo normativo (G) - NBR 10004/2004 
Analisando-se os resultados obtidos no ensaio de lixiviação expressos na Tabela 4.3, verifica-se que as concentrações dos elementos presentes no agregado reciclado de concreto satisfazem aos limites preconizados no anexo $\mathrm{F}$ da norma NBR 10004 (ABNT, 2004a). No entanto, observando-se os resultados do ensaio de solubilização apresentados na Tabela 4.4, nota-se que o agregado reciclado apresenta concentrações de alumínio e fenóis totais superiores aos limites propostos no anexo G da norma NBR 10004.

A partir desses resultados, o agregado reciclado de concreto pode ser classificado, de acordo com a norma NBR 10004, como sendo da Classe II-A, isto é, resíduo não perigoso e não inerte. Esse resultado contrasta com o esperado, pois os resíduos de construção e demolição são considerados, geralmente, como inertes. Entretanto, Fernandes (2004) relata que o agregado reciclado misto proveniente da Usina de Catumbi, Rio de Janeiro-RJ, apresentou também concentrações de alumínio e fenóis superiores às permitidas, sendo igualmente classificado como pertencente à Classe II-A. Ainda de acordo com este pesquisador, "tais resultados não inviabilizam o uso de agregados reciclados de RCD. No entanto, estes resultados indicam uma atenção especial ao seu emprego, por exemplo, cuidados a serem tomados com a drenagem de águas superficiais e subterrâneas" (pág. 92).

Ainda neste âmbito, observa-se que diversos materiais empregados na construção de camadas de pavimentos podem ser considerados como não inertes, tais como cimento, cal, emulsão asfáltica, etc. Salienta-se que até mesmo alguns solos tropicais são classificados, com base nos limites propostos na norma NBR 10004, como não inertes. A Tabela 4.5 apresenta um exemplo disso, no qual um 
solo oriundo do interior do Estado de São Paulo, coletado sob condições normais, sem contato conhecido com nenhuma forma de contaminação, apresenta concentrações de alguns elementos químicos acima dos valores prescritos por esta norma. Esse resultado foi obtido de Silva Júnior (2009), pesquisa em andamento do Departamento de Transportes da EESC/USP. Analisando-se essa tabela, é possível verificar que o solo apresenta concentrações de chumbo e fenóis totais acima do permitido. Outro exemplo de solo tropical que foi considerado como não inerte pode ser visto no trabalho de Klinsky (2008). O solo designado como "solo Jardim Maracanã" apresentou uma concentração de fenóis quatro vezes superior à máxima permitida na norma NBR 10004.

Tabela 4.5 - Resultados de solubilização acima dos prescritos por norma de um solo do interior paulista (SILVA JÚNIOR, 2009).

\begin{tabular}{ccccc}
\hline PARÂMETRO & UNIDADE & $\begin{array}{c}\text { LIMITE DE } \\
\text { DETECÇÃO (LD) }\end{array}$ & $\begin{array}{c}\text { LIMITE MÁXIMO } \\
\text { NO EXTRATO }\end{array}$ & SOLO \\
\hline Chumbo & $\mathrm{mg} \mathrm{Pb} \cdot \mathrm{L}^{-1}$ & 0,01 & 0,01 & 0,03 \\
Fenóis totais & $\mathrm{mg} \mathrm{C6H5OH} . \mathrm{L}^{-1}$ & 0,001 & 0,01 & 0,035 \\
\hline
\end{tabular}

Obs. Limite máximo no extrato - anexo normativo (G) - NBR 10004/2004.

Com base no exposto acima, partilha-se do mesmo ponto de vista relatado em Fernandes (2004), isto é, que até mesmo quando as classificações ambientais indicarem que os agregados reciclados de RCD não são inertes, estes não devem ser inviabilizados para o emprego em pavimentação.

\subsection{ENSAIOS DE COMPACTAÇÃO}

Os ensaios de compactação do agregado reciclado de concreto, sem adição de solo, foram realizados nas energias intermediária e modificada, do ensaio de Proctor. Na Figura 4.2, são ilustrados os resultados obtidos. 


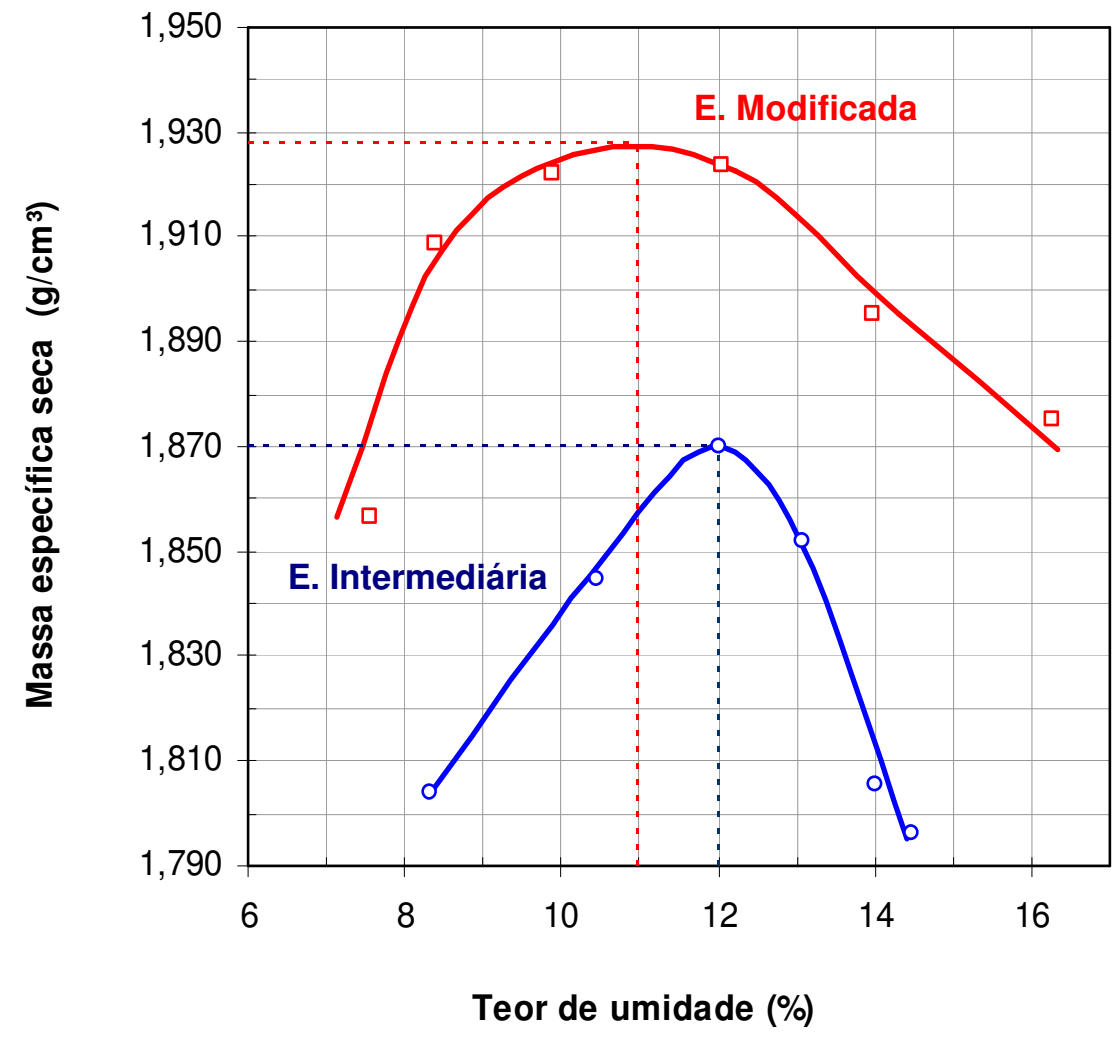

Figura 4.2 - Curvas de compactação do ARC para as energias intermediária e modificada.

Ao contrário do observado em alguns trabalhos relacionados a agregados reciclados de resíduos de construção e demolição, como por exemplo o de Motta (2005), na presente pesquisa as curvas de compactação do agregado reciclado apresentam o formato tradicional, isto é, formato típico de "sino", com pico bem delineado. Este fato deve ser destacado, pois de acordo com Leite (2007), a umidade ótima de agregados reciclados de RCD é geralmente muito difícil de ser determinada.

Ao observar a Figura 4.2, verifica-se que a energia de compactação influencia nos valores de massa específica seca máxima $\left(\rho_{\mathrm{dmax}}\right)$ e umidade ótima $\left(\omega_{\mathrm{o}}\right)$ do agregado reciclado de concreto. Conforme o esperado, a curva de compactação obtida para energia modificada apresenta uma $\rho_{d m a x}$ maior e uma $\omega_{\circ}$ menor em 
relação à curva determinada para energia intermediária. Foram obtidas massas específicas aparentes secas máximas de $1,928 \mathrm{~g} / \mathrm{cm}^{3}$ e $1,870 \mathrm{~g} / \mathrm{cm}^{3}$ e umidades ótimas de $11,0 \%$ e $12,0 \%$ paras energias modificada e intermediária, respectivamente.

Para fins de comparação, a Tabela 4.6 apresenta os resultados de compactação do agregado reciclado de concreto obtidos nesta pesquisa, confrontados com os encontrados na bibliografia consultada.

Tabela 4.6 - Umidade ótima e massa específica seca máxima dos ARC.

\begin{tabular}{ccccc}
\hline PROCEDÊNCIA & FONTE & $\begin{array}{c}\text { ENERGIA DE } \\
\text { COMPACTAÇÃO }\end{array}$ & $\begin{array}{c}\boldsymbol{\omega}_{\mathbf{o}} \\
\mathbf{( \% )}\end{array}$ & $\begin{array}{c}\boldsymbol{\rho}_{\mathbf{d}, \mathbf{M a x}} \\
\mathbf{( g / \mathbf { c m } ^ { 3 }}\end{array}$ \\
\cline { 2 - 6 } & Nataatmadja et al. (2001) & Modificada & 9,5 & 2,000 \\
China & Poon et al (2006) & - & 11,8 & 2,020 \\
Coréia & Park (2003) & Modificada & 9,0 & 2,210 \\
EUA & Blankenagel et al. (2006) & Modificada & 9,7 & 1,830 \\
EUA & Bennert et al. (2000) & Normal & 7,5 & 1,984 \\
Suécia & Arm (2001) & Modificada & 9,4 & 2,000 \\
\hline \multirow{2}{*}{ Brasil } & Fernandes (2004) & Intermediária & 15,2 & 1,820 \\
& & Modificada & 14,1 & 1,870 \\
\cline { 2 - 6 } & \multirow{2}{*}{ Esta Pesquisa } & Intermediária & 12,0 & 1,870 \\
& & Modificada & 11,0 & 1,928 \\
\hline
\end{tabular}

Observando-se a Tabela 4.6, constata-se que na maioria das pesquisas internacionais, a energia escolhida para compactação do agregado reciclado de concreto foi a modificada. Para essa energia, pode-se observar que os valores encontrados na revisão bibliográfica de umidade ótima e massa específica seca máxima variam de $9,0 \%$ a $14,1 \%$ e de $1,830 \mathrm{~g} / \mathrm{cm}^{3}$ a $2,210 \mathrm{~g} / \mathrm{cm}^{3}$, respectivamente. Além disso, ressalta-se que os resultados determinados nesta pesquisa de compactação do ARC empregando a energia modificada estão contidos nestes intervalos. 
Ainda na Tabela 4.6, comparando-se os resultados determinados nesta pesquisa com os relatados por Fernandes (2004), observa-se que as umidades ótimas determinadas para as energias intermediária e modificada da presente pesquisa foram menores em aproximadamente em $3 \%$, em termos absolutos, enquanto que as massas específicas secas máximas foram maiores em cerca de $0,050 \mathrm{~g} / \mathrm{cm}^{3}$. Quando se considera apenas a influência da energia de compactação sobre os resultados, verifica-se que o incremento de energia produziu os mesmo efeitos nas duas pesquisas. Isto é, em ambos os trabalhos, houve uma redução próxima de $1 \%$ na umidade ótima (em termos absolutos) e um aumento de cerca de $0,05 \mathrm{~g} / \mathrm{cm}^{3}$ na massa específica seca máxima.

No tocante à escolha de energia de compactação, a norma que trata da execução de camadas de pavimentos empregando agregados reciclados de resíduos de construção civil, a 15115 (ABNT, 2004e), recomenda no mínimo a energia intermediária para emprego na construção de bases e a maioria das pesquisas internacionais emprega a energia modificada. Para efeito de comparação, nos demais materiais estudados, optou-se pelo emprego da energia modificada.

A curva de compactação do solo é mostrada na Figura 4.3. Já a curva de compactação da mistura de agregado reciclado de concreto com o solo (ARC-solo) é ilustrada na Figura 4.4. Observa-se que para facilitar a avaliação da influência da adição de solo no agregado reciclado, a curva do ARC moldado na energia modificada foi repetida na Figura 4.4. 


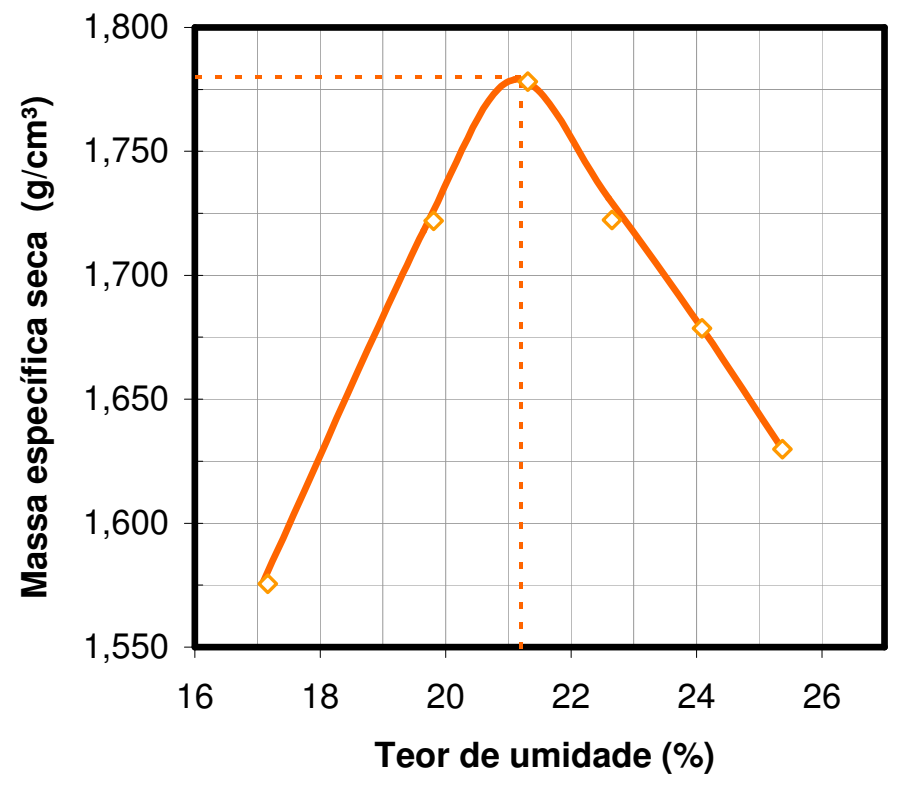

Figura 4.3 - Curva de compactação solo (energia modificada).

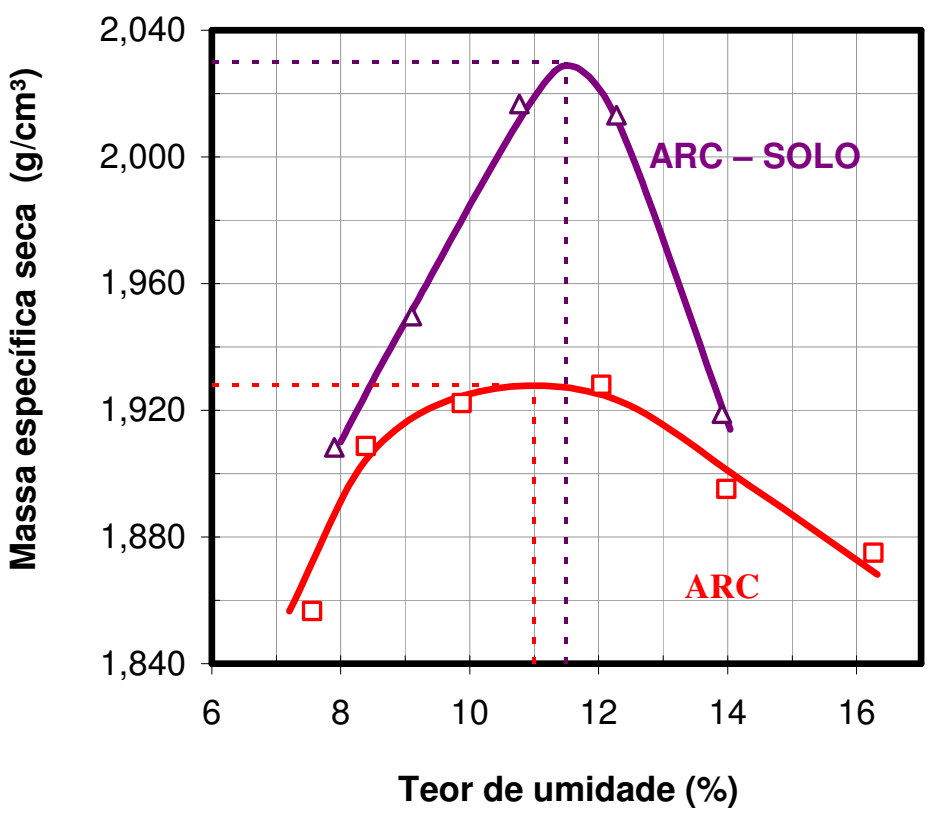

Figura 4.4 - Curvas de compactação do ARC-solo e do ARC (energia modificada).

Analisando-se a Figura 4.3, verifica-se que o solo compactado na energia modificada apresenta massa específica seca máxima de $1,780 \mathrm{~g} / \mathrm{cm}^{3}$ e umidade ótima de $21,2 \%$. Na Figura 4.4, observa-se que a mistura de agregados reciclados de concreto com solo apresenta maior massa específica seca máxima e umidade 
ótima do que o ARC in natura. Foram obtidas massas específicas aparentes secas máximas de 2,030 g/ $/ \mathrm{cm}^{3}$ e $1,928 \mathrm{~g} / \mathrm{cm}^{3}$ e umidades ótimas de $11,5 \%$ e $11,0 \%$ para o ARC-solo e ARC, respectivamente. Comparando-se os resultados apresentados na Figuras 4.3 e 4.4, constata-se que o solo apresenta massa específica bem inferior às determinadas para o agregado reciclado puro.

Finalmente, a curva de compactação obtida para o agregado natural é mostrada na Figura 4.5. Examinando-se essa curva de compactação, observa-se que a massa específica seca máxima do agregado natural é de $2,330 \mathrm{~g} / \mathrm{cm}^{3}$, enquanto sua umidade ótima é de $7,1 \%$. Confrontando-se esses resultados com os obtidos para o agregado reciclado de concreto, é possível observar que o ARC apresenta maior umidade ótima e menor massa específica seca máxima que o agregado natural. Esse fato pode ser explicado em função da maior absorção e menor densidade do agregado reciclado de concreto em relação ao agregado natural, conforme relatado na análise das características físicas dos agregados, Tópico 4.2.

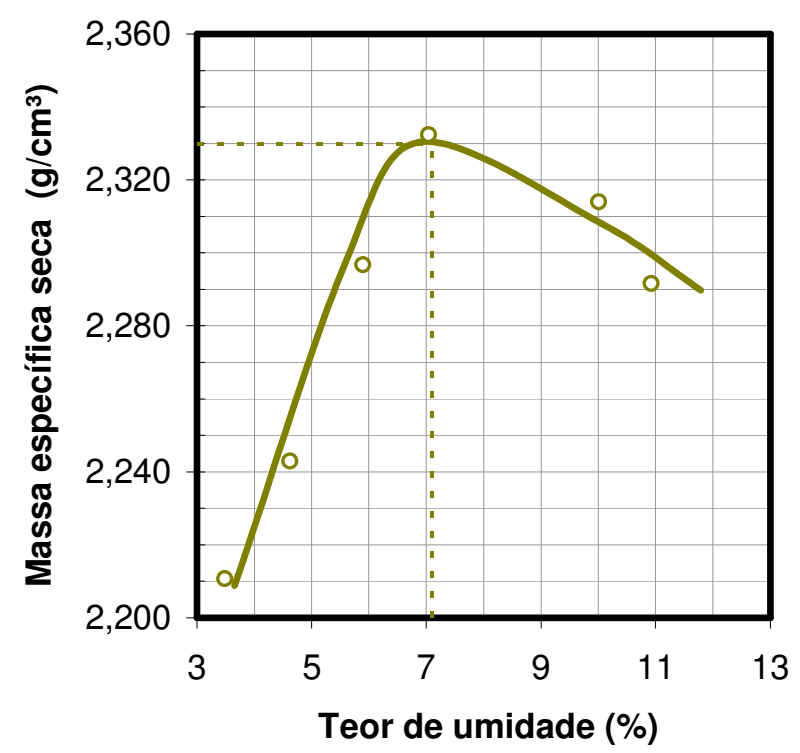

Figura 4.5 - Curva de compactação do agregado natural (energia modificada). 


\subsubsection{Desvio de umidade versus grau de compactação}

Complementarmente, neste tópico, os resultados de compactação são avaliados de forma distinta da usual. Analisa-se o desvio de umidade de compactação versus o grau de compactação (GC). O desvio de umidade é determinado pela diferença entre a umidade do ponto de compactação e a umidade ótima do material, enquanto o grau de compactação é dado pela relação entre a massa específica seca do ponto pela massa específica seca máxima do material. Destaca-se que este procedimento nada mais é do que uma normalização das curvas de compactação que facilita a verificação da influência da umidade sobre a compactação do material. Com base nisto, por exemplo, é possível determinar para cada material qual é a variação de umidade aceitável para se obter certo grau de compactação. No caso de bases de pavimentos, observa-se que o desvio de umidade aceito em campo é em torno de $2 \%$.

A Figura 4.6 apresenta a variação do desvio de umidade versus o grau de compactação para o agregado reciclado de concreto compactado para as duas energias pesquisadas. A Figura 4.7, mostra a mesma avaliação para a mistura ARCsolo e para o solo, enquanto a Figura 4.8 ilustra essa análise para o agregado natural. Observa-se que para facilitar à comparação, optou-se por repetir a curva obtida para o agregado reciclado de concreto compactado na energia modificada nas Figuras 4.7 e 4.8. 


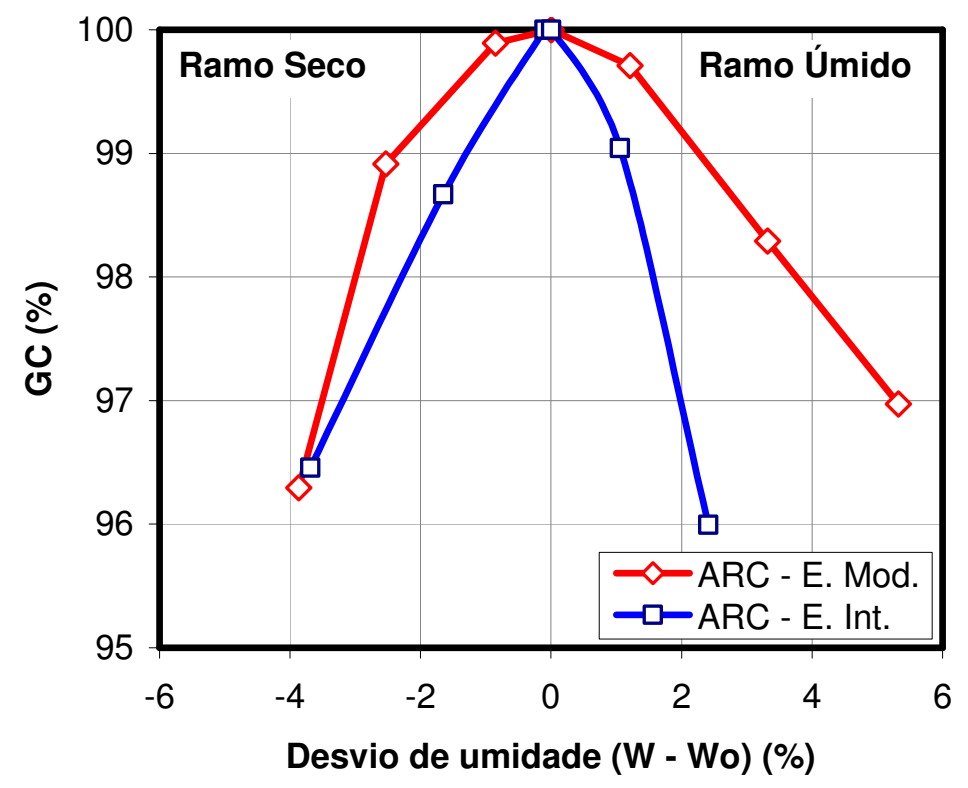

Figura 4.6 - Grau de compactação versus desvio de umidade do ARC.

Analisando-se a Figura 4.6, é possível verificar que o agregado reciclado de concreto compactado na energia modificada é menos sensível ao desvio de umidade de compactação do que o mesmo material compactado na energia intermediária. No ramo seco, para um desvio de umidade de $2 \%$, os graus de compactação do ARC compactado nas energias modificada e intermediária foram $99,2 \%$ e $98,3 \%$, respectivamente. No ramo úmido, para o mesmo desvio de umidade, os graus de compactação do ARC, compactado nas energias modificada e intermediária foram 99,2\% e 97,0\%, respectivamente. 


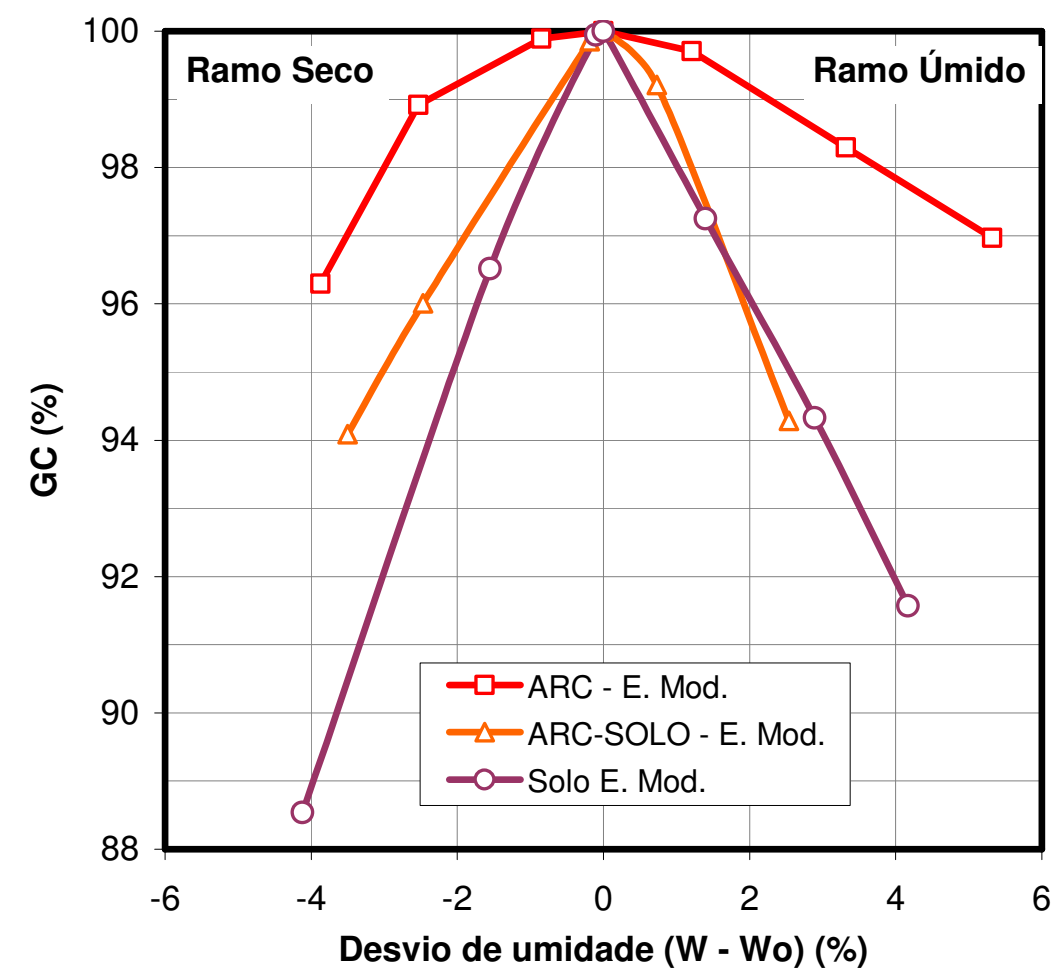

Figura 4.7 - Grau de compactação versus desvio de umidade do ARC e do ARC-solo.

Com base na Figura 4.7, é possível verificar que o agregado reciclado de concreto compactado na energia modificada é menos sensível, tanto no ramo seco quanto no ramo úmido, ao desvio de umidade de compactação do que a mistura ARC-solo e do que o solo. No ramo seco, para um desvio de umidade de $2 \%$, os graus de compactação do ARC, da mistura ARC-solo e do solo são $99,2 \%, 97 \%$ e 95,2\%, respectivamente. Já no ramo úmido, para o mesmo desvio de umidade, os graus de compactação do ARC, da mistura ARC-solo e do solo são de $99,2 \%, 96 \%$ e $96,1 \%$, respectivamente. Observa-se ainda, que a diferença de grau de compactação do solo em relação ao agregado reciclado de concreto é mais expressiva quando se aumenta o desvio de umidade. No ramo seco para o desvio de umidade de $4 \%$, o GC do ARC é de $96 \%$, enquanto o do solo é de apenas $88 \%$. No ramo úmido, para o mesmo desvio de umidade, o GC do ARC é de $98 \%$ e o do 
solo é $91 \%$. Portanto, quando se considera um desvio de umidade de $4 \%$ acima ou abaixo da umidade ótima, verifica-se que o agregado reciclado de concreto apresenta um grau de compactação em torno de 7\%, em termos absolutos, maior do que o verificado no solo.

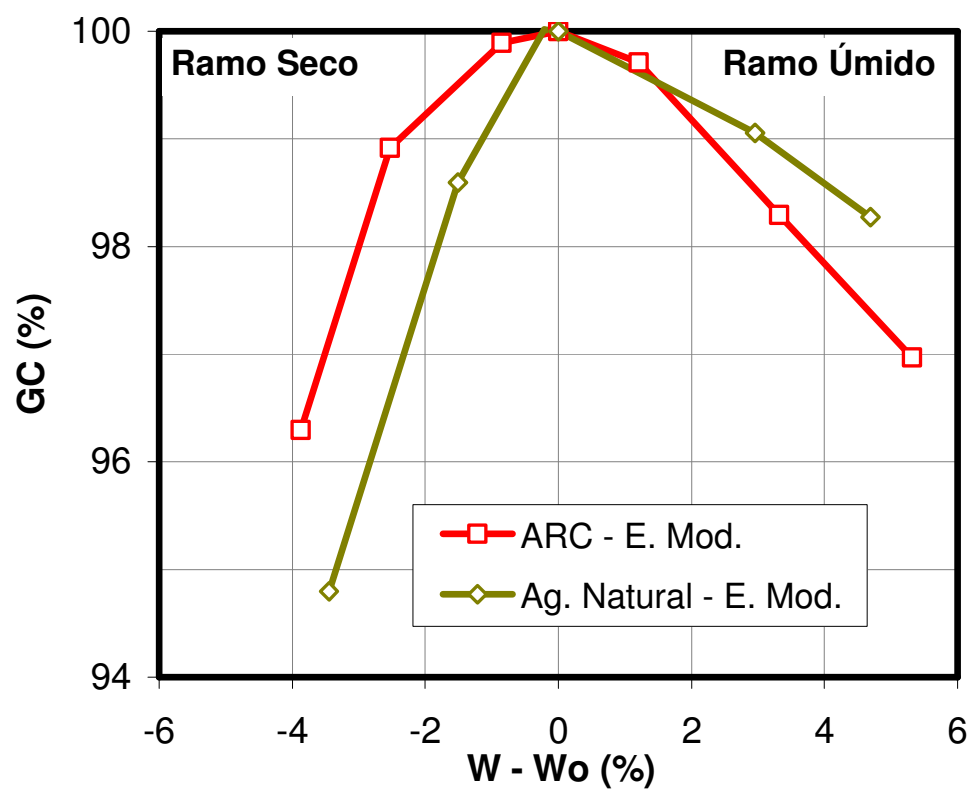

Figura 4.8 - Grau de compactação versus desvio de umidade do ARC e do agregado natural.

Observando-se a Figura 4.8, verifica-se que o agregado reciclado de concreto é menos sensível à umidade de compactação do que o agregado natural no ramo seco e mais sensível no ramo úmido, ambos materiais compactados na energia modificada. No ramo seco, para o desvio de umidade de $2 \%$, o grau de compactação do ARC foi de $99,2 \%$, enquanto o do agregado natural foi de $97,7 \%$. Já no ramo seco, para o mesmo desvio de umidade, o GC do $A R C$ foi de aproximadamente $99,2 \%$, enquanto o do agregado natural foi de $99,4 \%$. 


\subsubsection{Resumo dos resultados dos ensaios de compactação}

A Tabela 4.7 apresenta um resumo dos resultados determinados nos ensaios de compactação dos materiais examinados nesta pesquisa.

Tabela 4.7 - Quadro resumo dos resultados dos ensaios de compactação.

\begin{tabular}{cccc}
\hline MATERIAL & ENERGIA DE COMPACTAÇÃO & $\boldsymbol{\omega}_{\mathbf{o}}(\%)$ & $\boldsymbol{\rho}_{\mathbf{d}, \mathbf{M a x}}\left(\mathbf{g} / \mathbf{c m}^{\mathbf{3}}\right)$ \\
\hline ARC & Intermediária & 12,0 & 1,870 \\
ARC-solo & Modificada & 11,0 & 1,928 \\
Solo & Modificada & 11,5 & 2,030 \\
Agregado natural & Modificada & 21,2 & 1,780 \\
\hline
\end{tabular}

\subsection{ANÁLISE DA DEGRADAÇÃO}

A avaliação da degradação do agregado reciclado de concreto foi feita com base na análise da distribuição granulométrica de uma amostra antes e depois de sua compactação na energia modificada. Essa amostra foi compactada na condição de massa específica seca máxima e umidade ótima. Os resultados desta avaliação são mostrados na Tabela 4.8 e na Figura 4.9.

Tabela 4.8 - Degradação do agregado reciclado de concreto.

\begin{tabular}{cccccc}
\hline \multirow{2}{*}{$\begin{array}{c}\text { PENEIRAS } \\
(\mathbf{m m})\end{array}$} & \multicolumn{5}{c}{ PORCENTAGEM PASSANTE (\%) } \\
\cline { 2 - 6 } & $\begin{array}{c}\text { FAIXA C } \\
\text { INFERIOR }\end{array}$ & $\begin{array}{c}\text { FAIXA C } \\
\text { SUPERIOR }\end{array}$ & $\begin{array}{c}\text { ANTES DA } \\
\text { COMPACTAÇÃO }\end{array}$ & $\begin{array}{c}\text { DEPOIS DA } \\
\text { COMPACTAÇÃO }\end{array}$ & DIFERENÇA \\
\hline 25 & 100 & 100 & 100 & 100 & 0 \\
9,52 & 50 & 85 & 75 & 77 & 2 \\
4,76 & 35 & 65 & 52 & 55 & 3 \\
2 & 25 & 50 & 41 & 44 & 3 \\
0,42 & 15 & 30 & 18 & 24 & 5 \\
0,074 & 5 & 15 & 2 & 3 & 1 \\
\hline
\end{tabular}




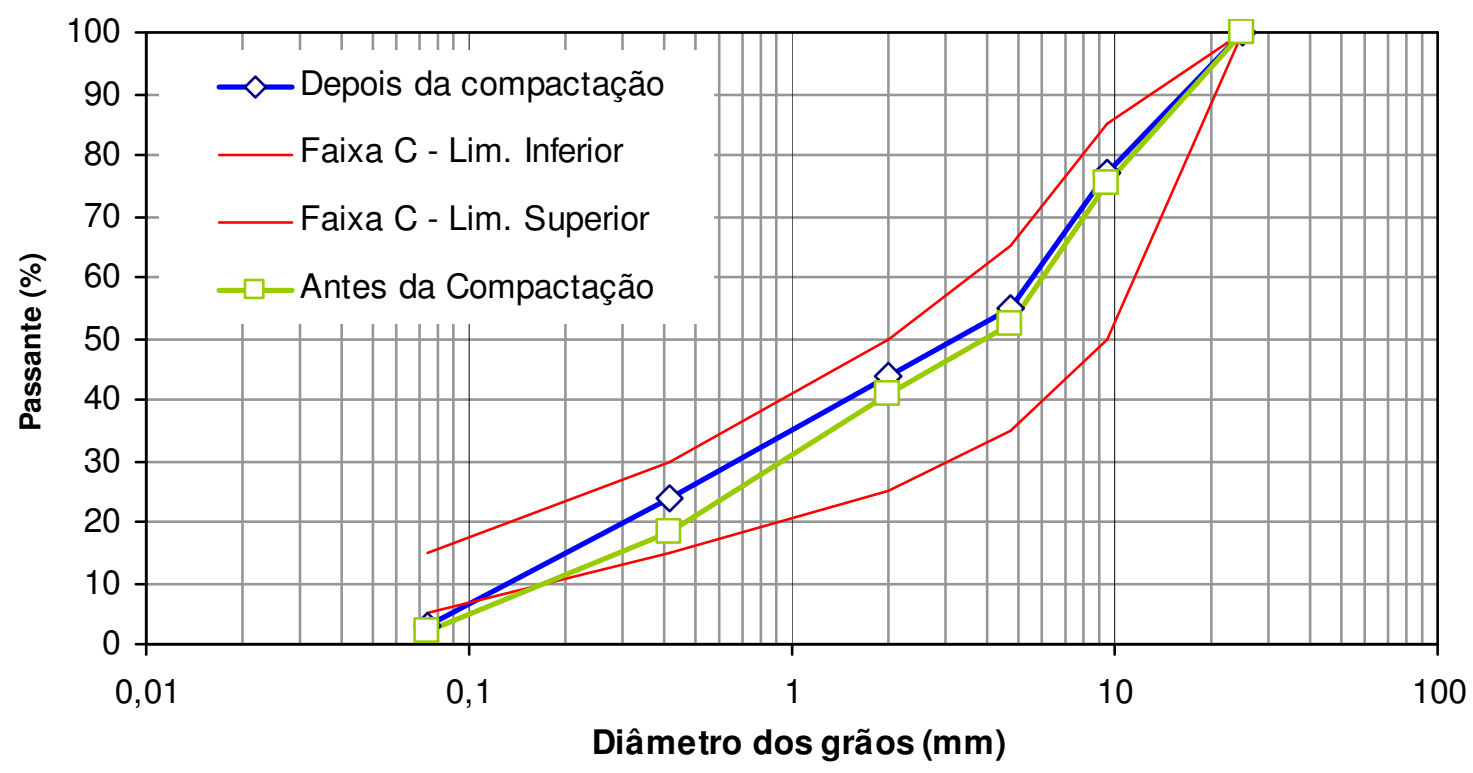

Figura 4.9 - Degradação do agregado reciclado de concreto.

Analisando-se os valores apresentados na Tabela 4.8 e ilustrados na Figura 4.9, verifica-se que a degradação do agregado reciclado de concreto foi pouco significativa. A diferença média de percentual passante por peneira foi de apenas $2,8 \%$, sendo a maior diferença encontrada na peneira de número $40(0,042 \mathrm{~mm})$, aproximadamente $5 \%$.

O agregado reciclado de concreto apresentou quebras menos expressivas durante o processo de compactação do que o relatado em pesquisas envolvendo agregados reciclados mistos, como por exemplo, em Motta (2005) e Leite (2007). De acordo com Motta (2005), "de maneira geral, a compactação promoveu notáveis mudanças na granulometria do agregado reciclado" (pág. 69). Acredita-se que essa diferença de resistência à quebra durante a compactação se deva a natureza dos seus materiais constituintes. O ARC é composto predominantemente por resíduos 
de concreto e materiais pétreos, sendo a presença de materiais cerâmicos pouca expressiva, ao contrário das pesquisas supracitadas.

\section{6. ÍNDICE DE SUPORTE CALIFÓRNIA}

Os valores de CBR e de expansão são parâmetros requeridos pela norma 15115 (ABNT, 2004e) para o emprego de agregados reciclados em camadas de pavimentos, sendo seus limites mostrados na Tabela 4.9.

Tabela 4.9 - Limites de CBR e expansão preconizados pela norma NBR 15115.

\begin{tabular}{cccc}
\hline CAMADA & ENERGIA & CBR (\%) & EXPANSÃO (\%) \\
\hline Reforço de Subleito & Normal & $\geq 12$ & $\leq 1,0$ \\
Sub-base & Intermediária & $\geq 20$ & $\leq 1,0$ \\
Base & Intermediária & $\geq 60$ & $\leq 0,5$ \\
\hline
\end{tabular}

A Figura 4.10 apresenta a variação do CBR em função da umidade para o agregado reciclado de concreto e para o agregado natural, compactados na energia modificada. Esses resultados foram obtidos utilizando-se os mesmos corpos-deprova empregados no ensaio de compactação.

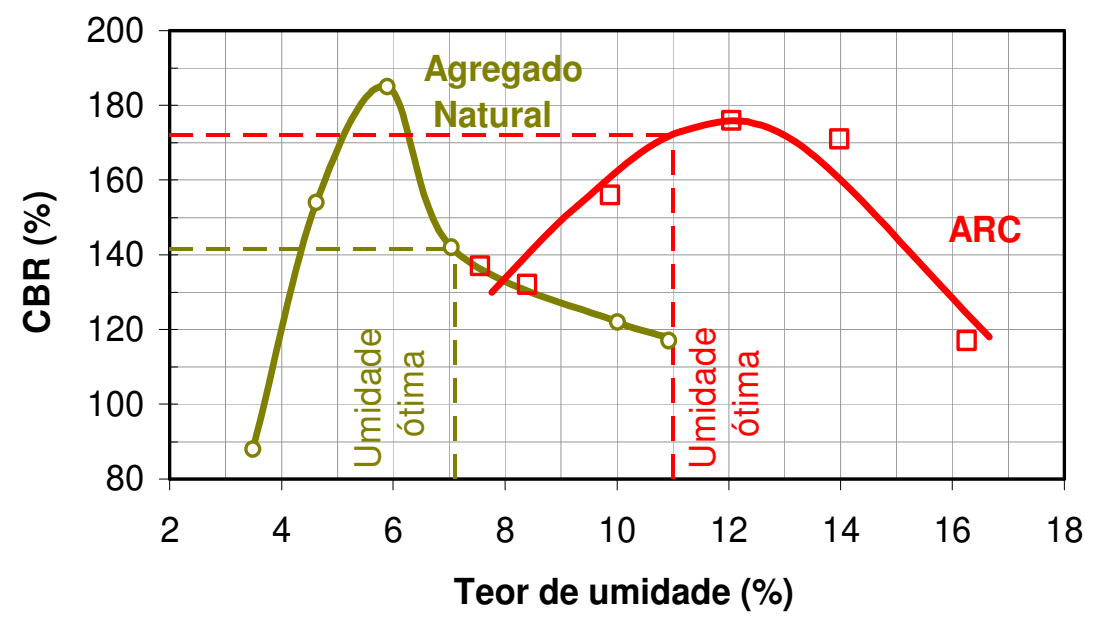

Figura 4.10 - Variação do CBR do ARC e do agregado natural em função do teor de umidade. 
Analisando-se a Figura 4.10, observa-se que tanto o agregado reciclado de concreto quanto o natural apresentam altos valores de CBR, acima de $80 \%$, para todos os teores de umidade testados. Os valores mínimos de CBR para o ARC e para o agregado natural são de $117 \%$ e $88 \%$, respectivamente. No tocante à influência da umidade na capacidade de suporte dos agregados, pode-se observar que o agregado reciclado de concreto é menos sensível à umidade de compactação do que o natural, isto é, mesmo tendo uma variação maior de umidade de compactação, sua capacidade de suporte se altera menos.

Ainda com base na Figura 4.10, verifica-se que o CBR do ARC na umidade ótima é de $172 \%$, enquanto o do agregado natural é de $142 \%$. Verifica-se também que o pico de CBR do ARC é de $176 \%$, semelhante ao observado no agregado natural que é de $185 \%$. No tocante ao teor de umidade no qual ocorre o CBR máximo do agregado reciclado de concreto, observa-se que o pico sucede para o teor de umidade de $12 \%$, isto é, ocorre no ramo úmido, uma vez que a umidade ótima é $11 \%$. Esse resultado não era esperado, geralmente verifica-se que o CBR máximo acontece no ramo seco, como o observado no agregado natural, neste material o pico de CBR é obtido para o teor de umidade $5,9 \%$, enquanto sua umidade ótima é de $7,1 \%$.

Objetivando-se maior confiabilidade dos resultados, em função da grande variabilidade do ensaio de CBR, no qual variações de cerca de $10 \%$ são consideradas como normais, e pelo fato da curva de CBR simultâneo ser realizada sem a confecção de réplicas de corpos-de-prova, foram realizados três ensaios de CBR na condição de umidade ótima e massa específica seca máxima para o 
agregado reciclado de concreto. Os resultados destes ensaios são apresentados na Tabela 4.10.

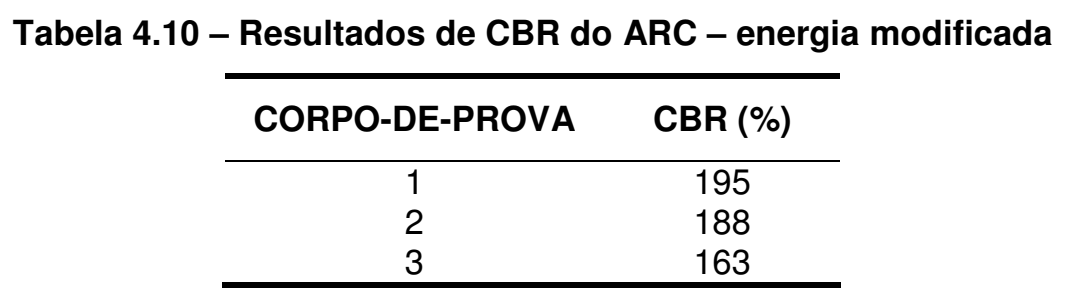

Analisando-se a Tabela 4.10, verifica-se que o CBR médio na umidade ótima é de $182 \%$, isto é, um pouco maior do que o valor de pico observado na Figura 4.10, que é de aproximadamente $176 \%$. Destaca-se que essa diferença está dentro da variabilidade do ensaio. Observa-se ainda que o valor de CBR na umidade ótima obtido nesta pesquisa está de acordo com os valores encontrados nas referências bibliográficas consultadas. O relatório "The Development of a Performance Specification for Granular Base and Subbase Material', publicado pela a FHWA em 2005, relata que o ARC, moldado na energia modificada, apresentou um CBR de 205\%. Segundo FHWA (1997), o CBR típico do ARC varia entre 94\% a 148\%. Já de acordo com Saeed et al (2007), este parâmetro varia entre de 94\% a 184\%.

Em relação à expansibilidade, medida durante os quatro dias imersos em água do ensaio, tanto agregado reciclado de concreto quanto o agregado natural apresentaram expansão nula. 


\subsubsection{Análise da Influência da Energia de Compactação no CBR do ARC}

Conforme mencionado anteriormente, a norma para o emprego de agregados reciclados de resíduos de construção em camadas de base, NBR 15115 (ABNT, 2004e) recomenda a utilização da energia de compactação intermediária, no mínimo. Porém, a maioria das pesquisas internacionais emprega a energia modificada. Dessa forma, para efeito de comparação foram realizados ensaios na umidade ótima também na energia intermediária, cujos resultados são apresentados na Tabela 4.11.

Tabela 4.11 - Resultados de CBR do ARC - energia intermediária

\begin{tabular}{cc}
\hline CORPO-DE-PROVA & CBR (\%) \\
\hline 1 & 120 \\
2 & 127 \\
3 & 129 \\
\hline
\end{tabular}

Analisando-se a Tabela 4.11, observa-se que o CBR médio do ARC moldado na energia intermediaria foi de $125 \%$. Esse valor é cerca de duas vezes maior do que o mínimo exigido pela norma NBR 15115 (ABNT, 2004e) para o emprego de agregado reciclado em camadas de base, e quando se considera a utilização em camadas de sub-base, esse valor é seis vezes maior.

Comparando-se as duas energias empregadas, verifica-se que a utilização da energia modificada acarretou um incremento de capacidade de suporte do agregado reciclado de concreto de $51 \%$, em termos absolutos. Isto é, a energia de compactação influenciou significativamente no índice de Suporte do agregado reciclado de concreto. 
Em relação à expansibilidade, o agregado reciclado moldado na energia intermediária, assim como o moldado na energia modificada, apresentou expansibilidade nula.

\subsubsection{Análise da Influência da Adição de Solo nos Valores de CBR}

A Tabela 4.12 mostra os valores de CBR obtidos para a mistura ARC-solo e para o solo. Conforme mencionado anteriormente, tanto a mistura ARC-solo quanto o solo foram compactados na energia modificada.

Tabela 4.12 - Resultados de CBR e expansão obtidos para o ARC-solo e para o solo.

\begin{tabular}{ccccc}
\hline \multirow{2}{*}{$\begin{array}{c}\text { CORPO-DE- } \\
\text { PROVA }\end{array}$} & \multicolumn{2}{c}{ CBR (\%) } & \multicolumn{2}{c}{ EXPANSÃO (\%) } \\
\cline { 2 - 5 } & ARC-SOLO & SOLO & ARC-SOLO & SOLO \\
\hline 1 & 173 & 54 & 0,0 & 0,25 \\
2 & 168 & 30 & 0,0 & 0,26 \\
3 & 152 & 38 & 0,0 & 0,37 \\
\hline
\end{tabular}

Analisando-se a Tabela 4.12, observa-se que ARC-solo apresenta um CBR médio de $164 \%$, ou seja, um valor ligeiramente inferior ao alcançado pelo agregado reciclado de concreto in natura, compactado na mesma energia (182\%). Já para o solo foi obtido um CBR médio de $41 \%$, valor bem inferior aos obtidos pelo agregado reciclado de concreto in natura e pelo $A R C$-solo. No tocante à expansão, tanto a mistura ARC-solo quanto o solo apresentaram valores inferiores a $0,5 \%$. 


\subsection{COMPORTAMENTO MECÂNICO}

Neste tópico, será apresentado e discutido o comportamento mecânico dos materiais empregados a partir da análise dos resultados dos ensaios de compressão simples, compressão diametral e triaxial cíclico.

\subsubsection{Ensaio de Compressão Simples}

\subsubsection{Considerações iniciais}

Conforme apresentado no Capítulo 3 - Materiais e Métodos, os ensaios de compressão simples foram executados em uma prensa instrumentada de maneira a fornecer a curva "tensão versus deformação", possibilitando assim, a determinação das resistências à compressão simples (tensão de ruptura) e dos módulos tangentes dos materiais pesquisados. A Figura 4.11 apresenta dois exemplos típicos de curvas "tensão versus deformação", determinadas para o agregado reciclado de concreto e para o solo.

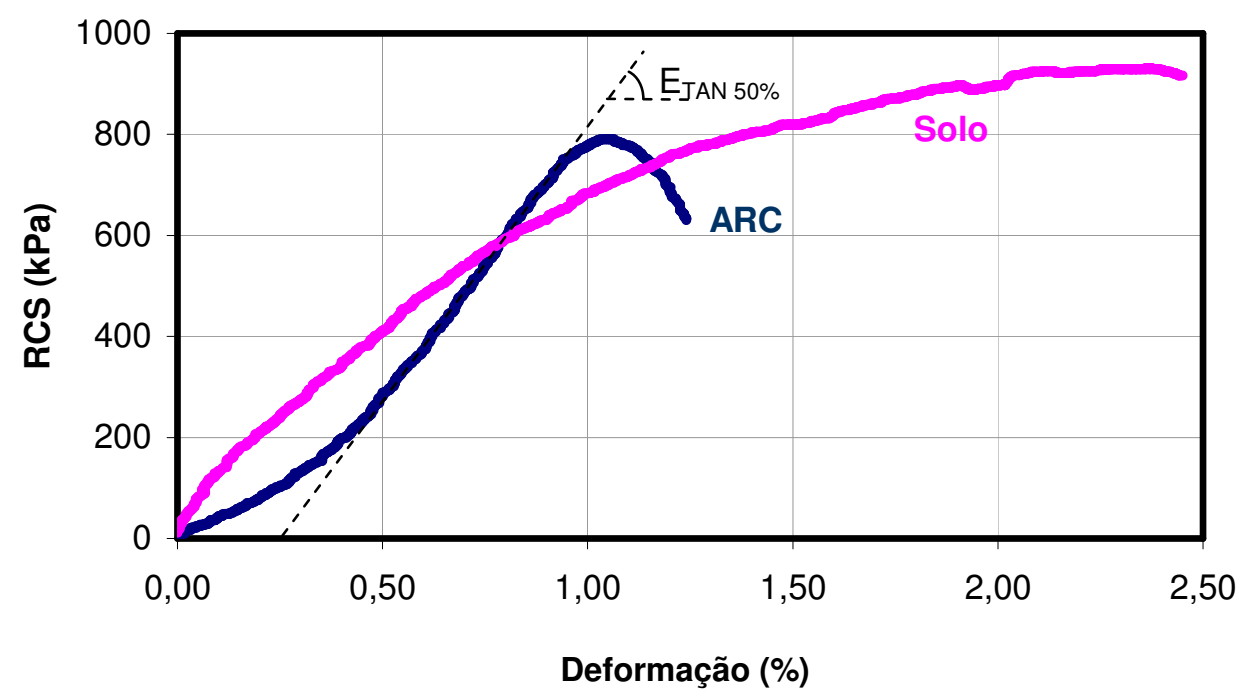

Figura 4.11 - Exemplos de curva tensão-deformação obtida de RCS do ARC e do solo. 
Analisando-se essa Figura 4.11, verifica-se que a curva determinada para o agregado reciclado de concreto, ao contrário do verificado para o solo, não apresenta um formato comum à maioria dos materiais geotécnicos, sendo que ambos os materiais foram ensaiados na mesma prensa. No trecho inicial, a curva do ARC apresenta uma concavidade para baixo diferentemente do observado na curva do solo. Uma hipótese que pode ser levantada para explicar esse fato seria a existência de fissuras presentes nos corpos-de-prova do agregado reciclado de concreto que viriam a ser fechadas durante o desenvolvimento do primeiro estágio da curva. A partir de sua consolidação, o ARC passaria a apresentar um comportamento típico de material geotécnico. Essa hipótese é decorrente da constatação visual da ocorrência de fissuras ao final da compactação e desmoldagem dos corpos-de-prova de agregados reciclados de concreto, o que não ocorreu para os corpos-de-prova de solo, conforme ilustra a Figura 4.12. Assim, para estudo da rigidez dos materiais, optou-se por não analisar o módulo tangente inicial, e sim, o módulo tangente a $50 \%$ da tensão de ruptura $\left(\mathrm{E}_{\mathrm{TAN} 50 \%}\right)$, conforme ilustrado na Figura 4.11.

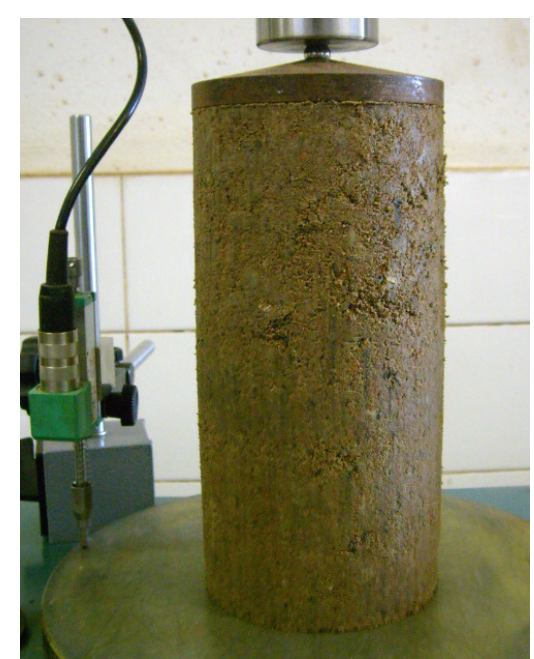

(a) Agregado reciclado de concreto

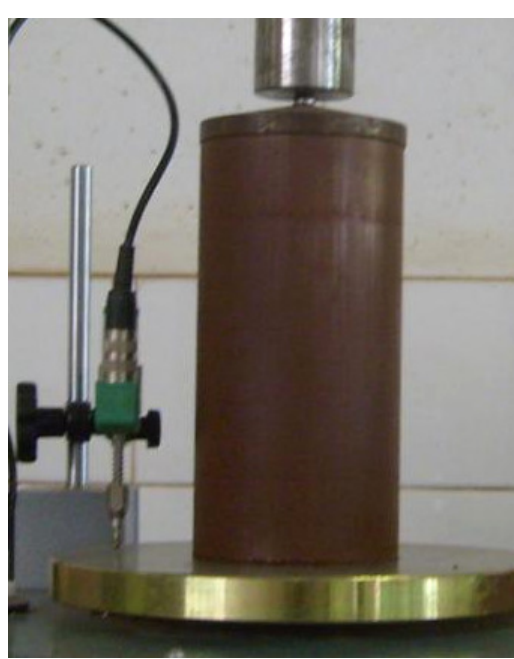

(b) Solo

Figura 4.12 - Aspectos de corpos-de-prova do ARC e do solo. 


\subsubsection{Resistência e rigidez imediata dos materiais}

A Tabela 4.13 apresenta os valores de resistência à compressão simples e módulo tangente a $50 \%$ da tensão de ruptura do agregado reciclado de concreto, compactado nas energias intermediária e modificada, e dos demais materiais compactados apenas na energia modificada. Observa-se que não foram realizados ensaios de compressão simples no agregado natural em virtude da dificuldade de moldagem dos mesmos.

Tabela 4.13 - Resistência e rigidez imediata dos materiais pesquisados.

\begin{tabular}{cccc}
\hline MATERIAL & $\begin{array}{c}\text { ENERGIA DE } \\
\text { COMPACTAÇÃO }\end{array}$ & RCS (kPa) & $\begin{array}{c}\mathbf{E}_{\text {TAN, 50\% }} \\
\text { (MPa) }\end{array}$ \\
\hline ARC & Intermediária & 201 & 62 \\
ARC & Modificada & 336 & 80 \\
ARC-solo & Modificada & 331 & 120 \\
Solo & Modificada & 948 & 630 \\
\hline
\end{tabular}

Com base na Tabela 4.13, ilustram-se nas Figuras 4.13 e 4.14 as resistências à compressão simples e os módulos tangentes dos materiais moldados na energia modificada, respectivamente.

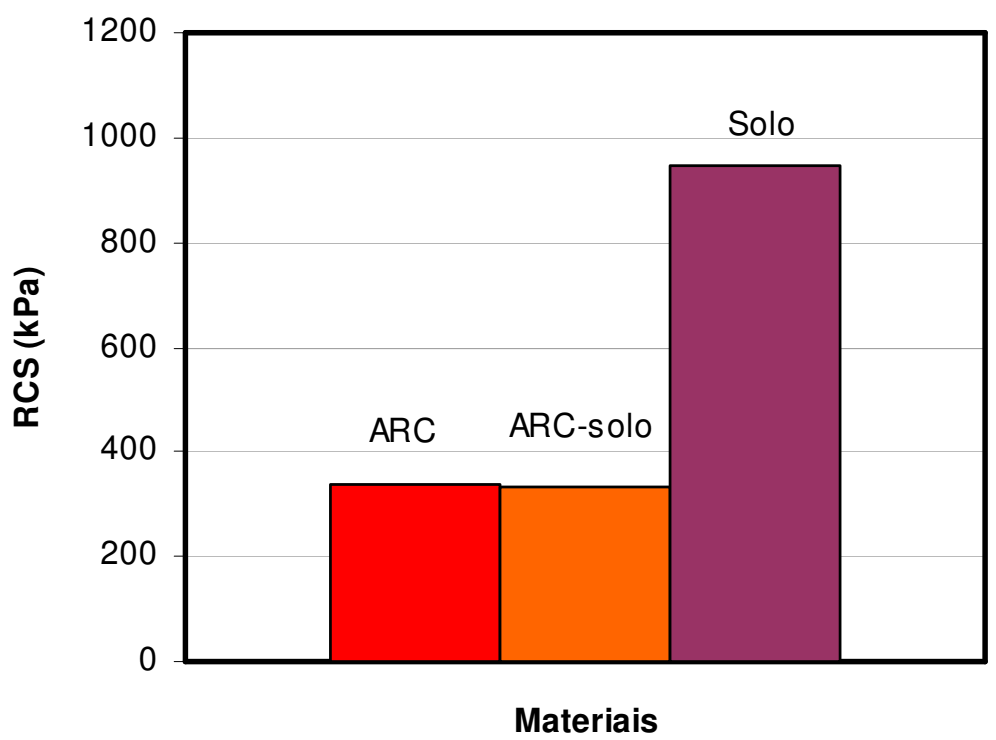

Figura 4.13 - RCS dos materiais compactados na energia modificada. 


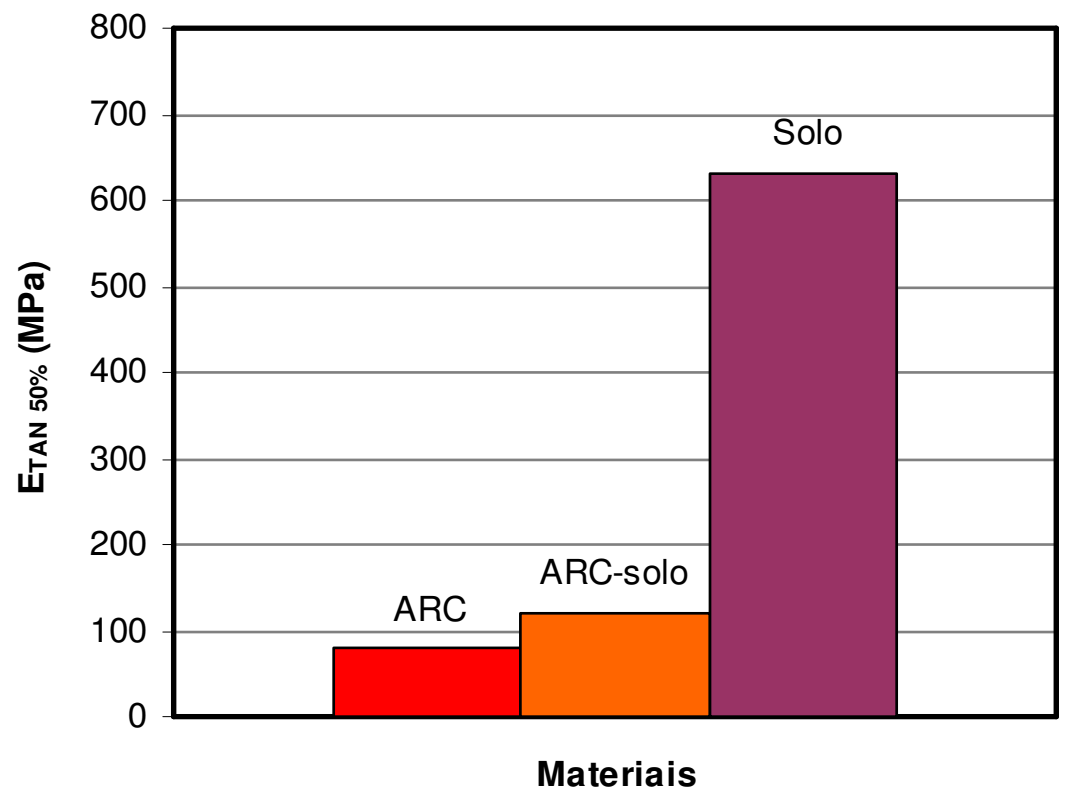

Figura 4.14 - Módulo tangente dos materiais compactados na energia modificada.

Analisando-se a Figura 4.13, verifica-se que a resistência à compressão simples do agregado reciclado de concreto é semelhante à observada na mistura de ARC-solo, isto é, a adição de $25 \%$ de solo ao agregado reciclado de concreto não teve influência sobre este parâmetro. No entanto, quando se examina a Figura 4.14, constata-se que a mistura $\mathrm{ARC}$-solo apresenta uma rigidez $50 \%$ maior do que a determinada para o agregado reciclado de concreto puro.

Observando-se as Figura 4.13 e 4.14, nota-se que o solo apresenta resistência e rigidez bem superiores às observadas para o agregado reciclado de concreto. A resistência à compressão simples do solo é cerca três vezes maior do que a do $A R C$, enquanto a rigidez é aproximadamente oito vezes superior. Esse resultado já era esperado, uma vez que a resistência e rigidez de solos argilosos lateríticos, avaliadas através do ensaio de compressão simples, são geralmente muito superiores às determinadas em materiais com graduação mais grossa. 
No tocante à influência da energia de compactação, analisando-se os valores apresentados na Tabela 4.13, constata-se o que incremento de energia de compactação produz aumentos na resistência e na rigidez do agregado reciclado de concreto de $67 \%$ e $29 \%$, respectivamente.

\subsubsection{Avaliação da resistência e rigidez do ARC ao longo do tempo}

A avaliação da compressão simples ao longo do tempo foi realizada para o agregado reciclado de concreto, compactado nas energias intermediária e modificada, para os períodos de 0, 3, 7, 28 e 90 dias de cura em câmara úmida.

A Tabela 4.14 apresenta os resultados de resistência à compressão simples do agregado reciclado de concreto para ambas energias empregadas. Esses resultados também são ilustrados na Figura 4.15.

Tabela 4.14 - Resultados de compressão simples do agregado reciclado de concreto

\begin{tabular}{ccccc}
\hline \multirow{2}{*}{$\begin{array}{c}\text { TEMPO } \\
\text { (dias) }\end{array}$} & \multicolumn{2}{c}{ RCS (kPa) } & \multicolumn{2}{c}{$E_{\text {TAN 50\% }}$ (MPa) } \\
\cline { 2 - 5 } & ENERGIA MOD. & ENERGIA INTER. & ENERGIA MOD. & ENERGIA INTER. \\
\hline 0 & 336 & 201 & 80 & 62 \\
3 & 473 & 256 & 88 & 81 \\
7 & 611 & 421 & 108 & 96 \\
28 & 787 & 673 & 133 & 119 \\
90 & 998 & 1023 & 180 & 166 \\
\hline
\end{tabular}




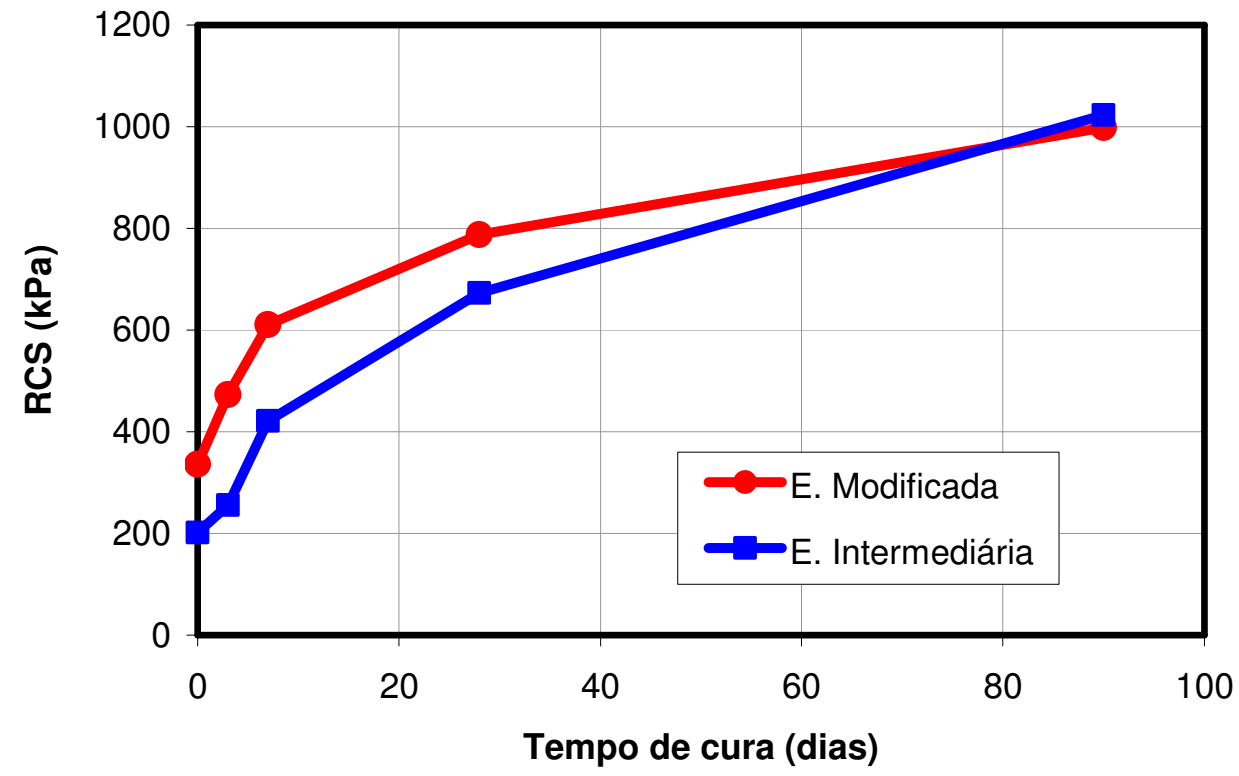

Figura 4.15 - Variação da RCS do agregado reciclado de concreto ao longo do tempo.

Analisando-se os resultados apresentados na Tabela 4.14 e ilustrados na Figura 4.15, verifica-se que há um aumento ao longo do tempo de cura da resistência à compressão simples do agregado reciclado de concreto para ambas energias pesquisadas. Para a energia modificada, avaliando-se comparativamente à resistência imediata ( 0 dia), constata-se que a resistência aos 7 dias de cura praticamente dobra e aos 90 dias, quase triplica. Os resultados são ainda mais expressivos quando se faz a mesma comparação para a energia intermediária, observa-se que a resistência aos 7 dias aproximadamente dobra, aos 28 dias, triplica e aos 90 dias, quintuplica.

Comparando-se as duas energias, verifica-se que a resistência à compressão simples do agregado reciclado de concreto moldado na energia modifica é superior a do compactado na energia intermediária até o período de 28 dias de cura em câmara úmida. A resistência imediata do agregado reciclado moldado na energia 
modificada foi aproximadamente $67 \%$ maior do que a do compactado na energia intermediária. Já aos 3, 7 e 28 dias de cura, as resistências do ARC compactado na energia modificada foram maiores do que as do moldado na intermediária em aproximadamente $85 \%, 45 \%$ e $17 \%$, respectivamente. Já aos 90 dias, a resistência do ARC compactado na energia intermediária foi superior a do moldado na energia modificada, embora, essa diferença, aproximadamente $2,5 \%$, possa ser atribuída à variabilidade do ensaio.

Observa-se que a influência da energia de compactação sobre os resultados de resistência à compressão simples com o transcorrer do tempo de cura diminuiu até o ponto em que aos 90 dias não houve mais diferença de resistência expressiva para as energias pesquisadas. Para os períodos de cura iniciais, acredita-se que a maior resistência alcançada quando empregada a energia modificada se deveu à maior densidade do material, e conseqüentemente ao maior número de contatos grãos a graus, mobilizando, assim, um maior atrito interno. Com o passar do tempo de cura, esse efeito foi encoberto pela hidratação das partículas de cimento presentes no agregado reciclado. Portanto, o efeito da coesão do material passou a preponderar sobre o efeito do atrito interno, obtido na compactação do material. Tal fenômeno é freqüentemente observado em misturas de solo-cimento, nas quais se emprega, geralmente, a energia normal, pois é sabido que o incremento de energia de compactação não produz melhoria expressiva do comportamento mecânico do material ao longo do tempo.

Uma hipótese que poderia ser levantada para explicar o fato que as taxas de incremento de resistência ao longo do tempo foram maiores para o ARC 
compactado na energia intermediária do que para o mesmo compactado na modificada, seria a maior umidade ótima do ARC quando compactado na energia intermediária. Essa maior umidade possibilitaria um processo de hidratação mais efetivo das partículas de cimento presentes no agregado reciclado de concreto.

A Tabela 4.15 apresenta os resultados de módulo tangente a $50 \%$ da tensão de ruptura do agregado reciclado de concreto para ambas as energias empregadas. Esses resultados também são ilustrados na Figura 4.16.

Tabela 4.15 - Resultados de módulo tangente à $50 \%$ da tensão de ruptura do agregado reciclado de concreto

\begin{tabular}{ccc}
\hline \multirow{2}{*}{$\begin{array}{c}\text { TEMPO } \\
\text { (dias) }\end{array}$} & \multicolumn{2}{c}{$E_{\text {TAN 50\% }}$ (MPa) } \\
\cline { 2 - 3 } & ENERGIA MOD. & ENERGIA INTER. \\
\hline 0 & 80 & 62 \\
3 & 88 & 81 \\
7 & 108 & 96 \\
28 & 133 & 119 \\
90 & 180 & 166 \\
\hline
\end{tabular}

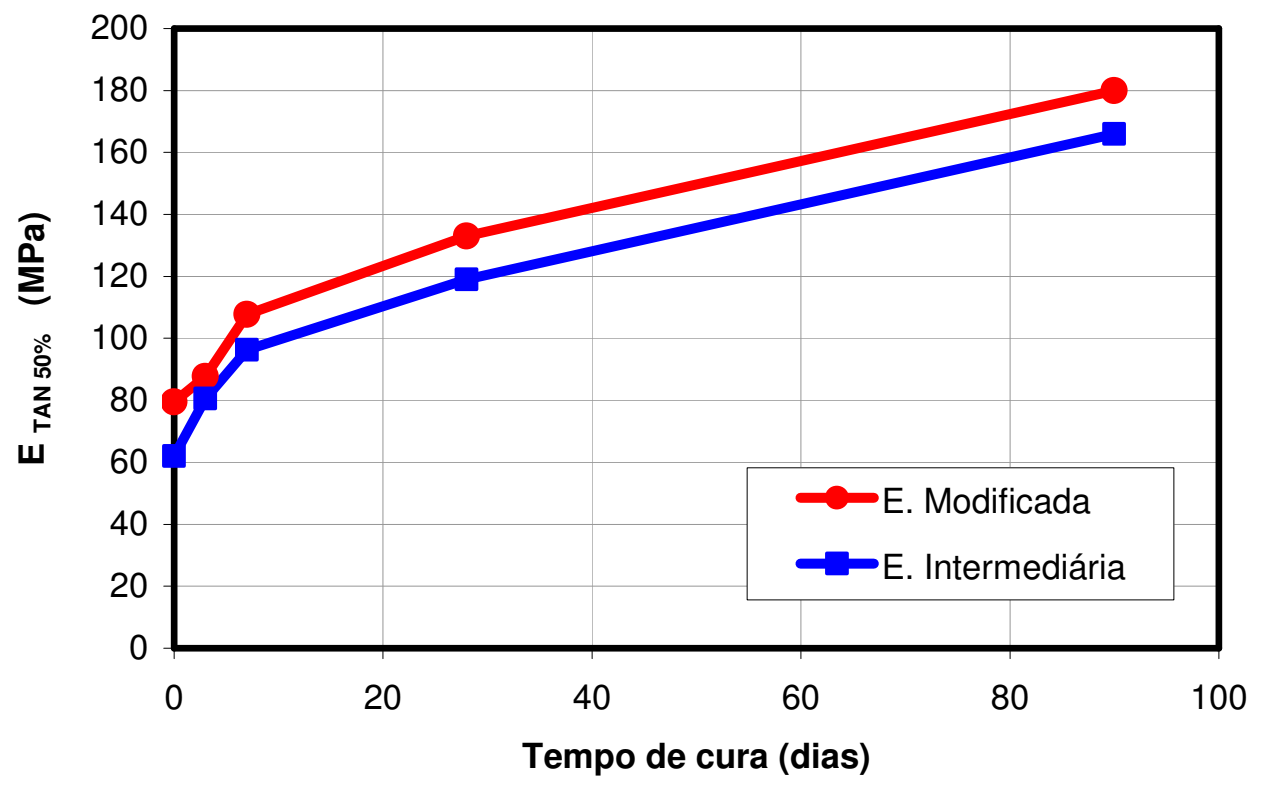

Figura 4.16 - Variação do módulo tangente do ARC ao longo do tempo de cura. 
Analisando-se os resultados apresentados na Tabela 4.15 e ilustrados na Figura 4.16, verifica-se que, assim como ocorreu no caso da resistência à compressão simples, a rigidez do agregado reciclado de concreto, em ambas as energias pesquisadas, também aumentou consideravelmente ao longo do tempo. Comparando-se os valores encontrados para a energia modificada, nota-se que o módulo tangente obtido para o período de 90 dias é $125 \%$ maior do que 0 determinado para o período de 0 dia. Quando se faz a mesma comparação para a energia intermediária, constata-se que essa diferença é mais expressiva, 168\%.

Finalmente, acredita-se que o aumento de resistência à compressão simples e rigidez do agregado reciclado de concreto ao longo do tempo se deva ao fenômeno de cimentação própria do material. Ressalta-se que tal efeito já havia sido relatado por Arm (2001), Blanknagel (2005) e Poon et al (2006). Observa-se que todos os elementos de concreto e argamassa, mesmo aqueles que já possuem certa idade, apresentam em seu interior partículas de cimento que não tiveram contato com água e conseqüentemente não se hidrataram. Quando esses materiais são britados e transformados em agregado reciclado, algumas dessas partículas têm oportunidade de ter contato com água e se hidratarem. Além disso, no momento da compactação do agregado reciclado, os grãos sofrem ligeiras quebras que possibilitam que mais partículas tenham condição de se hidratarem com a umidade de compactação. Essa hidratação produz uma cimentação dos grãos ao longo do tempo. Esse fenômeno poderia ser comparado à estabilização química de um agregado natural com pequena porcentagem de cimento ou cal. 


\subsubsection{Compressão Diametral}

A Tabela 4.16 apresenta os resultados de resistência à tração por compressão diametral (RTCD) imediata dos materiais pesquisados.

Tabela 4.16 - Resultados de resistência à tração por compressão diametral imediata.

\begin{tabular}{ccc}
\hline MATERIAL & ENERGIA & RCTD $(\mathbf{k P a})$ \\
\hline ARC & Intermediária & 2 \\
ARC & Modificada & 5 \\
ARC-solo & Modificada & 9 \\
Solo & Modificada & 118 \\
Ag. Natural & Modificada & 0 \\
\hline
\end{tabular}

Analisando-se a Tabela 4.16, verifica-se que o agregado reciclado de concreto apresentou baixos valores de resistência à compressão por tração diametral, 2 e $5 \mathrm{kPa}$ paras energias intermediária e modificada, respectivamente. A mistura ARC-solo apresentou uma RTCD de $9 \mathrm{kPa}$, ou seja, a adição de solo ao agregado reciclado de concreto possibilitou um incremento em sua resistência à tração. O agregado natural apresentou resistência à tração nula. Para esse material não foi possível concluir o ensaio, pois o mesmo se rompia ao ser colocado na prensa, simplesmente com o peso do equipamento. Já o solo puro apresentou resistência à tração muito superior aos dos demais materiais. Essa maior resistência à tração do solo em relação aos demais materiais pesquisados já era esperada, uma vez que os agregados não apresentam "coesão" entre partículas, suas resistências são mobilizadas pelo contato grão-a-grão. Quando se aplica um leve esforço de tração, os grãos desses materiais se separam com facilidade.

A Tabela 4.17 apresenta os resultados de resistência à tração por compressão diametral do agregado reciclado de concreto para os tempos de cura de 
0, 3, 7 e 28 dias, para ambas as energias pesquisadas. Esses valores também são ilustrados na Figura 4.17.

Tabela 4.17 - Evolução da resistência à tração do ARC ao longo do tempo.

\begin{tabular}{ccc}
\hline \multirow{2}{*}{$\begin{array}{c}\text { TEMPO } \\
\text { (dias) }\end{array}$} & \multicolumn{2}{c}{ RCTD (kPa) } \\
\cline { 2 - 3 } & ENERGIA MOD. & ENERGIA INTER. \\
\hline 0 & 5 & 2 \\
3 & 8 & 3 \\
7 & 11 & 7 \\
28 & 15 & 11 \\
\hline
\end{tabular}

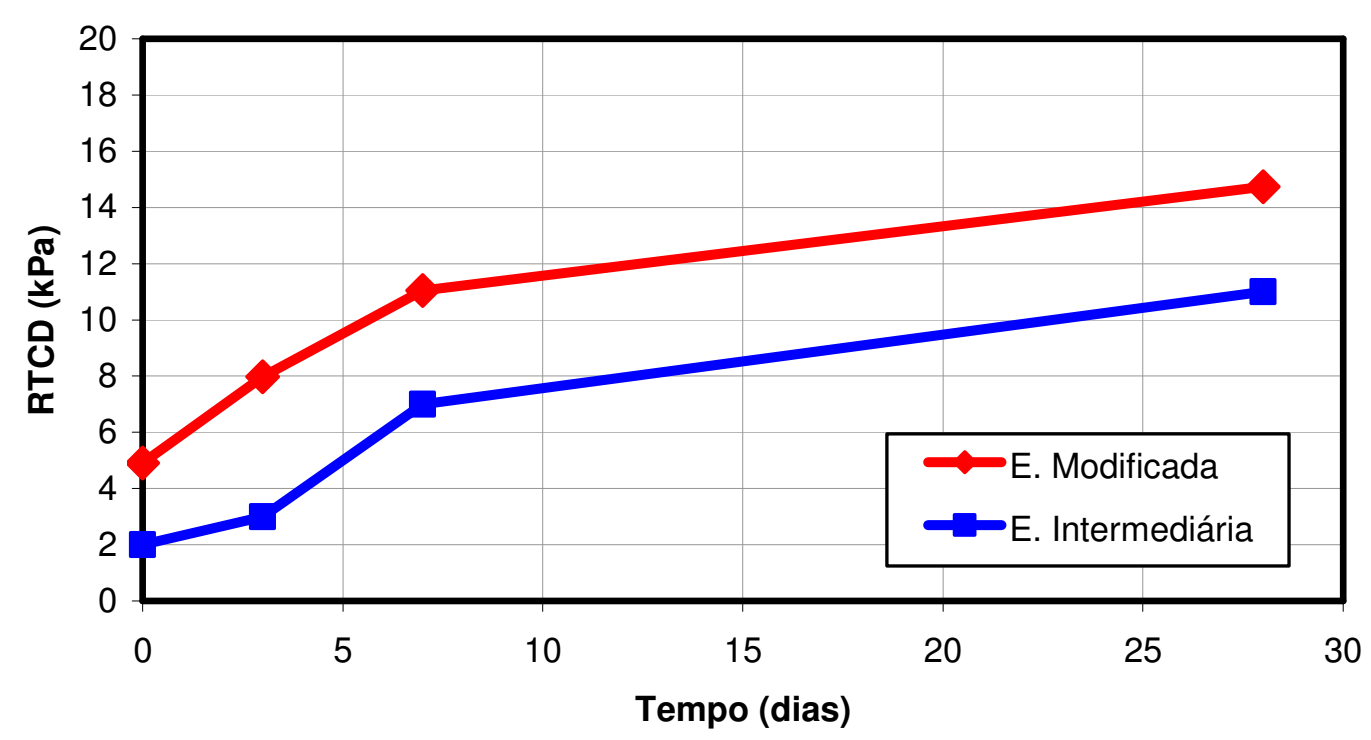

Figura 4.17 - Evolução da resistência à tração do ARC ao longo tempo.

Examinando-se os resultados apresentados na Tabela 4.17 e ilustrados na Figura 4.17, verifica-se que a resistência à tração por compressão diametral (RTCD) do ARC, em ambas as energias de compactação, assim como observado na resistência à compressão simples, cresce com o tempo de cura. Para a energia modificada, verifica-se que a resistência à tração determinada para o período de 28 dias de cura é cerca de três vezes maior do que a obtida imediatamente após a compactação. Quando se faz a mesma análise para a energia intermediária, essa 
diferença é de aproximadamente 5 vezes. Como já mencionado anteriormente, acredita-se que a melhora no comportamento mecânico do agregado reciclado de concreto ao longo do tempo se deva ao efeito da cimentação própria do material.

Por fim, observa-se que os resultados de resistência à tração determinados nesta pesquisa para o agregado reciclado de concreto foram semelhantes aos determinados por Motta (2005) para agregados reciclados mistos, provenientes do Município de São Paulo. Esta pesquisadora relatou que a resistência à tração do agregado reciclado, compactado na energia intermediária, para os vários períodos de cura examinados, se situou em torno de $10 \mathrm{KPa}$.

\subsubsection{Ensaio Triaxial Cíclico}

\subsubsection{Considerações iniciais e resultados}

Os ensaios triaxiais cíclicos foram realizados visando determinar os módulos de resiliência dos materiais pesquisados. No caso do agregado reciclado de concreto, foram analisadas as influências da energia de compactação, intermediária e modificada, e do tempo de cura em câmara úmida, 0 e 90 dias, sobre seu comportamento resiliente. Para os demais materiais, os corpos-de-prova foram compactados na energia modificada e ensaiados sem cura.

Na modelagem da variação do módulo de resiliência com o estado de tensão, foram utilizadas expressões que levam em conta o efeito da tensão confinante (Eq. 4.1), da tensão desvio (Eq. 4.2), das tensões confinante e desvio simultaneamente, 
"modelo composto" (Eq. 4.3) e das tensões volumétricas e cisalhantes octaédricas, "modelo universal da AASTHO" (Eq. 4.4).

$$
\begin{gathered}
M R=K_{1} \sigma_{c}{ }^{K_{2}} \\
M R=K_{1} \sigma_{d}{ }^{K_{2}} \\
M R=K_{1}{\sigma_{c}}^{K_{2}} \sigma_{d}{ }^{K_{3}} \\
M R=K_{1} p_{a}\left(\frac{\theta}{p_{a}}\right)^{K_{2}}\left(\frac{\tau_{o c t}}{p_{a}}+1\right)^{K_{3}}
\end{gathered}
$$

onde:

MR: módulo de resiliência (MPa);

$\sigma_{d}$ : tensão desvio $(\mathrm{kPa})$;

$\sigma_{\mathrm{c}}$ : tensão confinante $(\mathrm{kPa})$;

$\theta$ : primeiro invariante de tensão $=$ tensão volumétrica $(\mathrm{kPa})$;

$\tau_{\text {oct }}:$ tensão cisalhante octaédrica $(\mathrm{kPa})$;

$P_{a}:$ Pressão atmosférica $(\mathrm{kPa})$;

$\mathrm{K}_{1}, \mathrm{~K}_{2}, \mathrm{~K}_{3}$ : parâmetros de regressão.

As Tabelas 4.18 e 4.19 apresentam os valores dos parâmetros de regressão e dos coeficientes de determinação $\left(R^{2}\right)$ dos quatro modelos empregados para o agregado reciclado de concreto e para os demais materiais estudados, respectivamente. 
Tabela 4.18 - Constantes de regressão e $\mathbf{R}^{2}$ para o agregado reciclado de concreto.

\begin{tabular}{|c|c|c|c|c|c|c|}
\hline MODELO & $\begin{array}{l}\text { TEMPO DE } \\
\text { CURA (Dias) }\end{array}$ & $\begin{array}{c}\text { ENERGIA DE } \\
\text { COMPACTAÇÃO }\end{array}$ & $\mathrm{K}_{1}$ & $\mathrm{~K}_{2}$ & $\mathrm{~K}_{3}$ & $\mathbf{R}^{2}$ \\
\hline \multirow{4}{*}{$M R=K_{1} \sigma_{c}^{K_{2}}$} & \multirow{2}{*}{0} & Inter. & 4,3 & 0,84 & - & 0,98 \\
\hline & & Mod. & 8,6 & 0,75 & - & 0,99 \\
\hline & \multirow{2}{*}{90} & Inter. & 20,1 & 0,75 & - & 0,99 \\
\hline & & Mod. & 10,4 & 0,90 & - & 0,87 \\
\hline \multirow{4}{*}{$M R=K_{1} \sigma_{d}^{K_{2}}$} & \multirow{2}{*}{0} & Inter. & 7,5 & 0,64 & - & 0,64 \\
\hline & & Mod. & 14,1 & 0,59 & - & 0,54 \\
\hline & \multirow{2}{*}{90} & Inter. & 76,4 & 0,43 & - & 0,30 \\
\hline & & Mod. & 130 & 0,31 & - & 0,10 \\
\hline \multirow{4}{*}{$M R=K_{1} \sigma_{c}^{K_{2}}{\sigma_{d}}^{K_{3}}$} & \multirow{2}{*}{0} & Inter. & 4,4 & 0,85 & $-0,01$ & 0,98 \\
\hline & & Mod. & 8,5 & 0,74 & 0,01 & 0,99 \\
\hline & \multirow{2}{*}{90} & Inter. & 18,2 & 0,73 & 0,04 & 0,99 \\
\hline & & Mod. & 14,4 & 0,96 & $-0,12$ & 0,88 \\
\hline \multirow{4}{*}{$M R=K_{1} p_{a}\left(\frac{\theta}{p_{a}}\right)^{K_{2}}\left(\frac{\tau_{o c t}}{p_{a}}+1\right)^{K}$} & \multirow{2}{*}{0} & Inter. & 646 & 1,08 & $-0,90$ & 0,96 \\
\hline & & Mod. & 956 & 0,99 & $-0,91$ & 0,99 \\
\hline & \multirow{2}{*}{90} & Inter. & 2179 & 0,99 & $-0,81$ & 0,98 \\
\hline & & Mod. & 1824 & 1,40 & $-1,56$ & 0,89 \\
\hline
\end{tabular}

Tabela 4.19 - Constantes de regressão e $R^{2}$ para o ARC-solo, solo e agregado natural.

\begin{tabular}{cccccc}
\hline MODELO & MATERIAL & $\mathbf{K}_{\mathbf{1}}$ & $\mathbf{K}_{\mathbf{2}}$ & $\mathbf{K}_{\mathbf{3}}$ & $\mathbf{R}^{\mathbf{2}}$ \\
\hline \multirow{2}{*}{$M R=K_{1} \sigma_{c}{ }^{K_{2}}$} & Ag. Natural & 6,6 & 0,81 & - & 0,97 \\
& ARC-solo & 11,4 & 0,70 & - & 0,99 \\
& Solo & 1183 & $-0,16$ & - & 0,66 \\
\hline \multirow{2}{*}{$M R=K_{1} \sigma_{d}{ }^{K_{2}}$} & Ag. Natural & 14,0 & 0,60 & - & 0,49 \\
& ARC-solo & 15,5 & 0,55 & - & 0,62 \\
& Solo & 1313 & $-0,17$ & - & 0,95 \\
\hline \multirow{2}{*}{$M R=K_{1} \sigma_{c}{ }^{K_{2}} \sigma_{d}{ }^{K}$} & Ag. Natural & 5,5 & 0,75 & 0,09 & 0,99 \\
& ARC-solo & 11,7 & 0,72 & $-0,02$ & 0,99 \\
$M R=K_{1} p_{a}\left(\frac{\theta}{p_{a}}\right)^{K_{2}}\left(\frac{\tau_{o c t}}{p_{a}}+1\right){ }^{K_{3}}$ & Solo & 1356 & $-0,03$ & $-0,15$ & 0,96 \\
\hline & Ag. Natural & 817 & 1,03 & $-0,63$ & 0,99 \\
& ARC-solo & 1077 & 1,01 & $-1,01$ & 0,98 \\
& Solo & 7593 & $-0,07$ & $-0,43$ & 0,95 \\
\hline
\end{tabular}

\subsubsection{Influência das tensões aplicadas}

Adotou-se o valor do coeficiente de determinação $\left(\mathrm{R}^{2}\right)$ obtido na regressão dos modelos constitutivos como critério para medida da adequação de cada modelo na representação da variação do módulo de resiliência com o estado de tensão. 
Assim, analisando-se os coeficientes de determinação $\left(R^{2}\right)$ apresentados nas Tabelas 4.18 e 4.19, observa-se, conforme o esperado, que os módulos de resiliência dos materiais granulares pesquisados (ARC, ARC-solo e agregado natural) apresentam boa correlação com o modelo que considera somente a tensão confinante (Eq. 4.2) e baixa correlação com o que depende somente da tensão desvio (Eq. 4.1). Para o solo, material fino, classificado como LG', A-7-5 e ML, de acordo com as classificações MCT, HRB e USCS, respectivamente, o comportamento se inverte e o MR apresenta boa correlação com o modelo que leva em consideração somente a tensão desvio e uma baixa correlação com o que considera somente a tensão confinante.

Considerando todos os materiais pesquisados, pode-se verificar que o modelo composto (Eq. 4.3) e o da AASTHO (Eq. 4.4) foram os que apresentaram melhores desempenhos, com valores de $\mathrm{R}^{2}$ acima de $88 \%$. Apesar dos dois modelos apresentarem desempenhos equivalentes, devido à tendência observada no Brasil de se privilegiar o modelo composto, as análises seguintes serão efetuadas com base no modelo composto. As Figuras 4.18 a 4.24 ilustram tridimensionalmente 0 comportamento resiliente, a partir do modelo em questão, para os materiais pesquisados. 


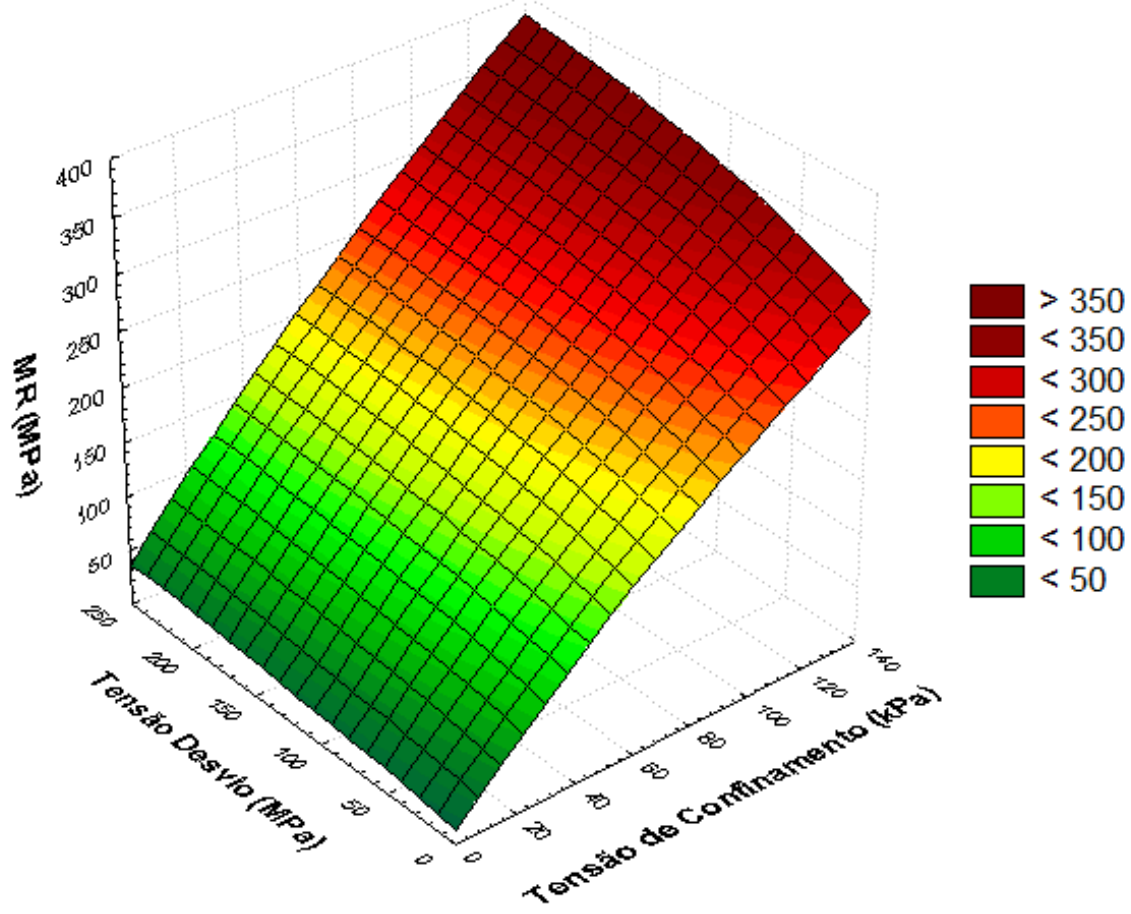

Figura 4.18 - Representação tridimensional do modelo composto para o agregado natural.

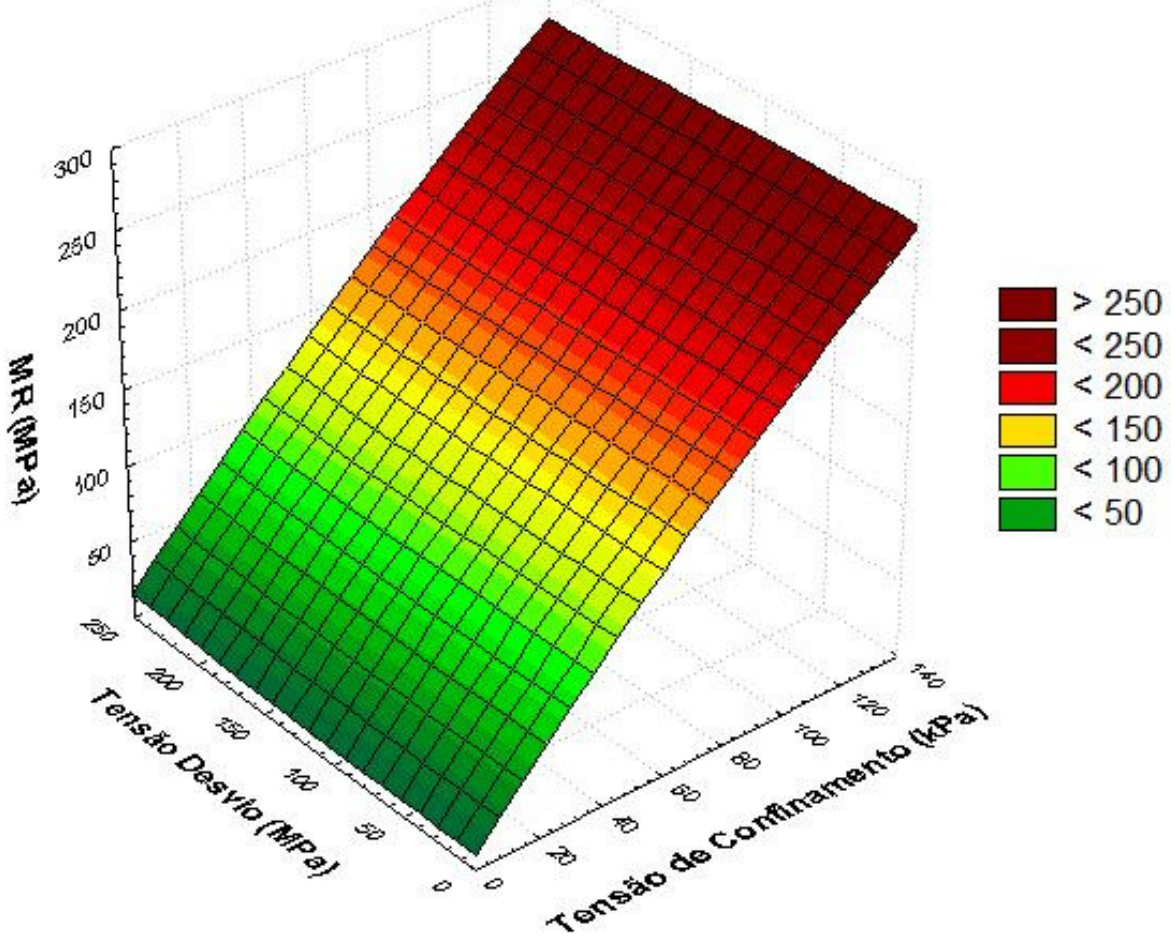

Figura 4.19 - Representação tridimensional do modelo composto para ARC com 0 dia de cura e compactado na energia intermediária. 


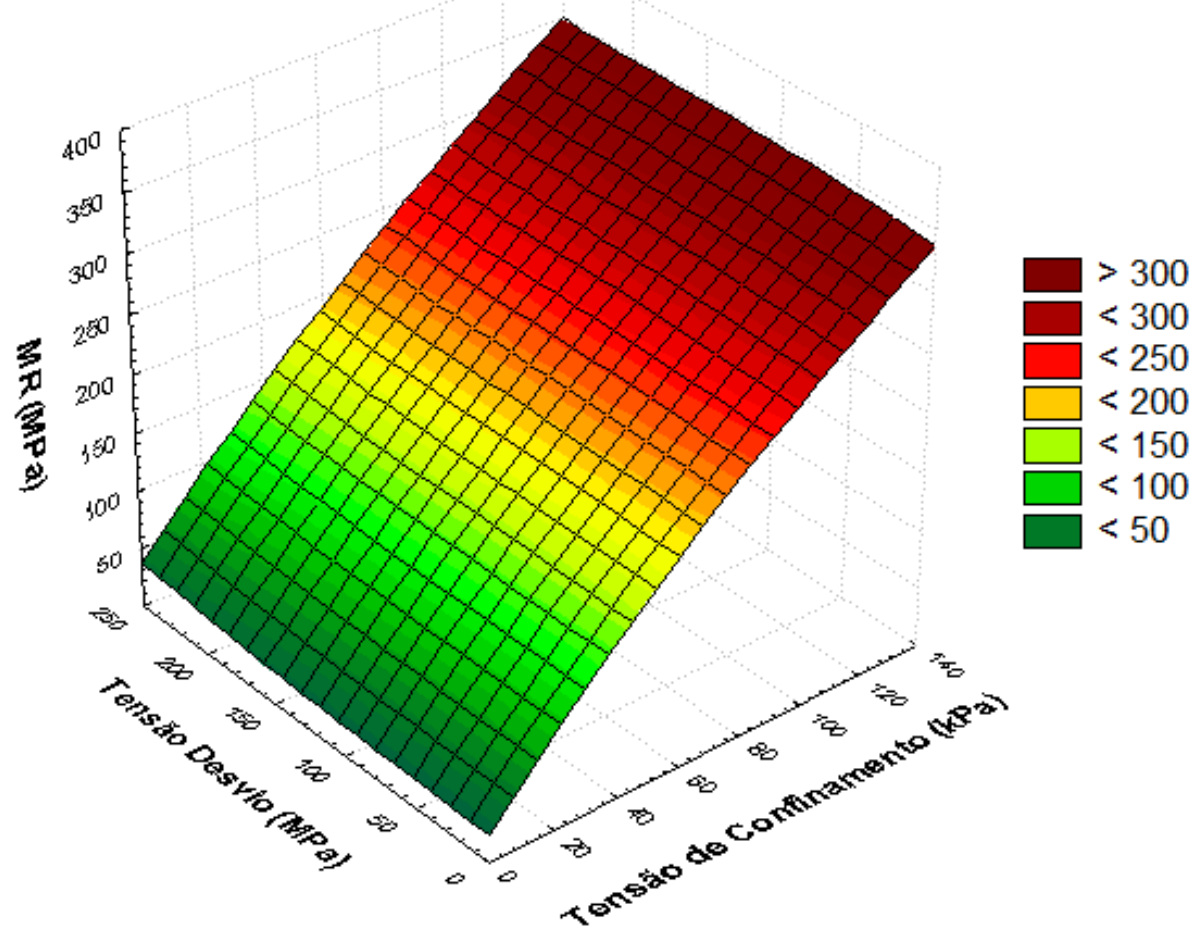

Figura 4.20 - Representação tridimensional do modelo composto para ARC com 0 dia de cura e compactado na energia modificada.

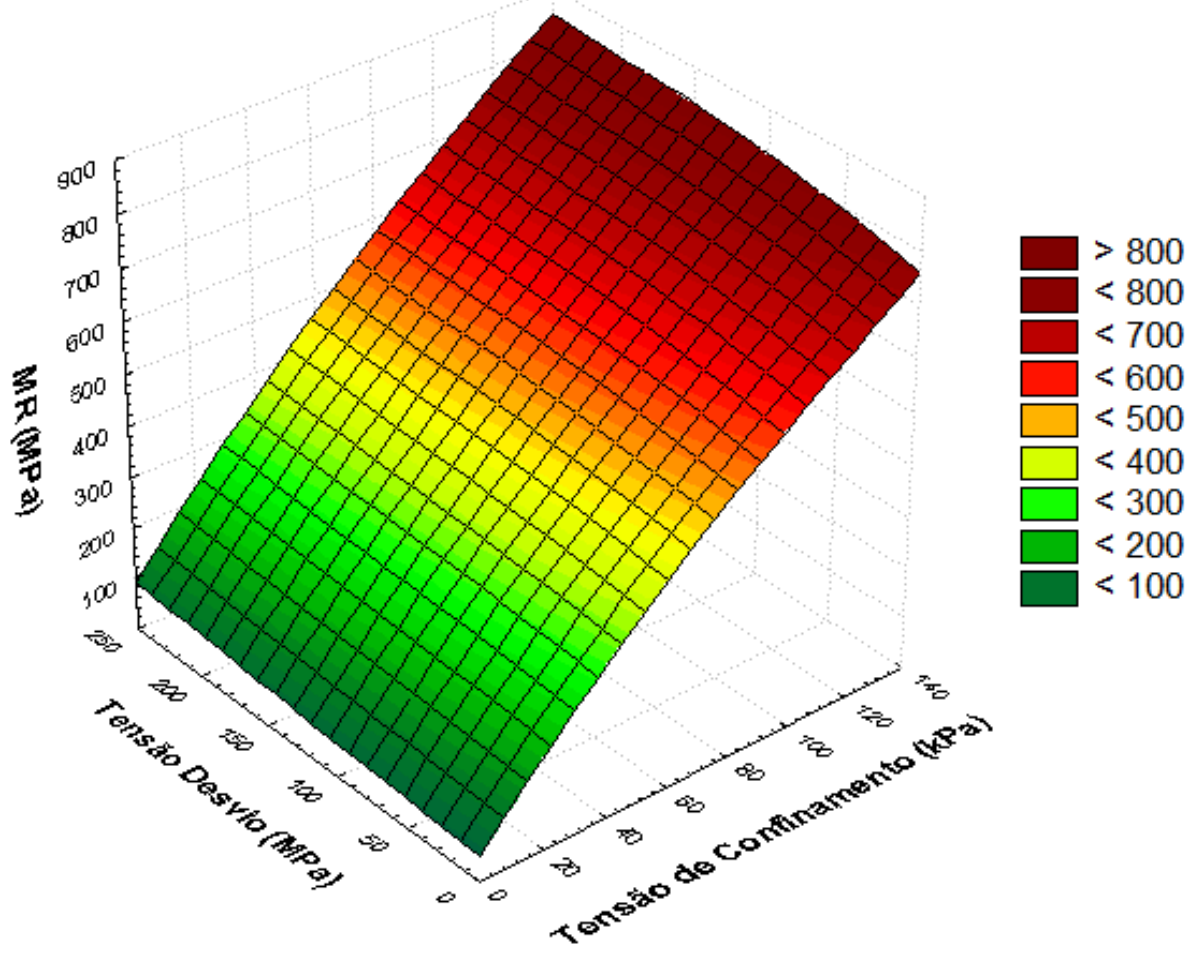

Figura 4.21 - Representação tridimensional do modelo composto para ARC com 90 dia de cura e compactado na energia intermediária. 


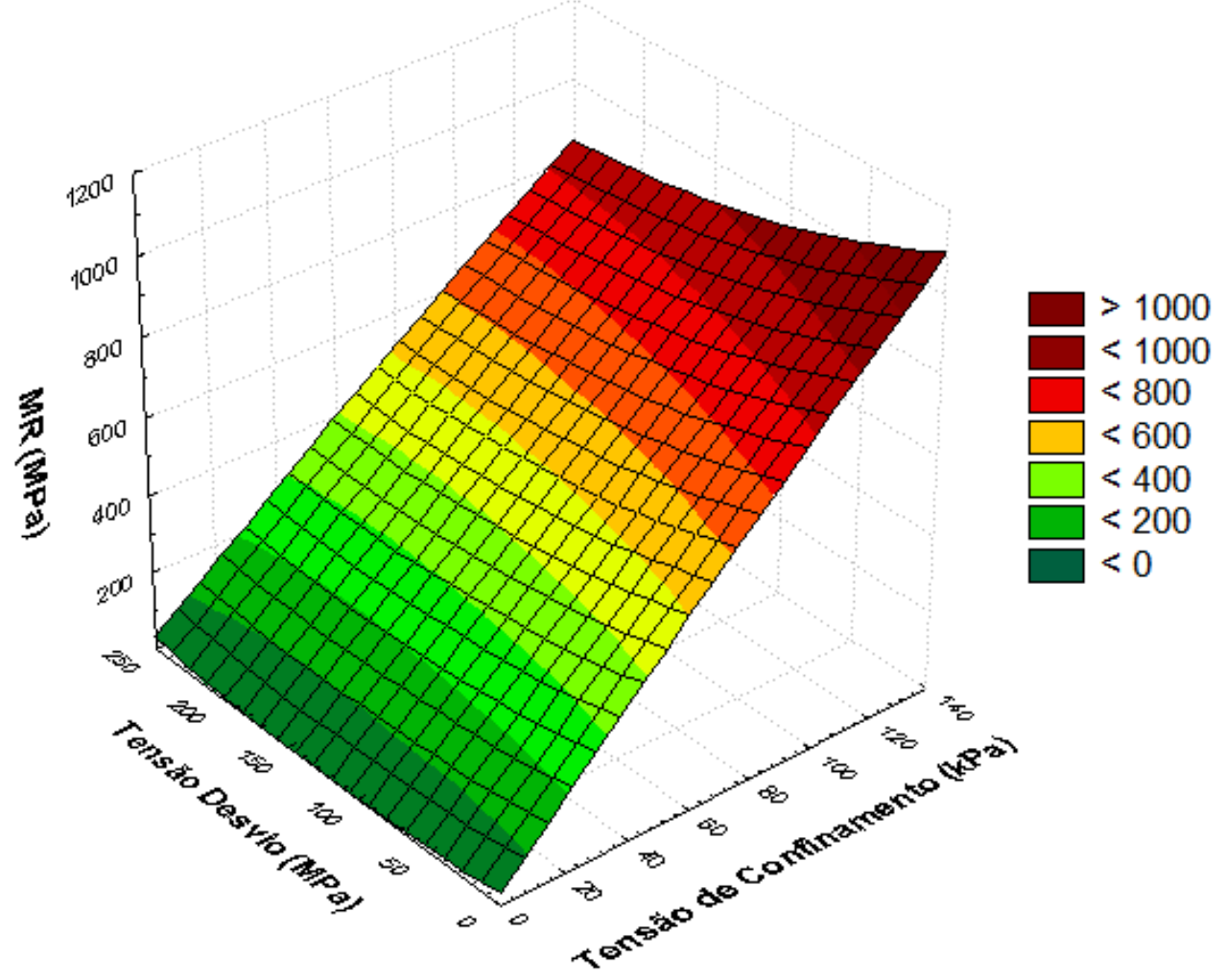

Figura 4.22 - Representação tridimensional do modelo composto para ARC com 90 dia de cura e compactado na energia modificada.

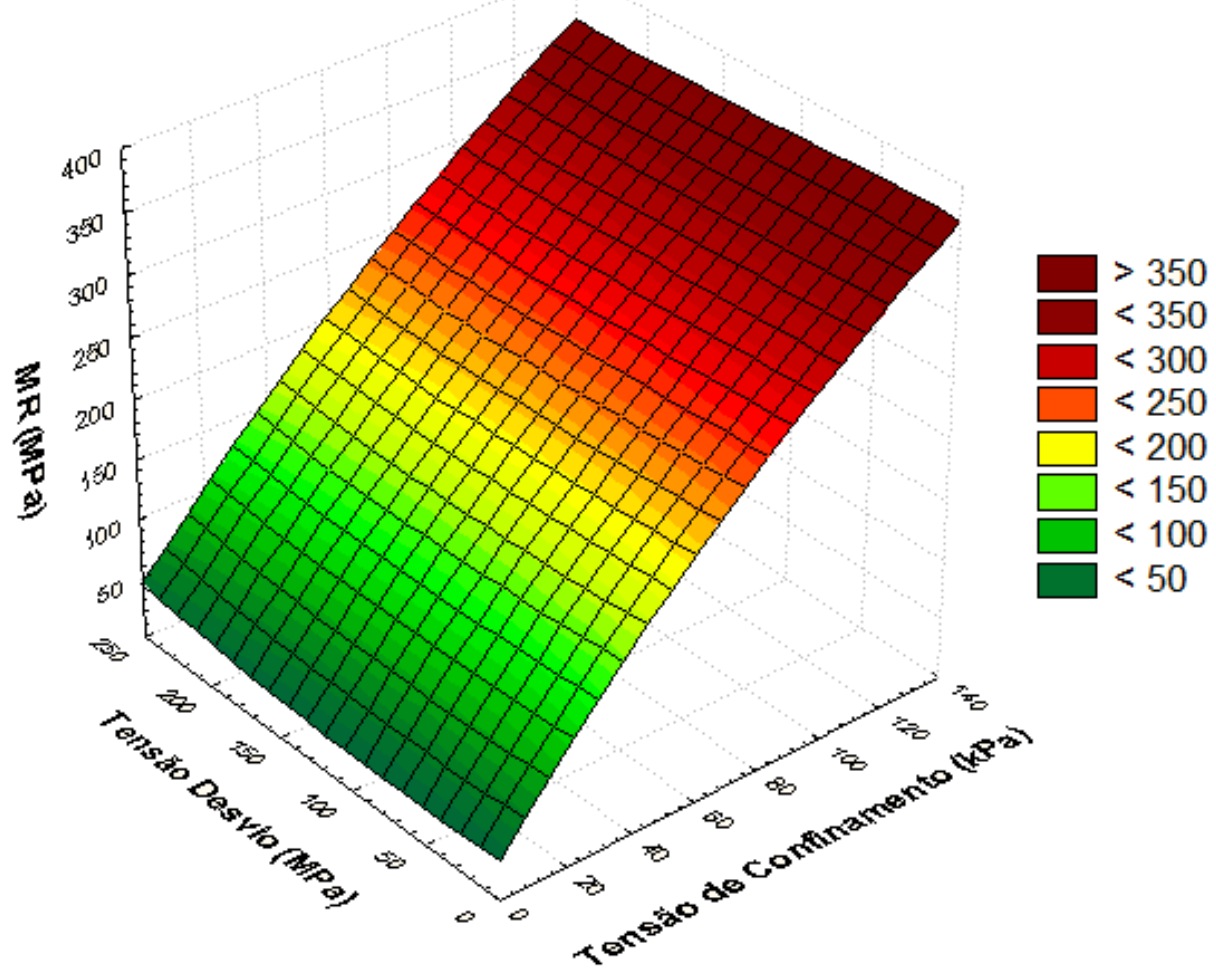

Figura 4.23 - Representação tridimensional do modelo composto para ARC-solo com 0 dia de cura e compactado na energia modificada. 


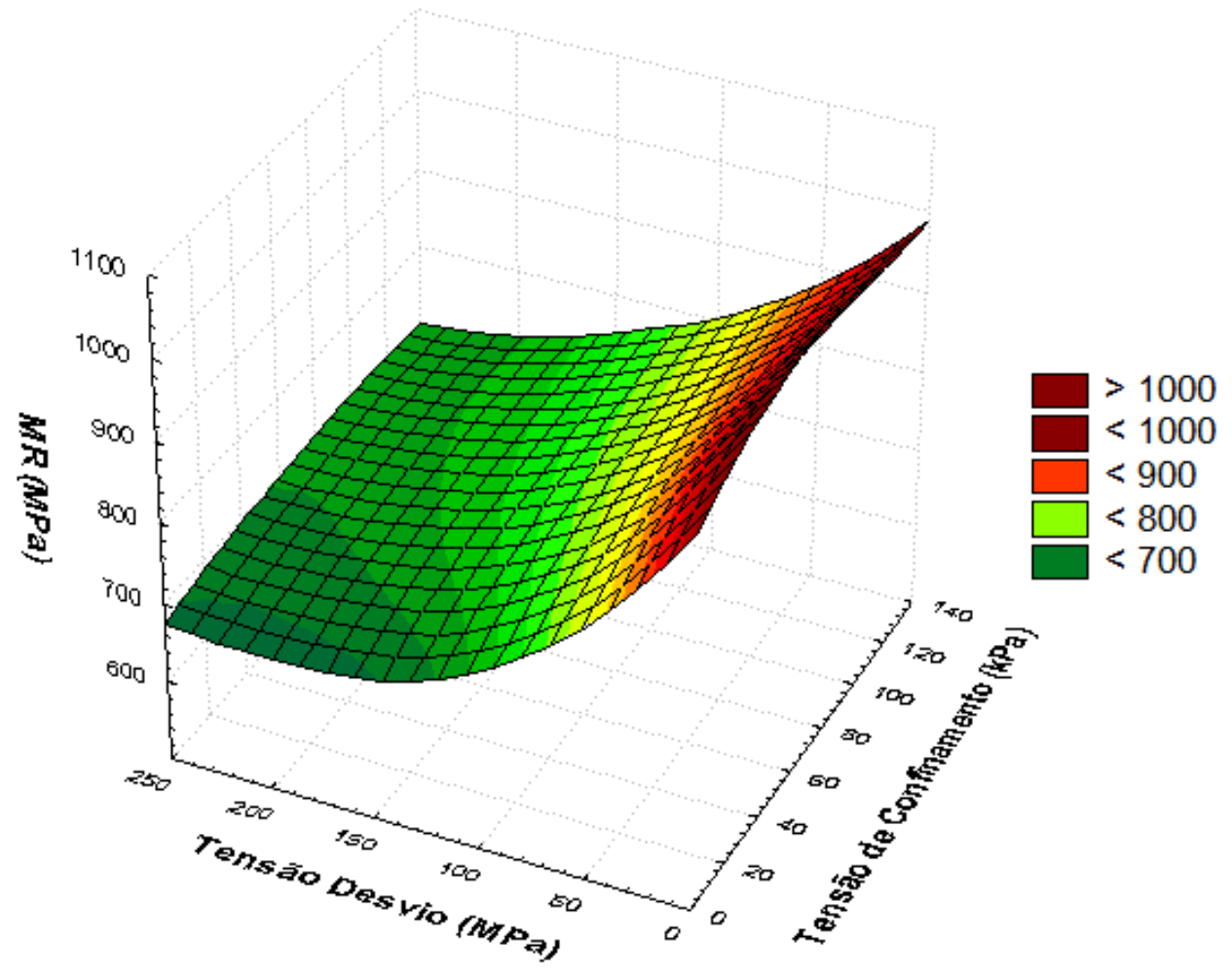

Figura 4.24 - Representação tridimensional do modelo composto para solo com 0 dia de cura e compactado na energia modificada.

Analisando-se as Tabelas 4.18 e 4.19 , com base na Eq. 4.3, e conforme ilustrado nas Figuras 4.18 a 4.24, observa-se que a influência da tensão confinante $\left(\sigma_{c}\right)$ na variação do MR ocorre segundo o esperado, ou seja, os materiais granulares, ARC, ARC-solo e agregado natural, apresentam $\mathrm{K}_{2}$ positivos, indicando que $\mathrm{o}$ incremento de $\sigma_{\mathrm{c}}$ concorre para o aumento de MR. Já para o solo, a tensão confinante não apresenta influência na variação do $M R$, visto que os valores de $K_{2}$ são próximos de zero.

No tocante à influência da tensão desvio $\left(\sigma_{\mathrm{d}}\right)$, observa-se que para os materiais granulares os valores de $\mathrm{K}_{3}$ são próximos de zero, indicando que a $\sigma_{\mathrm{d}}$ não tem influência sobre o MR, com as exceções do ARC compactado na energia 
modificada, curado por 90 dias (ARC-M-90) e do agregado natural. Considerando-se essas exceções, verifica-se que para o ARC-M-90, o valor de $\mathrm{K}_{3}$ é negativo, embora, em módulo, bem inferior ao de $\mathrm{K}_{2}$. Já para o agregado natural, ao contrário do esperado, o valor de $\mathrm{K}_{3}$ é positivo. Contudo, ressalta-se que outros pesquisadores já relaram resultados semelhantes, como por exemplo, Darous (2003), ao estudar a brita corrida proveniente da Pedreira Ibrata. Finalmente, observa-se que para o solo,

a influência da tensão desvio ocorre conforme o esperado, isto é, o $K_{3}$ apresenta valor negativo, indicando que variação positiva nesta tensão acarreta perda de rigidez.

\subsubsection{Avaliação do módulo de resiliência em função da tensão confinante}

Com a finalidade de se comparar o comportamento dos materiais granulares compactados na energia modificada ensaiados sem cura, a Figura 4.25 ilustra a variação do MR com a tensão confinante. Esta representação foi utilizada tendo-se em vista que este modelo apresentou elevados valores de correlação para esses materiais e também pelo fato de permitir uma visualização bidimensional do problema. Analisando-se essa figura, observa-se que os valores de módulo de resiliência alcançados pela mistura ARC-solo são maiores que os obtidos pelo agregado reciclado de concreto e pelo agregado natural para todos os níveis de tensão, embora, destaca-se que estes são muito próximos entre si. Quando se compara o agregado reciclado de concreto com o agregado natural, verifica-se que os dois materiais apresentam módulos de resiliência praticamente iguais. Ou seja, o comportamento resiliente do agregado reciclado de concreto é muito semelhante ao 
observado para o material convencionalmente empregado em camadas de base de pavimentos.

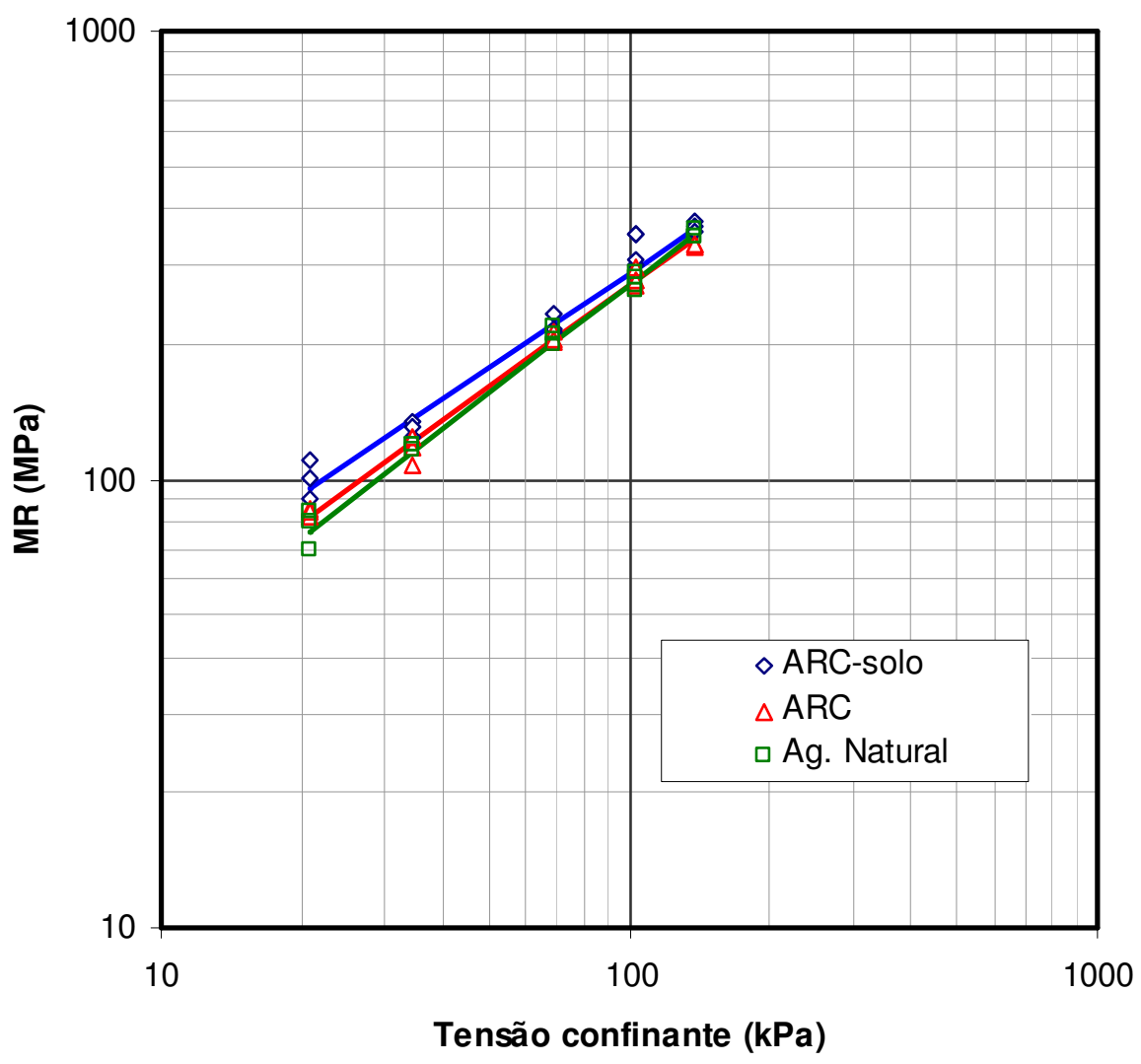

Figura 4.25 - Variação do MR com a tensão confinante para os materiais granulares compactados na energia modificada.

Ainda na Figura 4.25, verifica-se que com a variação da menor tensão para a maior tensão confinante empregadas no ensaio triaxial cíclico, ou seja, de $20,7 \mathrm{kPa}$ para $137,9 \mathrm{kPa}$, respectivamente, o módulo de resiliência médio dos materiais granulares compactados na energia modificada sem cura aumenta em $270 \mathrm{MPa}$, variando de $80 \mathrm{MPa}$ para 350MPa.

A Figura 4.26 ilustra as curvas de variação de módulo de resiliência em função da tensão confinante para o agregado reciclado de concreto, compactado nas energias intermediária e modificada, e ensaiado sem cura e aos 90 dias de cura. 


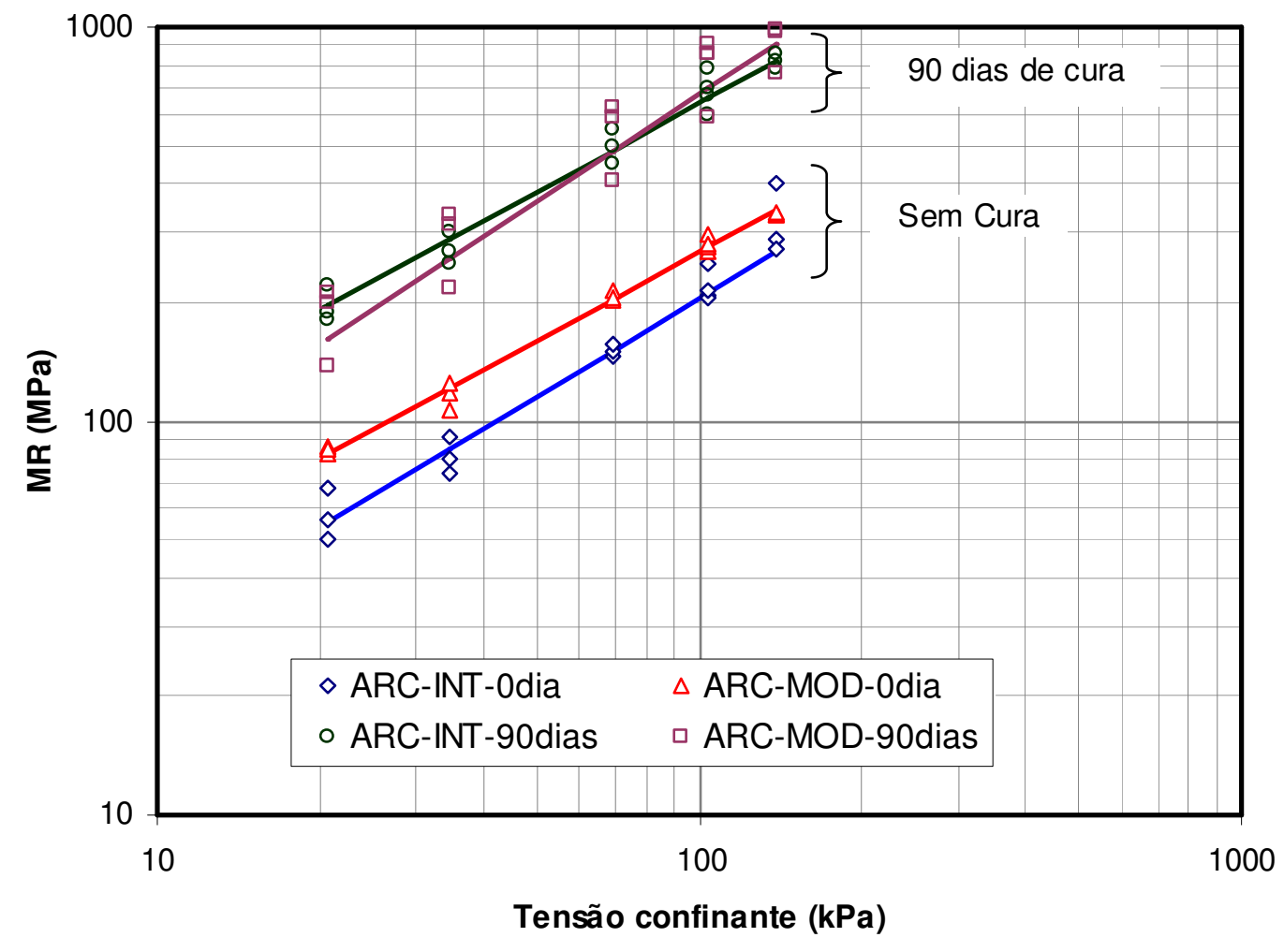

Figura 4.26 - Variação do MR do ARC com a tensão confinante.

Analisando-se a Figura 4.26, verifica-se que para a condição sem tempo de cura, o agregado reciclado de concreto compactado na energia modificada apresenta maiores valores de módulo de resiliência do que o mesmo compactado na energia intermediária, para todos os níveis de tensão. Entretanto, examinando-se as curvas obtidas para o tempo de cura de 90 dias, nota-se que o ARC compactado nas energias modificada e intermediária apresentam valores de MR muito próximos entre si. Destaca-se que esse fato já havia sido observado para a resistência à compressão simples. Conforme dito anteriormente, para os períodos de cura iniciais, acredita-se que o melhor comportamento do ARC alcançado quando empregada a energia modificada se deva à maior densidade do material, mobilizando, assim, um maior atrito interno. Com o passar do tempo de cura, esse efeito é encoberto pela hidratação das partículas de cimento presentes no agregado reciclado, ou seja, o 
efeito da coesão do material, decorrente da cimentação, passa a preponderar sobre o efeito do atrito interno.

Ainda na Figura 4.26, nota-se que o agregado reciclado de concreto apresenta sensível aumento de módulo de resiliência entre os períodos de 0 dia e 90 dias. Considerando-se a energia modificada, observa-se que para a menor tensão confinante empregada no ensaio, $20,7 \mathrm{kPa}$, o ARC apresenta um ganho de MR para esse intervalo de tempo de aproximadamente $95 \%$, já para a maior tensão confinante, 137,9 kPa, esse ganho é em torno de 160\%. Quando se considera a energia intermediária, o ARC apresenta ganhos de MR de aproximadamente $250 \%$ e $200 \%$, respectivamente, para a menor e para a maior tensão confinante. Acredita-se que o aumento de rigidez do agregado reciclado de concreto observado para ambas energias de compactação se deva a cimentação própria do material, repetindo o comportamento observado para a resistência à compressão simples.

\subsubsection{Avaliação do MR para uma estrutura de pavimento hipotética}

Com o objetivo de facilitar a comparação dos resultados e também apresentar uma aplicação prática, calculou-se, a partir do modelo composto, o módulo de resiliência de cada material para o centro da camada de base de uma estrutura de pavimento hipotética. Supôs-se um carregamento composto por duas rodas do eixo padrão, distantes entre si em $30 \mathrm{~cm}$, com raio de carregamento igual $10,8 \mathrm{~cm}$. A Figura 4.27 ilustra a estrutura considerada, enquanto a Tabela 4.20 apresenta suas principais características. Destaca-se que para a escolha dos parâmetros, considerou-se uma estrutura compatível com baixos e médios volumes de tráfego, 
portanto, em conformidade com o nível de tráfego recomendado pela norma NBR 15.115 (ABNT, 2004e) para o emprego de resíduos de construção e demolição em camadas de base e sub-base de pavimentos $\left(\mathrm{N} \leq 10^{6}\right.$ repetições do eixo-padrão de $80 \mathrm{kN}$ no período de projeto).

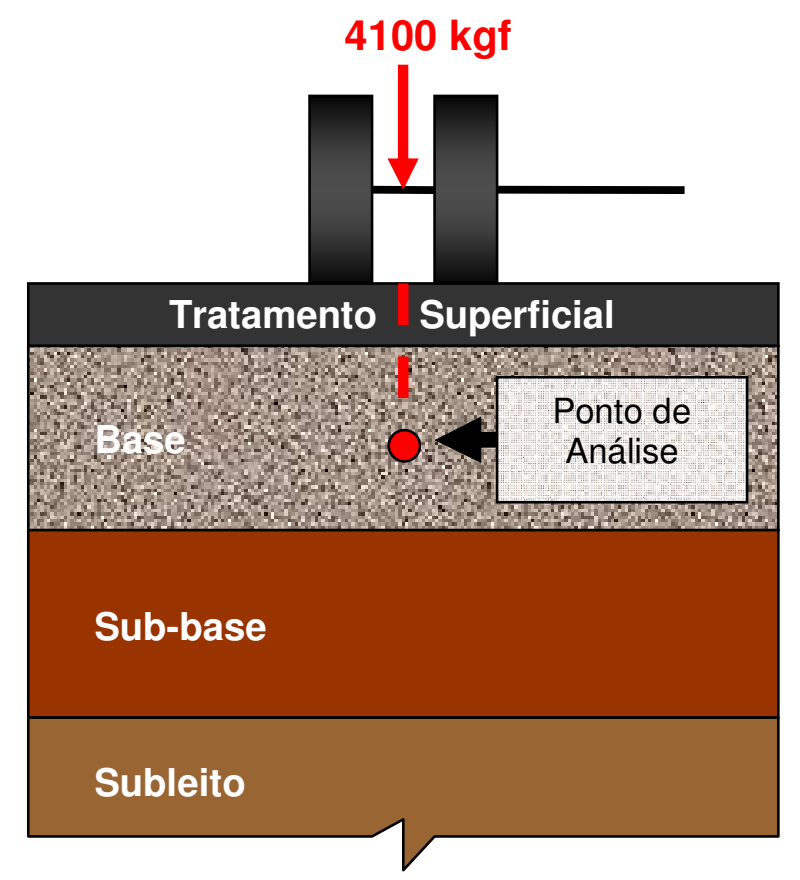

Figura 4.27 - Estrutura do pavimento hipotético considerada na análise do MR.

Tabela 4.20 - Características da estrutura do pavimento hipotético.

\begin{tabular}{cccc}
\hline CAMADA & ESPESSURA & $\begin{array}{c}\text { COEFICIENTE } \\
\text { DE POISSON (v) }\end{array}$ & $\begin{array}{c}\text { MR } \\
(\mathbf{M P a})\end{array}$ \\
\hline Tratamento Superficial & $2,5 \mathrm{~cm}$ & 0,4 & 1500 \\
Base & $15,0 \mathrm{~cm}$ & 0,35 & - \\
Sub-base & $15,0 \mathrm{~cm}$ & 0,35 & 90 \\
Subleito & Semi-infinito & 0,35 & 45 \\
\hline
\end{tabular}

A análise do módulo de resiliência foi realizada através do programa computacional ELSYM 5 por meio de um processo iterativo de cálculo. Primeiramente, adotava-se um valor de módulo de resiliência e calculavam-se as tensões no centro da camada de base da estrutura proposta. Em seguida, a partir dessas tensões, determinava-se um novo valor de MR no modelo composto, o qual 
"alimentava" novamente no programa. Esse procedimento era realizado até que os valores convergissem. A Tabela 4.21 apresenta os módulos de resiliência calculados.

Tabela 4.21 - Valores de MR calculados para o centro da camada de base da estrutura proposta.

\begin{tabular}{cccc}
\hline AMOSTRA & ENERGIA & $\begin{array}{c}\text { TEMPO DE } \\
\text { CURA (dias) }\end{array}$ & $\begin{array}{c}\text { MR } \\
\text { (MPa) }\end{array}$ \\
\hline Agregado Natural & Modificada & 0 & 218 \\
Solo & Modificada & 0 & 640 \\
ARC-solo & Modificada & 0 & 241 \\
\hline \multirow{2}{*}{ ARC } & Intermediária & 0 & 183 \\
& Modificada & 0 & 226 \\
& Intermediária & 90 & 435 \\
& Modificada & 90 & 444 \\
\hline
\end{tabular}

Com base na Tabela 4.21, ilustram-se na Figura 4.28 os módulos de resiliência dos materiais pesquisados, compactados na energia modificada e ensaiados sem cura.

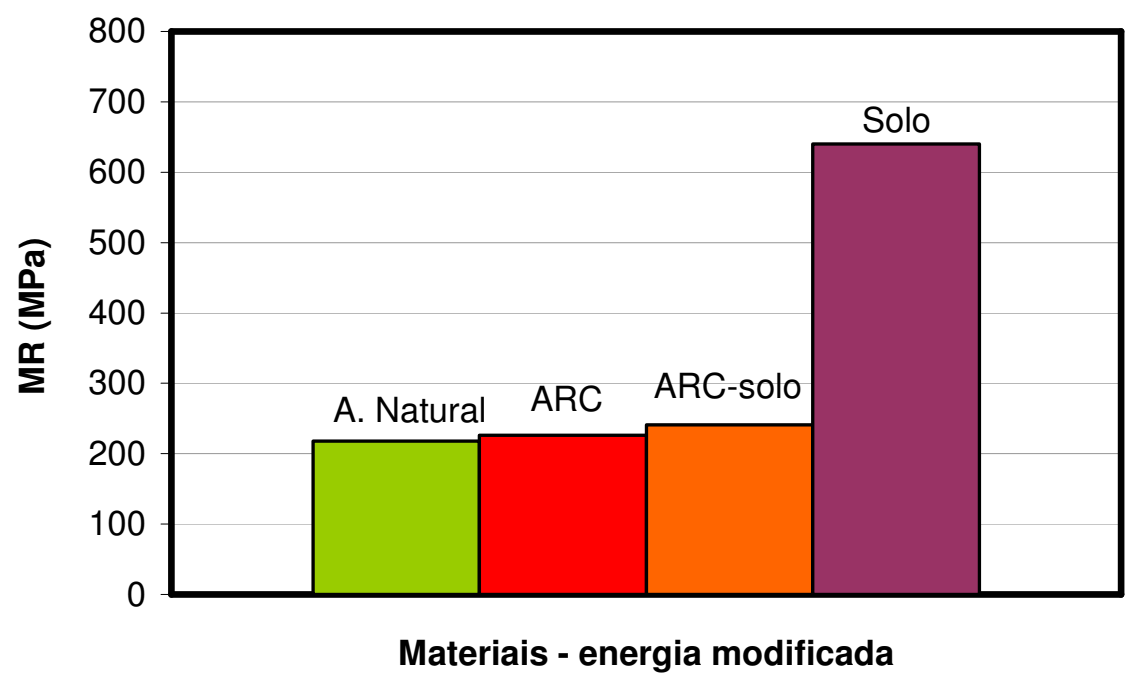

Figura 4.28 - MR dos materiais compactados na energia modificada.

Analisando-se essa a Figura 4.28, verifica-se que o módulo de resiliência do agregado reciclado de concreto é semelhante ao determinado para a mistura ARC- 
solo, isto é, a adição de $25 \%$ de solo ao agregado reciclado de concreto não teve influência significativa sobre este parâmetro. Comparando o agregado reciclado de concreto com o agregado natural, observa-se que seus módulos de resiliência são praticamente iguais, cerca de $220 \mathrm{MPa}$. Entretanto, quando se comparam estes materiais com o solo, verifica-se que o solo apresenta um módulo de resiliência cerca de três vezes maior do que os alcançados pelos agregados. Entretanto, ressalta-se que, embora seja comum que solos argilosos de comportamento laterítico apresentem valores de RCS e de MR superiores aos obtidos para materiais granulares, sua utilização em camadas de base de pavimentos deve ser realizada com cuidado, uma vez que, frente a variações de umidade, podem apresentar perda de desempenho expressiva, ao contrário do verificado para materiais granulares.

Com base na Tabela 4.21, ilustram-se na Figura 4.29 os módulos de resiliência do agregado reciclado de concreto para os tempos de cura de 0 e 90 dias, para ambas as energias de compactação.

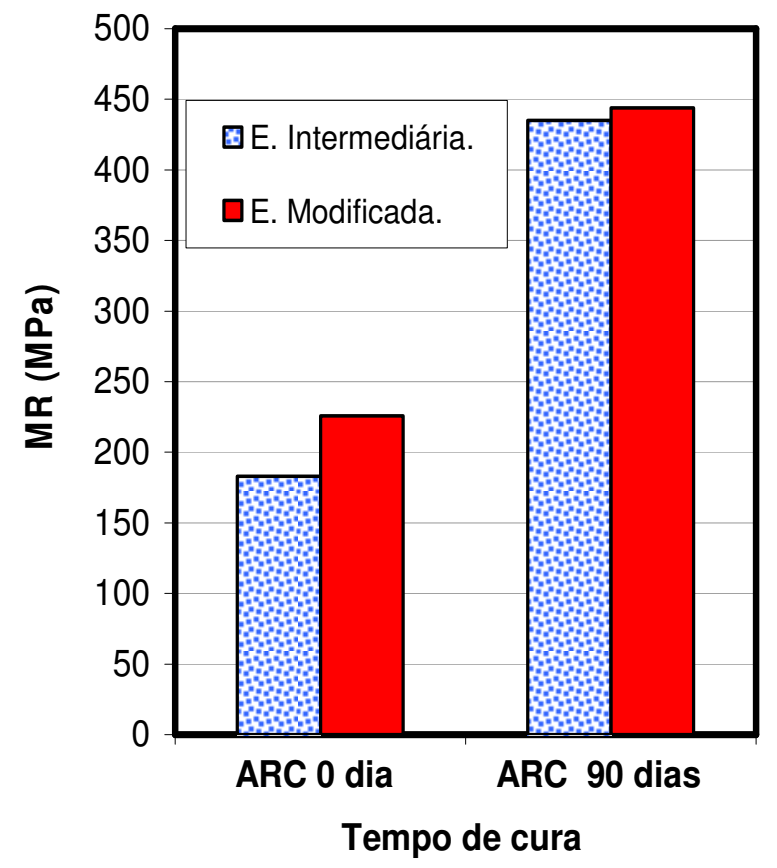

Figura 4.29 - MR dos agregados reciclados de concreto para os tempos de cura de 0 e 90 dias. 
Analisando-se a Figura 4.29, verifica-se que o agregado reciclado de concreto apresenta ganho de módulo de resiliência entre os períodos de 0 e 90 dias para ambas energias empregadas. Esses incrementos de rigidez para as energias modificada e intermediária são de 96\% e 138\%, respectivamente. Como observado anteriormente, acredita-se que essa melhoria de comportamento mecânico do agregado reciclado de concreto com o decorrer do tempo se deva ao fenômeno da cimentação própria do material. Destaca-se que os resultados determinados nesta pesquisa são semelhantes aos obtidos por Arm (2001). Esta pesquisadora relatou que o agregado reciclado de concreto, proveniente da Suécia, compactado na energia modificada, também apresentou valores crescentes de módulo de resiliência com o passar do tempo de cura.

No tocante à influência da energia de compactação sobre o comportamento do agregado reciclado de concreto, ainda analisando-se a Figura 4.29, verifica-se que na condição sem cura, o emprego da energia modificada conduz a um módulo de resiliência $23 \%$ maior que o determinado quando se utiliza a energia intermediária, conforme esperado. Já quando se examina o ARC aos 90 dias de cura, nota-se que a energia de compactação não apresenta mais tal influência sobre sua rigidez, visto que o MR com 90 dias de cura é praticamente igual para as duas energias pesquisadas, cerca de $440 \mathrm{MPa}$. Assim, com o passar do tempo, o efeito sobre o ARC da energia de compactação é encoberto pelo fenômeno da cimentação própria do material, conforme discutido anteriormente. 


\section{CONCLUSÕES}

\subsection{CONSIDERAÇÕES INICIAIS}

Esta pesquisa teve como objetivo estudar as propriedades físicas e o comportamento mecânico, através da análise de resultados de ensaios laboratoriais, do agregado reciclado de concreto proveniente da Usina de Reciclagem de Resíduos da Construção Civil de São Carlos-SP, visando seu emprego em camadas de bases e sub-bases de pavimentos. A título de comparação, também foram avaliados um agregado natural, um solo e uma mistura deste solo com o agregado reciclado de concreto.

É importante ressaltar que todas as conclusões apresentadas neste capítulo restringem-se ao universo dos materiais e das condições pesquisadas.

\subsection{CARACTERIZAÇÃO, CLASSIFICAÇÃO AMBIENTAL E COMPACTAÇÃO}

O agregado reciclado de concreto, em comparação com o agregado natural, apresenta maior absorção de água, menor densidade aparente e maior desgaste ao ensaio de abrasão Los Angeles. Acredita-se que essas diferenças sejam 
decorrentes do agregado reciclado apresentar uma parcela expressiva de argamassa aderida a seus grãos.

Em relação à classificação ambiental, o agregado reciclado de concreto foi considerado de acordo com a norma NBR 10004 (ABNT, 2004a) como pertencente à classe II-A, isto é, material não-perigoso e não-inerte. Entretanto, acredita-se que este fato não deva ser considerado como um fator restritivo para o emprego deste material na construção de camadas de pavimentos, uma vez que até mesmo alguns solos tropicais, sem contaminação aparente, quando classificados de acordo com as prescrições da norma supracitada, são considerados também como não-inertes.

No tocante à compactação, o agregado reciclado de concreto apresenta menor massa específica seca máxima $\left(\rho_{\mathrm{dmax}}\right)$ e maior umidade ótima $\left(\omega_{\mathrm{o}}\right)$ que o agregado natural. Esse fato já era esperado em função de sua maior absorção de água e menor densidade aparente, conforme mencionado anteriormente. Quando se compara o agregado reciclado de concreto com a mistura agregado reciclado de concreto - solo (ARC-solo), o ARC in natura apresenta uma $\rho_{\mathrm{dmax}}$ maior e uma $\omega_{\mathrm{o}}$ semelhante. Considerando-se a influência da energia de compactação para o ARC, o emprego da energia modificada, em relação à energia intermediária, acarreta um aumento na massa específica seca máxima e uma diminuição da umidade ótima, conforme esperado.

No que se refere à degradação do material, o agregado reciclado apresenta quebras menos expressivas durante o processo de compactação do que o relatado em pesquisas envolvendo agregados reciclados mistos, como em Fernandes (2004), 
Motta (2005) e Leite (2007). Acredita-se que essa maior resistência à quebra durante a compactação do $A R C$ em relação aos agregados reciclados mistos se deva a natureza dos seus materiais constituintes.

\subsection{DESEMPENHO DOS MATERIAIS COMPACTADOS NA ENERGIA MODIFICADA, ENSAIADOS SEM CURA}

O agregado reciclado de concreto apresenta um elevado valor de CBR, 182\%, superior aos limites de $20 \%$ e 60\% exigidos pela norma NBR 15115 (ABNT, 2004e) para o emprego de agregados reciclados de resíduos de construção civil em camadas de sub-base e base de pavimentos, respectivamente. Além disso, a capacidade de suporte do agregado reciclado de concreto é superior a dos demais materiais pesquisados. O CBR do agregado natural é de $146 \%$, o do solo $41 \%$ e o da mistura ARC-solo é de $164 \%$. No que tange à expansão, os agregados pesquisados e a mistura ARC-solo apresentam expansão nula e o solo apresenta expansão menor do que $0,3 \%$.

Os valores de resistência à compressão simples (RCS), resistência à tração por compressão diametral (RTCD) e de módulo de resiliência (MR) do agregado reciclado de concreto são próximos aos observados para a mistura de ARC-solo, isto é, a adição do solo ao agregado reciclado não teve influência significativa sobre estes parâmetros.

No tocante ao comportamento resiliente, observa-se que os módulos de resiliência dos materiais granulares pesquisados, ARC, ARC-solo e agregado natural, apresentam boa correlação com o modelo que considera somente a tensão 
confinante e baixa correlação com o que depende somente da tensão desvio. Já para o solo, o comportamento se inverte e o MR apresenta boa correlação com o modelo que leva em consideração somente a tensão desvio e uma baixa correlação com o que considera somente a tensão confinante. Considerando todos os materiais pesquisados, destaca-se que o modelo composto e o da AASTHO são os que apresentam melhores desempenhos, com valores de coeficiente de determinação acima de $88 \%$.

\subsection{AVALIAÇÃO DO TEMPO DE CURA E DA ENERGIA DE COMPACTAÇÃO SOBRE O DESEMPENHO DO ARC}

Analisando-se os resultados dos ensaios de compressão simples, compressão por tração diametral e triaxial cíclico, constata-se que existe uma melhoria ao longo do tempo de cura do comportamento mecânico do agregado reciclado de concreto para ambas energias pesquisadas. Acredita-se que esse fato se deve à cimentação própria do material, tal efeito já havia sido relatado anteriormente por Arm (2001), Blanknagel (2005) e Poon et al (2006). Esse fenômeno poderia ser comparado à estabilização química de um agregado natural com pequena porcentagem de cimento ou cal.

No tocante à energia de compactação, constata-se que este parâmetro tem influência significativa sobre o desempenho do agregado reciclado de concreto ensaiado sem cura. Nesta condição, de acordo com o esperado, o emprego da energia modificada conduz a maiores valores de CBR, RCS, RTCD e MR do que os alcançados quando se utiliza a energia intermediária. No entanto, com o decorrer do tempo de cura, essa influência diminui expressivamente. 


\subsection{CONSIDERAÇÕES FINAIS}

Os resultados desta pesquisa indicam que a utilização de agregados reciclados de concreto pode ser uma interessante alternativa ao emprego de agregados naturais na construção de camadas de base e sub-base de pavimentos.

Por fim, destaca-se que essa forma de reciclagem pode estender a vida útil dos aterros pela diminuição da deposição dos resíduos de construção e demolição e das jazidas minerais pela substituição do agregado natural pelo agregado reciclado, portanto, mitigando os impactos ambientais, e conseqüentemente, promovendo o desenvolvimento sustentável.

\subsection{RECOMENDAÇÕES PARA TRABALHOS FUTUROS}

Para o melhor conhecimento do comportamento de agregados reciclados de concreto, sugere-se:

- Pesquisar agregados reciclados de concreto provenientes de outros municípios;

- Avaliar a influência da umidade pós-compactação sobre o comportamento mecânico de agregados reciclados de concreto;

- Avaliar a deformação permanente de agregados reciclados de concreto, sob condições de carregamentos cíclicos.

- Construir e monitorar o desempenho de trechos experimentais, empregando-se agregados reciclados de concreto proveniente da Usina de Reciclagem de Resíduos de Construção Civil de São Carlos. 
- Realizar avaliações econômicas sobre o emprego de agregados reciclados de concreto na construção de camadas de base e sub-base de pavimentos. 


\section{REFERÊNCIAS BIBLIOGRÁFICAS}

\section{AMERICAN ASSOCIATION OF STATE HIGHWAY AND TRANSPORTATION}

OFFICIALS. AASHTO T 307-99: Standard method of test for determining the resilient modulus of soils and aggregate materials, 1999.

ASSOCIAÇÃO BRASILEIRA DE NORMAS TÉCNICAS. NBR 7181: Solo - Análise granulométrica. Rio de Janeiro, 1984a.

NBR 7182: Solo - Ensaio de compactação. Rio de Janeiro, 1984b.

NBR 10004: Resíduos sólidos - Classificação. Rio de Janeiro, 2004a.

NBR 15112: Resíduos da construção civil e resíduos volumosos - Áreas de transbordo e triagem - Diretrizes para projeto, implantação e operação. Rio de Janeiro, 2004b.

NBR 15113: Resíduos sólidos da construção civil e resíduos inertes - Aterros Diretrizes para projeto, implantação e operação. Rio de Janeiro, 2004c.

NBR 15114: Resíduos sólidos da construção civil - Áreas de reciclagem Diretrizes para projeto, implantação e operação. Rio de Janeiro, 2004d.

NBR 15115: Agregados reciclados de resíduos sólidos da construção civil Execução de camadas de pavimentação - Procedimentos. Rio de Janeiro, 2004e.

NBR 15116: Agregados reciclados de resíduos sólidos da construção civil Utilização em pavimentação e preparo de concreto sem função estrutural Requisitos. Rio de Janeiro, 2004 f.

ANGULO, S. C. Caracterização de agregados de resíduos de construção e demolição reciclados e a influência de suas características no comportamento mecânico de concretos. 2005. 167 p. Tese (Doutorado) Universidade de São Paulo, São Paulo, 2005.

ARM, M. Self-cementing properties of crushed demolished concrete in unbound layers: results from triaxial tests and field tests. Waste Management and Research, v.21, p.235-239, 2001. 
BENNERT, T.; PAPP JR., W. J.; MAHER, A.; GUCUNSKI, N. Utilization of construction and demolition debris under traffic-type loading in base and subbase applications. Transportation Research Record, n.1714, p.33-39, 2000.

BIDONE, F. R. A; POVINELLI, J. Conceitos básicos de resíduos sólidos: Francisco Ricardo Andrade Bidone, Jurandyr Povinelli. São Carlos: EESC/USP, 1999. 109p.

BLANKENAGEL, B. J. Characterization of recycled concrete for use as pavement base material. 2005. 66p. Dissertação (Mestrado) - Department of Civil and Environmental Engineering Brigham Young University, Provo, 2005.

BLANKENAGEL, B. J.; GUTHRIE, W. S. Laboratory characterization of recycled concrete for use as pavement base material. Transportation Research Record, n.1952, p.21-27, 2006.

BODI, J.; BRITO FILHO, J. A.; ALMEIDA, S. Utilização de entulho de construção civil reciclado na pavimentação urbana. In: Reunião Anual de Pavimentação, 29., Cuiabá, 1995. Anais. ABPv, 1995. p.409-436.

CARNEIRO, A. P.; BURGOS, P. C.; ALBERTE, E. P. V. Uso do agregado reciclado em camadas de base e sub-base de pavimentos. Projeto Entulho Bom. Salvador: EDUFBA / Caixa Econômica Federal, 2001. p.190-227.

CAtapreta, C. A. A.; PEREIRA, J. C.; AlmeidA, A. H. Avaliação do desempenho das usinas de reciclagem de resíduos de construção civil de Belo Horizonte, Brasil. In: XXXI Congresso Interamericano AIDIS, Santiago, 2008. Anais AIDIS, 2008.

COPPEAD. Índices de transporte rodoviário. Instituto de Pós-graduação e Pesquisa em Administração, Universidade Federal do Rio de Janeiro. Rio de Janeiro, 2007. Disponível em:

<http://www.centrodelogistica.com.br/new/_IndicesRodoviariosV7.pdf>. Acesso em: 23 de dez. 2008

CONSELHO NACIONAL DO MEIO AMBIENTE. Brasília. 2002. Resolução CONAMA no 307, de 5 de julho de 2002. Disponível em: <http://www.mma.gov.br/port/conama/res/res02/res30702.html>. Acesso em: 04 de ago. 2008.

DAROUS, J. Estudo comparativo entre sistemas de cálculo de tensões e deformações utilizados em dimensionamento de pavimentos asfálticos novos. 2003. 170p. Dissertação (Mestrado) Coordenação dos Programas de Pós-Graduação de Engenharia, Universidade Federal do Rio de Janeiro (COPPE-UFRJ). Rio de Janeiro, 2003.

DIAS. J. F. Avaliação de resíduos da fabricação de telhas cerâmicas como contribuição para seu emprego em camadas de pavimentos de baixo 
custo. 2004. 204p. Tese (Doutorado) - Escola Politécnica, Universidade de São Paulo. São Paulo, 2004.

DEPARTAMENTO NACIONAL DE ESTRADAS DE RODAGEM. DNER-ME 049/94: Determinação do Índice de Suporte Califórnia utilizando amostras não trabalhadas. Rio de Janeiro, 1994.

DNER-ES 303/97: Pavimentação - base estabilizada granulometricamente. Rio de Janeiro, 1997.

. DNER-PRO 120/97: Coleta de amostras de agregados. Rio de Janeiro, 1997.

DNER-ME 035/98: Agregados - Determinação da abrasão “Los Angeles”. Rio de Janeiro, 1998a.

DNER-ME 081/98: Agregados - Determinação da absorção e da massa específica de agregado graúdo. Rio de Janeiro, 1998b.

EUROPEAN COMMISSION. 2000. Management of construction and demolition waste. Disponível em:

<ec.europa.eu/enterprise/environment/index_home/waste_management/constr_ dem_waste_000404.pdf >. Acesso em: 04 de ago. 2008.

EPA - ENVIRONMENTAL PROTECTION AGENCY - MUNICIPAL AND INDUSTRIAL SOLID WASTE DIVISION - OFFICE OF SOLID WASTE. United States. 1998. Report no EPA530-R-98-010 - Characterization of buildingrelated construction and demolition debris in the United States. Disponível em: <http://www.p2pays.org/ref/02/01095.pdf. Acesso em: 04 de ago. 2008.

FAGURY, S. C.; GRANDE, F. M. Gestão de Resíduos de Construção e Demolição (RCD) - aspectos legais da gestão pública de São Carlos/SP. Exata, São Paulo, v. 5, n. 1, jan./jun, p. 35-45. 2007

FERNANDES, C. G. Caracterização mecanística de agregados reciclados de resíduos de construção e demolição dos municípios do Rio de Janeiro e de Belo Horizonte para uso em pavimentação. 2004. 109p. Dissertação (Mestrado) - Coordenação dos Programas de Pós-Graduação de Engenharia, Universidade Federal do Rio de Janeiro (COPPE-UFRJ). Rio de Janeiro, 2004.

FHWA - FEDERAL HIGHWAY ADMINISTRATION U.S. DEPARTMENT OF TRANSPORTATION, United States. 1997. Report no FHWA-RD-97-148 - User Guidelines for waste and by-product materials in pavement construction. Disponível em: <http://www.rmrc.unh.edu/resources/cd/userguide/begin.htm>. Acesso em: 04 de ago. 2008.

FHWA - FEDERAL HIGHWAY ADMINISTRATION U.S. DEPARTMENT OF TRANSPORTATION, United States. 2000. Report no FHWA-PL-00-025 Recycled materials in european highway environments: Uses, technologies, and policies. Disponível em: < 
http://international.fhwa.dot.gov/pdfs/recycolor.pdf>. Acesso em: 04 de ago. 2008.

FHWA - FEDERAL HIGHWAY ADMINISTRATION U.S. DEPARTMENT OF TRANSPORTATION, United States. 2004. Transportation Applications of Recycled Concrete Aggregate. FHWA State of the Practice National Review September 2004. Disponível em:

<http://www.rmrc.unh.edu/resources/pandd/rcareport/rcareport.pdf>. Acesso em: 04 de ago. 2008.

HANSEN, T.C. Recycled of demolished concrete and mansory. London: Chapman \& Hall, 1992. 316p. p. 1-160.

HUANG, W.L.; LIN, D. H.; CHANG, N. B.; LIN, K. S.; Recycling of construction and demolition waste via a mechanical sorting process. Resources, Conservation and Recycling, n 37, p. 23-37, 2002.

IBGE - INSTITUTO BRASILEIRO DE GEOGRAFIA E ESTATíSTICA. Perfil dos municípios brasileiros: Gestão pública 2001 / IBGE, Coordenação de População e Indicadores Sociais. - Rio de Janeiro: IBGE, 2001. 245p.

INSTITUTO DE PESQUISAS TECNOLÓGICAS. Lixo municipal: Manual de gerenciamento integrado / coord. M.L.O. D'Almeida, A. Vilhena. 2. ed. São Paulo : IPT/CEMPRE, 2000. $370 \mathrm{p}$.

KLINSKY, L.M.G. Proposta de reaproveitamento de areia de fundição em subbases e bases de pavimentos flexíveis, através de sua incorporação a solos argilosos. 2008. 189p. Dissertação (Mestrado) - Escola de Engenharia de São Carlos, Universidade de São Paulo. 2008.

KUO, S.; MAHGOUB, H.S.; NAZEF, A. Investigation of recycled concrete made with limestone aggregate for a base course in flexible pavement. Transportation Research Record, n.1787, p.99-108, 2002.

LAURITZEN, E. K. Economic and environmental benefits of recycling waste from the construction and demolition of buildings. Industry and Environment, Paris, v. 17, n.2, abr./jun. p. 26-31,1994

LEITE, F. C. Comportamento mecânico de agregado reciclado de resíduo sólido da construção civil em camadas de base e sub-base de pavimentos. 185p. Dissertação (Mestrado) - Universidade de São Paulo, São Paulo, 2007.

MARQUES, J. C. Gestão dos resíduos de construção e demolição no Brasil / José da Costa Marques Neto. 1a ed. São Carlos: RIMA, 2005. 152 p.

MENDES, T. A.; REZENDE, L. R.; OLIVEIRA, J. C.; GUIMARÃES, R. C.; CARVALHO, J. C.; VEIGAS, R. Parâmetros de uma pista experimental executada com entulho reciclado. In: Reunião Anual de Pavimentação, 35, Rio de Janeiro, 2004. Anais ABPv, 2004. 
MOLENAAR, A. A. A.; VAN NIEKERK, A A. Effects of gradation, composition, and degree of compaction on the mechanical characteristics of recycled unbound materials. Transportation Research Record, n.1787, p.73-82, 2002.

MOREIRA, J. F.; DIAS, J. F.; REZENDE, M. E. Utilização de resíduos de construção e demolição em base de pavimentos na cidade de Uberlândia-MG. Vias Gerais, Fev. 2007. p. 49-54, 2007.

MOTTA, R. S. Estudo laboratorial de agregado reciclado de resíduo sólido da construção civil para aplicação em pavimentação de baixo volume de tráfego. 2005. 134p. Dissertação (Mestrado) - Universidade de São Paulo, São Paulo, 2005.

MEDINA, J. ; MOTTA, L. M. G. Mecânica dos pavimentos. $2^{\text {a }}$ Edição, Rio de Janeiro, 2005.

MENDES, T. A.; REZENDE, L. R.; OLIVEIRA, J. C.; GUIMARÃES, R. C.; CARVALHO, J. C.; VEIGAS, R. Parâmetros de uma pista experimental executada com entulho reciclado. In: Reunião Anual de Pavimentação, 35, Rio de Janeiro, 2004. Anais ABPv, 2004.

NATAATMADJA A., TAN, Y. L. Resilient response of recycled concrete road aggregates. Journal of Transportation Engineering, set-out, p. 450-453, 2001.

NUNES, K. R. A. Avaliação de investimentos e de desempenho de centrais de reciclagem para resíduos sólidos de construção e demolição. 2004. 276p. Tese (Doutorado) - Coordenação dos Programas de Pós-Graduação de Engenharia, Universidade Federal do Rio de Janeiro (COPPE-UFRJ). Rio de Janeiro, 2004.

OLIVEIRA, J. C. Indicadores de potencialidades e desempenho de agregados reciclados de resíduos sólidos da construção civil em pavimentos flexíveis. 2007. 167p. Tese (Doutorado) - Universidade de Brasília, Brasília, 2007.

PARREIRA, A. B.; CARMO, C. A. T.; CUNHO, F. J. C. Estudo do módulo de resiliência de materiais usados em pavimentação. In: Reunião Anual de Pavimentação, 3.. Anais. São Paulo. 1998. ABPV v.1, p. 233-247.

PINTO, T. P. Metodologia para a gestão diferenciada de resíduos sólidos da construção urbana. 1999. 189p. Tese (Doutorado) - Escola Politécnica, Universidade de São Paulo. São Paulo, 1999.

PREFEITURA DO MUNICÍPIO DE SÃO PAULO. São Paulo. 1998. São Paulo em números. Disponível em: <http://portal.prefeitura.sp.gov.br/secretarias/planejamento/sp_em_numeros>. Acesso em: 27 de fev. 2008. 
PMSP - PREFEITURA DO MUNICÍPIO DE SÃO PAULO. São Paulo. 2003.

PMSP/SP ETS - 001/2003 - Camadas de reforço do subleito, sub-base e base mista de pavimento com agregado reciclado de resíduos sólidos da construção civil. Disponível em:

<http://ww2.prefeitura.sp.gov.br//arquivos/secretarias/infraestruturaurbana/norm as_tecnicas_de_pavimentacao/pmspets0012003.pdf>. Acesso em: 04 de ago. 2008.

PMSP - PREFEITURA DO MUNICÍPIO DE SÃO PAULO. São Paulo, 2008. Uso de entulho reciclado torna-se obrigatório na capital. Disponível em:

$<$ http://www.prefeitura.sp.gov.br/portal/a_cidade/noticias/index.php?p=14065>. Acesso em: 26 de novembro de 2008.

PMSP - PREFEITURA DO MUNICÍPIO DE SÃO PAULO. São Paulo, 2008. Tabela de custos. Disponível em:

$<$ http://portal.prefeitura.sp.gov.br/secretarias/infraestruturaurbana/tabela_de_pr ecos/0021 >. Acesso em: 26 de novembro de 2008

PARK, T. Application of construction and building debris as base and subbase materials in rigid pavement. Journal of Transportation Engineering, set-out, p. 558-563, 2003.

PETRARCA, R. W.; GALDIERO, V. A. Summary of testing of recycled crushed concrete. Transportation Research Record, n.973, p.19-26, 1984.

PINTO, T. P. Gestão dos resíduos de construção e demolição em áreas urbanas da ineficácia a um modelo de gestão sustentável. Projeto Entulho Bom.

Salvador: EDUFBA / Caixa Econômica Federal, 2001. p.78-113.

POON, C. S; QIAO, X. C; CHAN, D. Feasible use of recycled concrete aggregates and crushed clay brick as unbound road sub-base. Construction and Building Materials, no 20, p. 578-585, 2006.

RAO, A.; JHA, K.; MISRA, S. Use of aggregates from recycled construction and demolition waste in concrete. Resources, Conservation and Recycling, no 50, p. 71-81, 2007.

SAEED, A; HAMMONS, M. I.; REED, J. L. Comprehensive Evaluation, Design, and Construction Techniques for Airfield Recycled Concrete Aggregate as Unbound Base. In: Transportation Research Board 86th Annual Meeting, Washington DC, United States, 2007. 16p.

SANDLER, K. Analyzing what's recyclable in C\&D debris. Biocycle, no 20, novembro, p. 51-54, 2003.

SANTOS, E. C. G. Aplicação de resíduos de construção e demolição reciclados (RCD-R) em estruturas de solo reforçado. 2007. 168p. Dissertação

(Mestrado) - Escola de Engenharia de São Carlos, Universidade de São Paulo, São Paulo, 2007. 
SCHNEIDER, D. M. Deposições irregulares de resíduos da construção civil na cidade de São Paulo. 2003. 130p. Dissertação (Mestrado) - Faculdade de Saúde Pública, Universidade de São Paulo. São Paulo, 2003.

SILVA JÚNIOR, W. S. Estudo da Utilização de Resíduo da Fabricação de Papel na Construção Rodoviária. 2009. Dissertação em andamento (Mestrado) Escola de Engenharia de São Carlos, Universidade de São Paulo. 2009

SINDICATO DA INDÚSTRIA DA CONSTRUÇÃO CIVIL DO ESTADO DE SÃO PAULO, SINDUSCON-SP. Gestão Ambiental de Resíduos da Construção Civil: A experiência do SindusCon-SP/ Tarcísio de Paula Pinto. São Paulo: SINDUSCON-SP, 2005. 48 p.

SYMONDS GROUP. Construction and demolition waste management practices, and their economic impacts. Disponível em:

$<$ http://ec.europa.eu/environment/waste/studies/cdw/cdw_report.htm>. Acesso em: 04 de ago. 2008.

WILBURN, D. R; GOONAN T. G. U.S. Geological Survey Circular 1176 Aggregates from Natural and Recycled Sources: Economic Assessments for Construction application/ Materials flow analysis. Disponível em: $<$ http://greenwood.cr.usgs.gov/pub/circulars/c1176/c1176.html>. Acesso em: 04 de ago. 2008. 


\section{ANEXO I - CARACTERIZAÇÃO}

Tabela 1 - Características físicas dos agregados.

\begin{tabular}{lccc}
\hline \multirow{2}{*}{ CARACTERÍstICAS } & \multicolumn{2}{c}{ TIPO DE AGREGADO } \\
& \multirow{2}{*}{ ARC } & AG. NATURAL \\
\hline \multirow{3}{*}{ Abrasão Los } & \multirow{2}{*}{ Graduação B } & 22 & 22 \\
Angeles (\%) & 36 & 18 \\
\cline { 2 - 4 } & \multirow{2}{*}{ Graduação C } & 34 & 17 \\
& & 30 & 24 \\
& 32 & 19 \\
Absorção do agregado graúdo (\%) & 4,62 & 22 \\
\hline \multirow{2}{*}{ Densidade aparente do agregado } & 4,52 & 2,21 \\
\multicolumn{2}{c}{ graúdo } & 2,395 & 2,795 \\
\hline
\end{tabular}




\section{ANEXO II - COMPRESSÃO SIMPLES}

Tabela 1 - Teste de Grubbs - RCS - ARC - Energia Modificada.

\begin{tabular}{|c|c|c|c|c|c|c|}
\hline $\begin{array}{l}\text { Tempo } \\
\text { (Dias) }\end{array}$ & $\begin{array}{l}\text { RCS } \\
(\mathrm{kPa})\end{array}$ & $\begin{array}{c}\text { Média } \\
\text { (kPa) }\end{array}$ & $\begin{array}{l}\text { Desv. } \\
\text { Padrão }\end{array}$ & G & Outlier & $\begin{array}{c}\text { Nova média } \\
(\mathrm{kPa})\end{array}$ \\
\hline & 298 & & & 1,14 & não & \\
\hline \multirow[t]{3}{*}{0} & 350 & 336 & 33 & 0,42 & não & 336 \\
\hline & 360 & & & 0,72 & não & \\
\hline & 473 & & & 0,58 & não & \\
\hline \multirow[t]{3}{*}{3} & 473 & 480 & 12 & 0,58 & não & 473 \\
\hline & 494 & & & 1,15 & $\operatorname{sim}$ & \\
\hline & 604 & & & 0,52 & não & \\
\hline \multirow[t]{3}{*}{7} & 617 & 543 & 117 & 0,63 & não & 611 \\
\hline & 408 & & & 1,15 & sim & \\
\hline & 769 & & & 1,07 & não & \\
\hline \multirow[t]{3}{*}{28} & 790 & 787 & 17 & 0,16 & não & 787 \\
\hline & 803 & & & 0,91 & não & \\
\hline & 990 & & & 1,13 & não & \\
\hline \multirow[t]{2}{*}{90} & 1004 & 998 & 7 & 0,77 & não & 998 \\
\hline & 1001 & & & 0,36 & não & \\
\hline
\end{tabular}


Tabela 2 - Teste de Grubbs - $\mathrm{E}_{\mathrm{TAN}, 50 \%}-\mathrm{ARC}$ - Energia Modificada.

\begin{tabular}{|c|c|c|c|c|c|c|}
\hline $\begin{array}{l}\text { Tempo } \\
\text { (Dias) }\end{array}$ & $\begin{array}{c}\mathrm{E}_{\mathrm{TAN}, 50 \%} \\
\text { (MPa) }\end{array}$ & $\begin{array}{l}\text { Média } \\
(\mathrm{MPa})\end{array}$ & $\begin{array}{l}\text { Desv. } \\
\text { Padrão }\end{array}$ & $\mathbf{G}$ & Outlier & $\begin{array}{l}\text { Nova média } \\
\quad(\mathrm{MPa})\end{array}$ \\
\hline \multirow{3}{*}{0} & 79 & & & 0,61 & não & \multirow{3}{*}{80} \\
\hline & 80 & 88 & 15 & 0,54 & não & \\
\hline & 106 & & & 1,15 & $\operatorname{sim}$ & \\
\hline \multirow{3}{*}{3} & 97 & & & 0,98 & não & \multirow{3}{*}{88} \\
\hline & 88 & 88 & 10 & 0,04 & não & \\
\hline & 78 & & & 1,02 & não & \\
\hline \multirow{3}{*}{7} & 136 & & & 0,70 & não & \multirow{3}{*}{108} \\
\hline & 126 & 108 & 41 & 0,45 & não & \\
\hline & 61 & & & 1,15 & não & \\
\hline \multirow{3}{*}{28} & 141 & & & 1,00 & não & \multirow{3}{*}{133} \\
\hline & 133 & 133 & 8 & 0,00 & não & \\
\hline & 125 & & & 1,00 & não & \\
\hline \multirow{3}{*}{90} & 258 & & & 1,15 & $\operatorname{sim}$ & \multirow{3}{*}{180} \\
\hline & 185 & 206 & 45 & 0,46 & não & \\
\hline & 175 & & & 0,68 & não & \\
\hline
\end{tabular}

Tabela 3 - Teste de Grubbs - RCS - ARC - Energia Intermediária.

\begin{tabular}{|c|c|c|c|c|c|c|}
\hline $\begin{array}{l}\text { Tempo } \\
\text { (Dias) }\end{array}$ & $\begin{array}{l}\mathrm{RCS} \\
(\mathrm{kPa})\end{array}$ & $\begin{array}{c}\text { Média } \\
(\mathrm{kPa})\end{array}$ & $\begin{array}{l}\text { Desv. } \\
\text { Padrão }\end{array}$ & G & Outlier & $\begin{array}{l}\text { Nova média } \\
\quad(\mathrm{kPa})\end{array}$ \\
\hline \multirow{4}{*}{0} & 112 & \multirow{4}{*}{179} & \multirow{4}{*}{47} & 1,43 & $\operatorname{sim}$ & \multirow{4}{*}{201} \\
\hline & 190 & & & 0,23 & não & \\
\hline & 192 & & & 0,28 & não & \\
\hline & 222 & & & 0,92 & não & \\
\hline \multirow{3}{*}{3} & 196 & \multirow{3}{*}{256} & \multirow{3}{*}{52} & 1,14 & não & \multirow{3}{*}{256} \\
\hline & 278 & & & 0,43 & não & \\
\hline & 293 & & & 0,72 & não & \\
\hline \multirow{3}{*}{7} & 402 & \multirow{3}{*}{421} & \multirow{3}{*}{19} & 1,00 & não & \multirow{3}{*}{421} \\
\hline & 421 & & & 0,00 & não & \\
\hline & 440 & & & 1,00 & não & \\
\hline \multirow{3}{*}{28} & 642 & \multirow{3}{*}{673} & \multirow{3}{*}{33} & 0,93 & não & \multirow{3}{*}{673} \\
\hline & 669 & & & 0,12 & não & \\
\hline & 708 & & & 1,06 & não & \\
\hline \multirow{3}{*}{90} & 1056 & & \multirow{3}{*}{47} & 0,71 & não & \multirow{3}{*}{1023} \\
\hline & 990 & 1023 & & 0,71 & não & \\
\hline & - & & & - & não & \\
\hline
\end{tabular}


Tabela 4 - Teste de Grubbs - $E_{\text {TAN,50\% }}$ ARC - Energia Intermediária.

\begin{tabular}{|c|c|c|c|c|c|c|}
\hline $\begin{array}{l}\text { Tempo } \\
\text { (Dias) }\end{array}$ & $\begin{array}{c}\mathrm{E}_{\mathrm{TAN}, 50 \%} \\
(\mathrm{MPa})\end{array}$ & $\begin{array}{l}\text { Média } \\
\text { (MPa) }\end{array}$ & $\begin{array}{l}\text { Desv. } \\
\text { Padrão }\end{array}$ & $\mathbf{G}$ & Outlier & $\begin{array}{l}\text { Nova média } \\
\text { (MPa) }\end{array}$ \\
\hline \multirow{4}{*}{0} & 39 & \multirow{4}{*}{61} & \multirow{4}{*}{17,263} & 1,27 & $\operatorname{sim}$ & \multirow{4}{*}{62} \\
\hline & 64 & & & 0,17 & não & \\
\hline & 60 & & & 0,06 & não & \\
\hline & 81 & & & 1,16 & $\operatorname{sim}$ & \\
\hline \multirow{3}{*}{3} & 79 & \multirow{3}{*}{68} & \multirow{3}{*}{22,279} & 0,51 & não & \multirow{3}{*}{81} \\
\hline & 42 & & & 1,15 & $\operatorname{sim}$ & \\
\hline & 82 & & & 0,64 & não & \\
\hline \multirow{3}{*}{7} & 92 & \multirow{3}{*}{96} & \multirow{3}{*}{4,041} & 1,07 & não & \multirow{3}{*}{96} \\
\hline & 100 & & & 0,91 & não & \\
\hline & 97 & & & 0,16 & não & \\
\hline \multirow{3}{*}{28} & 114 & \multirow{3}{*}{119} & \multirow{3}{*}{5,568} & 0,90 & não & \multirow{3}{*}{116} \\
\hline & 118 & & & 0,18 & não & \\
\hline & 125 & & & 1,08 & não & \\
\hline \multirow{3}{*}{90} & 157 & \multirow{3}{*}{166} & \multirow{3}{*}{12,728} & 0,71 & não & \multirow{3}{*}{166} \\
\hline & 175 & & & 0,71 & não & \\
\hline & - & & & - & - & \\
\hline
\end{tabular}

Tabela 5 - Teste de Grubbs - RCS - Solo e ARC-solo - Energia modificada.

\begin{tabular}{|c|c|c|c|c|c|c|}
\hline Material & $\begin{array}{l}\mathrm{RCS} \\
(\mathrm{kPa})\end{array}$ & $\begin{array}{c}\text { Média } \\
(\mathrm{kPa})\end{array}$ & Desv. Padrão & G & Outlier & $\begin{array}{l}\text { Nova média } \\
\quad(\mathrm{kPa})\end{array}$ \\
\hline & 931 & & & 0,71 & não & \\
\hline Solo & $\begin{array}{c}965 \\
*\end{array}$ & 948 & 24,042 & 0,71 & não & 948 \\
\hline $\begin{array}{l}\text { ARC- } \\
\text { solo }\end{array}$ & $\begin{array}{c}271 \\
331 \\
*\end{array}$ & 301 & 42,426 & $\begin{array}{c}0,71 \\
0,71 \\
-\end{array}$ & $\begin{array}{l}\text { não } \\
\text { não } \\
\text { não }\end{array}$ & 301 \\
\hline
\end{tabular}

${ }^{*}$ Os corpos-de-prova apresentaram problemas durante a moldagem.

Tabela 6 - Teste de Grubbs - RCS - Solo e ARC-solo - Energia modificada.

\begin{tabular}{|c|c|c|c|c|c|c|}
\hline Material & $\begin{array}{c}E_{\text {TAN,50\% }} \\
\text { (MPa) }\end{array}$ & $\begin{array}{l}\text { Média } \\
(\mathrm{MPa})\end{array}$ & Desv. Padrão & G & Outlier & $\begin{array}{l}\text { Nova média } \\
\quad(\mathrm{MPa})\end{array}$ \\
\hline & 664 & & & 0,17 & não & \\
\hline Solo & $\begin{array}{c}596 \\
*\end{array}$ & 630 & 48,08 & $\begin{array}{c}0,06 \\
-\end{array}$ & $\begin{array}{l}\text { não } \\
\text { não }\end{array}$ & 630 \\
\hline $\begin{array}{l}\text { ARC- } \\
\text { solo }\end{array}$ & $\begin{array}{c}134 \\
105 \\
*\end{array}$ & 120 & 20,51 & $\begin{array}{c}0,71 \\
0,71 \\
-\end{array}$ & $\begin{array}{l}\text { não } \\
\text { não } \\
\text { não }\end{array}$ & 120 \\
\hline
\end{tabular}

${ }^{*}$ Os corpos-de-prova apresentaram problemas durante a moldagem. 


\section{ANEXO III - COMPRESSÃO DIAMETRAL}

Tabela 1 - Teste de Grubbs - RCTD - ARC - Energia Modificada.

\begin{tabular}{ccccccc}
\hline $\begin{array}{c}\text { Tempo } \\
\text { (Dias) }\end{array}$ & $\mathbf{R T}(\mathbf{k P a})$ & $\begin{array}{c}\text { Média } \\
\mathbf{( k P a )}\end{array}$ & $\begin{array}{c}\text { Desv. } \\
\text { Padrão }\end{array}$ & $\mathbf{G}$ & Outlier & $\begin{array}{c}\text { Nova média } \\
\mathbf{( k P a )}\end{array}$ \\
& 4 & & & 1,15 & sim & \\
$\mathbf{0}$ & 6 & 5 & 1,06 & 0,58 & não & $\mathbf{6}$ \\
& 6 & & & 0,58 & não & \\
\hline \multirow{2}{*}{$\mathbf{3}$} & 9 & & & 0,58 & não & \\
& 9 & 8 & 2,13 & 0,58 & não & $\mathbf{9}$ \\
& 6 & & & 1,15 & sim & \\
\hline \multirow{2}{*}{$\mathbf{7}$} & 11 & & & 0,00 & não & \\
& 13 & 11 & 1,84 & 1,00 & não & $\mathbf{1 1}$ \\
& 9 & & & 1,00 & não & \\
\hline \multirow{2}{*}{$\mathbf{2 8}$} & 18 & & & 1,00 & não & \\
& 11 & 15 & 3,68 & 1,00 & não & $\mathbf{1 5}$ \\
& 15 & & & 0,00 & não & \\
\hline
\end{tabular}

Tabela 2 - Teste de Grubbs - RCTD - ARC - Energia Intermediária

\begin{tabular}{ccccccc}
\hline $\begin{array}{c}\text { Tempo } \\
\text { (Dias) }\end{array}$ & $\mathbf{R T}(\mathbf{k P a})$ & $\begin{array}{c}\text { Média } \\
\mathbf{( k P a )}\end{array}$ & $\begin{array}{c}\text { Desv. } \\
\text { Padrão }\end{array}$ & $\mathbf{G}$ & Outlier & $\begin{array}{c}\text { Nova média } \\
\mathbf{( k P a )}\end{array}$ \\
\hline \multirow{2}{*}{$\mathbf{0}$} & $\theta$ & & & 1,15 & sim & \\
& 2 & 1 & 1,06 & 0,58 & não & $\mathbf{2}$ \\
& 2 & & & 0,58 & não & \\
\hline \multirow{2}{*}{$\mathbf{3}$} & 2 & & & 0,18 & não & \\
& 0 & 3 & 2,80 & 0,90 & não & $\mathbf{3}$ \\
& 6 & & & 1,08 & não & \\
\hline \multirow{2}{*}{$\mathbf{7}$} & 7 & & & 0,00 & não & \\
& 6 & 7 & 1,84 & 1,00 & não & $\mathbf{7}$ \\
& 9 & & & 1,00 & não & \\
\hline \multirow{2}{*}{$\mathbf{2 8}$} & 11 & & & 0,00 & não & \\
& 9 & 11 & 2,00 & 1,00 & não & $\mathbf{1 1}$ \\
& 13 & & & 1,00 & não & \\
\hline
\end{tabular}


Tabela 3 - Teste de Grubbs - RCTD - ARC-solo, solo e ag. natural - Modificada.

\begin{tabular}{|c|c|c|c|c|c|c|}
\hline Material & $R T(k P a)$ & $\begin{array}{l}\text { Média } \\
\text { (kPa) }\end{array}$ & $\begin{array}{l}\text { Desv. } \\
\text { Padrão }\end{array}$ & G & Outlier & $\begin{array}{c}\text { Nova média } \\
\text { (kPa) }\end{array}$ \\
\hline \multirow{3}{*}{$\begin{array}{l}\text { ARC- } \\
\text { SOLO }\end{array}$} & 9 & & & 0,00 & não & \multirow{3}{*}{9} \\
\hline & 6 & 9 & 3,68 & 1,00 & não & \\
\hline & 13 & & & 1,00 & não & \\
\hline \multirow{3}{*}{ SOLO } & 126 & & & 0,43 & não & \multirow{3}{*}{118} \\
\hline & 99 & 118 & 16,88 & 1,14 & não & \\
\hline & 130 & & & 0,71 & não & \\
\hline \multirow{3}{*}{$\begin{array}{c}\text { Ag. } \\
\text { Natural }\end{array}$} & 0 & & & - & não & \multirow{3}{*}{0} \\
\hline & 0 & 0 & 0,00 & - & não & \\
\hline & 0 & & & - & não & \\
\hline
\end{tabular}

